Prepared in cooperation with the

West Virginia Department of Environmental Protection, Division of Water and Waste Management

\title{
Water Quality of Groundwater and Stream Base Flow in the Marcellus Shale Gas Field of the Monongahela River Basin,
} West Virginia, 2011-12

Scientific Investigations Report 2014-5233

Version 1.1, June 2015 
Cover. The extent of the Marcellus Shale in West Virginia and the location of the Monongahela River Basin and its major streams. See figure 1 for an explanation of the extent of the Marcellus Shale. Marcellus Shale thickness from Schwietering and Bocan (2011). 


\section{Water Quality of Groundwater and Stream Base Flow in the Marcellus Shale Gas Field of the Monongahela River Basin, West Virginia, 2011-12}

By Douglas B. Chambers, Mark D. Kozar, Terence Messinger, Michon L. Mulder, Adam J. Pelak, and Jeremy S. White

Prepared in cooperation with the

West Virginia Department of Environmental Protection, Division of Water and Waste Management

Scientific Investigations Report 2014-5233

Version 1.1, June 2015 


\title{
U.S. Department of the Interior SALLY JEWELL, Secretary
}

\section{U.S. Geological Survey Suzette M. Kimball, Acting Director}

\author{
U.S. Geological Survey, Reston, Virginia: \\ First release: 2015, online and in print \\ Revised: June 2015 (ver. 1.1), online and in print
}

\begin{abstract}
For more information on the USGS - the Federal source for science about the Earth, its natural and living resources, natural hazards, and the environment, visit http://www.usgs.gov or call 1-888-ASK-USGS.

For an overview of USGS information products, including maps, imagery, and publications, visit http://www.usgs.gov/pubprod
\end{abstract}

\begin{abstract}
Any use of trade, firm, or product names is for descriptive purposes only and does not imply endorsement by the U.S. Government.

Although this information product, for the most part, is in the public domain, it also may contain copyrighted materials as noted in the text. Permission to reproduce copyrighted items must be secured from the copyright owner.
\end{abstract}

Suggested citation:

Chambers, D.B., Kozar, M.D., Messinger, Terence, Mulder, M.L., Pelak, A.J., and White, J.S., 2015, Water quality of groundwater and stream base flow in the Marcellus Shale Gas Field of the Monongahela River Basin, West Virginia, 2011-12 (ver. 1.1, June 25, 2015): U.S. Geological Survey Scientific Investigations Report 2014-5233, 75 p., http://dx.doi.org/10.3133/sir20145233.

ISSN 2328-031X (printed) ISSN 2328-0328 (online) 


\section{Acknowledgments}

The authors thank Katherine S. Paybins, Jessica L. Wood, and Hugh E. Bevans of the U.S. Geological Survey (USGS) for helping with the collection of samples during the groundwater survey and base-flow survey. Thanks also go to Jeffrey E. Bailey, West Virginia Department of Environmental Protection, Division of Water and Waste Management, for assistance in understanding land-use patterns in the study area and in surface-water site selection. Lisa Senior and Michael Bradley of the USGS are thanked for their thoughtful reviews that have improved this report. 


\section{Contents}

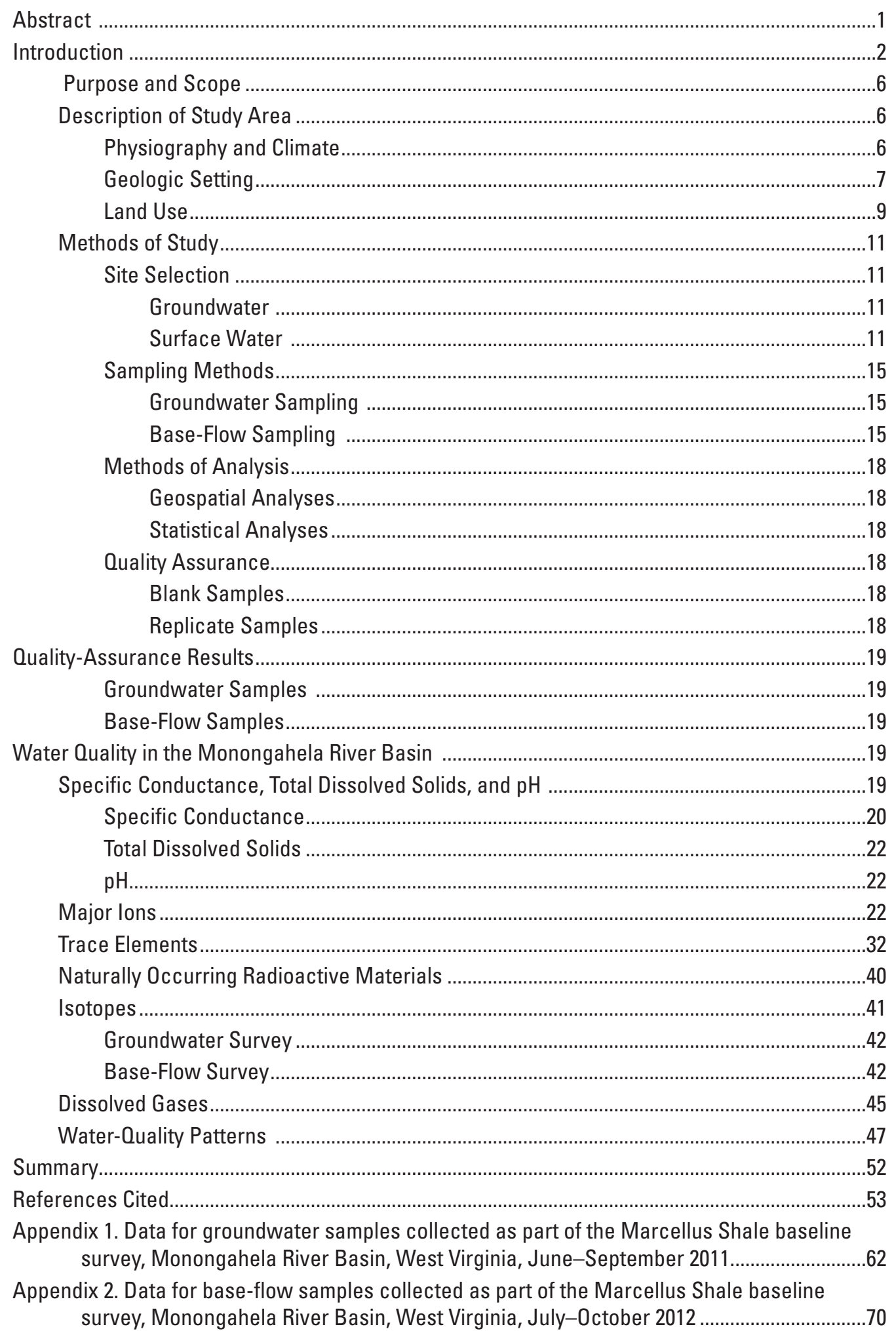




\section{Figures}

1. Map showing extent of the Marcellus Shale in the Monongahela River Basin in West Virginia

2. Maps showing $A$, thickness of the Marcellus Shale, wells completed in the Marcellus Shale, and horizontal wells, and $B$, locations of all gas wells, including abandoned wells, Monongahela River Basin and vicinity, West Virginia, 2012.

3. Geologic map of the Monongahela River Basin in West Virginia

4. Map showing coal mines in the Monongahela River Basin and adjacent areas in West Virginia

5. Map showing groundwater survey sites in the Monongahela River Basin, West Virginia, June-September 2011

6. Flow chart showing the process for stratifying stream-water sampling sites

7. Map showing streams, stream sampling sites, gas wells completed in the Marcellus Shale through 2012 showing gas production through 2010, and average thickness of the Marcellus Shale by HUC-12

8. Boxplots showing distribution of specific conductance for samples collected as part of the Marcellus Shale baseline study, 2011-12, and historical specific conductance for samples collected in the Monongahela River Basin, West Virginia: $A$, groundwater samples and $B$, base-flow samples.

9. Boxplots showing distribution of specific conductance for samples collected as part of the Marcellus Shale baseline study, Monongahela River Basin, West Virginia, 2011-12, grouped by gas production type: $A$, groundwater samples and $B$, base-flow samples.

10. Boxplots showing distribution of $\mathrm{pH}$ in samples collected as part of the Marcellus Shale baseline study, 2011-12, and historical pH in samples from the Monongahela River Basin, West Virginia: $A$, groundwater samples and $B$, base-flow samples.

11. Boxplots showing distribution of $\mathrm{pH}$ in samples collected as part of the Marcellus Shale baseline study in the Monongahela River Basin, West Virginia, 2011-12: $A$, groundwater samples and $B$, base-flow samples.

12. Piper diagrams showing major ion composition of samples collected as part of the Marcellus Shale baseline study, 2011-12, from the Monongahela River Basin, West Virginia: $A$, groundwater survey samples classified by geologic formation and $B$, base-flow survey samples.

13. Boxplots showing distribution of major-ion concentrations in groundwater and base-flow samples collected as part of the Marcellus Shale baseline study, 2011-12, and historical major-ion concentrations, Monongahela River Basin, West Virginia: $A$, calcium, $B$, sodium, $C$, magnesium, $D$, potassium, $E$, chloride, $F$, sulfate, $G$, bromide, and $H$, fluoride .

14. Boxplots showing distribution of major-ion concentrations in groundwater and base-flow samples collected as part of the baseline study, Monongahela River Basin, West Virginia, 2011-12, grouped by gas production bin: $A$, calcium, $B$, sodium, $C$, magnesium, $D$, potassium, $E$, chloride, $F$, sulfate, $G$, bromide, and $H$, fluoride

15. Boxplots showing distribution of trace-element concentrations in groundwater and base-flow samples collected as part of the Marcellus Shale baseline study, 2011-12, and historical trace-element concentrations, Monongahela River Basin, West Virginia: $A$, aluminum, $B$, iron, $C$, manganese, $D$, barium, and $E$, strontium in base flow only. 
16. Boxplots showing distribution of trace-element concentrations in groundwater and base-flow samples collected as part of the baseline study, 2011-12, Monongahela River Basin, West Virginia, grouped by gas production bin: $A$, aluminum, $B$, iron, $C$, manganese, $D$, barium, $E$, strontium, $F$, cobalt, $G$, molybdenum, and $H$, arsenic

17. Boxplots showing distribution of uranium concentrations in groundwater and base-flow samples collected as part of the Marcellus Shale baseline study, Monongahela River Basin, West Virginia, 2011-12, grouped by gas production bin: $A$, groundwater samples and $B$, base-flow samples .

18. Graphs showing oxygen and hydrogen isotopic composition of water in $A$, groundwater samples and $B$, base-flow samples collected as part of the Marcellus Shale baseline study in the Monongahela River Basin, West Virginia, 2011-12, and the Global Meteoric Water Line.

19. Graphs showing isotopic signatures of dissolved methane in 11 groundwater samples collected as part of the Marcellus Shale baseline study, Monongahela River Basin, West Virginia, 2011, in samples from the Pittsburgh Coal, in a Marcellus Shale gas separation tank, and in various other sources: $A$, deep, microbially stimulated methane; $B$, biogenic, thermogenic, and mixed source methane; and $C$, predominantly thermogenic methane signature.

20. Graph showing isotopic composition of dissolved inorganic carbon in base-flow samples collected as part of the Marcellus Shale baseline study, Monongahela River Basin, West Virginia, 2012.

21. Graph showing concentrations of dissolved nitrogen in relation to concentrations of dissolved argon in samples from 39 wells and 2 springs collected as part of the baseline study, Monongahela River Basin, West Virginia, 2011, with associated estimates of recharge temperature and excess air, based on normalized sea-level concentrations

22. Diagram showing principal component axis scores for the two principal components for selected groundwater samples collected as part of the Marcellus Shale baseline study, Monongahela River Basin, West Virginia, 2011

23. Map showing concentrations of methane in groundwater samples collected as part of the Marcellus Shale baseline study, Monongahela River Basin, West Virginia, 2011, and the location of mined coal seams and geologic structural features.

24. Graphs showing concentration of constituent or property in relation to the mining intensity, measured as the sum of mined areas in the 12-digit hydrologic unit code areas, expressed as a proportion of the HUC-12 surface area for $A$, sulfate and $B$, specific conductance in base-flow samples collected as part of the Marcellus Shale baseline survey, Monongahela River Basin, West Virginia, 2012 


\section{Tables}

1. Water-quality properties, major ions, trace elements, naturally occurring radioactive materials, and dissolved gases analyzed for in groundwater and surface-water samples from the Marcellus Shale baseline survey, Monongahela River Basin, West Virginia, 2011-12..

2. Site information for wells and springs sampled for the groundwater survey as part of the Marcellus Shale baseline survey, Monongahela River Basin, West Virginia, June-September 2011

3. Site information for streams sampled during base flow as part of the Marcellus Shale baseline survey, Monongahela River Basin, West Virginia, July-October 2012

4. Statistical summary of water-quality field measurements and major ions in samples collected for the groundwater survey and base-flow survey as part of the Marcellus Shale baseline survey, Monongahela River Basin, West Virginia, 2011-12

5. Statistical summary of trace elements in samples collected for the groundwater survey and the base-flow survey as part of the Marcellus Shale baseline survey, West Virginia, 2011-12

6. Statistical summary of naturally occurring radioactive materials in groundwater and base-flow samples collected as part of the Marcellus Shale baseline survey, Monongahela River Basin, West Virginia, 2011-12.

7. Statistical summary of dissolved gases in groundwater samples collected as part of the Marcellus Shale baseline survey, Monongahela River Basin, West Virginia, 2011

8. Principal component loadings from analysis of 23 variables potentially affecting groundwater quality in the Monongahela River Basin in West Virginia, 2011 . 


\section{Conversion Factors}

Inch/Pound to SI

\begin{tabular}{|c|c|c|}
\hline Multiply & By & To obtain \\
\hline \multicolumn{3}{|c|}{ Length } \\
\hline foot $(\mathrm{ft})$ & 0.3048 & meter $(\mathrm{m})$ \\
\hline mile (mi) & 1.609 & kilometer $(\mathrm{km})$ \\
\hline \multicolumn{3}{|c|}{ Area } \\
\hline square mile $\left(\mathrm{mi}^{2}\right)$ & 259.0 & hectare (ha) \\
\hline square mile $\left(\mathrm{mi}^{2}\right)$ & 2.590 & square kilometer $\left(\mathrm{km}^{2}\right)$ \\
\hline \multicolumn{3}{|c|}{ Volume } \\
\hline $\begin{array}{l}\text { barrel (bbl), (petroleum, } \\
1 \text { barrel=42 gal) }\end{array}$ & 0.1590 & cubic meter $\left(\mathrm{m}^{3}\right)$ \\
\hline gallon (gal) & 3.785 & liter $(\mathrm{L})$ \\
\hline gallon (gal) & 0.003785 & cubic meter $\left(\mathrm{m}^{3}\right)$ \\
\hline gallon (gal) & 3.785 & cubic decimeter $\left(\mathrm{dm}^{3}\right)$ \\
\hline million gallons (Mgal) & 3,785 & cubic meter $\left(\mathrm{m}^{3}\right)$ \\
\hline cubic foot $\left(\mathrm{ft}^{3}\right)$ & 28.32 & cubic decimeter $\left(\mathrm{dm}^{3}\right)$ \\
\hline cubic foot $\left(\mathrm{ft}^{3}\right)$ & 0.02832 & cubic meter $\left(\mathrm{m}^{3}\right)$ \\
\hline thousand cubic feet (Mcf) & 28.32 & cubic meter $\left(\mathrm{m}^{3}\right)$ \\
\hline \multicolumn{3}{|c|}{ Flow rate } \\
\hline cubic foot per second $\left(\mathrm{ft}^{3} / \mathrm{s}\right)$ & 0.02832 & cubic meter per second $\left(\mathrm{m}^{3} / \mathrm{s}\right)$ \\
\hline $\begin{array}{l}\text { cubic foot per second per square } \\
\text { mile }\left[\left(\mathrm{ft}^{3} / \mathrm{s}\right) / \mathrm{mi}^{2}\right]\end{array}$ & 0.01093 & $\begin{array}{l}\text { cubic meter per second per } \\
\text { square kilometer }\left[\left(\mathrm{m}^{3} / \mathrm{s}\right) / \mathrm{km}^{2}\right]\end{array}$ \\
\hline \multicolumn{3}{|c|}{ Pressure } \\
\hline atmosphere, standard (atm) & 101.3 & kilopascal $(\mathrm{kPa})$ \\
\hline Bar & 100 & kilopascal $(\mathrm{kPa})$ \\
\hline inch of mercury at $60^{\circ} \mathrm{F}$ (in $\mathrm{Hg}$ ) & 3.377 & kilopascal $(\mathrm{kPa})$ \\
\hline \multicolumn{3}{|c|}{ Radioactivity } \\
\hline picocurie per liter $(\mathrm{pCi} / \mathrm{L})$ & 0.037 & becquerel per liter $(\mathrm{Bq} / \mathrm{L})$ \\
\hline
\end{tabular}

Temperature in degrees Celsius $\left({ }^{\circ} \mathrm{C}\right)$ may be converted to degrees Fahrenheit $\left({ }^{\circ} \mathrm{F}\right)$ as follows:

${ }^{\circ} \mathrm{F}=\left(1.8 x^{\circ} \mathrm{C}\right)+32$

Temperature in degrees Fahrenheit $\left({ }^{\circ} \mathrm{F}\right)$ may be converted to degrees Celsius $\left({ }^{\circ} \mathrm{C}\right)$ as follows:

${ }^{\circ} \mathrm{C}=\left({ }^{\circ} \mathrm{F}-32\right) / 1.8$

Vertical coordinate information is referenced to the North American Vertical Datum of 1988 (NAVD 88).

Horizontal coordinate information is referenced to the North American Datum of 1983 (NAD 83).

Elevation, as used in this report, refers to distance above the vertical datum.

Specific conductance is given in microsiemens per centimeter at 25 degrees Celsius $(\mu \mathrm{S} / \mathrm{cm}$ at $\left.25^{\circ} \mathrm{C}\right)$.

Concentrations of chemical constituents in water are given either in milligrams per liter (mg/L) or micrograms per liter ( $\mu \mathrm{g} / \mathrm{L})$.

Radioactivity of chemical constituents in water are given in picocuries per liter (pCi/L). 


\title{
Water quality of groundwater and stream base flow in the Marcellus Shale Gas Field of the Monongahela River Basin, West Virginia, 2011-12
}

\author{
By Douglas B. Chambers, Mark D. Kozar, Terence Messinger, Michon L. Mulder ${ }^{1}$, Adam J. Pelak', \\ and Jeremy S. White
}

\section{Abstract}

The Marcellus Shale gas field underlies portions of New York, Pennsylvania, Ohio, Virginia, Maryland, Tennessee, and West Virginia. Development of hydraulic fracturing and horizontal drilling technology led to extensive development of gas from the Marcellus Shale beginning about 2007. The need to identify and monitor changes in water-quality conditions related to development of the Marcellus Shale gas field prompted the U.S. Geological Survey, in cooperation with the West Virginia Department of Environmental Protection, Division of Water and Waste Management, to document water quality for comparison with water quality in samples collected at a future date. The identification of change in water-quality conditions over time is more difficult if baseline water-quality conditions have not been documented.

U.S. Geological Survey personnel sampled groundwater and surface water in West Virginia's Monongahela River Basin during 2011-12. A groundwater survey, in which 39 wells and 2 springs were sampled, was conducted during June through September 2011. A base-flow survey was conducted during July through October 2012; 50 stream sites were sampled under base-flow conditions in this survey.

Because additives to hydraulic fracturing fluids are variable and decrease in flowback water over a relatively short time, water-quality analyses for this study focused on documenting the water-quality characteristics typical of water from shallow aquifers; water derived from contact with the Marcellus Shale (flowback from hydraulic fracturing or formation water); and water with constituents from conventional oil and gas development, sewage effluent, and coal-mine drainage. All samples were analyzed for field properties (water temperature, $\mathrm{pH}$, specific conductance, dissolved oxygen, and turbidity), major ions, trace elements, naturally occurring radioactive materials, and stable isotopes.

${ }^{1}$ West Virginia University.
In addition to documenting baseline water-quality conditions for an area of shale-gas development, these data were examined for patterns in water quality. Groundwater and base-flow survey data were compared to historical data from the Monongahela River Basin in West Virginia. Additionally, groundwater- and base-flow survey samples were grouped by Marcellus Shale gas production in the subbasin in which that sampling site was located.

The comparisons of data collected as part of this study with historical data identified few differences. No significant difference was found in a comparison of groundwater survey data and historical data. Base-flow survey samples differed significantly from historical data for $\mathrm{pH}$, chloride, and strontium, all of which had higher concentrations in the base-flow survey samples. Differences in $\mathrm{pH}$ are likely related to changes in mining regulation beginning in 1977. Concentrations of chloride and strontium elevated above background concentrations may be related to saline groundwater; saline water is within 300 feet of the land surface in parts of the study area.

In the comparison of base-flow survey samples grouped by shale-gas-production setting, significant differences were found for fluoride and barium. Concentrations of fluoride and barium were higher in stream subbasins with active Marcellus Shale production than in subbasins not near active Marcellus Shale production. Elevated fluoride and barium are associated with deep brines.

Generally, naturally occurring radioactive materials were not found in elevated concentrations in either groundwater or base-flow samples. Only 3 samples, 2 from the groundwater survey and one from the base-flow survey, exceeded the U.S. Environmental Protection Agency maximum contaminant level for radium isotopes of 5.0 picocurie per liter for either a single isotope or a combined value of radium-226 and radium-228.

Stable isotope composition indicates broad similarity among surface water, shallow groundwater, and precipitation in the region. Neither shallow groundwater nor surface water 
showed a marked similarity with the deep brines associated with shale gas. In most of the groundwater survey samples, 38 of 41 samples, dissolved gas profiles were similar to those previously found in samples from shallow, domestic wells in the region.

This study provides a baseline of water-quality conditions in the Monongahela River Basin in West Virginia during the early phases of development of the Marcellus Shale gas field. Although not all inclusive, the results of this study provide a set of reliable water-quality data against which future data sets can be compared and the effects of shale-gas development may be determined.

\section{Introduction}

Natural gas in West Virginia was reported as early as 1774, followed by the first documented industrial use in the State, fueling brine boilers, in 1841 (White, 1904). Since that time, natural gas has been an integral component of West Virginia's and the Nation's energy supply. Since about 2007, the development of hydraulic fracturing and horizontal drilling technology has led to extensive development of gas from the Marcellus Shale in the Monongahela River Basin in West Virginia (figs. 1 and 2).

Much of Nation's historical gas production has been from "conventional" gas fields, geographically discrete accumulations with distinct water-hydrocarbon contacts (Schenk and Pollastro, 2002). The localized nature, high permeability, and high recovery factors of conventional gas accumulations make them amenable to extraction by vertical drilling. In contrast, shale gas resources form within organic-rich shale source rock (U.S. Energy Information Administration, 2012). The low permeability of the shale greatly inhibits the gas from migrating to more permeable reservoir rocks. Although some shale formations have long been known to be rich in gas, little gas could be obtained from them using conventional drilling techniques. Improvements in drilling technologies, specifically horizontal drilling and hydraulic fracturing, have made recovery of shale-gas reserves economically feasible.

The Marcellus Shale is a formation of Devonian age that underlies large parts of New York, Pennsylvania, Ohio, and West Virginia, and smaller parts of Virginia, Maryland, and Tennessee. The Marcellus Shale ranges in depth from about 2,000 feet below mean sea level (MSL) along the western edge of its extent to greater than 6,000 feet below MSL along the eastern edge, with the thicker deposits occurring at greater depths. A recent assessment estimated that 84,198 billion cubic feet of natural gas and 3,379 million barrels of natural gas liquids are technically recoverable from the Marcellus Shale (Coleman and others, 2011). On the basis of the 2009 consumption of 23 trillion cubic feet $\left(\mathrm{ft}^{3}\right)$, this is enough natural gas to meet the needs of the entire Nation for about 15 years (Coleman and others, 2011).
The low permeability and low recovery factors of Marcellus Shale, as with other shale-gas fields, makes extraction with vertical drilling challenging. However, the use of horizontal, or directional drilling, and hydraulic fracturing allow recovery of natural gas from the Marcellus Shale. Directional drilling and hydraulic fracturing capitalize upon and augment naturally occurring fractures, thereby enhancing permeability and gas recovery (U.S. Department of Energy, 2013).

A horizontal well begins with a vertical well drilled to a depth approaching that of the targeted shale bed, 5,000 to 9,000 feet below MSL in the Marcellus Shale in West Virginia (U.S. Department of Energy, 2013). Once the desired depth of vertical well bore is reached, a steerable downhole motor is used to drill the well at an angle. The steerable motor will eventually impart sufficient angular deviation to turn the well bore 90 degrees from the vertical. The well bore is then extended as a lateral well bore, or "lateral," through the shale bed. These laterals can extend for 3,000 to 10,000 feet from the vertical well bore (U.S. Department of Energy, 2013).

Once the horizontal wells are completed, the recovery of gas from the Marcellus Shale is further enhanced through hydraulic fracturing, commonly referred to as "fracking." Hydraulic fracturing uses fluids under high pressure to create fractures in the rock, increasing gas flow to the well bore. The well casing and cement are perforated with small explosive charges prior to injection of the pressurized fluid. The fluid contains quartz sand or other materials of similar size or shape (proppants) that remain in the newly created fractures to keep them from closing. The hydraulic-fracturing fluid and formation fluid can flow back to land surface as the injection pressure is reduced.

Although natural gas has been promoted as the cleanestburning fossil fuel, emitting only 53 kilograms $(\mathrm{kg})$ of carbon dioxide $\left(\mathrm{CO}_{2}\right)$ per million British thermal units $(\mathrm{Btu})$; coal emits an average of $95 \mathrm{~kg}$ of $\mathrm{CO}_{2}$ per million Btu (U.S. Energy Information Administration, 1999). Production of natural gas is not without environmental consequences. Kappel and others (2013) presented critical water-resources issues associated with shale-gas development in the Appalachian Basin, grouped into the following categories: water supply, stray gas, radioactivity in shale waste, fluid waste treatment and disposal, deep well injection of fluid waste, solid waste disposal, and construction and transportation.

Large quantities of water are used during the hydraulic fracturing, posing potential water-quality issues. As much as 3 million gallons of water can be used for a single hydraulic fracturing treatment. Hydraulic fracturing fluids contain chemicals that increase the viscosity to a gel-like consistency and allow the transport of a proppant, usually sand, into the hydraulically created fractures to keep them open. Other chemicals allow the viscosity of the fluid to break down quickly so that the fluid can be easily removed. In addition to chemical additives in the hydraulic fracturing fluids, the contact of fluids with the rock matrix introduces a variety of formation constituents, including brines, trace elements, and radionuclides. 


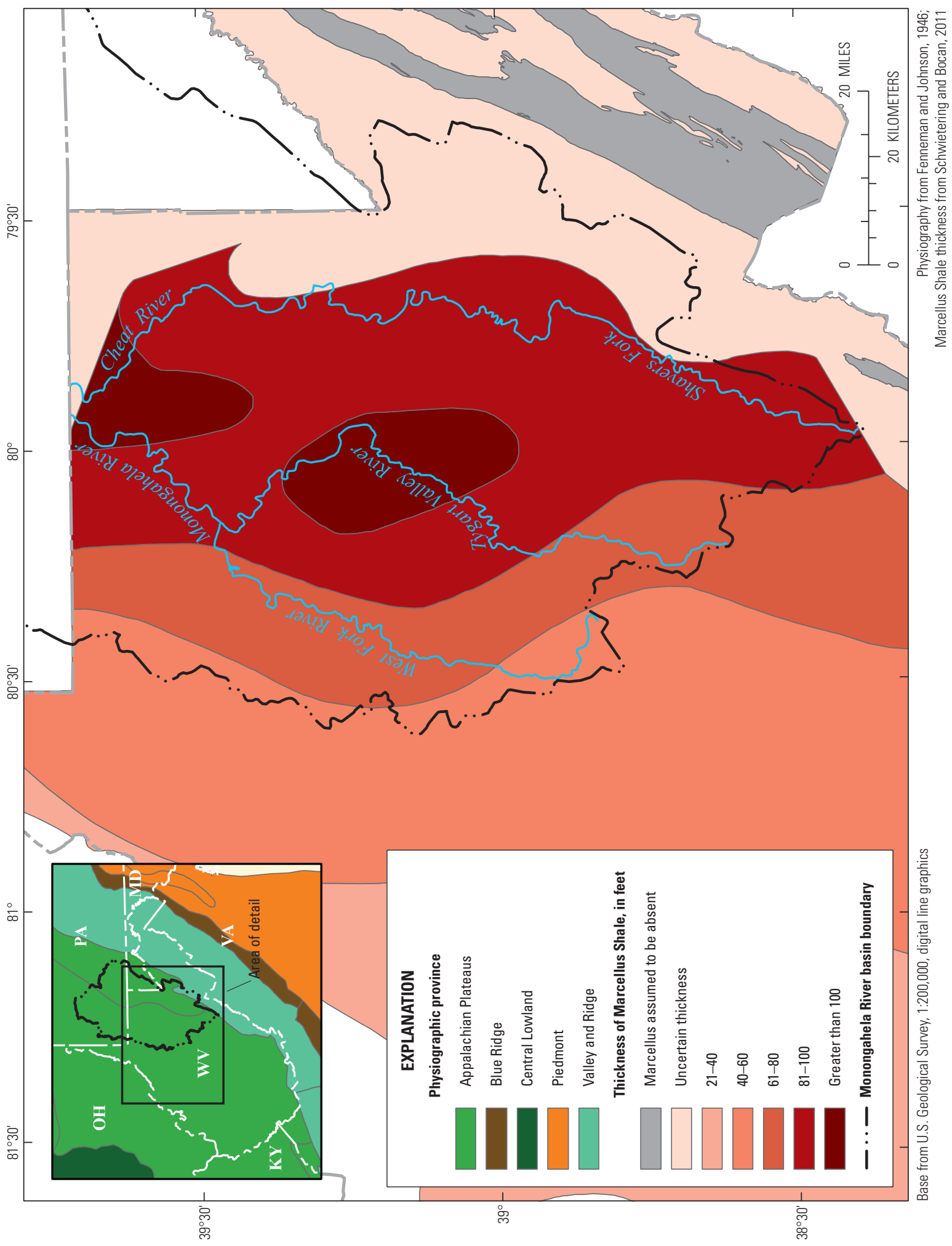

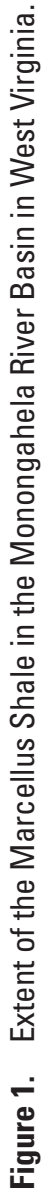




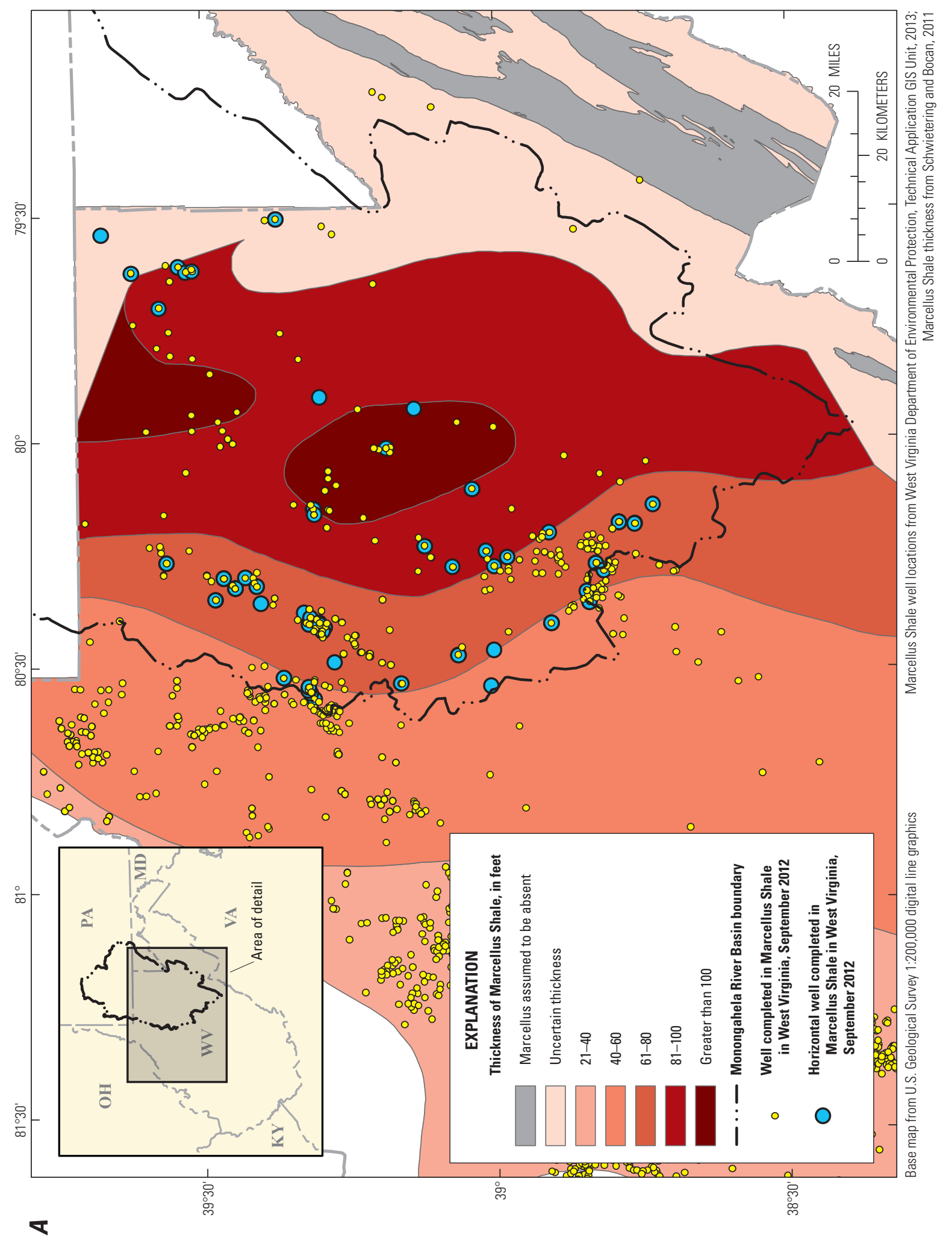

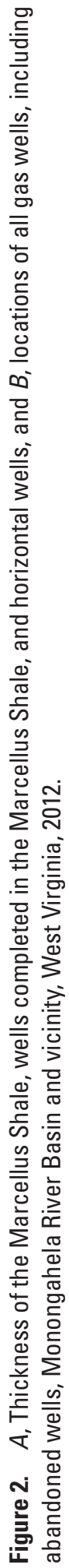




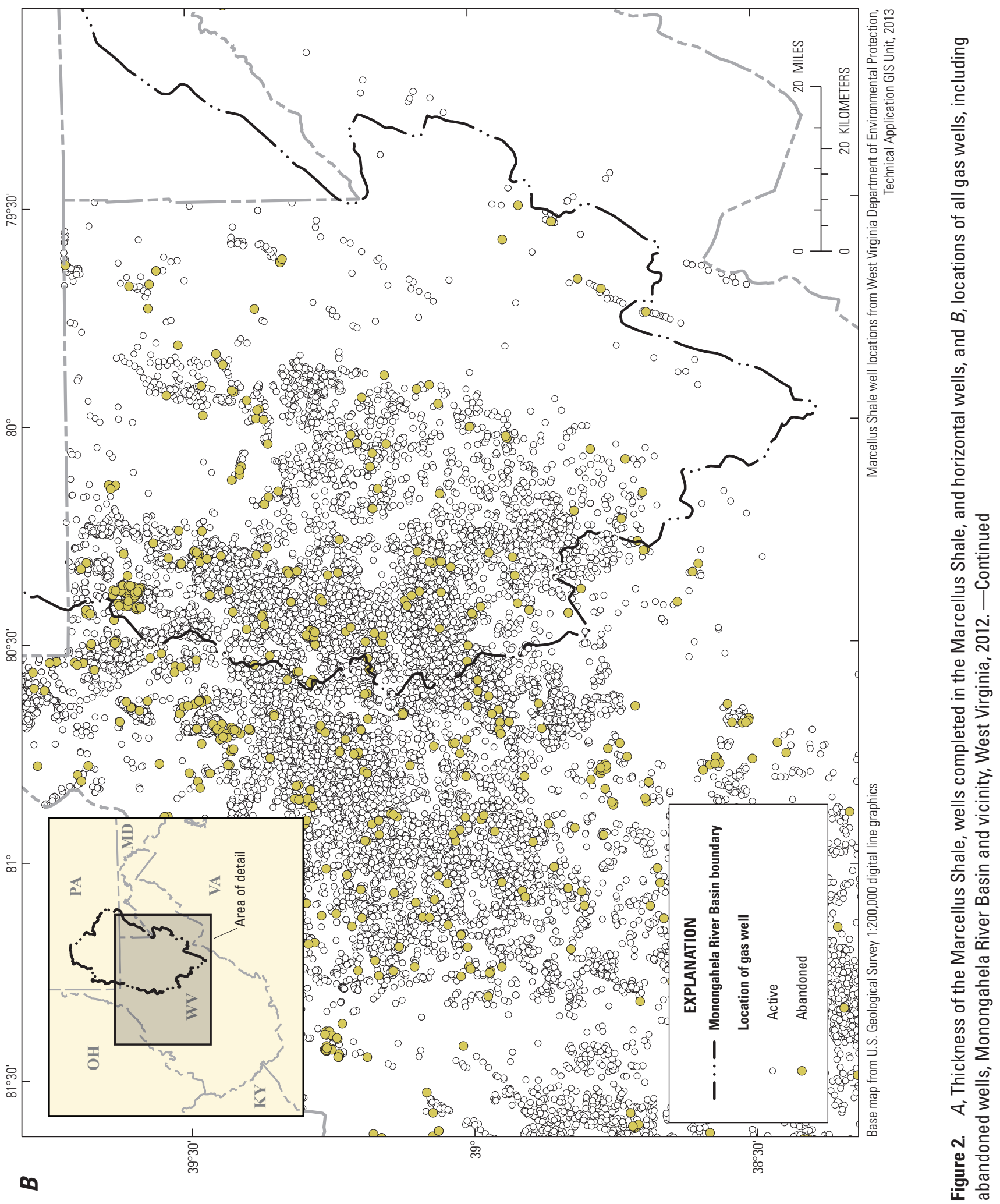


Hydraulic fracturing fluids and formation waters are highly contaminated and must be captured and disposed of properly when the fluids flow back to land surface. Initial recovery of hydraulic fracturing fluids in the Marcellus Shale is 20-25 percent (U.S. Department of Energy, 2013). Industry estimates for continued recovery of hydraulic fracturing fluid and formation water, even after the well is on-line, range from 5 to 50 barrels per week. Current regulations in West Virginia require offsite disposal of fracturing fluids and flowback from horizontal wells (West Virginia Department of Environmental Protection, 2010). Fluids are collected in either a sealed tank or a lined open pit and hauled by truck to a disposal site. The preferred method of disposal (as of 2014) for hydraulic fracturing fluids is underground injection into deep formations (West Virginia Department of Environmental Protection, 2010), often former oil- and gas-producing formations. This disposal practice could also be a threat to water quality because of the potential for spills during the fluid handling and transportation process or leakage from natural faults and fractures or from former gas and oil wells that have not been properly constructed or abandoned.

Documentation of the 2011-12 baseline quality of shallow groundwater underlain by the Marcellus Shale in northcentral West Virginia can be used for comparison with future water quality to monitor and recognize potential water-quality changes from gas-production activities should they occur. The West Virginia's Monongahela River Basin was identified as an area of rapid Marcellus Shale gas development. Therefore, in 2011 the U.S. Geological Survey (USGS), in cooperation with the West Virginia Department of Environmental Protection (WVDEP), Division of Water and Waste Management, began a study to obtain baseline water-quality information for the Monongahela River Basin in West Virginia. The waterquality properties and constituents documented during this study include those that are naturally occurring in the Marcellus Shale and are likely to be elevated in shallow groundwater through contact with return flows or leakage from hydraulic fracturing activities. Because groundwater discharge to streams forms base flow, potential water-quality changes to groundwater may also affect base-flow quality.

\section{Purpose and Scope}

This report describes the water quality of groundwater and stream base flow in that part of north-central West Virginia drained by the Monongahela River during early development of the Marcellus Shale gas field. Groundwater samples were collected during June-September 2011, and base-flow samples were collected in 2012. The conditions described in this report include those affected by human activities that potentially introduce contaminants into surface water and groundwater similar to those expected from shale-gas development. Concentrations of water-quality constituents are presented in figures and tables.

\section{Description of Study Area}

The study area is the Monongahela River Basin in West Virginia (fig. 1) and encompasses a drainage area of 7,377 square miles $\left(\mathrm{mi}^{2}\right)\left(19,106\right.$ square kilometers $\left.\left[\mathrm{km}^{2}\right]\right)$ in the north-central part of West Virginia. Major tributaries to the Monongahela River are the Cheat River, Tygart Valley River, and the West Fork River. The study area was selected because of the large number of vertical and horizontal gas wells that are proposed for the Marcellus Shale.

\section{Physiography and Climate}

The study area is mostly within the Appalachian Plateaus Physiographic Province, but a small area in the southeastern part of the study area has been mapped as lying within the Valley and Ridge Physiographic Province (Fenneman, 1938). The Appalachian Plateaus are characterized by flat to slightly dipping sedimentary rocks that have been eroded by fluvial processes to form a rolling topography with a dendritic stream drainage pattern.

The boundary between the two provinces is known as the Allegheny Front, an abrupt and complex transition between the two physiographic provinces. To the west of the Allegheny Front, lie the relatively flat to slightly dipping rocks of the Appalachian Plateaus; to the east of the Allegheny Front, lie steeply dipping, long linear ridges and valleys of the Valley and Ridge Physiographic Province.

Within the Valley and Ridge, topography varies and is marked by steep ridges, typically formed by more weather resistant sandstones and limestone, and narrow valleys, which tend to form in areas underlain by less resistant shales and siltstones (West Virginia Geological and Economic Survey, 2014b). Orogenic processes compressed rocks to form the Valley and Ridge Physiographic Province. The compressional stress resulted in significant folding and faulting of the bedrock strata, and resulted in the characteristic alternating long linear valleys and ridges from which the province derived its name. Stream drainages in the Valley and Ridge Physiographic Province commonly exhibit a predominantly trellis drainage pattern.

Elevation in the study area ranges from about $790 \mathrm{ft}$ above the North American Vertical Datum of 1988 (NAVD 88) near the Monongahela River at the border of West Virginia and Pennsylvania to about 4,850 $\mathrm{ft}$ in the southern part of the study area. Mean annual precipitation within the Appalachian Plateaus Physiographic Province varies with elevation owing to orographic lifting. Mean annual precipitation (1981-2010) ranged from 44 inches per year (in/yr) to $66 \mathrm{in} / \mathrm{yr}$ (PRISM Climate Group, 2012). Maximum precipitation occurs in the mountains in the southern part of the study area, and minimum precipitation occurs near the Monongahela and West Fork Rivers. 


\section{Geologic Setting}

Geologic strata in the study area are composed of several formations and groups (fig. 3), ranging in age from Devonian through Permian with Quaternary alluvial deposits along the streams and rivers. The strata include parts of geologic formations of Devonian, Mississippian, and Pennsylvanian age, and all bedrock in the study area is sedimentary in origin. Geologic nomenclature used in this report conforms with that used by the West Virginia Geological and Economic Survey, as depicted on the 1968 State geologic map of West Virginia (Cardwell and others, 1968). Bedrock composition of the formations is described below (Cardwell and others, 1968).

Devonian-age geologic strata exposed at land surface in the study area include parts of the Harrell Shale, Brallier Formation, Chemung Group, and the Hampshire Formation (fig. 3). The Harrell Shale and the Brallier Formation are composed predominantly of dark marine shales with thin interspersed lenses of limestone, siltstone, and sandstone. The Chemung Group is characterized as mostly siltstone and sandstone with shale and conglomerate interbeds. The Hampshire Formation is predominantly shale and fine micaceous sandstone, with siltstone, sandstone, and conglomerate. The oldest rocks that crop out in the study area are in the Harrell Shale Formation. The Mahantango Formation, which is composed predominantly of thick laminated marine shale, siltstone, sandstone, and some limestone (Cardwell and others, 1968), does not crop out within the study area, but immediately underlies the Harrell Shale. The Marcellus Shale, which also does not crop out in the study area but is the primary emphasis of this study, underlies the Mahantango Formation and is composed of predominantly gray black to black thinly laminated pyritic shales (Cardwell and others, 1968).

Mississippian-age strata include parts of the Price Formation, the Greenbrier Group, and the Bluefield, Hinton, Princeton Sandstone, and Bluestone Formations (fig. 3). The Price Formation is composed predominantly of hard massive sandstones with some shale. The Price Formation was previously referred to as the Pocono Group but was later revised as a result of additional stratigraphic studies. Some older geologic maps, as well as the USGS National Water Information System (NWIS) database still refer to the Price Formation as the Pocono Group. The Greenbrier Group is composed of massive marine limestones with associated shales and minor sandstone beds. Outside the study area, the Greenbrier Group is one of the more prominent karst regions in West Virginia. The Bluefield and Hinton Formations are composed of shale and sandstone with minor interbeds of limestone. The Bluestone Formation and Princeton Sandstone are composed predominantly of shale and sandstone. The Bluefield, Hinton, and Bluestone Formations, and the Princeton Sandstone, are thin exposures in the outcrop and are commonly collectively referred to, and shown on the accompanying geologic map (fig. 3), as the Mauch Chunk Group.
Pennsylvanian-age strata within the study area include important coal seams, such as the Pittsburgh, Freeport, Kittanning, and Sewickley seams. Pennsylvanian-age strata in the study area include parts of the New River Formation, Kanawha Formation, Allegheny Formation, Conemaugh Group, Monongahela Group, and the Dunkard Group (fig. 3). In the northeast part of the study area the depositional sequence thins, and the Pocahontas, New River, and Kanawha Formations are collectively referred to as the Pottsville Group (fig. 3). The Pottsville Group is composed of sandstones and some conglomerate with thin shales and coal seams. Where the New River and Kanawha Formations crop out in sufficient area, they are mapped separately from the Pottsville Group (fig. 3). The New River and Kanawha Formations are composed of sandstone with some shale, siltstone, and coal. The Allegheny Formation is composed of cyclic sequences of sandstone, siltstone, shale, limestone, and coal. The more economically relevant coal seams in the Allegheny Formation are the Freeport, Kittanning, and Clarion coal seams. The Conemaugh Group is composed of cyclic sequences of shale, siltstone, sandstone, thin limestones, and coal. Economically important coal seams in the Conemaugh Group are the Bakerstown, Brush Creek, and Mahoning coal seams. The Monongahela Group is also composed predominantly of sandstone, siltstone, shale, limestone, and coal. Economically important coal seams in the Monongahela Group are the Pittsburgh, Sewickley, Uniontown, Waynesburg, and Redstone coal seams.

There is debate about the geologic age of the Dunkard Group, but it occurs either at the top of the stratigraphic sequence of Pennsylvanian strata or at the base of Permian strata. The Dunkard Group is composed of sandstone, siltstone, shale, limestone, and coal similar to that of most of the Pennsylvanian-age strata. Economically important coal seams in the Dunkard Group are the Washington and Waynesburg A coal seams.

Because this report presents baseline water-quality conditions in the Marcellus Shale gas field of the Monongahela River Basin in West Virginia, and because the Marcellus Shale does not crop out in the study area, a discussion of the depth of burial of the Marcellus Shale within the study area is warranted. The USGS recently published geologic cross sections that encompass the study area (Ryder and others, 2008; 2009). On the basis of these cross sections, the depth to the Marcellus Shale may be inferred. The Marcellus Shale ranges in depth from approximately 7,100 feet below land surface (bls) in Marion County, West Virginia, where rocks are slightly dipping, to 4,200 feet bls along the crest of the Deer Park-Leadmine anticline in Preston County, and to only 1,400 feet bls along the crest of the Elkins Valley Anticline in Randolph County, West Virginia, based on the geologic cross sections. The geologic cross sections indicate that thrust faults cut through the Marcellus Shale and extend to the surface. 


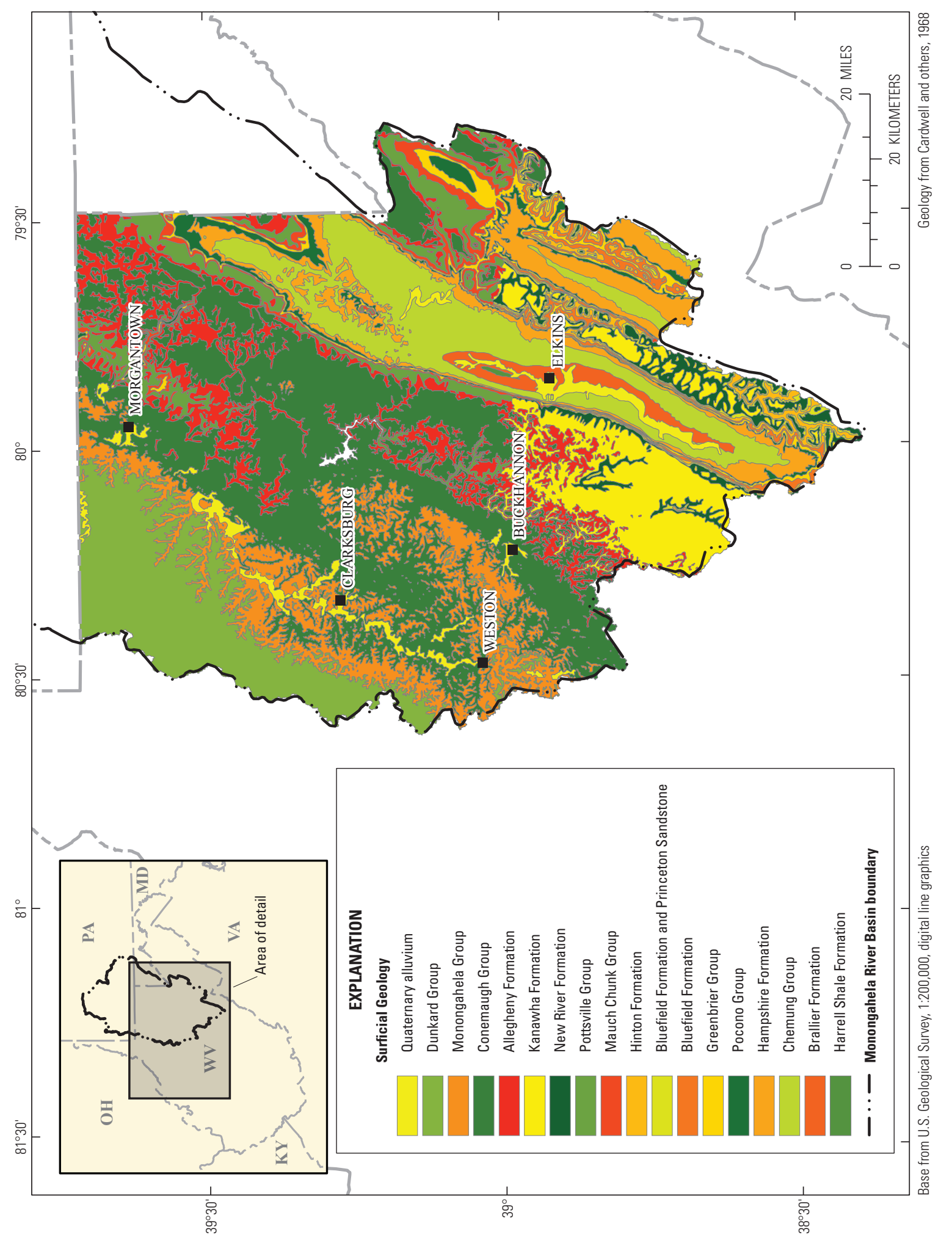

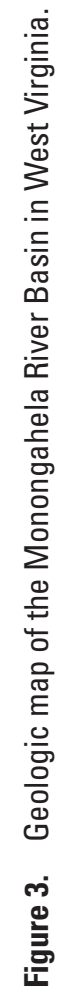




\section{Land Use}

Forest is the most extensive land use in the study area. Agriculture is generally limited and of low intensity (National Agricultural Statistics Service, 2014). The study area includes the cities of Morgantown and Clarksburg, West Virginia, and their suburbs. Morgantown and the surrounding area is among the fastest growing in West Virginia; the population of Morgantown increased 4.5 percent between 2010 and 2012, in contrast to a population growth of 0.2 percent for West Virginia as a whole (U.S. Census Bureau, 2014).

Coal mining was the principal industry in the study area for most of the 20th century. The most important mined coal seams in the study area, underground and surface (fig. 4), are near the western edge, especially within the Dunkard and Monongahela Groups and the Allegheny Formation. The Pittsburgh coal seam is the most historically productive and economically important seam in the study area (Tewalt and others, 2001). The Kittanning, Freeport, Sewickley, Redstone, and Bakerstown coals have also been extensively mined, and at least 15 named coal seams have been mined in the study area. Approximately 16.5 percent of the study area has been mined. Most mines are underground $(15.0 \%$ of the study area), and the remainder are either surface mines ( $2.8 \%$ of the study area) or auger mines ( $0.02 \%$ of the study area), both of which may overlay underground mines. Many areas have been mined multiple times, using multiple methods, or in more than one seam, so that the two-dimensional footprint of mining is an inadequate measure of mining intensity. Most of the coal mined in the study area has high sulfur concentrations ( $>2.5$ percent), and demand for the high-sulfur coal mined here declined following a mandate in the 1991 Clean Air Act amendments to reduce acid precipitation (Milici and Dennen, 2009).

The hydrologic and water-quality effects of both underground and surface mining in the study area are well documented (Anderson and others, 2000; Cravotta, 2008a-b). Acid mine drainage (AMD) from coal mining has had major effects on the quality of water in streams in the region. A variety of acid mine drainage treatment techniques are being used within the study area, and water quality has improved since in the 1970s (Lambert and others, 2004). Continued treatment is necessary to maintain water quality in many places where mining has ended. Typical water-quality effects of coal mining in the study area include increases in concentrations of iron, manganese, aluminum, and sulfate.

Hydrologic effects of coal mining include several important alterations to the movement of water and the magnitude and timing of flow. In underground coal mines, water flows downdip along the mine floor, even in areas where the dip is slight. If the mined seam is above grade, or higher than the valley floor, water is transferred from the updip side of the mountain to the downdip side (Kozar and others, 2013). If the mined seam is below grade, or if it dips from above grade on its uphill side to below grade on the downdip side, water collects in a pool in the void space in a mine (McColloch and others, 2012). Where mining is active, the water is pumped to the surface and discharged. Even after mining ends, water from mine pools may reach land surface through openings if hydraulic head is sufficient.

Recent development of the Marcellus Shale by horizontal drilling and hydraulic fracturing has increased interest in natural gas development, but gas has been produced in the study area for decades. Nearly 6,400 gas wells had been completed in the study area through 2012 (fig. 2; West Virginia Department of Environmental Protection, 2013). The earliest recorded completion date for these wells is during 1895, but completion dates are unknown for most wells drilled before permitting began in 1929. At least 29 named formations have been the targets for gas development in the study area, although the target formation for many older wells is not recorded. Beginning about 2002, the targeting of multiple formations in a single well became common. Through September 2012, 147 wells had been completed in the Marcellus Shale within the study area, 75 of which are horizontal wells.

Both current oil and gas extraction and the legacy effects of improperly abandoned oil and gas wells have affected groundwater and surface-water quality in the region. Natural gas in West Virginia is typically associated with sediments of marine origin, so gas typically is found in association with salty water (Price and others, 1937). Salt and other elements of marine origin are among the common constituents that have become elevated in surface or shallow water as a result of gas development (Bain, 1970). Changes to water quality related to gas development may result from initial surface disturbances, such as site, access road, and pipeline construction; from drilling and fracturing activities; and from maintenance or reclamation activities, such as condensate spills. For conventional wells in West Virginia, activities that may affect water quality include onsite disposal of drilling waste, a practice that was banned for horizontal wells by the West Virginia Natural Gas Horizontal Well Control Act (22-6A-2). Improperly sealed gas wells are known to be a pathway for contaminants to migrate upward from deep rock layers (Bain, 1970), although saline groundwater is naturally as close as 300 feet beneath the surface of some river valleys in the study area (Wilmoth, 1975; Foster, 1980). Of the gas wells in the study area, 215 have a regulatory status of "abandoned," meaning that they are no longer in production but were never sealed and reclaimed.

Underground coal mines and deeper oil and gas reservoirs both produce methane, which has the potential to migrate either by natural processes or potentially as a result of human activities. The isotopic composition, associated ion chemistry, and compositions of associated hydrocarbons can be used to identify the potential source of the gas. Coal-bed methane lacks the associated higher chain hydrocarbons, such as ethane, propane, butane, pentane, and hexane, that may be associated with gases derived from oil and gas reservoirs. Much of 


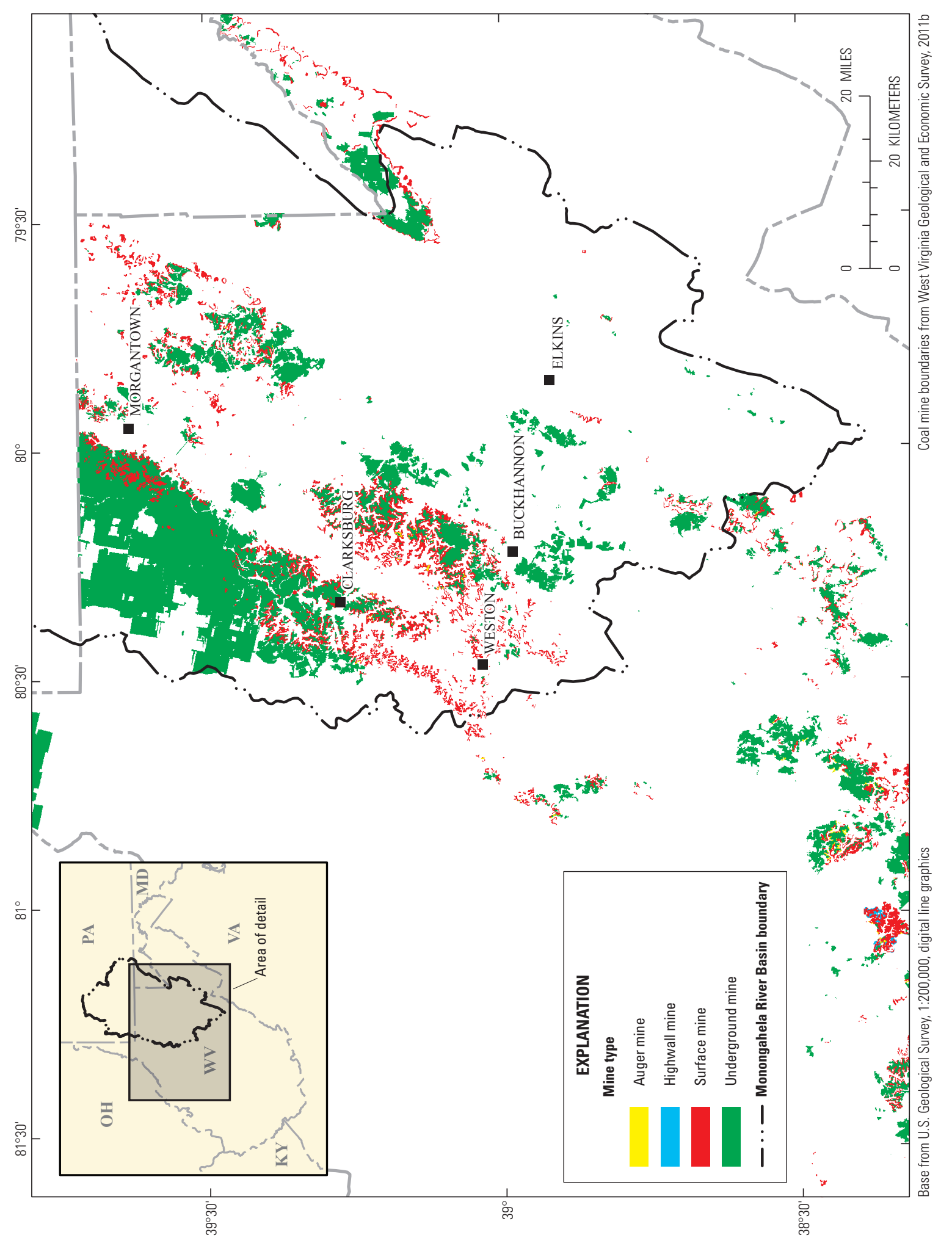

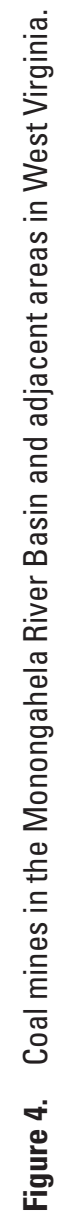


the most active development of the Marcellus Shale targets "wet" gas, or gas rich in ethane and other higher alkanes. The study area also includes natural gas storage fields (U.S. Energy Information Agency, 2014). Although the gas presently stored in these fields is increasingly from the Marcellus Shale, the storage fields hold mixtures of natural gas from a wide variety of sources and locations (U.S. Energy Information Agency, 2004).

\section{Methods of Study}

Baseline water-quality conditions were documented through sampling a combination of wells, springs, and stream sites. Because additives to hydraulic fracturing fluids are variable and decrease in flowback water over a relatively short time, water-quality analyses for this study documented major ions, trace elements, radionuclides, and isotopes (table 1) that can be used to identify the different sources of water - potable water derived from shallow aquifers, water derived from contact with the Marcellus Shale (flowback from hydraulic fracturing or formation water), and water with constituents from other oil and gas fields, sewage effluent, and coal-mine drainage.

\section{Site Selection}

Groundwater and surface-water base-flow quality in the Monongahela River Basin was investigated in 2011 and 2012 to establish baseline water-quality conditions for the study area. Wells were sampled in summer 2011, and surface water was sampled, under base-flow conditions, in summer and fall 2012.

\section{Groundwater}

Groundwater samples were collected from 39 wells and 2 springs in the Monongahela River Basin in West Virginia (fig. 5, table 2). The sites were selected from a group of wells and springs sampled as part of the West Virginia Ambient Groundwater Monitoring network (Chambers and others, 2012), and information was obtained from a database of production wells maintained by the West Virginia Bureau for Public Health. The groundwater survey sites were selected to provide wide areal distribution throughout the study area. However, the distribution of production wells was not sufficient to provide adequate areal coverage. Therefore, samples were also collected from domestic wells, USGS water-level network wells, other types of wells, or springs to provide additional geographic coverage in areas with few production wells.

The criteria for a well to be considered for sampling were as follows: (1) the well had to be less than 25 years old, (2) the well had to have a minimum reported yield of 5 gallons per minute, and (3) the well had to be plumbed or open to allow sampling of raw water prior to any storage tank or treatment. The minimum information required for each well included well depth, location (latitude/longitude), and contributing geologic unit (aquifer). Available well-construction information was recorded (age, depth, and casing length). An on-site inspection was conducted to verify well-casing integrity and adequate well-pad construction to prevent surface contaminants from entering the well bore. Existing submersible pumps were most commonly used for water-sample collection, but for a small number of wells, turbine pumps, jet pumps, or a portable submersible pump were used. Well and site characteristics were obtained during a site visit, from drilling logs, and from well-owner records, where available. If both the minimum criteria and the minimum information requirements were met, the well was selected for sampling. The springs were selected for sampling to supplement geographic coverage in areas with few production wells. The springs selected had been previously sampled and documented (Chambers and others, 2012; Kozar and Brown, 1995).

\section{Surface Water}

Surface-water sites were selected using a stratified design on the basis of availability of historical data, basin size and location, Marcellus Shale thickness (Schwietering and Bocan, 2011; West Virginia Geological and Economic Survey, 2011a), and the presence of gas production from wells tapping the Marcellus Shale (West Virginia Geological and Economic Survey, 2014a) in the hydrologic unit in which the stream is located. To be considered for sampling, a site had to have at least one previous sample collected by the USGS that was analyzed for a full set of major ions and had an associated streamflow measurement. The drainage basins for the sites were limited to a range of 10-40 $\mathrm{mi}^{2}$. Within the study area, 59 surface-water sites met these criteria. Sites were grouped on the basis of gas production at the 12-digit hydrologic unit code (HUC-12) basin level (U.S. Geological Survey, 2005a). Sites were not necessarily at the outlet of the HUC-12. Gas production data, in thousand cubic feet (Mcf), were downloaded from the West Virginia Geological and Economic Survey (WVGES, 2012) Marcellus Shale webpage (http://www.wvgs.wvnet. edu/www/datastat/devshales.htm) on June 4, 2012, and were complete through 2010 at that time. Production data include information on wells targeting multiple formations, only one of which was the Marcellus Shale. "Marcellus wells," as used in this section, includes all of these gas wells.

The surface-water sites were grouped into "bins" that were designated as "High Production," "Low Production," "Near High Production," "Near Low Production," "Underlain by the Marcellus Shale greater than 50 feet thick" (Marcellus $>50 \mathrm{ft}$ thick), and "Underlain by Marcellus Shale less than 50 $\mathrm{ft}$ thick" (Marcellus $<50 \mathrm{ft}$ thick). The break point between high and low production was 1,000 thousand cubic feet per square mile per year (Mcf/mi²/year). The Near High Production bin included sites in a 10-digit hydrologic unit code basin (HUC-10) with gas production exceeding $1,000 \mathrm{Mcf} / \mathrm{mi}^{2} /$ year from Marcellus Shale wells and a site in a HUC-12 with no gas production from Marcellus Shale wells. 


\section{Water quality in the Marcellus Shale Gas Field of the Monongahela River Basin, West Virginia, 2011-12}

Table 1. Water-quality properties, major ions, trace elements, naturally occurring radioactive materials, and dissolved gases analyzed for in groundwater and surface-water samples from the Marcellus Shale baseline survey, Monongahela River Basin, West Virginia, 2011-12.

[NA, not applicable; ${ }^{\circ} \mathrm{C}$, degrees Celsius; $\mu \mathrm{S} / \mathrm{cm}$, microsiemens per centimeter; mg/L, milligrams per liter; FNU, formazin nephelometric units; $\mathrm{CaCO}_{3}$, calcium carbonate; wf, filtered water sample; inflect pt, inflection-point titration; $\mu \mathrm{g} / \mathrm{L}$, micrograms per liter; Cs-137, cesium 137; Th-230, thorium $230 ; \mathrm{pCi} / \mathrm{L}$, picocuries per liter; $\delta$, per mil; ${ }^{13} \mathrm{C}$, carbon- $13,{ }^{18} \mathrm{O}$, oxygen- $18 ;{ }^{2} \mathrm{H}$, deuterium; ${ }^{34} \mathrm{~S}$, sulfur- $34 ; \mathrm{CH} 4$, methane; DIC, dissolved inorganic carbon; $\mathrm{H} 2 \mathrm{O}$, water; $\mathrm{SO} 4$, sulfate; --, none; *, groundwater samples only]

\begin{tabular}{|c|c|c|c|}
\hline Constituent or property & Reporting limit & Constituent or property & Reporting limit \\
\hline Temperature, water, ${ }^{\circ} \mathrm{C}$ & NA & Molybdenum, wf, $\mu \mathrm{g} / \mathrm{L}$ & 0.014 \\
\hline Specific conductance, $\mu \mathrm{S} / \mathrm{cm}$ at $25^{\circ} \mathrm{C}$ & NA & Nickel, wf, $\mu \mathrm{g} / \mathrm{L}$ & 0.09 \\
\hline Dissolved oxygen, $\mathrm{mg} / \mathrm{L}$ & NA & Silver, wf, $\mu \mathrm{g} / \mathrm{L}$ & 0.005 \\
\hline $\mathrm{pH}$, standard units & NA & Strontium, wf, $\mu \mathrm{g} / \mathrm{L}$ & $0.2-0.8$ \\
\hline Redox potential, $\mathrm{mV}^{*}$ & NA & Zinc, wf, $\mu \mathrm{g} / \mathrm{L}$ & 2.0 \\
\hline Turbidity, FNU & NA & Antimony, wf, $\mu \mathrm{g} / \mathrm{L}$ & 0.027 \\
\hline Dissolved solids, dry, at $180^{\circ} \mathrm{C}, \mathrm{mg} / \mathrm{L}$ & 12 & Aluminum, wf, $\mu \mathrm{g} / \mathrm{L}$ & $1.7-2.2$ \\
\hline Alkalinity, wf, inflect, field, $\mathrm{mg} / \mathrm{L} \mathrm{CaCO}_{3}$ & 1 & Selenium, wf, $\mu \mathrm{g} / \mathrm{L}$ & 0.05 \\
\hline Carbonate, wf, inflect pt, field, mg/L & 1 & Gross beta, wf, Cs-137, pCi/L & 4 \\
\hline Bicarbonate, wf, inflect pt, field, mg/L & 1 & Alpha activity, wf, Th-230, pCi/L & 3 \\
\hline Calcium, wf, mg/L & $0.022-0.04$ & Uranium, wf, $\mu \mathrm{g} / \mathrm{L}$ & 0.004 \\
\hline Magnesium, wf, mg/L & 0.08 & Uranium-238, wf, pCi/L & 0.1 \\
\hline Sodium, wf, mg/L & $0.1-0.24$ & Uranium-234, wf, pCi/L & 0.1 \\
\hline Potassium, wf, mg/L & 0.022 & Uranium-235, wf, pCi/L & 0.1 \\
\hline Bromide, wf, mg/L & 0.010 & Radium-224, wf, pCi/L & 1 \\
\hline Chloride, wf, mg/L & $0.02-0.06$ & Radium-226, wf, pCi/L & 1 \\
\hline Sulfate, wf, mg/L & $0.07-0.09$ & Radium-228, wf, pCi/L & 1 \\
\hline Fluoride, wf, mg/L & 0.04 & $\delta^{13} \mathrm{C}_{\mathrm{CH} 4} *$ & -- \\
\hline Silica, wf, mg/L & $0.018-0.029$ & $\delta^{13} \mathrm{C}_{\mathrm{DIC}} *$ & -- \\
\hline Arsenic, wf, $\mu \mathrm{g} / \mathrm{L}$ & $0.02-0.10$ & $\delta^{18} \mathrm{O}_{\mathrm{H} 2 \mathrm{O}} *$ & -- \\
\hline Barium, wf, $\mu \mathrm{g} / \mathrm{L}$ & 0.07 & $\delta^{18} \mathrm{O}_{\mathrm{SO} 4}{ }^{*}$ & -- \\
\hline Beryllium, wf, $\mu \mathrm{g} / \mathrm{L}$ & 0.006 & $\delta^{2} \mathrm{H}_{\mathrm{CH} 4} *$ & -- \\
\hline Boron, wf, $\mu \mathrm{g} / \mathrm{L}$ & 3.0 & $\delta^{2} \mathrm{H}_{\mathrm{H} 2 \mathrm{O}} *$ & -- \\
\hline Cadmium, wf, $\mu \mathrm{g} / \mathrm{L}$ & 0.016 & $\delta^{34} \mathrm{~S}_{\mathrm{SO} 4}{ }^{*}$ & -- \\
\hline Chromium, wf, $\mu \mathrm{g} / \mathrm{L}$ & $0.06-0.07$ & Nitrogen, $\mathrm{N}_{2}$, dissolved, $\mathrm{mg} / \mathrm{L}$ & 0.001 \\
\hline Cobalt, wf, $\mu \mathrm{g} / \mathrm{L}$ & 0.02 & Oxygen, $\mathrm{O}_{2}$, dissolved, $\mathrm{mg} / \mathrm{L}$ & 0.002 \\
\hline Copper, wf, $\mu \mathrm{g} / \mathrm{L}$ & $0.5-0.8$ & Argon, dissolved, mg/L & 0.003 \\
\hline Iron, wf, $\mu \mathrm{g} / \mathrm{L}$ & 3.2 & Carbon dioxide, dissolved, $\mathrm{mg} / \mathrm{L}$ & 0.04 \\
\hline Lead, wf, $\mu \mathrm{g} / \mathrm{L}$ & $0.015-0.025$ & Methane, dissolved, mg/L & 0.001 \\
\hline Manganese, wf, $\mu \mathrm{g} / \mathrm{L}$ & 0.04 & & \\
\hline
\end{tabular}




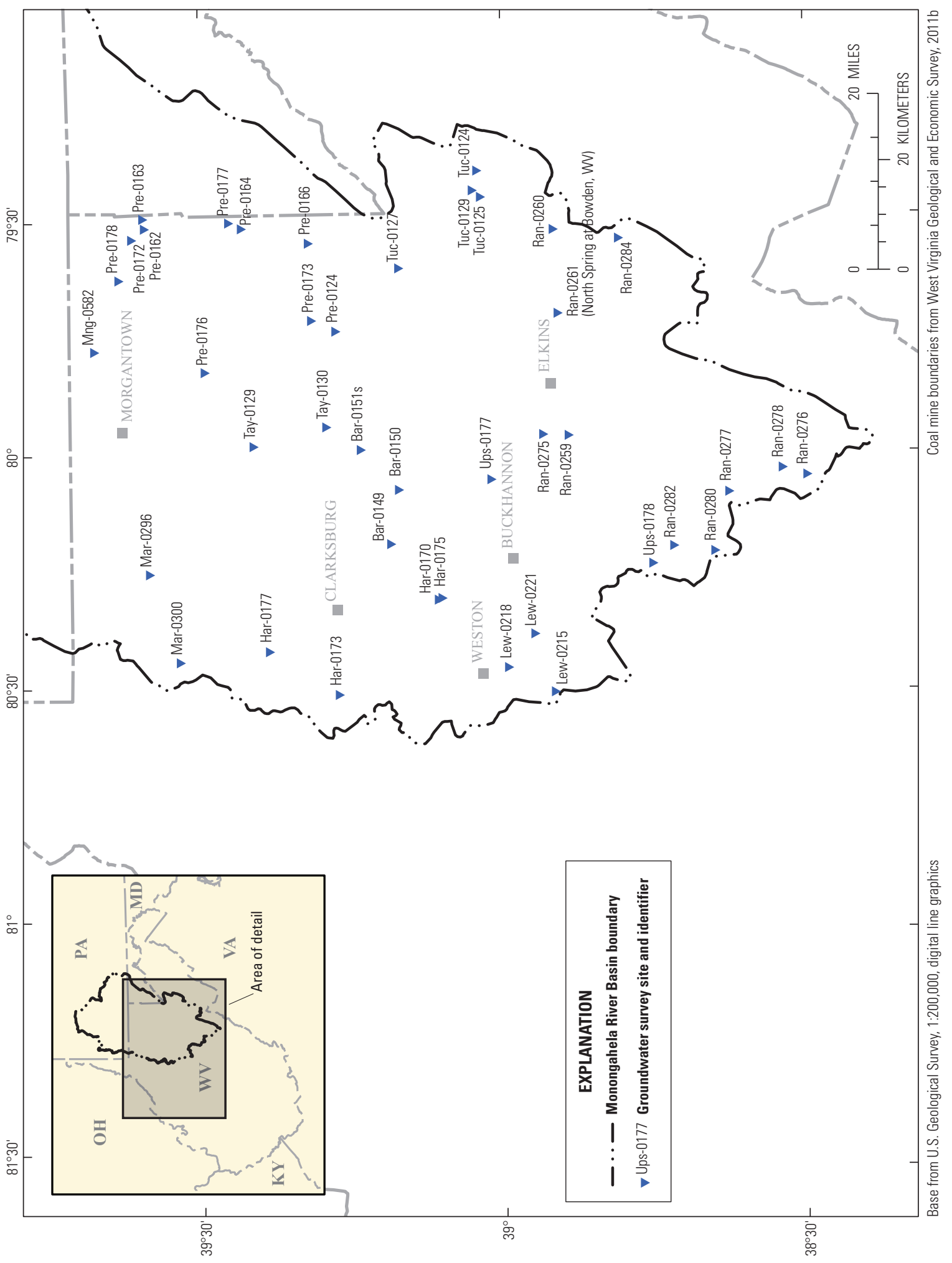

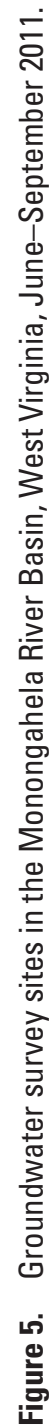


Table 2. Site information for wells and springs sampled for the groundwater survey as part of the Marcellus Shale baseline survey, Monongahela River Basin, West Virginia, June-September 2011.

[WV, West Virginia; Marcellus $<50$, site in basin underlain by a less than 50 -foot Marcellus Shale thickness and neither a gas producing basin nor adjacent to a gas producing basin; NA, not applicable]

\begin{tabular}{|c|c|c|c|c|}
\hline Local well name & Geologic unit name ${ }^{1}$ & Well or spring & Well depth, in feet & Natural gas production bin \\
\hline Mng-0582 & Pottsville Group & Well & 190 & Near production \\
\hline Pre-0163 & Pottsville Group & Well & 179 & Marcellus $<50$ \\
\hline Pre-0162 & Pottsville Group & Well & 145 & Production \\
\hline Pre-0176 & Conemaugh Group & Well & 200 & Near production \\
\hline Ran-0276 & Hampshire Formation & Well & 320 & Not near production \\
\hline Ran-0277 & New River Formation & Well & 220 & Not near production \\
\hline Ran-0280 & Kanawha Formation & Well & 80 & Production \\
\hline Ups-0178 & Kanawha Formation & Well & 158 & Production \\
\hline Ran-0282 & Kanawha Formation & Well & 105 & Production \\
\hline Mar-0296 & Dunkard Group & Well & 107 & Production \\
\hline Mar-0300 & Dunkard Group & Well & 70 & Near production \\
\hline Tay-0129 & Conemaugh Group & Well & 113 & Production \\
\hline Har-0173 & Dunkard Group & Well & 70 & Production \\
\hline Lew-0218 & Monongahela Group & Well & 60 & Near production \\
\hline Har-0170 & Conemaugh Group & Well & 75 & Near production \\
\hline Ran-0259 & Pottsville Group & Well & 155 & Near production \\
\hline Ran-0275 & Kanawha Formation & Well & 500 & Production \\
\hline Ran-0261(North Spring at Bowden, WV) & Greenbrier Group & Spring & NA & Not near production \\
\hline Ups-0177 & Pottsville Group & Well & 120 & Production \\
\hline Tuc-0127 & Chemung Group & Well & 60 & Not near production \\
\hline Tuc-0124 & Greenbrier Group & Well & 100 & Marcellus $<50$ \\
\hline Tuc-0129 & Greenbrier Group & Well & 45 & Marcellus $<50$ \\
\hline Ran-0260 & Price Formation & Well & 222 & Production \\
\hline Tuc-0125 & Greenbrier Group & Well & 250 & Marcellus $<50$ \\
\hline Pre-0124 & Chemung Group & Well & 205 & Not near production \\
\hline Pre-0166 & Price Formation & Well & 100 & Marcellus $<50$ \\
\hline Pre-0173 & Conemaugh Group & Well & 57 & Not near production \\
\hline Ran-0284 & Hampshire Formation & Well & 200 & Marcellus $<50$ \\
\hline Ran-0278 & Chemung Group & Well & 100 & Not near production \\
\hline Lew-0221 & Conemaugh Group & Well & 100 & Production \\
\hline Lew-0215 & Monongahela Group & Well & 100 & Near production \\
\hline Har-0175 & Conemaugh Group & Well & 45 & Near production \\
\hline Bar-0149 & Conemaugh Group & Well & 180 & Production \\
\hline Pre-0177 & Greenbrier Group & Well & 145 & Marcellus $<50$ \\
\hline Pre-0164 & Greenbrier Group & Well & 207 & Marcellus $<50$ \\
\hline Pre-0172 & Allegheny Formation & Well & 65 & Production \\
\hline Pre-0178 & Conemaugh Group & Well & NA & Production \\
\hline Bar-0150 & Conemaugh Group & Well & 52 & Production \\
\hline Har-0177 & Monongahela Group & Well & 150 & Production \\
\hline Тay-0130 & Conemaugh Group & Well & 160 & Not near production \\
\hline Bar-0151s & Conemaugh Group & Spring & NA & Near production \\
\hline
\end{tabular}

${ }^{1}$ Geologic nomenclature used in this report conforms with that used by the West Virginia Geological and Economic Survey, as depicted on the 1968 State geologic map of West Virginia (Cardwell and others, 1968). 
The number of sampling sites in a bin was made proportional to the ratio of the area of the binned HUC-12s within the study area. For instance, High Production HUC-12s made up 17.2 percent of the basin, so 17.2 percent of the sites had to be from that bin. Since 17.2 percent of 50 is 8.6 and sites could only be selected in increments of integers, the number of sites in that bin was rounded to 9 . The category Marcellus $<50 \mathrm{ft}$ thick was eliminated from the study because all available sites were underlain by the Marcellus Shale at less than $2 \mathrm{ft}$ thick and judged to be unlikely candidates for future development. The Marcellus $<50 \mathrm{ft}$ thick bin made up 10 percent of the overall study area, and the five sites that would have represented this bin were allocated to the Near High Production bin.

After setting up the bins, sites were prioritized by assigning at least one site from each HUC-10 that was represented, then at least one site in each HUC-12 until the bins filled up (fig. 6). If the only available sites for a bin were within the same HUC-12, then multiple sites from that HUC-12 were used. This was done by assigning random numbers to sites within HUC-10s, and then within HUC-12s, and ranking them by the random numbers. Sites were then sorted by (1) bin, (2) HUC-10 rank, (3) HUC-12 rank, and (4) random number, and ordered within bins. Sites with within-bin rank less than or equal to the number of sites per bin were included in the study, and the next site in rank was assigned as the alternate. Using this procedure, two sites were selected in close proximity on the same stream; one site with three samples collected during 1979-80, and the other with an active streamgage, 64 years of flow data, and numerous water-quality measurements (fig. 7). Both sites drain between $10 \mathrm{mi}^{2}$ and $20 \mathrm{mi}^{2}$. Although this procedure ranked the ungaged site higher, the streamgage site was selected for sampling. Finally, during sampling, field crews visited one of the selected sites shortly after limestone sand had been applied to treat acid mine drainage. That site was dropped from the study and replaced by a site in the same bin but with a drainage area of $40.7 \mathrm{mi}^{2}$, which was slightly greater than the original size criterion (table 3 , at end of report).

\section{Sampling Methods}

Both groundwater and base-flow samples were collected and processed according to standard USGS operating procedures and protocols. All samples were analyzed for field properties, alkalinity, major ions, trace elements, and uranium (table 1). Field measurements of water temperature, specific conductance, dissolved oxygen concentration, $\mathrm{pH}$, alkalinity, and, for groundwater sites, redox potential were made on site according to standard protocols (U.S. Geological Survey, 2006). Samples were processed according to standard USGS protocol (Wilde and others, 2004). Water samples for cation analysis were filtered through a 0.45 -micron $(\mu \mathrm{m})$ filter, collected in an acid-rinsed 250-milliliter (mL) polyethylene bottle, and acidified with $2 \mathrm{~mL}$ of nitric acid. Water samples for anion analysis were collected in a $250-\mathrm{mL}$ polyethylene bottle. Water samples for uranium and radium isotope analysis were collected in a 1-liter (L) polyethylene bottle. If uranium was detected in a sample, that sample was further analyzed for uranium and radium isotopes.

Analyses for major ions, trace elements, and naturally occurring radioactive materials (NORM) were conducted at the USGS National Water Quality Laboratory (NWQL) in Denver, Colorado. Stable isotope analyses were performed at the West Virginia University Stable Isotope Laboratory in Morgantown, West Virginia, and Isotech Laboratories in Champaign, Illinois. Dissolved gas samples were analyzed at the USGS Dissolved Gas Laboratory in Reston, Virginia.

\section{Groundwater Sampling}

Groundwater samples were collected between June 28 and September 21, 2011. Prior to sampling, wells were purged to remove standing water from the well and ensure that representative water samples were collected. A minimum of one well volume was purged from most wells; high-use production wells that did not require purging or low-yielding wells that would not recover from purging were pumped until field properties stabilized. Field measurements of dissolved oxygen, $\mathrm{pH}$, specific conductance, water temperature, and turbidity were monitored during purging by using a multi-parameter water-quality meter, which was calibrated daily. Water level was also monitored where possible. Sample tubing typically was connected to a $3 / 4-i n$. hose bib as close to the wellhead as possible, and pumps were kept on to prevent sample contamination from the plumbing or from backflow from holding tanks. Existing plumbing and well-casing materials included, but were not limited to, steel, galvanized steel, copper, polyvinyl chloride (PVC), and other plastics. The purging procedure prescribed was assumed to have prevented contamination from plumbing materials. Samples were collected after field properties stabilized, according to standard USGS protocols for the collection of water-quality data (U.S. Geological Survey, 2006). Each of the sampled springs discharges into a collection basin, and samples from springs were collected using a peristaltic pump to draw water from the collection basin. Subsurface-dip samples were collected from the spring's collection basin for dissolved gas analyses. Field properties were measured in the collection basin before and during sample collection to monitor the stability of the spring's discharge. To prevent environmental contamination, samples typically were collected and processed inside a mobile field laboratory or a portable chamber assembled near the well or the spring.

\section{Base-Flow Sampling}

Base-flow samples were collected from 50 sites in the Monongahela River Basin during seasonal base-flow conditions between July 31 and October 26, 2012. Samples were collected using methods described in the USGS National Field Manual for the collection of Water-Quality Data (U.S. Geological Survey, 2006). Where possible, depth- and 


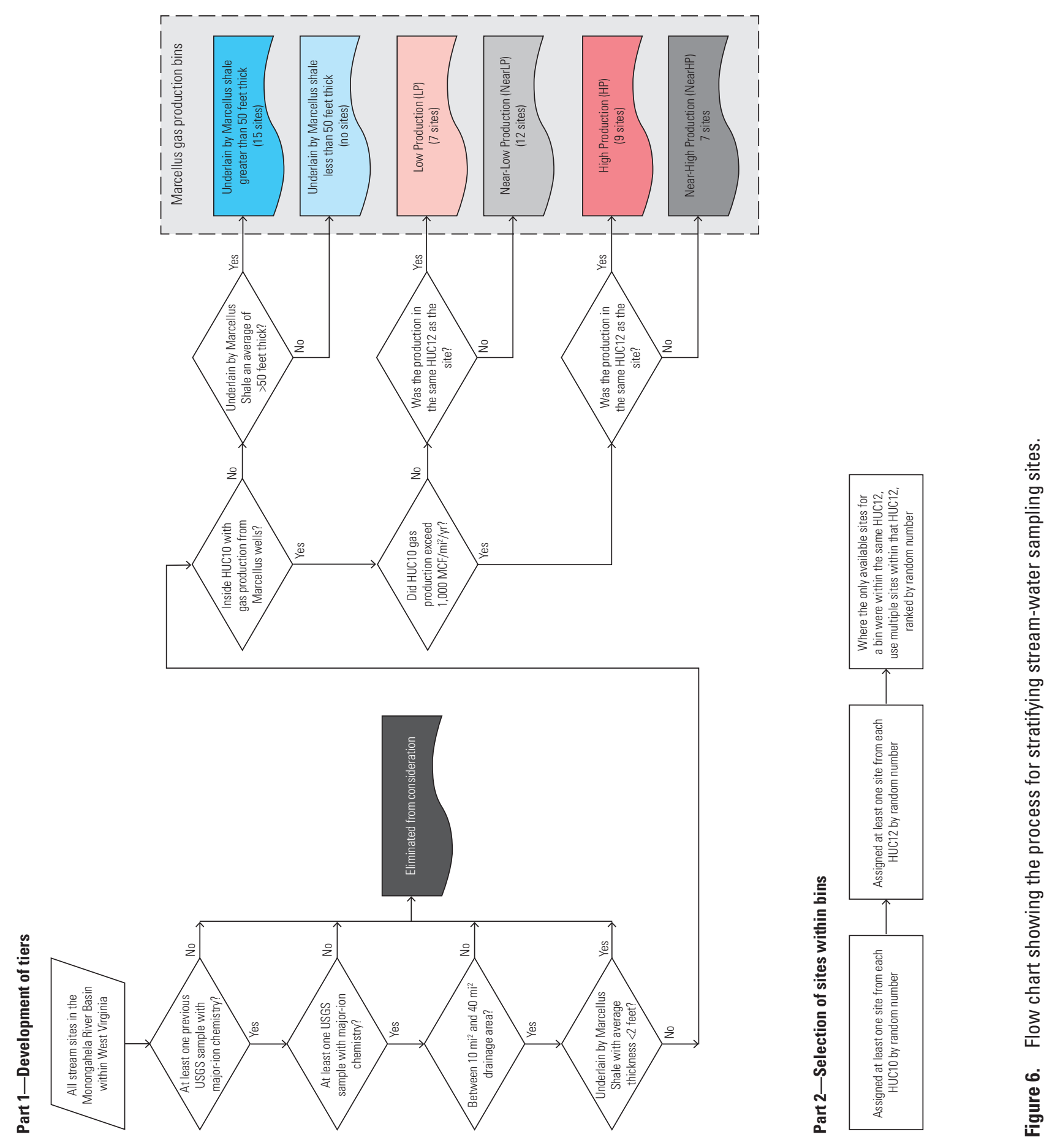




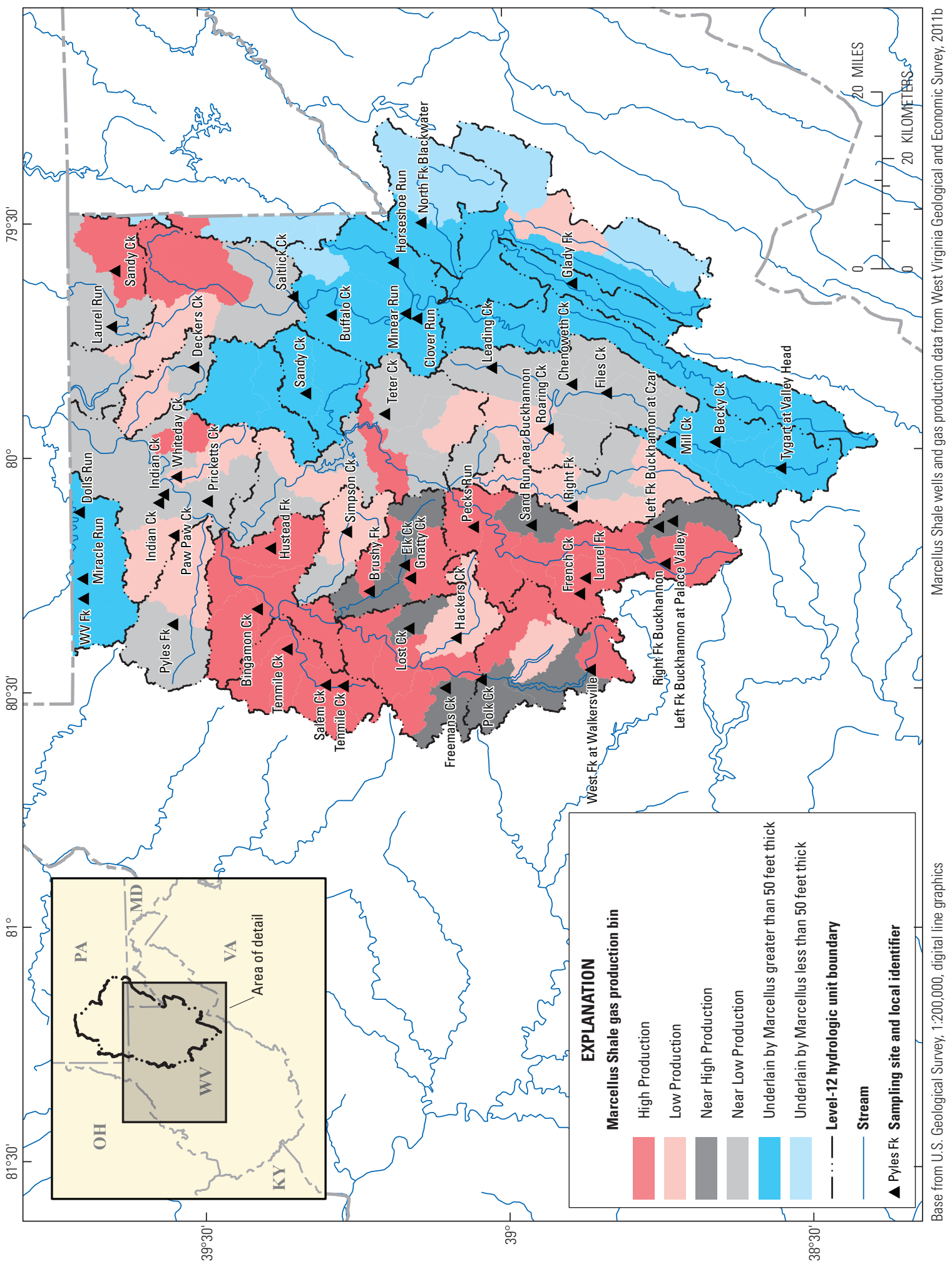

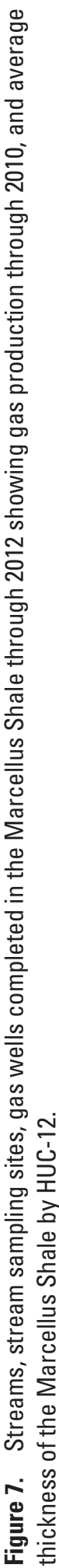


width-integrated samples were collected using a DH-81 isokinetic sampler. Where site conditions did not support the use of a DH-81, such as insufficient stream depth or velocity, samples were collected at multiple points using an openmouthed bottle. Sample aliquots were composited in a churn splitter and processed according to standard USGS protocols (U.S. Geological Survey, 2006). Field properties of water temperature, specific conductance, dissolved oxygen concentration, $\mathrm{pH}$, alkalinity, and stream discharge were measured at the time of sample collection.

\section{Methods of Analysis}

The results of the groundwater survey and base-flow survey were examined for geospatial and statistical relations. The geospatial and statistical analyses of the waterchemistry results were conducted to discern patterns in these data. Details of these analyses are described in the following two sections.

\section{Geospatial Analyses}

The wells and springs sampled and the associated waterchemistry data were assessed for spatial trends by loading the data into ArcMap, a geographic information system (GIS) tool for analysis of geospatial data. Additional geospatial data were used to assess potential factors that could affect groundwater quality in the region. The geospatial data included (1) location of current and legacy coal mines obtained from the WVGES (West Virginia Geological and Economic Survey, 2011b), (2) location of current active or recently completed Marcellus Shale gas wells (from WVGES, West Virginia Geological and Economic Survey, 2014a), (3) geologic maps of the study area with significant surficial and deeper structural features such as faults and folds (from WVGES), (4) location of current and historical oil and gas wells (from WVGES), (5) elevation data from the USGS National Elevation Dataset, (6) stream coverages from the USGS National Hydrography Dataset (NHD), and (7) basin characteristics derived from the USGS NHD database.

\section{Statistical Analyses}

Descriptive and summary statistics were calculated using Spotfire S-PLUS 8.1 statistical and graphing software (TIBCO Software, Inc., 2008). Descriptive and summary statistics for censored data sets, those with values less than the reporting level, were calculated using the Regression on Order Statistics (ROS) and adjusted maximum likelihood estimation (AMLE) techniques (TIBCO Software Inc., 2008). Statistics were not calculated for sample sets of less than 10 data points. Kruskal-Wallis rank test was used for comparison of medians among groups. A Tukey's Honest-Significant-Difference post hoc test was used for multiple comparisons. Relations among several variables were analyzed through Principal Components Analysis (PCA). Analysis of groundwater-quality data for geochemical processes was performed using the PCA in Spotfire S-PLUS 8.1 statistical and graphing software.

\section{Quality Assurance}

Quality-assurance samples, blanks, and replicates were collected during both the groundwater sampling and the surface-water base-flow sampling. Blank samples are used to determine the extent to which sampling procedures may contaminate samples, thereby biasing analytical results. Replicate samples are used to determine the variability inherent in the collection and analysis of environmental samples. Together, blank and replicate samples can be used to characterize the accuracy and precision of water-quality data. All qualityassurance samples were collected and processed according to protocols described in the USGS National Field Manual for the Collection of Water-Quality Data (U.S. Geological Survey, 2006).

\section{Blank Samples}

A combination of equipment blanks and field blanks was used to identify and quantify potential sources of contamination. An equipment blank consists of a volume of water of known quality that is processed through the sampling equipment in a laboratory environment. A field blank consists of a volume of water processed through the sampling equipment under the same field conditions in which the samples were processed, typically a mobile field laboratory.

\section{Replicate Samples}

Comparison of results among replicate samples can provide insight into the sources of variability that are inherent in sample collection, processing, and analysis. Sample-collection protocols (U.S. Geological Survey, 2006) for groundwater and base-flow samples have been developed to produce a sample that is representative of the sampled well, spring, or stream. If the appropriate sampling procedures have been used, it is assumed that the water being collected is representative of the sampled environment and that any variability among the main and replicate sample is primarily attributable to sample processing and analysis (Koterba and others, 1995).

Variability for a replicate sample pair was quantified by calculating the relative percent difference (RPD) of the samples. The RPD was calculated using the following formula:

$$
\left(\frac{\left|R_{1}-R_{2}\right|}{\left(\frac{R_{1}+R_{2}}{2}\right)}\right) \times 100,
$$

where $R_{1}$ is the concentration of the analyte in the first replicate sample and $R_{2}$ is the concentration of the analyte in the second replicate sample. Generally, concentrations in replicate sample pairs differed by small amounts, typically less than 15 percent RPD. 


\section{Quality-Assurance Results}

\section{Groundwater Samples}

An equipment blank was collected prior to collection of groundwater samples in 2011. The blank sample was analyzed using the same analytical suite as the environmental samples. The only analyte present in this blank at a detectable concentration was cobalt, at 0.052 micrograms per liter $(\mu \mathrm{g} / \mathrm{L})$; the detection was confirmed through a re-analysis of the sample. The detection appears anomalous because cobalt concentrations in 15 of the 41 environmental samples processed using this equipment were lower than the concentrations detected in the blank sample.

Replicate samples were collected at two sites, Har-0177 and Ran-0259 (table 2), during the groundwater survey. In general, the replicate samples were in good agreement, with most analyses within 5 percent RPD. All values for the Har-0177 sample pair were within 15 percent RPD. However, the replicate samples from Ran-0259 differed by more than 15 percent RPD for aluminum and arsenic. The aluminum results for the Ran- 0259 sample pair were $3.4 \mu \mathrm{g} / \mathrm{L}$ and $2.1 \mu \mathrm{g} / \mathrm{L}$, a difference of 47 percent RPD. The reporting level for aluminum analysis using this method was $1.7 \mu \mathrm{g} / \mathrm{L}$. However, the long-term minimum detection level (LTMDL) for this method is $2.2 \mu \mathrm{g} / \mathrm{L}$, a value calculated using data from the period this sample pair was analyzed. The sample pair results for arsenic were $0.1 \mu \mathrm{g} / \mathrm{L}$ and $0.08 \mu \mathrm{g} / \mathrm{L}$, a difference of 22 percent RPD with a reporting level of $0.04 \mu \mathrm{g} / \mathrm{L}$.

\section{Base-Flow Samples}

Field blank samples were collected at the Tygart Valley River at Valley Head and the Elk Creek at Romines Mills sites. Lead was the only analyte detected in the Tygart Valley River blank with a concentration of $0.027 \mu \mathrm{g} / \mathrm{L}, 0.002 \mu \mathrm{g} / \mathrm{L}$ greater than the method reporting level of $0.025 \mathrm{mg} / \mathrm{L}$. Lead was not detected in the environmental sample collected from the Tygart Valley River. Both silica and cobalt were detected in the Elk Creek blank, silica at 0.043 milligrams per liter $(\mathrm{mg} / \mathrm{L})$ and cobalt $0.038 \mu \mathrm{g} / \mathrm{L}$, analytes with laboratory reporting limits of $0.018 \mathrm{mg} / \mathrm{L}$ and $0.021 \mu \mathrm{g} / \mathrm{L}$, respectively. The silica concentration in the blank is much lower than the minimum environmental concentration of $1.68 \mathrm{mg} / \mathrm{L}$ measured and two orders of magnitude less than the median environmental concentration. It is unlikely silica contamination significantly affected the analysis of any environmental sample or the interpretation of the data. Cobalt concentrations in environmental samples ranged from 0.043 to $20.6 \mu \mathrm{g} / \mathrm{L}$. The cobalt concentrations in samples collected in the weeks immediately prior to collection of the blank sample were an order of magnitude greater than concentrations for the blank. The Tygart Valley River blank, which had no detectable cobalt, was processed the week following the Elk Creek blank. The presence of cobalt at a detectable concentration in the Elk Creek blank is unlikely to affect the interpretation of cobalt data.

A replicate sample was collected at Little Sandy Creek at Evansville, W.Va. A replicate sample consists of two samples collected from the same sampling location at the same time. Replicate samples chiefly provide data on variability associated with sampling and analytical methods. The replicate sample pair agreed well; concentrations for 32 of 37 analytes in both samples differed by less than 5 percent RPD. Only one analyte in this sample pair, molybdenum, differed by greater than 15 percent RPD, at 17 percent RPD. The concentrations of molybdenum for the sample pair were $0.019 \mu \mathrm{g} / \mathrm{L}$ and $0.016 \mu \mathrm{g} / \mathrm{L}$, and the reporting level was $0.014 \mu \mathrm{g} / \mathrm{L}$.

\section{Water Quality in the Monongahela River Basin}

The baseline water-quality assessment of that part of the Monongahela River Basin underlain by the Marcellus Shale consisted of a groundwater survey and a base-flow survey. The results of both surveys were compared to historical waterquality data for the study area stored in NWIS databases. Historical data used for comparison to the base-flow survey data were restricted to samples collected during the same season, July through October. For the base-flow survey results, further comparisons were made among gas-production bins described in the section "Surface Water" under "Site Selection." Owing to the small number of sites in some of the bins, a simplified classification structure was used consisting of only three bins - Production, basins with high or low gas production; Near Production, basins without gas production but adjacent to production basins; and Not Near Production, basins underlain by greater than a $50-\mathrm{ft}$ thickness of the Marcellus Shale but neither producing gas nor adjacent to a Marcellus Shale gas-producing basin. Groundwater-survey sites were binned using the same basin designation as that used for the base-flow survey with the addition of a fourth group "Marcellus $<50$ " for groundwater sites not in basins underlain by at least a $50-\mathrm{ft}$ thickness of the Marcellus shale. These comparisons reflect both temporal and current land-use patterns. The results of this study can be found in data tables included in the appendixes for this report; groundwater survey results are in Appendix 1, and the base-flow survey results are in Appendix 2.

\section{Specific Conductance, Total Dissolved Solids, and $\mathrm{pH}$}

Specific conductance and $\mathrm{pH}$ of groundwater and surface water provide a general indication of water quality and can affect other chemical constituents present by affecting solubility, partitioning, and valence states. Although much of the variability of specific conductance and $\mathrm{pH}$ in groundwater is due to natural factors, human activities, such 
as coal mining, also contribute to this variability (McAuley and Kozar, 2006). Total dissolved solids, the concentration of dissolved substances in water, is often highly correlated with specific conductance.

\section{Specific Conductance}

Specific conductance, the ability of water to conduct an electrical current, is dependent upon the amount of dissolved ions present in the water. Specific conductance in groundwater samples ranged from 44 microsiemens per centimeter at 25 degrees Celsius $(\mu \mathrm{S} / \mathrm{cm})$ to $794 \mu \mathrm{S} / \mathrm{cm}$, with a median value of $295 \mu \mathrm{S} / \mathrm{cm}$. In the base-flow survey samples, specific conductance ranged from $56 \mu \mathrm{S} / \mathrm{cm}$ to $5,380 \mu \mathrm{S} / \mathrm{cm}$ with a median value of $280 \mu \mathrm{S} / \mathrm{cm}$ (table 4$)$. It is worth noting that although the minimum and median specific conductance values for the groundwater and base-flow surveys are similar, the maximum value for the groundwater survey is an order of magnitude lower than the median value for the base-flow survey. Specific conductance did not differ significantly from historical values in either the groundwater survey or the baseflow survey (fig. 8). Specific conductance varied significantly among the base-flow survey gas-production bins (KruskalWallis test, $p=0.011$ ) with the highest values in the Production bin (fig. 9). The groundwater production bins did not differ in regard to specific conductance $(p=0.435)$.

Table 4. Statistical summary of water-quality field measurements and major ions in samples collected for the groundwater survey and base-flow survey as part of the Marcellus Shale baseline survey, Monongahela River Basin, West Virginia, $2011-12$.

$[\mu \mathrm{S} / \mathrm{cm}$, microsiemens per centimeter at 25 degrees Celsius; $\mathrm{mg} / \mathrm{L}$, milligrams per liter; wf, filtered sample; SMCL, secondary maximum contaminant level (U.S. Environmental Protection Agency, 2009); <, less than; NA, not applicable]

\begin{tabular}{|c|c|c|c|c|c|c|c|}
\hline Constituent & $\begin{array}{l}\text { Reporting } \\
\text { unit }\end{array}$ & $\begin{array}{c}\text { Method } \\
\text { reporting level }\end{array}$ & Survey & $\begin{array}{c}\text { Minimum } \\
\text { value }\end{array}$ & $\begin{array}{c}\text { Maximum } \\
\text { value }\end{array}$ & $\begin{array}{c}\text { Median } \\
\text { value }\end{array}$ & SMCL \\
\hline \multirow{2}{*}{$\mathrm{pH}$} & \multirow{2}{*}{ Standard unit } & \multirow{2}{*}{ NA } & Groundwater & 4.5 & 9.4 & 7 & \multirow{2}{*}{$6.5-8.5$} \\
\hline & & & Base flow & 4.8 & 8.7 & 7.7 & \\
\hline \multirow{2}{*}{ Specific conductance } & \multirow{2}{*}{$\mu \mathrm{S} / \mathrm{cm}$} & \multirow{2}{*}{ NA } & Groundwater & 44 & 794 & 295 & \multirow{2}{*}{ NA } \\
\hline & & & Base flow & 56 & 5,380 & 280 & \\
\hline \multirow{2}{*}{ Total dissolved solids } & \multirow{2}{*}{$\mathrm{mg} / \mathrm{L}$} & \multirow{2}{*}{12} & Groundwater & $<12$ & 522 & 168 & \multirow{2}{*}{ NA } \\
\hline & & & Base flow & 37 & 4,380 & 171 & \\
\hline \multirow{2}{*}{ Calcium, wf } & \multirow{2}{*}{$\mathrm{mg} / \mathrm{L}$} & \multirow{2}{*}{$0.022-0.04$} & Groundwater & 0.672 & 91 & 16.9 & \multirow{2}{*}{ NA } \\
\hline & & & Base flow & 5.51 & 291 & 28.3 & \\
\hline \multirow{2}{*}{ Magnesium, wf } & \multirow{2}{*}{$\mathrm{mg} / \mathrm{L}$} & \multirow{2}{*}{0.08} & Groundwater & 0.105 & 19.1 & 4.07 & \multirow{2}{*}{ NA } \\
\hline & & & Base flow & 1.26 & 86.3 & 28.3 & \\
\hline \multirow{2}{*}{ Potassium, wf } & \multirow{2}{*}{$\mathrm{mg} / \mathrm{L}$} & \multirow{2}{*}{0.022} & Groundwater & 0.43 & 2.9 & 1.17 & \multirow{2}{*}{ NA } \\
\hline & & & Base flow & 0.66 & 8.85 & 1.98 & \\
\hline \multirow{2}{*}{ Sodium, wf } & \multirow{2}{*}{$\mathrm{mg} / \mathrm{L}$} & \multirow{2}{*}{$0.1-0.24$} & Groundwater & 0.46 & 186 & 17.2 & \multirow{2}{*}{ NA } \\
\hline & & & Base flow & 0.89 & 949 & 8.31 & \\
\hline \multirow{2}{*}{ Bicarbonate, wf } & \multirow{2}{*}{$\mathrm{mg} / \mathrm{L}$} & \multirow{2}{*}{1.} & Groundwater & 2.3 & 382 & 99.8 & \multirow{2}{*}{ NA } \\
\hline & & & Base flow & $<1$ & 401 & 65 & \\
\hline \multirow{2}{*}{ Chloride, wf } & & & Groundwater & 0.57 & 67.6 & 9.42 & \\
\hline & $\mathrm{mg} / \mathrm{L}$ & $0.02-0.06$ & Base flow & 0.87 & 100 & 6.94 & 250 \\
\hline & & & Groundwater & $<0.01$ & 0.598 & 0.027 & \\
\hline Bromide, wf & $\mathrm{mg} / \mathrm{L}$ & 0.010 & Base flow & 0.014 & 0.692 & 0.031 & NA \\
\hline Fluride uff & $\mathrm{mo/I}$ & 004 & Groundwater & $<0.04$ & 1.85 & 0.1 & 1 \\
\hline Fluoride, WI & $\mathrm{mg} / \mathrm{L}$ & 0.04 & Base flow & $<0.04$ & 0.27 & .06 & 4 \\
\hline Sulfate wf & $\mathrm{mo} / \mathrm{I}$ & 00700 & Groundwater & $<0.09$ & 231 & 10.18 & 250 \\
\hline Sulfate, wt & $\mathrm{mg} / \mathrm{L}$ & $0.01-0.9$ & Base flow & 3.42 & 2,640 & 9.1 & 250 \\
\hline
\end{tabular}


$\boldsymbol{A}$

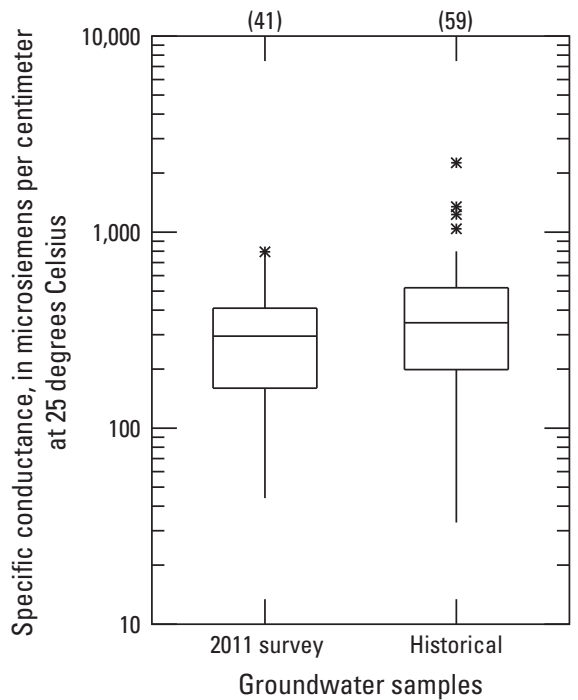

$\boldsymbol{B}$

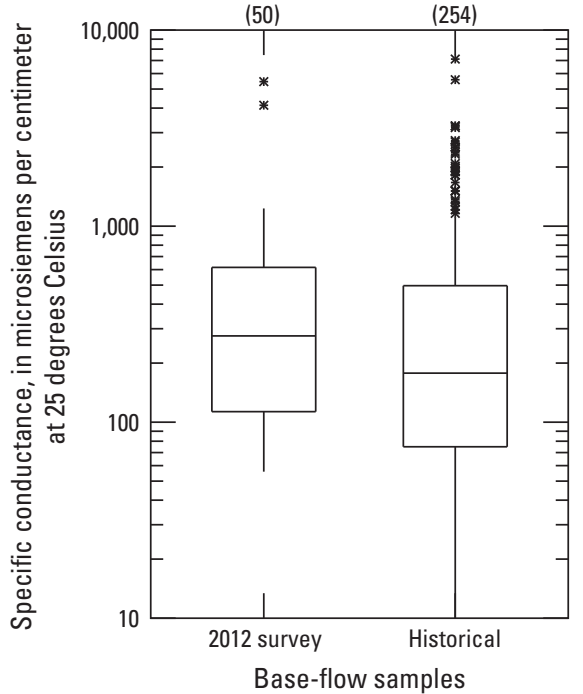

EXPLANATION

Number of samples

* Outlier

1.5 times interquartile range

75th percentile

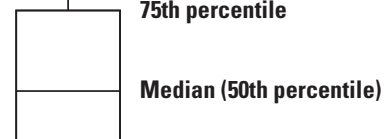

25th percentile

-1.5 times interquartile range

Figure 8. Distribution of specific conductance for samples collected as part of the Marcellus Shale baseline study, 2011-12, and historical specific conductance for samples collected in the Monongahela River Basin, West Virginia: $A$, groundwater samples and $B$, base-flow samples.
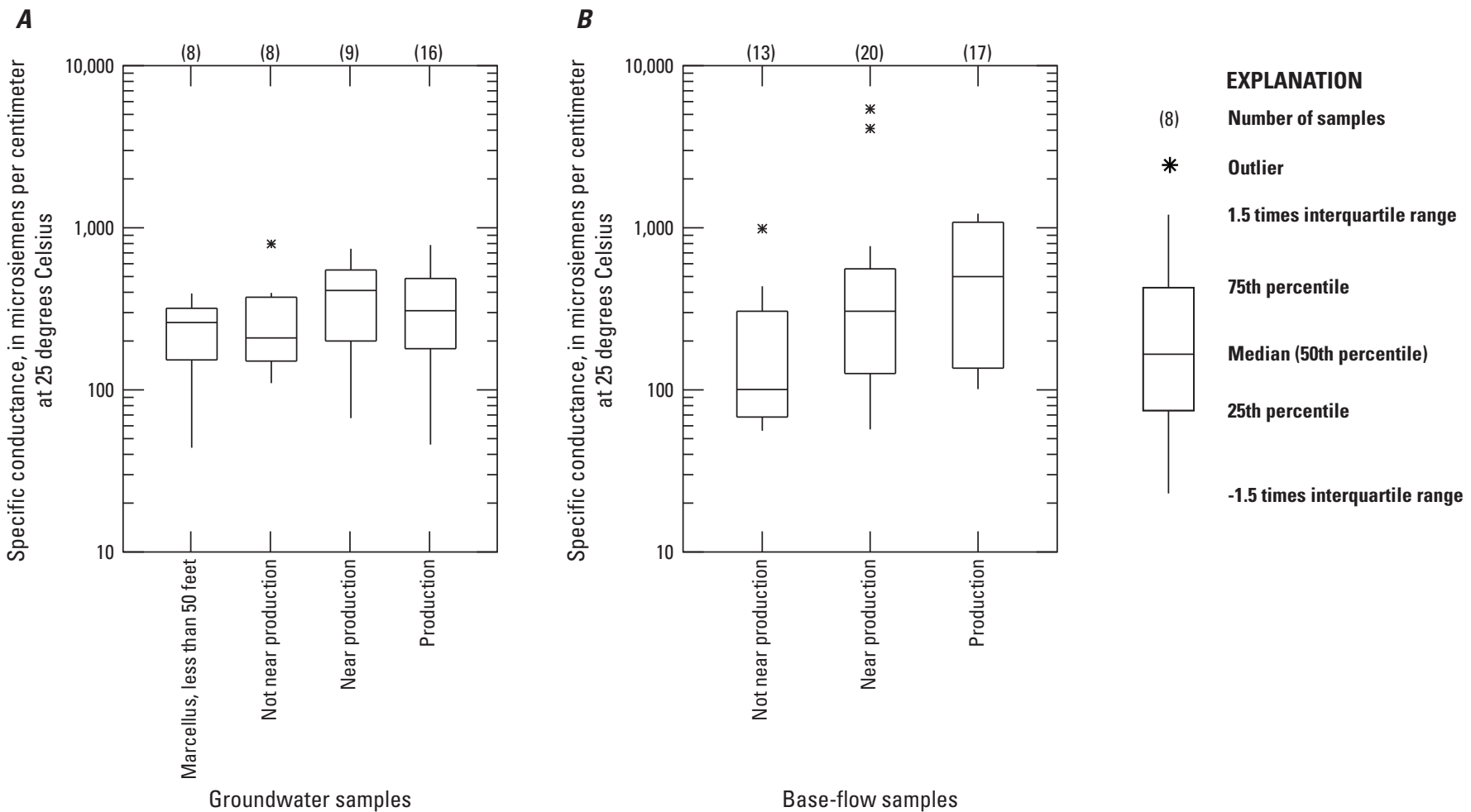

Figure 9. Distribution of specific conductance for samples collected as part of the Marcellus Shale baseline study, Monongahela River Basin, West Virginia, 2011-12, grouped by gas production type: $A$, groundwater samples and $B$, base-flow samples. 


\section{Total Dissolved Solids}

Concentrations of total dissolved solids in groundwater survey samples ranged from less than the reporting level of $12 \mathrm{mg} / \mathrm{L}$ to $522 \mathrm{mg} / \mathrm{L}$ with a median value of $168 \mathrm{mg} / \mathrm{L}$. Concentrations of total dissolved solids in base-flow survey samples ranged from $37 \mathrm{mg} / \mathrm{L}$ to $4,380 \mathrm{mg} / \mathrm{L}$ with a median of $171 \mathrm{mg} / \mathrm{L}$ (table 4 ), the same as the median groundwater concentration. As with specific conductance, there are no significant differences between historical data and either groundwater survey or base-flow survey data. Also, as was the case for specific conductance, total dissolved solids concentrations in base-flow survey samples varied significantly by gasproduction bin (Kruskal-Wallis test, $\mathrm{p}=0.019$ ). The highest concentrations were in the Production bin, and there were no significant differences among the groundwater survey gasproduction bins.

$\mathrm{pH}$

The $\mathrm{pH}$ of a solution plays an important role in the solubility of metals. The $\mathrm{pH}$ of the groundwater survey samples ranged from 4.5 to 9.4 with a median of 7.0. The $\mathrm{pH}$ of baseflow survey samples ranged from 4.8 to 8.7 with a median of 7.7 (table 4). The U.S. Environmental Protection Agency (EPA) has established a secondary maximum contaminant level (SMCL) for $\mathrm{pH}$. The SMCL is a recommendation based on aesthetic effects, primarily taste, that ideally $\mathrm{pH}$ would fall within the range of 6.5 to 8.5 (U.S. Environmental Protection Agency, 2009). A total of 14 samples fell outside the SMCL range - 9 groundwater samples, (6 samples were less than 6.5 and 3 samples exceeded 8.5) and 5 base-flow samples ( 2 samples were less than 6.5 and 3 samples exceeded 8.5).

Values of $\mathrm{pH}$ in samples collected for the 2011groundwater survey did not differ significantly from values of the historical data (fig. 10). However, $\mathrm{pH}$ measured during the 2012 base-flow survey was significantly higher than historical values (Kruskal-Wallis test, $\mathrm{p}<0.001$ ). The difference between base-flow survey $\mathrm{pH}$ values and historical $\mathrm{pH}$ values is most likely attributable to changes in coal-mining practices and acid-mine-drainage treatment that have occurred between the 2012 and historical surveys. Among base-flow survey samples, $\mathrm{pH}$ values in the Production bin were higher than those in the Not Near Production bin (Kruskal-Wallis test, $\mathrm{p}=0.097$ ) (fig. 11A). There was no difference among groundwater survey bins (Kruskal-Wallis test, $\mathrm{p}=0.252$ ) (fig. 11B).

\section{Major lons}

The major ions calcium, magnesium, potassium, sodium, bicarbonate from field alkalinity, chloride, and sulfate exert a strong influence on, and are strongly influenced by, geochemical and anthropogenic processes. Patterns in major ion composition were examined by determination of water type, as well as comparison of historical and 2011-12 survey data. For the base-flow survey samples, further comparisons were made among the gas-production bins.

The relative proportion of major ions in natural waters is the basis for classifying samples by water type. Water
$\boldsymbol{A}$

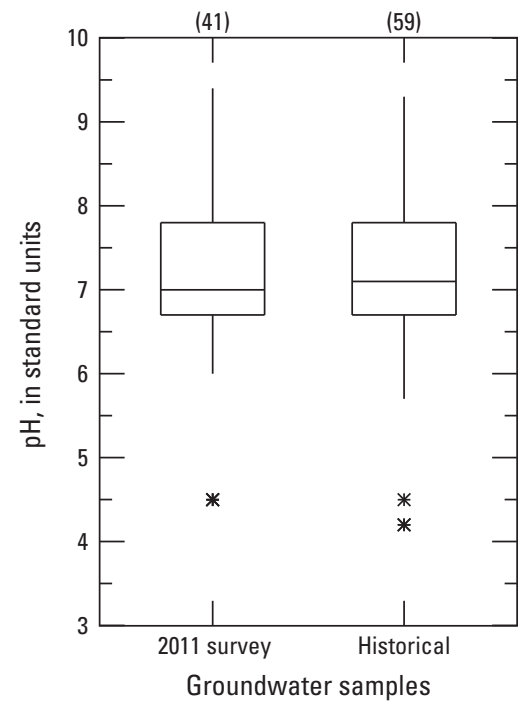

B

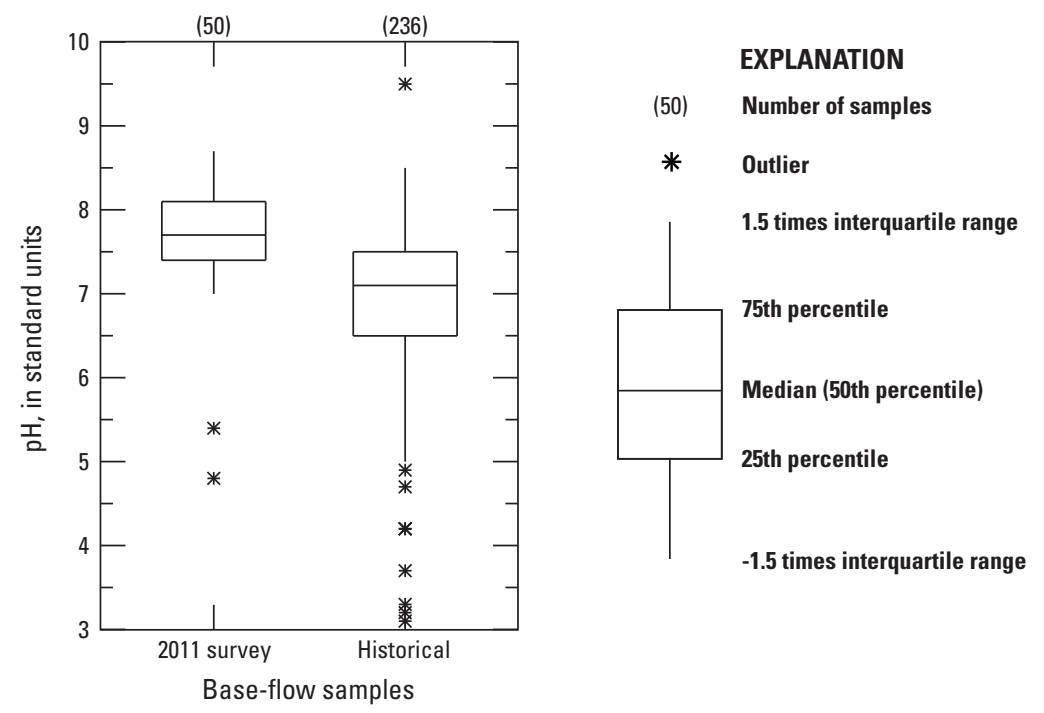

Figure 10. Distribution of $\mathrm{pH}$ in samples collected as part of the Marcellus Shale baseline study, 2011-12, and historical pH in samples from the Monongahela River Basin, West Virginia: $A$, groundwater samples and $B$, base-flow samples. 
A

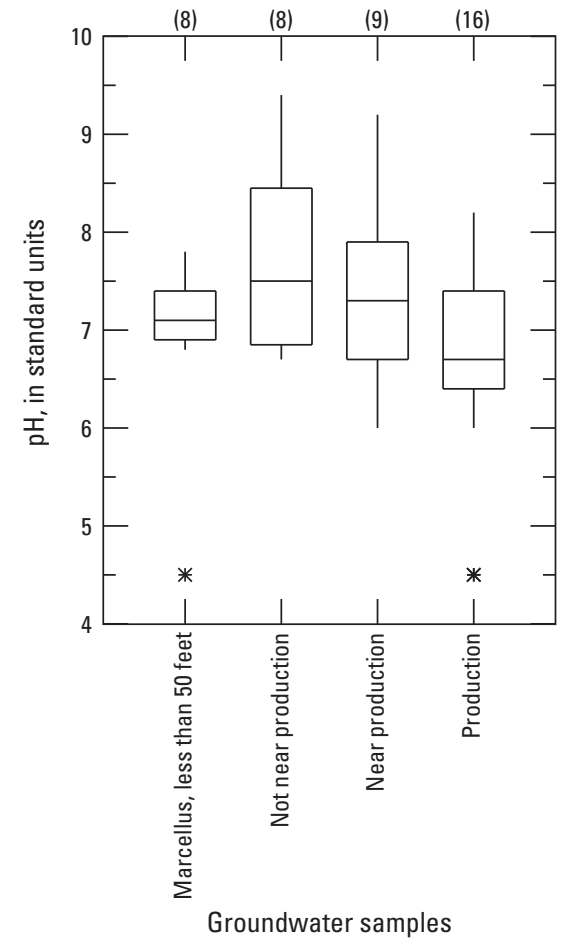

$B$

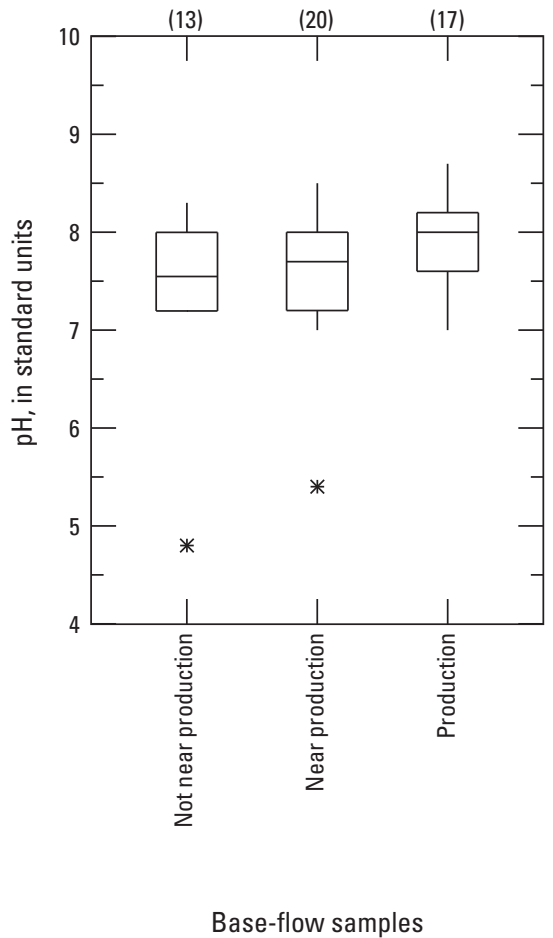

EXPLANATION

Number of samples

Outlier

1.5 times interquartile range

75th percentile

Median (50th percentile)

25th percentile

-1.5 times interquartile range

Figure 11. Distribution of $\mathrm{pH}$ in samples collected as part of the Marcellus Shale baseline study in the Monongahela River Basin, West Virginia, 2011-12: $A$, groundwater samples and $B$, base-flow samples.

samples with a specific cation or anion constituting more than one-half the total cations or anions can be classified by water type, calcium-carbonate type water for example (Hem, 1985). However, waters in which no single cation or anion constitutes greater than one-half of the total cations or anions are classed as mixed-type waters (Hem, 1985).

Major-ion composition of the water for the 41 groundwater samples was predominantly either a calcium-bicarbonate type or a sodium-bicarbonate type (fig. 12A). A few wells exhibited other signatures, however, including 3 wells ( 2 completed in the Pottsville Group and one in the Kanawha Formation) that exhibited a calcium-sulfate signature and 1 well (completed in the Allegheny Formation) that exhibited a sodium-sulfate signature. Wells completed in the Greenbrier Group exhibited a strong calcium-bicarbonate signature, which is expected because the Greenbrier Limestone is a significant karst bedrock-forming unit in the study area.

The major ion composition of the groundwater survey samples (fig. 12A) is similar to that found in a study of groundwater downgradient from reclaimed surface mines and in unmined areas in Pennsylvania and West Virginia (McAuley and Kozar, 2006), part of which was conducted in the Monongahela River Basin. In that study, median chloride concentrations for mined and un-mined areas were $5.1 \mathrm{mg} / \mathrm{L}$ and $7.3 \mathrm{mg} / \mathrm{L}$, respectively; median sodium concentrations for mined and unmined areas were $9.35 \mathrm{mg} / \mathrm{L}$ and $18.0 \mathrm{mg} / \mathrm{L}$, respectively. Median calcium concentrations for mined and unmined areas were $35.9 \mathrm{mg} / \mathrm{L}$ and $21.0 \mathrm{mg} / \mathrm{L}$, respectively, and median magnesium concentrations for mined and unmined areas were $9.9 \mathrm{mg} / \mathrm{L}$ and $4.4 \mathrm{mg} / \mathrm{L}$, respectively. Median chloride concentrations for wells sampled as part of the current study were slightly higher (table 4) at $9.42 \mathrm{mg} / \mathrm{L}$.

Salt waters and brines are found as shallow as 300 feet below land surface in certain valleys in Pennsylvanian- and Permian-aged aquifers (Wilmoth, 1975). Chloride and bromide concentrations can be indicative of salt waters and brines. Chloride concentrations in groundwater survey samples ranged from $0.57 \mathrm{mg} / \mathrm{L}$ to $67.6 \mathrm{mg} / \mathrm{L}$ with a median value of $9.42 \mathrm{mg} / \mathrm{L}$, and bromide ranged from less than the reporting level of $0.010 \mathrm{mg} / \mathrm{L}$ to $0.598 \mathrm{mg} / \mathrm{L}$ with a median value of $0.027 \mathrm{mg} / \mathrm{L}$. The relative concentrations of chloride and bromide can be used to characterize sources of salt waters and brines because bromide concentrations are greater than chloride concentrations in deep brines (Hem, 1985). 

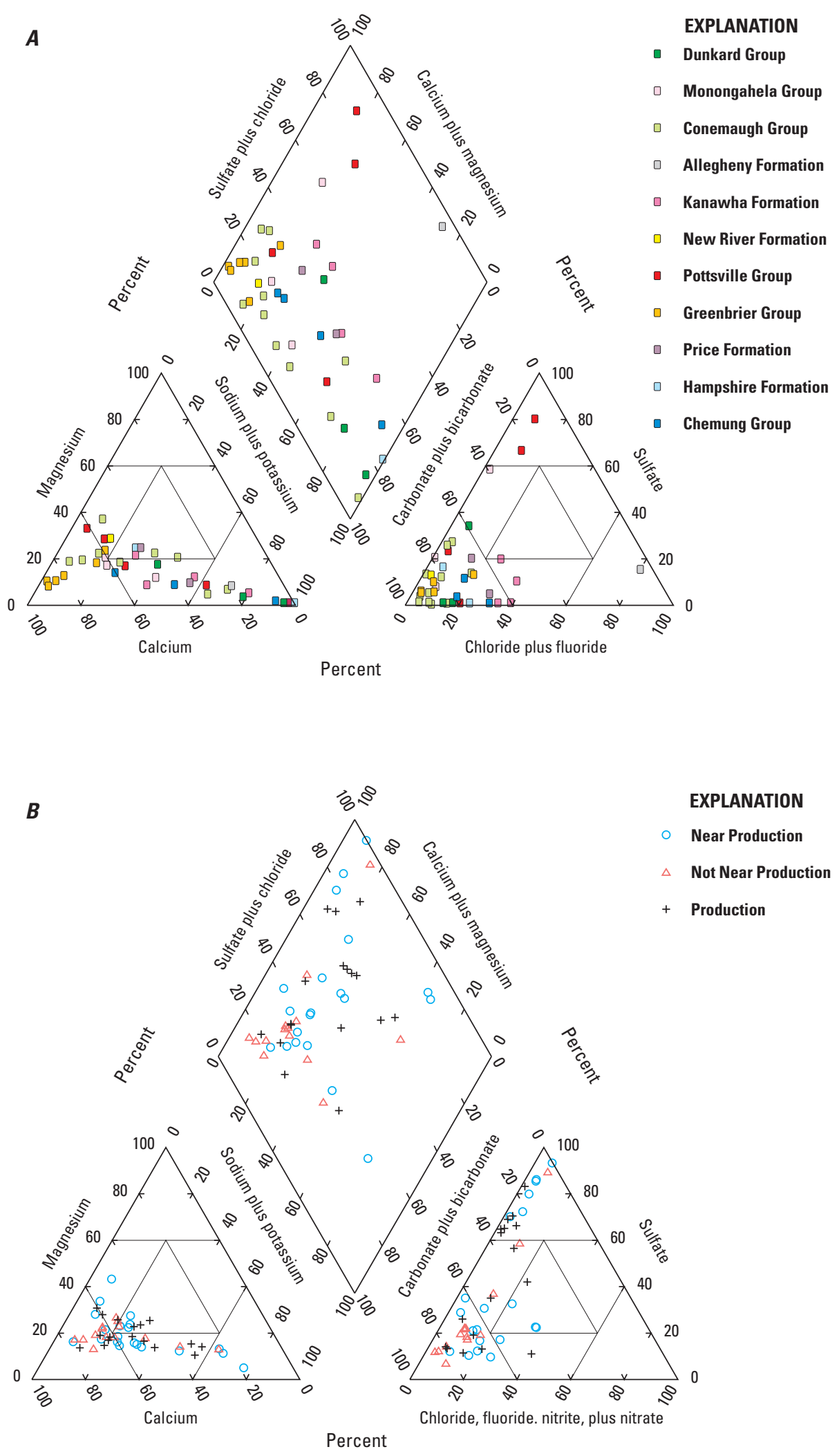

Figure 12. Piper diagrams showing major ion composition of samples collected as part of the Marcellus Shale baseline study, 2011-12, from the Monongahela River Basin, West Virginia: $A$, groundwater survey samples classified by geologic formation and $B$, base-flow survey samples. 
Chloride concentrations did not vary significantly among the gas-production bins (Kruskal-Wallis test, $\mathrm{p}=0.169$ ). Bromide concentrations in groundwater survey samples were significantly higher in the Near Production bin than in the other bins (Kruskal-Wallis test, $\mathrm{p}=0.058$ ). Although the concentrations of the chloride and bromide may indicate potential mixing of shallow groundwater with deeper saline or brine waters, it takes very little saline water or brine to impart a brine signature (Llewellyn, 2014).

Most of the samples from the 2012 base-flow survey were either calcium-carbonate or calcium-sulfate type waters (fig. 12B). The remainder of samples were mostly either sodium-carbonate or sodium-sulfate type waters. Although samples from Production bins accounted for most of the calcium-sulfate waters, there was no clear pattern of watertype distribution among the bins.
With the exception of chloride in base-flow-survey samples, no significant differences were noted in a comparison of historical data with either groundwater survey or the baseflow survey data (fig. 13). Chloride was significantly higher in the 2012 base-flow survey samples than in the historical data from the Monongahela River Basin (Kruskal-Wallis test, $p<0.01$ ). As noted in the discussion of ionic composition of groundwater survey samples, increased chloride concentration may be related to the presence of saline waters or brines from deep aquifers.

A comparison of major-ion concentrations among the Production, Near Production, and Not Near Production bins revealed no significant differences with the exception of fluoride (fig. 14). Fluoride concentrations in the Production bin were significantly higher than concentrations in either the Near Production or Not Near Production bins (Kruskal-Wallis test, $p=0.0416$, fig. $13 \mathrm{H}$ ).
A
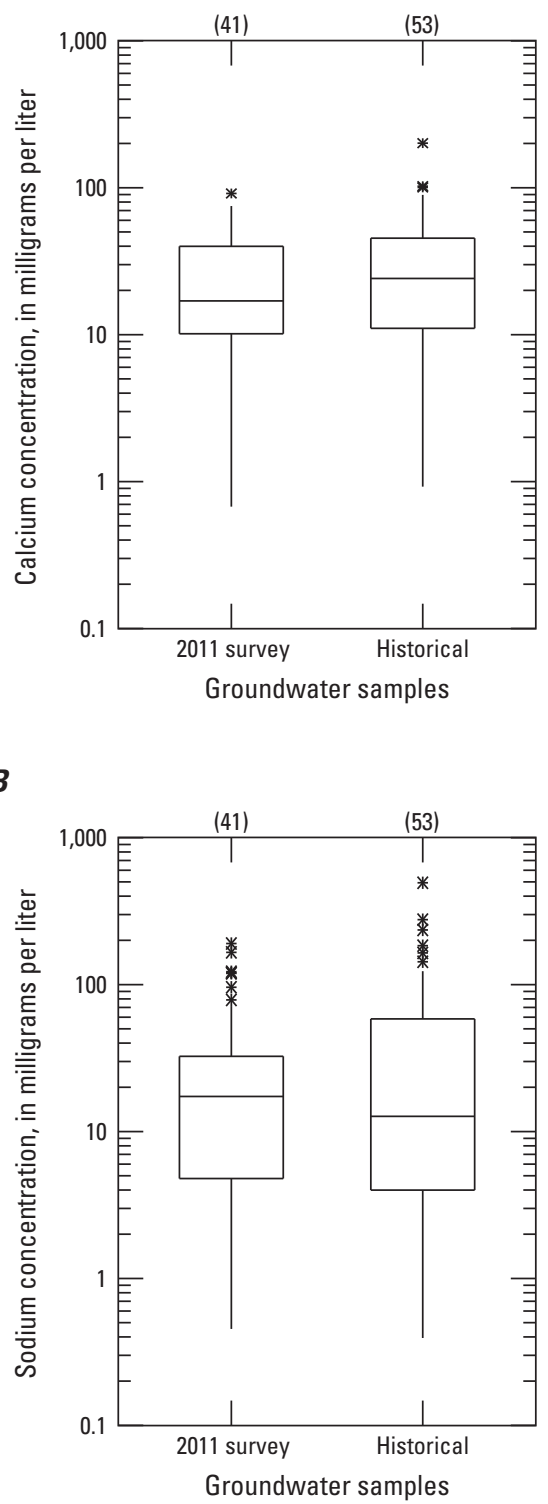
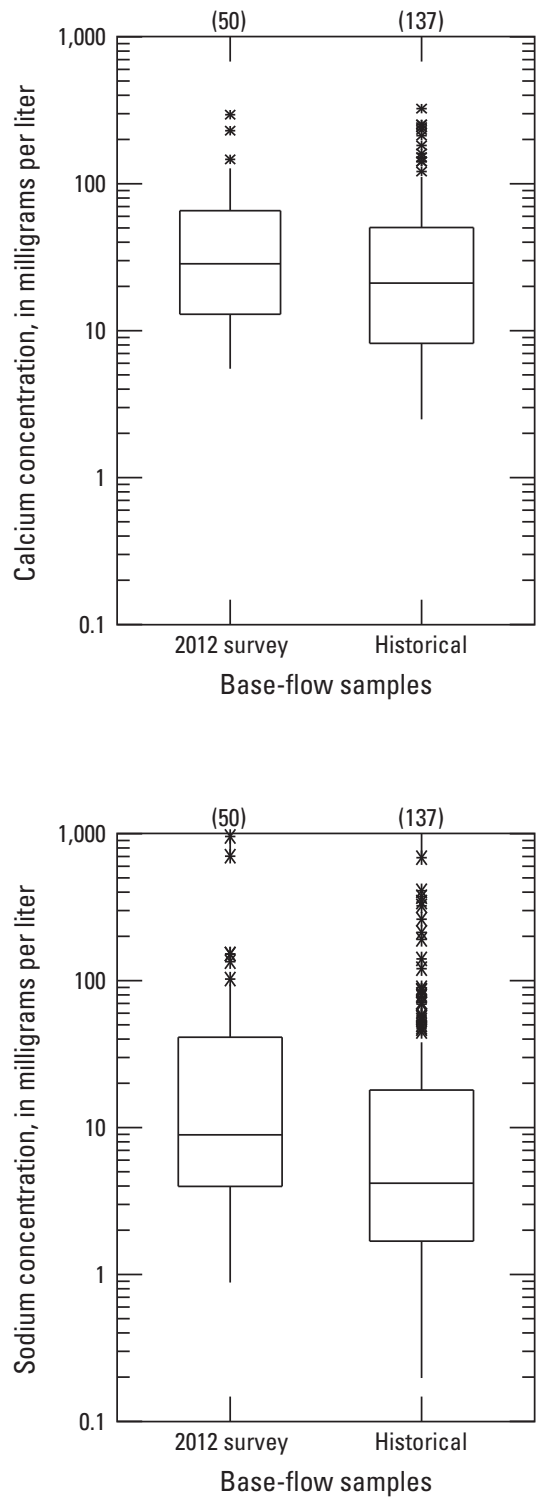

EXPLANATION

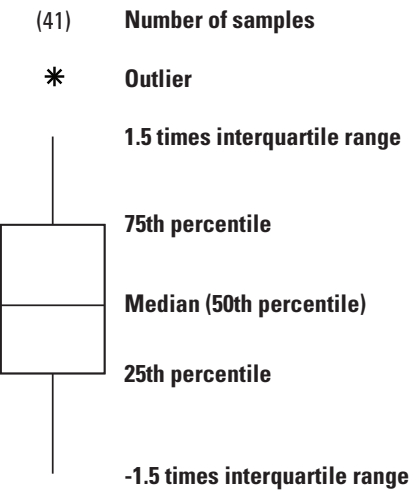

Figure 13. Distribution of majorion concentrations in groundwater and base-flow samples collected as part of the Marcellus Shale baseline study, 2011-12, and historical majorion concentrations, Monongahela River Basin, West Virginia: $A$, calcium, $B$, sodium, $C$, magnesium, $D$, potassium, $E$, chloride, $F$, sulfate, $G$, bromide, and $H$, fluoride. 
C

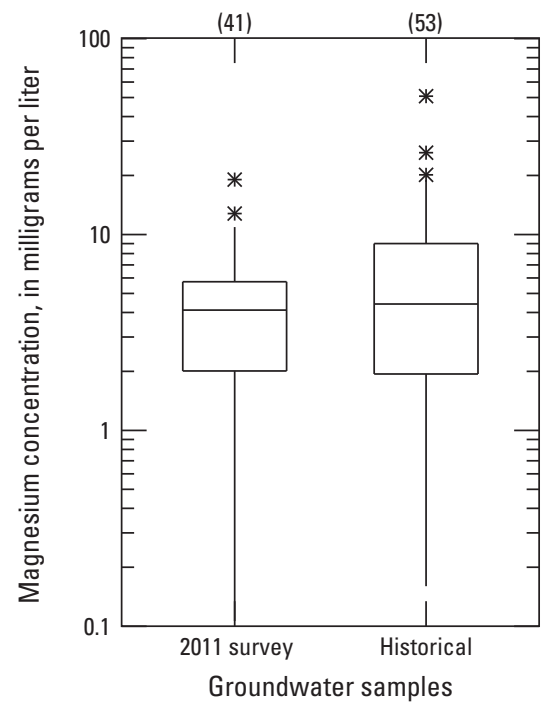

D

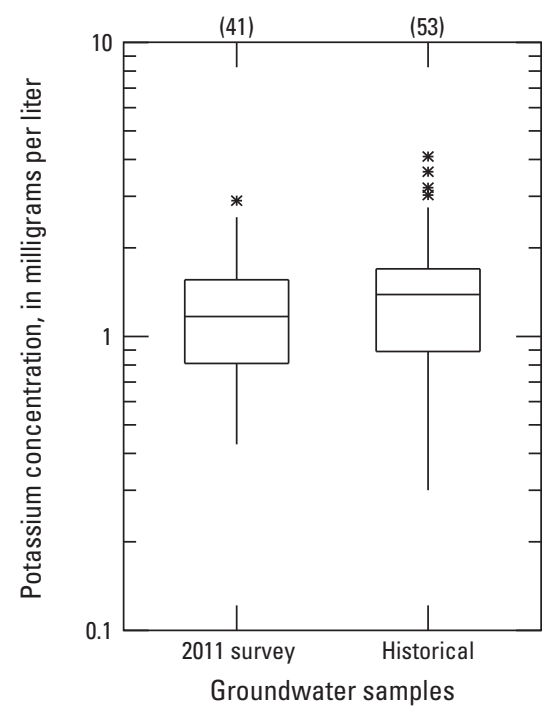

E

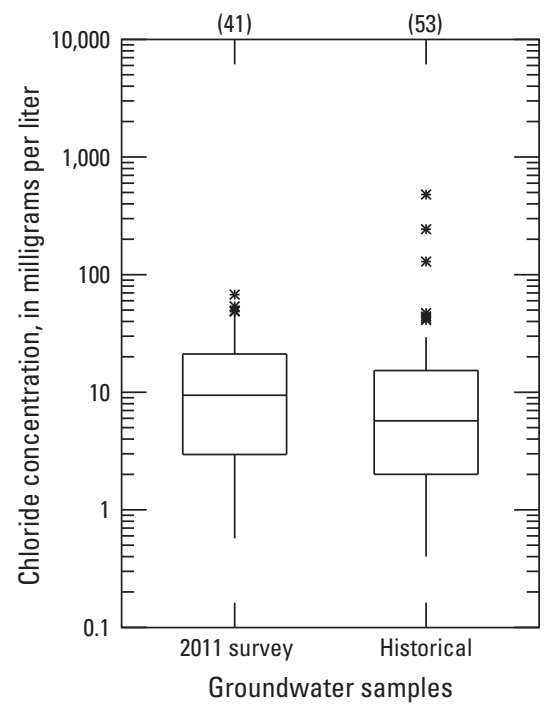

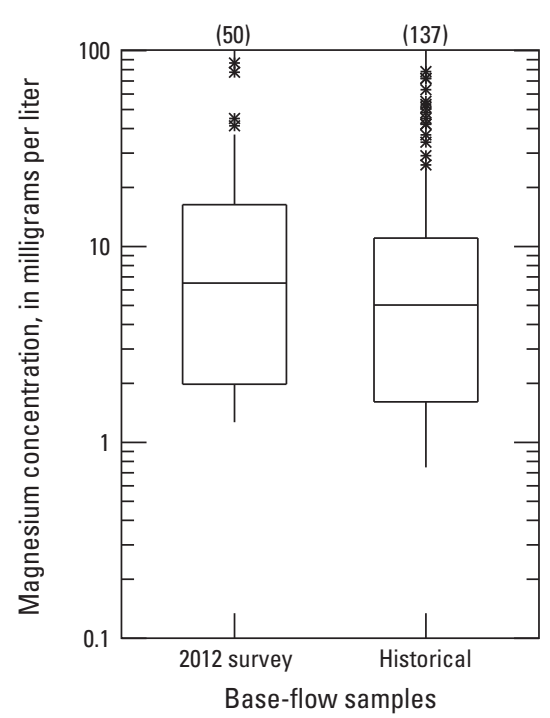
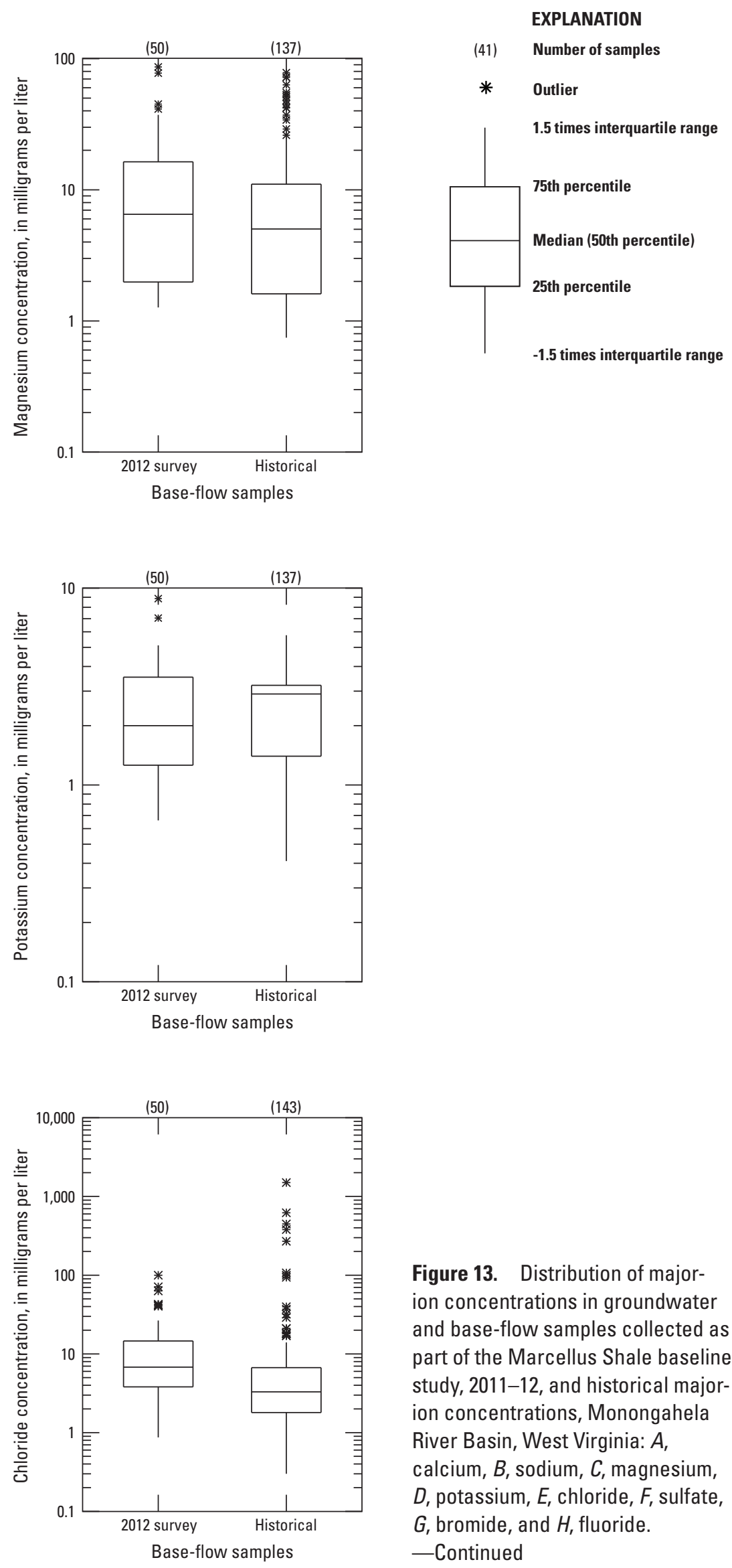

Figure 13. Distribution of majorion concentrations in groundwater and base-flow samples collected as part of the Marcellus Shale baseline study, 2011-12, and historical majorion concentrations, Monongahela River Basin, West Virginia: $A$, calcium, $B$, sodium, $C$, magnesium, $D$, potassium, $E$, chloride, $F$, sulfate, $G$, bromide, and $H$, fluoride.

-Continued 


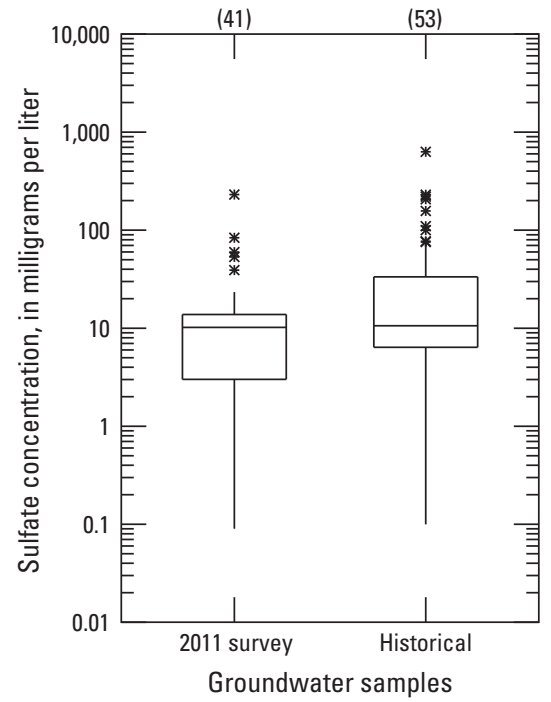

G

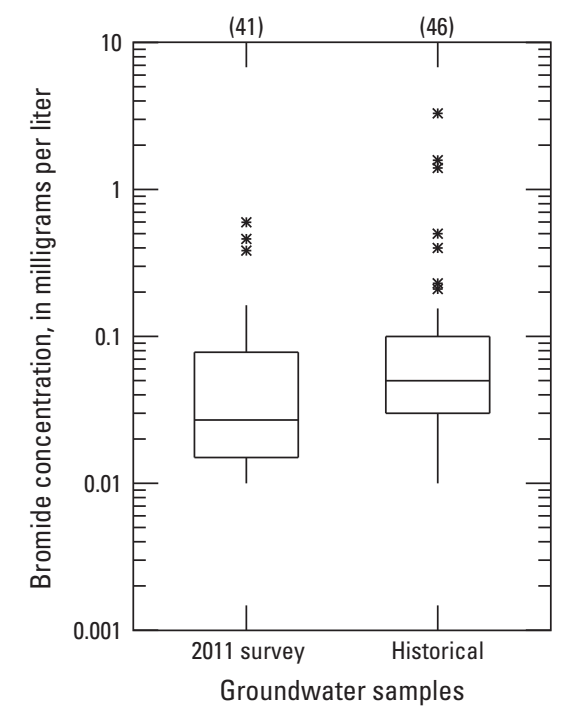

H

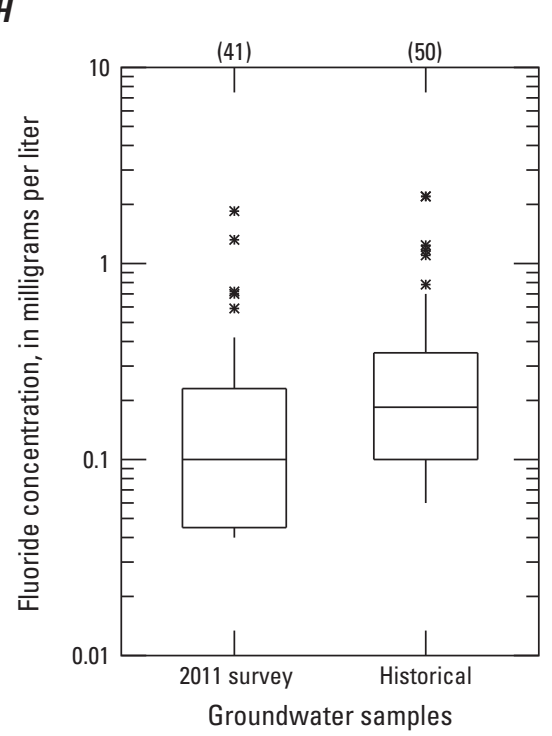

$H$

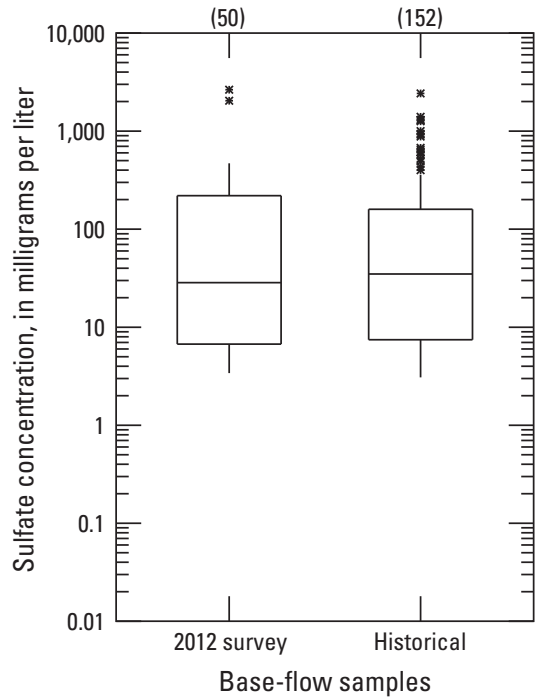

(41) Number of samples

* Outlier

1.5 times interquartile range

75th percentile

Median (50th percentile)

25th percentile

-1.5 times interquartile range
Figure 13. Distribution of majorion concentrations in groundwater and base-flow samples collected as part of the Marcellus Shale baseline study, 2011-12, and historical majorion concentrations, Monongahela River Basin, West Virginia: $A$, calcium, $B$, sodium, $C$, magnesium, $D$, potassium, $E$, chloride, $F$, sulfate, $G$, bromide, and $H$, fluoride. -Continued 
A
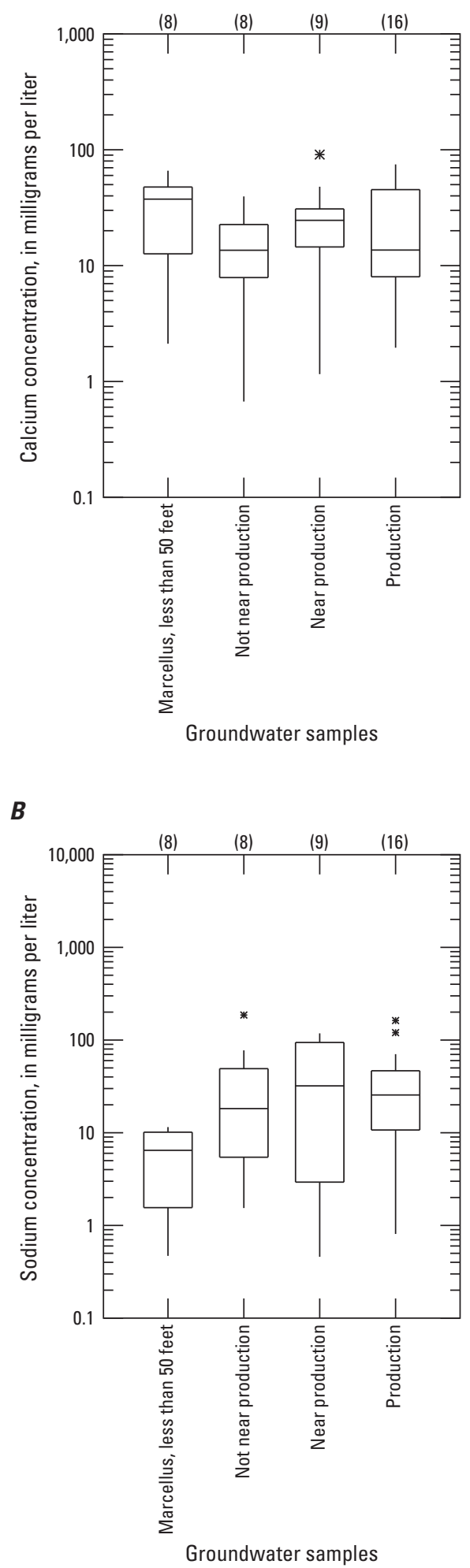
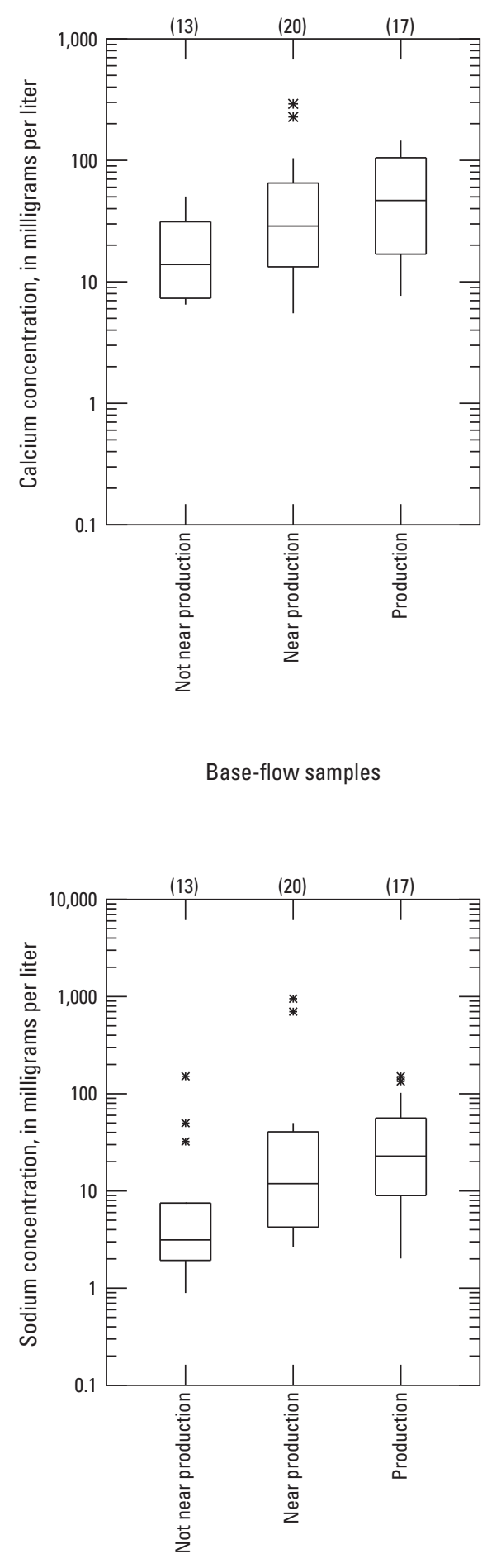

Base-flow samples
EXPLANATION

(8) Number of samples

* Outlier

1.5 times interquartile range

75th percentile

Median (50th percentile)

25th percentile

-1.5 times interquartile range
Figure 14. Distribution of major-ion concentrations in groundwater and base-flow samples collected as part of the baseline study, Monongahela River Basin, West Virginia, 2011-12, grouped by gas production bin: $A$, calcium, $B$, sodium, $C$, magnesium, $D$, potassium, $E$, chloride, $F$, sulfate, $G$, bromide, and $H$, fluoride. 
C

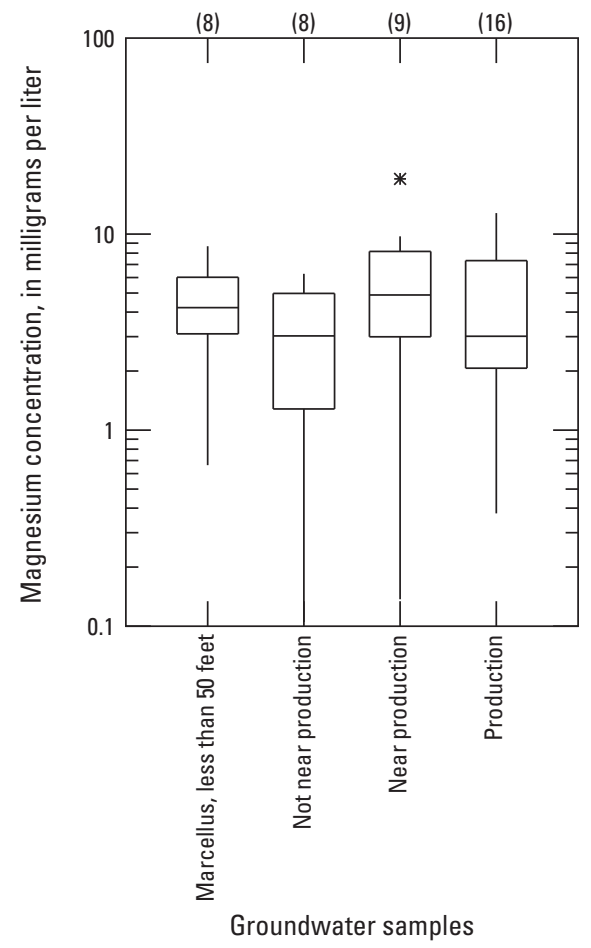

EXPLANATION

(8) Number of samples

* Outlier

1.5 times interquartile range

75th percentile

Median (50th percentile)

25th percentile

-1.5 times interquartile range
D

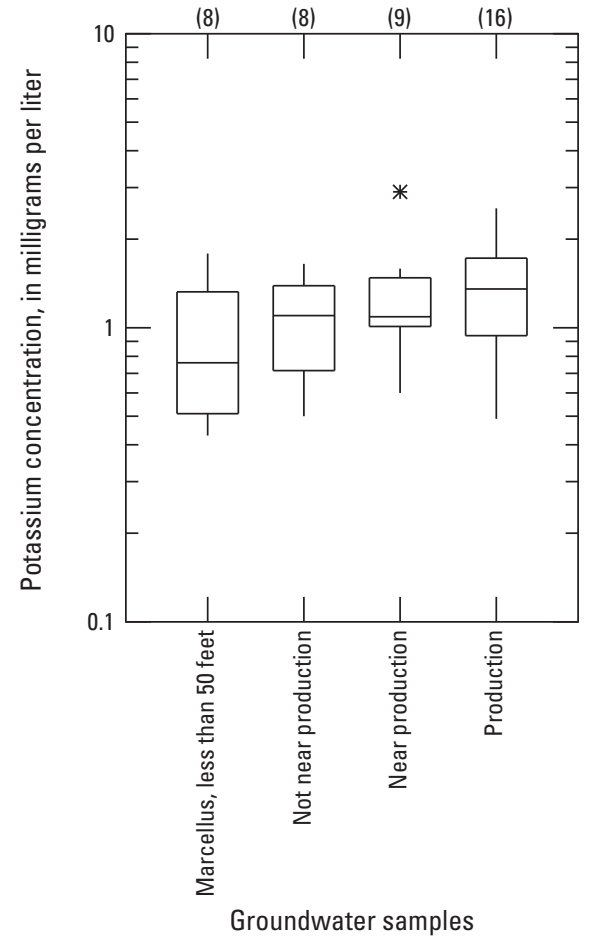

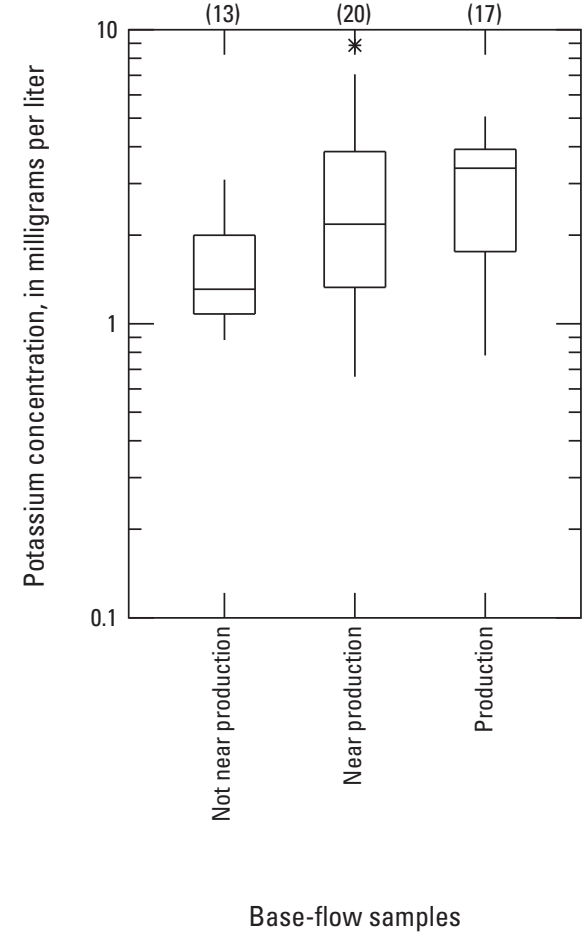

Figure 14. Distribution of major-ion concentrations in groundwater and base-flow samples collected as part of the baseline study, Monongahela River Basin, West Virginia, 2011-12, grouped by gas production bin: $A$, calcium, $B$, sodium, $C$, magnesium, $D$, potassium, $E$, chloride, $F$, sulfate, $G$, bromide, and $H$, fluoride. 
E
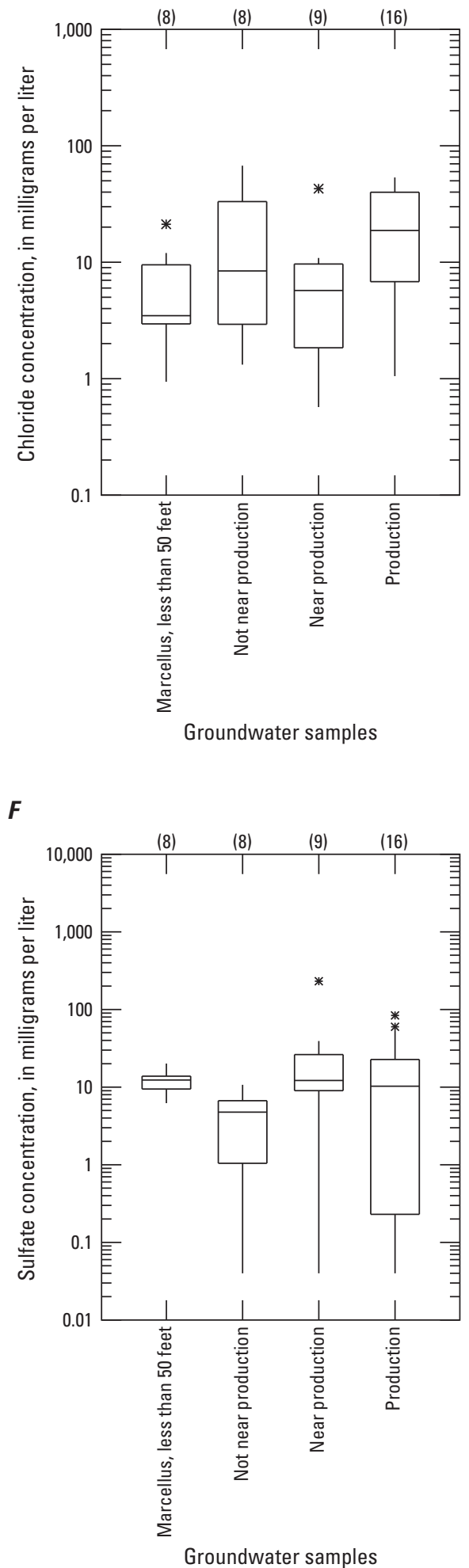
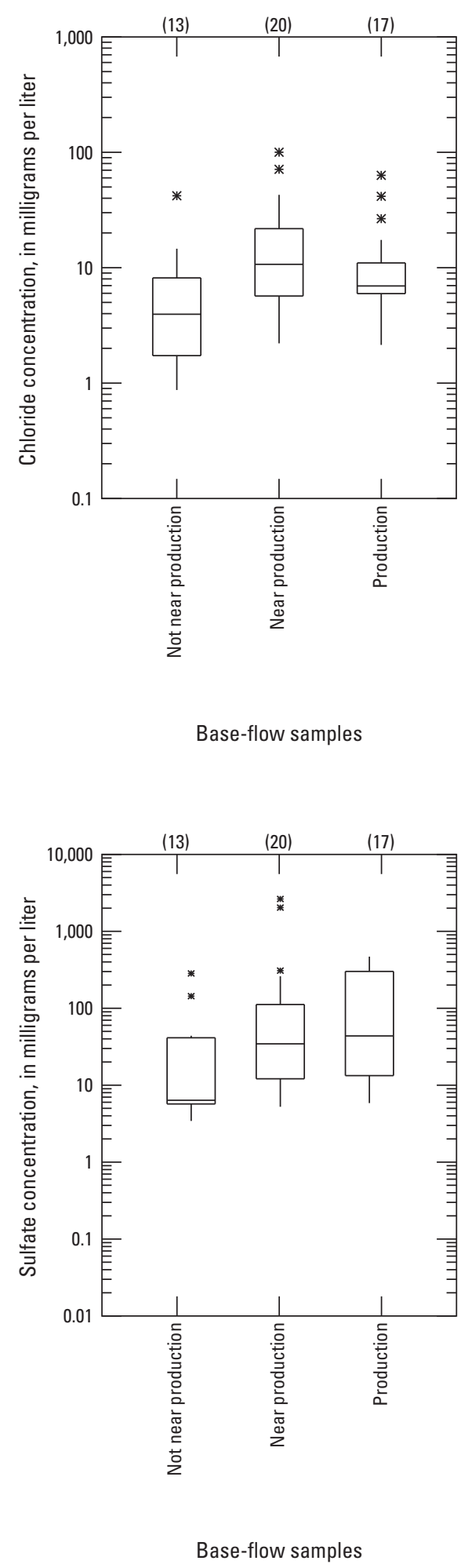

EXPLANATION

(8) Number of samples

* Outlier

1.5 times interquartile range

75th percentile

Median (50th percentile)

25th percentile

-1.5 times interquartile range
Figure 14. Distribution of major-ion concentrations in groundwater and base-flow samples collected as part of the baseline study, Monongahela River Basin, West Virginia, 2011-12, grouped by gas production bin: $A$, calcium, $B$, sodium, $C$, magnesium, $D$, potassium, $E$, chloride, $F$, sulfate, $G$, bromide, and $H$, fluoride. 

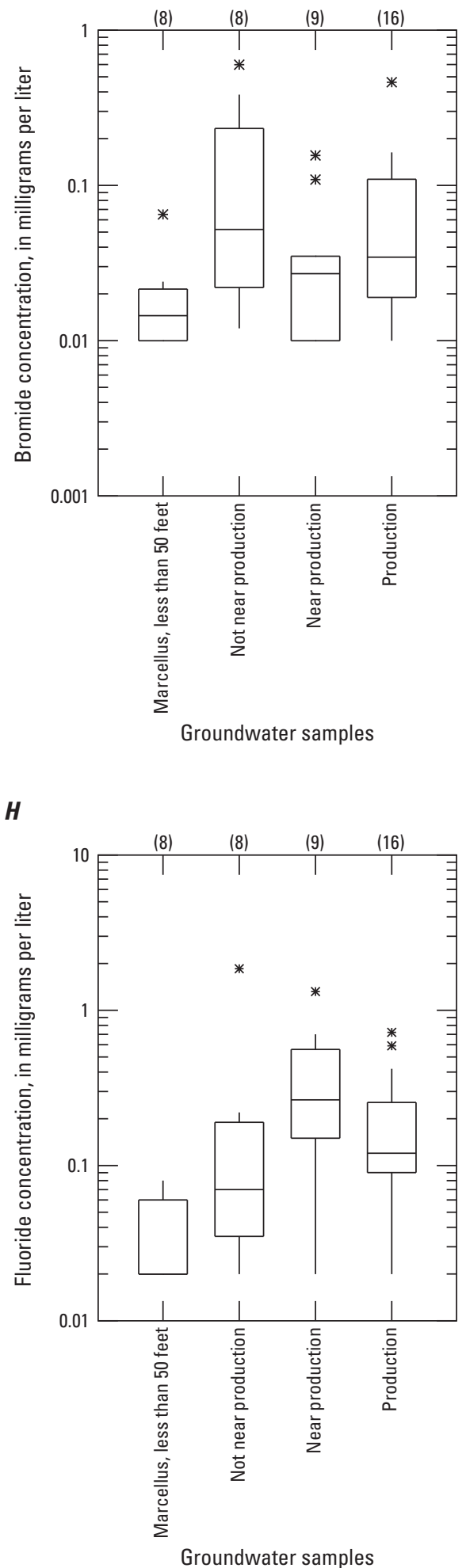
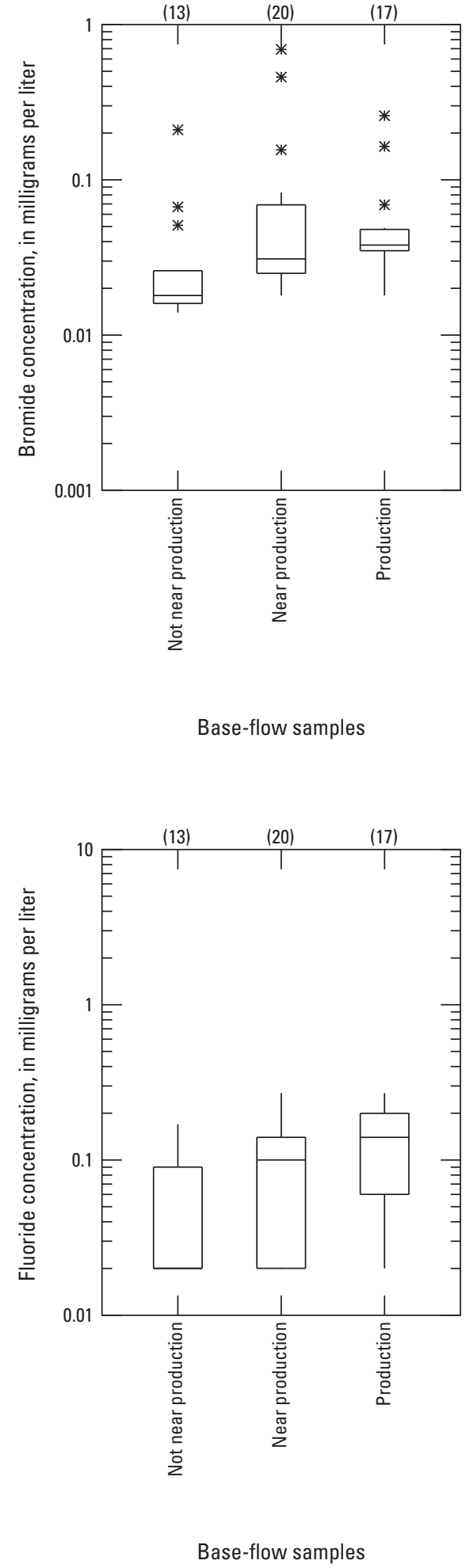

EXPLANATION

(8) Number of samples

* Outlier

1.5 times interquartile range

75th percentile

Median (50th percentile)

25th percentile

-1.5 times interquartile range
Figure 14. Distribution of major-ion concentrations in groundwater and base-flow samples collected as part of the baseline study, Monongahela River Basin, West Virginia, 2011-12, grouped by gas production bin: $A$, calcium, $B$, sodium, $C$, magnesium, $D$, potassium, $E$, chloride, $F$, sulfate, $G$, bromide, and $H$, fluoride. 


\section{Trace Elements}

Trace elements are those constituents that are commonly found in waters at concentrations less than $1.0 \mathrm{mg} / \mathrm{L}$ (Hem, 1985). The presence or absence of certain trace elements can provide insight into the origin and composition of sampled waters. In the groundwater survey and the base-flow survey, several of the trace elements (beryllium, cadmium, chromium, copper, lead, nickel, silver, antimony, and selenium) were infrequently detected and, therefore, are not discussed within this report. Aluminum, iron, manganese, barium, strontium, cobalt, molybdenum, and arsenic were more frequently detected in either groundwater or base-flow survey samples (table 5) and are discussed below.

Aluminum, the third most common crustal element, typically occurs in concentrations less than $0.1 \mathrm{mg} / \mathrm{L}$ in natural waters (Hem, 1985). The median aluminum value for groundwater survey samples was less than the laboratory reporting level of $1.7 \mu \mathrm{g} / \mathrm{L}$. However, concentrations of aluminum in base-flow survey samples ranged from less than the $2.2 \mu \mathrm{g} / \mathrm{L}$ reporting level to $4,420 \mu \mathrm{g} / \mathrm{L}$; the median concentration of aluminum was $9.1 \mu \mathrm{g} / \mathrm{L}$. Aluminum concentrations in groundwater survey did not differ from historical data. Historical data were insufficient for a comparison with base-flow survey data. Aluminum concentrations for these samples did not vary significantly among the gas-production bins (figs. 15 and 16).

Iron and manganese are common constituents of groundwater in the study area. Both usually occur in natural waters as a trace element (Hem, 1985). The oxidation of pyrite (iron sulfide) or less commonly siderite (iron carbonate) minerals in bedrock of the region are a major source of iron in West Virginia's waters. Iron concentrations in groundwater survey samples ranged from less than the reporting level of $3.2 \mu \mathrm{g} / \mathrm{L}$ to $11,600 \mu \mathrm{g} / \mathrm{L}$ with a median of $84 \mu \mathrm{g} / \mathrm{L}$. This median concentration is similar to that found for wells from unmined parts of the Allegheny and Monongahela River Basins sampled as part of a mining land-use assessment (McAuley and Kozar, 2006). Iron concentrations from the groundwater survey did not differ significantly from historical data (fig. 15B). Iron concentrations in base-flow survey samples ranged from less than the reporting level of $3.2 \mu \mathrm{g} / \mathrm{L}$ to $1,040 \mu \mathrm{g} / \mathrm{L}$ with a median concentration of $32.6 \mu \mathrm{g} / \mathrm{L}$. Results from the 2012 base-flow survey did not differ significantly from historical data for the Monongahela River Basin (fig. 15B), nor did iron concentrations in either groundwater or base-flow survey samples vary significantly among the gas-production bins (fig. 16B).

The presence of manganese in the waters of West Virginia is associated with coal mining. In the groundwater samples, manganese concentrations ranged from less than a reporting level of $0.13 \mu \mathrm{g} / \mathrm{L}$ to $1,670 \mu \mathrm{g} / \mathrm{L}$ with a median concentration of $84.9 \mu \mathrm{g} / \mathrm{L}$. The median value for manganese compared well with the median concentration for wells in unmined parts of the Allegheny and Monongahela River Basins, $94 \mu \mathrm{g} / \mathrm{L}$ (McAuley and Kozar, 2006), and the groundwater survey manganese concentrations did not differ significantly from historical data (fig. 15C). Manganese concentrations in the base-flow samples ranged from $1.66 \mu \mathrm{g} / \mathrm{L}$ to $473 \mu \mathrm{g} / \mathrm{L}$ with a median concentration of $26.8 \mu \mathrm{g} / \mathrm{L}$. Manganese concentrations in samples from the base-flow survey did not differ significantly from historical values (fig. 15C). Among base-flow samples, manganese concentrations were significantly lower in the Not Near Production bin than either the Production or Near Production bins (Kruskal-Wallis test, $\mathrm{p}=0.006$ ). Groundwater samples did not vary significantly among the gas-production bins (Kruskal-Wallis test, $\mathrm{p}=0.383$ ) (fig. 16C).

The EPA SMCL, guidelines established on the basis of aesthetic effects, have been developed for iron and manganese in domestic water because they can stain laundry and plumbing fixtures. Iron and manganese concentrations exceeded EPA SMCL drinking water standards of $300 \mu \mathrm{g} / \mathrm{L}$ and $50 \mu \mathrm{g} / \mathrm{L}$, respectively, in 46 percent ( 19 of 41 ) and 59 percent ( 24 of 41) of the groundwater samples for this study.

Barium is a relatively abundant element; the dissolution of the common mineral barite (barium sulfate) is the chief source of barium in water. Barium is considered to be a common constituent of deeper brines in the study area (Engle and Rowan, 2013). The median concentration in the groundwater-survey samples was $207 \mu \mathrm{g} / \mathrm{L}$ with a concentration range of $22.1-1,400 \mu \mathrm{g} / \mathrm{L}$. Barium concentrations in the groundwater survey did not differ significantly from historical data (fig. 15D). The median concentration of barium in the base-flow survey samples was $51.7 \mu \mathrm{g} / \mathrm{L}$, with concentrations ranging from $18.1 \mu \mathrm{g} / \mathrm{L}$ to $98.4 \mu \mathrm{g} / \mathrm{L}$. The 2012 base-flow survey barium concentrations did not differ significantly from historical concentrations of barium (fig. 15D). Among the gasproduction bins, barium concentrations in base-flow samples were significantly higher (Kruskal-Wallis test, $p=0.0487$ ) in the Production bin than in either the Near Production bin or the Not Near Production bin (fig. 16D).

Strontium geochemistry is similar to that of calcium (Hem, 1985), and like barium, strontium is considered a common constituent of deeper brines in the study area (Engle and Rowan, 2013). The median concentration of strontium in the groundwater survey samples was $176 \mu \mathrm{g} / \mathrm{L}$, with a concentration range of $9.6-787 \mu \mathrm{g} / \mathrm{L}$. Strontium concentrations in baseflow survey samples ranged from $23.6 \mu \mathrm{g} / \mathrm{L}$ to $4,470 \mu \mathrm{g} / \mathrm{L}$ with a median concentration of $117 \mu \mathrm{g} / \mathrm{L}$. Historical strontium data for groundwater samples were insufficient to make comparisons with samples collected as part of this study. Data were available for the base-flow samples, and concentrations in the base-flow survey samples were significantly higher than concentrations in the historical data for West Virginia's Monongahela River Basin (Kruskal-Wallis test, $\mathrm{p}<0.01$ ) (fig. 15E). Strontium concentrations did not vary significantly among gas-production bins (fig. 16E).

Median cobalt concentrations in samples from the groundwater survey and the base-flow survey were $0.091 \mu \mathrm{g} / \mathrm{L}$ and $0.420 \mu \mathrm{g} / \mathrm{L}$, respectively. Historical cobalt data were 
Table 5. Statistical summary of trace elements in samples collected for the groundwater survey and the base-flow survey as part of the Marcellus Shale baseline survey, West Virginia, 2011-12.

$[\mu \mathrm{g} / \mathrm{L}$, micrograms per liter; wf, filtered water sample; <, less than; MCL, maximum contaminant level (U.S. Environmental Protection Agency, 2009), SMCL, secondary maximum contaminant level (U.S. Environmental Protection Agency, 2009); TT, treatment technique action level (U.S. Environmental Protection Agency, 2009); NA, not applicable]

\begin{tabular}{|c|c|c|c|c|c|c|c|}
\hline Trace element & $\begin{array}{c}\text { Method } \\
\text { reporting level }\end{array}$ & Survey & $\begin{array}{c}\text { Minimum } \\
\text { concentration }\end{array}$ & $\begin{array}{c}\text { Maximum } \\
\text { concentration }\end{array}$ & $\begin{array}{c}\text { Median } \\
\text { concentration }\end{array}$ & MCL or TT & SMCL \\
\hline \multirow{2}{*}{ Aluminum, wf, $\mu \mathrm{g} / \mathrm{L}$} & \multirow{2}{*}{$1.7-6.6$} & Groundwater & $<1.7$ & 979 & $<1.7$ & \multirow{2}{*}{ NA } & \multirow{2}{*}{200} \\
\hline & & Base flow & $<2.2$ & 4,420 & 9.1 & & \\
\hline \multirow{2}{*}{ Iron, wf, $\mu \mathrm{g} / \mathrm{L}$} & \multirow{2}{*}{3.2} & Groundwater & $<3.2$ & 11,600 & 84 & \multirow{2}{*}{ NA } & \multirow{2}{*}{300} \\
\hline & & Base flow & $<3.2$ & 1,040 & 32.6 & & \\
\hline \multirow{2}{*}{ Manganese, wf, $\mu \mathrm{g} / \mathrm{L}$} & \multirow{2}{*}{$0.4-0.13$} & Groundwater & $<0.13$ & 1,670 & 84.9 & \multirow{2}{*}{ NA } & \multirow{2}{*}{50} \\
\hline & & Base flow & 1.66 & 473 & 26.8 & & \\
\hline \multirow{2}{*}{ Barium, wf, $\mu \mathrm{g} / \mathrm{L}$} & \multirow{2}{*}{0.07} & Groundwater & 22.1 & 1,400 & 207 & \multirow{2}{*}{2,000} & \multirow{2}{*}{ NA } \\
\hline & & Base flow & 18.1 & 98.4 & 51.7 & & \\
\hline \multirow{2}{*}{ Strontium, wf, $\mu \mathrm{g} / \mathrm{L}$} & \multirow{2}{*}{$0.2-0.8$} & Groundwater & 9.6 & 787 & 176 & \multirow{2}{*}{ NA } & \multirow{2}{*}{ NA } \\
\hline & & Base flow & 23.6 & 4,470 & 117 & & \\
\hline \multirow{2}{*}{ Cobalt, wf, $\mu \mathrm{g} / \mathrm{L}$} & \multirow{2}{*}{0.02} & Groundwater & $<0.02$ & 9.48 & 0.091 & \multirow{2}{*}{ NA } & \multirow{2}{*}{ NA } \\
\hline & & Base flow & $<0.02$ & 20.6 & 0.420 & & \\
\hline \multirow{2}{*}{ Molybdenum, wf, $\mu \mathrm{g} / \mathrm{L}$} & \multirow{2}{*}{0.014} & Groundwater & $<0.014$ & 2.4 & 0.154 & \multirow{2}{*}{ NA } & \multirow{2}{*}{ NA } \\
\hline & & Base flow & $<0.014$ & 2.21 & 0.232 & & \\
\hline & & Groundwater & $<0.02$ & 6.3 & 0.35 & & \\
\hline Arsenic, wf, $\mu \mathrm{g} / \mathrm{L}$ & $0.02-0.10$ & Base flow & 0.06 & 1.4 & 0.29 & 10 & NA \\
\hline Pervllium wf ur/I & 0006 & Groundwater & $<0.006$ & 0.495 & $<0.006$ & Na & NA \\
\hline Berynlum, w1, $\mu \mathrm{g} / \mathrm{L}$ & 0.006 & Base flow & $<0.006$ & 1.8 & $<0.006$ & NA & NA \\
\hline$C$ d i & 0016 & Groundwater & $<0.016$ & 0.658 & $<0.016$ & 5 & Nat \\
\hline Cadmium, w1, $\mu \mathrm{g} / \mathrm{L}$ & 0.016 & Base flow & $<0.016$ & 0.21 & $<0.016$ & 5 & NA \\
\hline Chromium wf ur/I & $006-007$ & Groundwater & $<0.06$ & 0.75 & $<0.06$ & 100 & NA \\
\hline Chromium, w1, $\mu \mathrm{g} / \mathrm{L}$ & $0.06-0.07$ & Base flow & $<0.07$ & 0.37 & $<0.07$ & 100 & NA \\
\hline Compor & & Groundwater & $<0.5$ & 155 & $<0.5$ & & \\
\hline Copper, wf, $\mu \mathrm{g} / \mathrm{L}$ & $0.5-0.8$ & Base flow & $<0.8$ & 3.7 & $<0.8$ & $1,300 \mathrm{TT}$ & NA \\
\hline & & Groundwater & $<0.015$ & 3.74 & $<0.015$ & $15 \mathrm{TT}$ & NA \\
\hline Lead, wf, $\mu \mathrm{g} / \mathrm{L}$ & $0.015-0.025$ & Base flow & $<0.025$ & 1.21 & 0.034 & $15 \mathrm{TT}$ & NA \\
\hline & & Groundwater & $<0.09$ & 8.1 & 0.19 & & \\
\hline Nickel, wf, $\mu \mathrm{g} / \mathrm{L}$ & 0.09 & Base flow & 0.14 & 34 & 0.75 & NA & NA \\
\hline Silu & 0005 & Groundwater & $<0.005$ & 0.015 & $<0.005$ & NA & 100 \\
\hline Silver, wf, $\mu \mathrm{g} / \mathrm{L}$ & 0.005 & Base flow & $<0.005$ & 0.037 & $<0.005$ & NA & 100 \\
\hline Antimeny wf ur/I & 0027 & Groundwater & $<0.027$ & 0.09 & $<0.027$ & 6 & NA \\
\hline Antımony, w1, $\mu \mathrm{g} / \mathrm{L}$ & & Base flow & $<0.027$ & 0.343 & 0.077 & 6 & \\
\hline & & Groundwater & $<0.03$ & 0.3 & $<0.03$ & & \\
\hline Selenium, wf, $\mu \mathrm{g} / \mathrm{L}$ & 0.03 & Base flow & $<0.03$ & 0.57 & 0.11 & 50 & NA \\
\hline
\end{tabular}

insufficient for comparisons with groundwater and base-flow samples collected as part of this study. Concentrations of cobalt in base-flow survey samples did not vary significantly among gas-production bins (Kruskal-Wallis test, $\mathrm{p}=0.244$ ) (fig. 16F). However, cobalt concentrations in groundwater survey samples varied significantly among gas-production bins (Kruskal-Wallis test, $\mathrm{p}=0.033$ ); concentrations were higher in the Production bin than in the other bins.
Molybdenum is a rare trace element and an essential micronutrient (Hem, 1985). Molybdenum concentrations in the groundwater survey samples ranged from less than the laboratory reporting level of $0.014 \mu \mathrm{g} / \mathrm{L}$ to $2.4 \mu \mathrm{g} / \mathrm{L}$ with a median concentration of $0.154 \mu \mathrm{g} / \mathrm{L}$. The base-flow survey molybdenum concentrations ranged from less than the laboratory reporting level of $0.014 \mu \mathrm{g} / \mathrm{L}$ to $2.21 \mu \mathrm{g} / \mathrm{L}$ with a median concentration of $0.232 \mu \mathrm{g} / \mathrm{L}$. Historical molybdenum data 
were insufficient for comparisons with groundwater or baseflow samples collected as part of this study. Molybdenum concentrations did not vary significantly among gas-production bins (fig. 16G).

Arsenic, a metalloid element, when consumed in drinking water can cause bladder, lung, and skin cancers, and can also be responsible for neurological and cardiovascular effects (National Research Council, 2001; World Health Organization, 2006). Arsenic concentrations in groundwater samples ranged from less than $0.02 \mu \mathrm{g} / \mathrm{L}$ to $6.3 \mu \mathrm{g} / \mathrm{L}$. The median concentration of arsenic in groundwater samples was $0.35 \mu \mathrm{g} / \mathrm{L}$. Arsenic concentrations in the base-flow samples ranged from $0.06 \mu \mathrm{g} / \mathrm{L}$ to $1.4 \mu \mathrm{g} / \mathrm{L}$ The median arsenic concentration for base-flow survey samples was $0.29 \mu \mathrm{g} / \mathrm{L}$. Comparisons of arsenic concentrations from historical data and concentrations in samples from the groundwater and base-flow surveys were complicated by the wide range of reporting levels in the historical data, from $0.18 \mu \mathrm{g} / \mathrm{L}$ to $4.0 \mu \mathrm{g} / \mathrm{L}$, whereas the analyses for the groundwater and base-flow surveys had a reporting limit of $0.02-0.1 \mu \mathrm{g} / \mathrm{L}$. No significant difference was observed among the gas-production bins for groundwater (Kruskal-Wallis test, $\mathrm{p}=0.147$ ) or base-flow samples (Kruskal-Wallis test, $\mathrm{p}=0.638$ ) (fig. 16H). In 2006, the EPA maximum contaminant level (MCL) for total arsenic was lowered from $50 \mu \mathrm{g} / \mathrm{L}$ to $10 \mu \mathrm{g} / \mathrm{L}$ (Federal Register, 2001); no sample from either the groundwater survey or the base-flow survey exceeded the MCL.
A

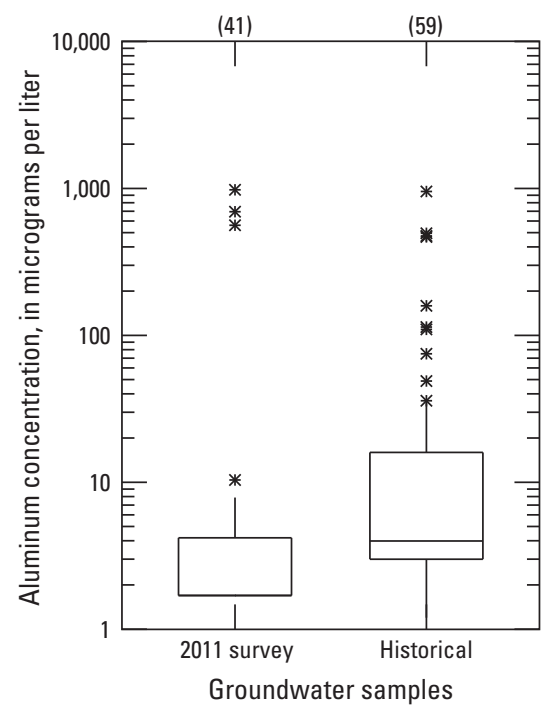

B

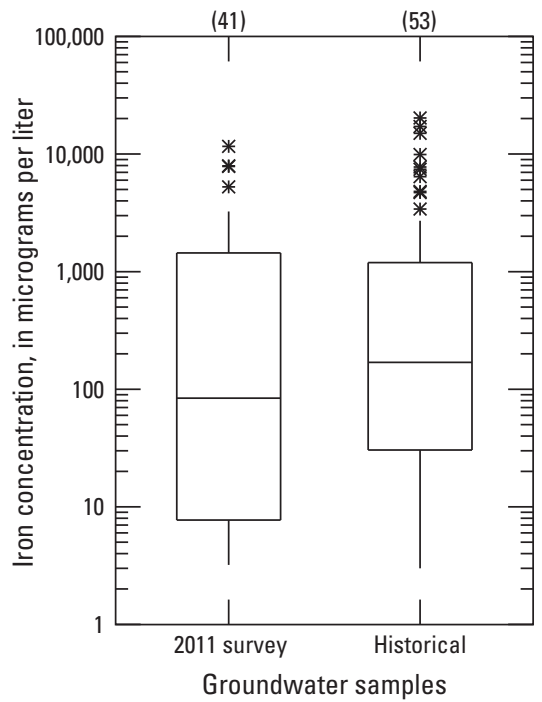

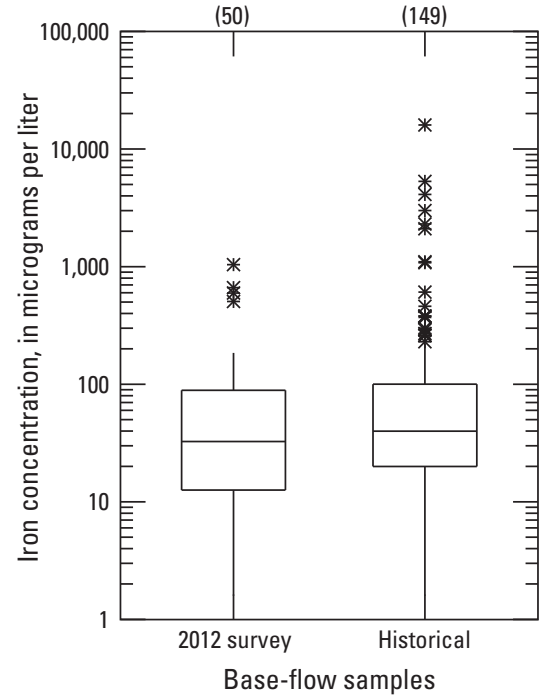

EXPLANATION

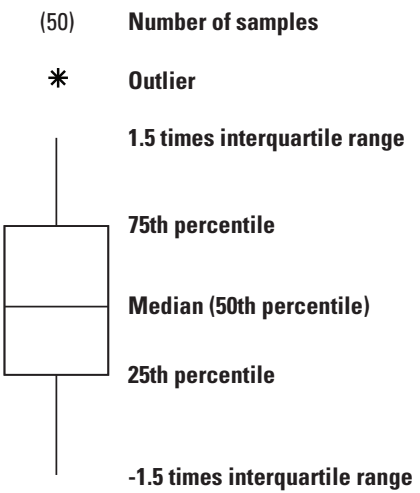

Figure 15. Distribution of trace-element concentrations in groundwater and base-flow samples collected as part of the Marcellus Shale baseline study, 2011-12, and historical trace-element concentrations, Monongahela River Basin, West Virginia: $A$, aluminum, $B$, iron, $C$, manganese, $D$, barium, and $E_{\text {, }}$ strontium in base flow only. 
C

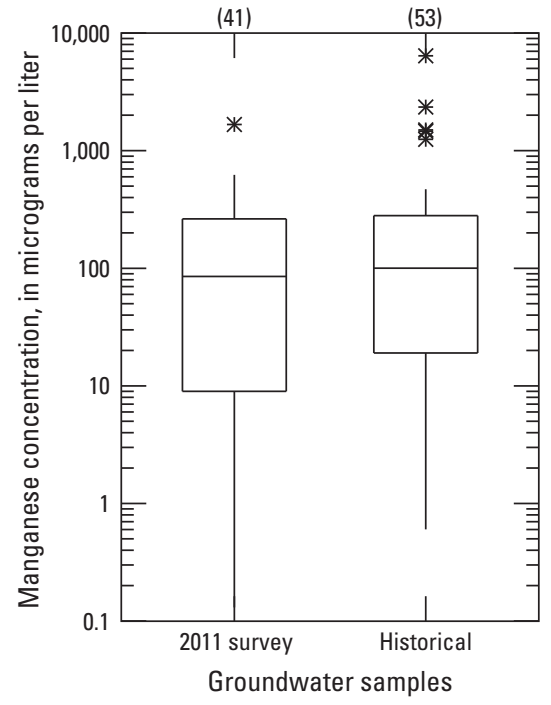

D

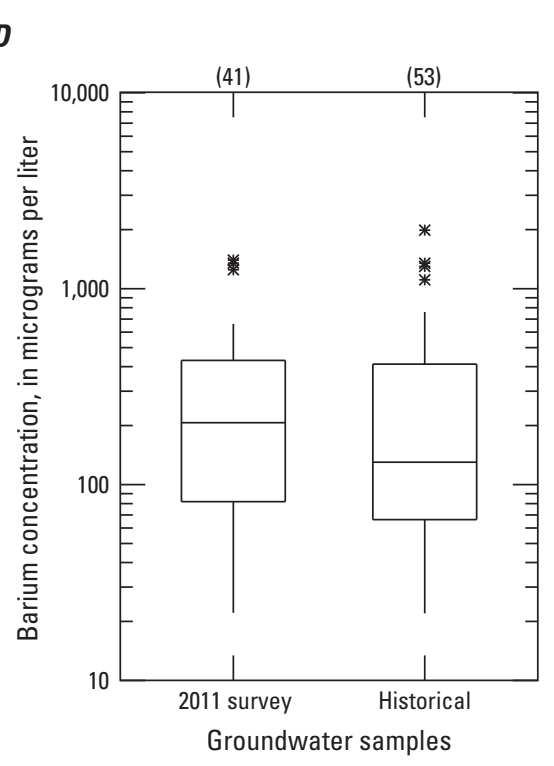

E

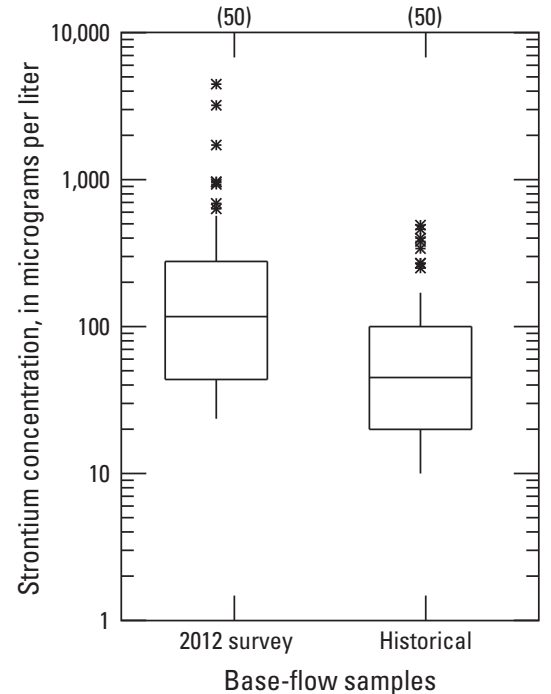

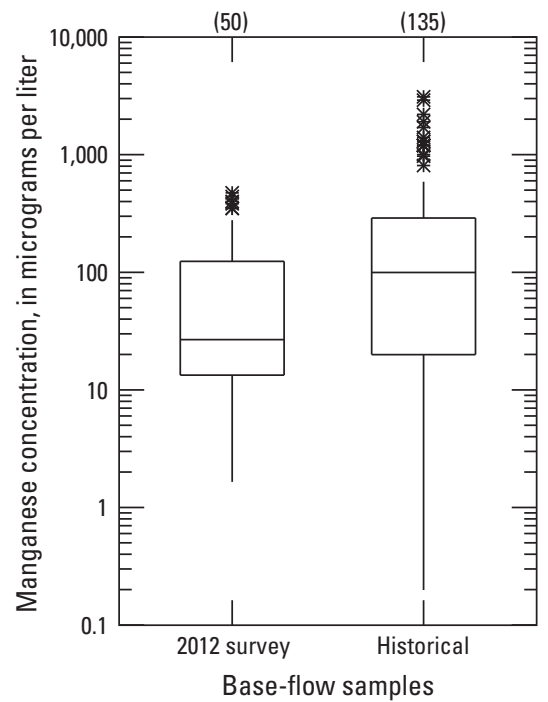

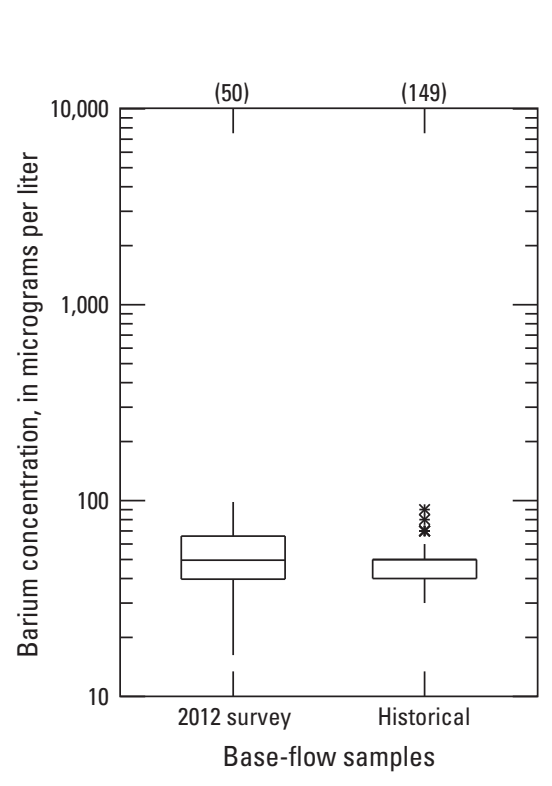

EXPLANATION

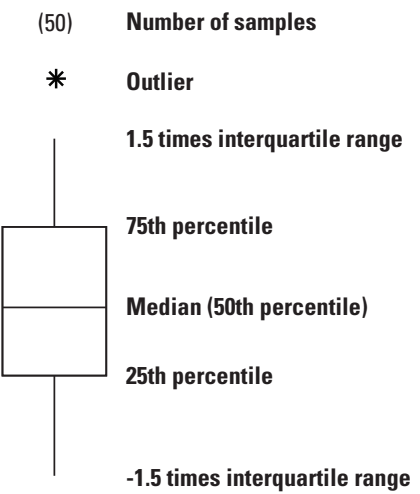


A

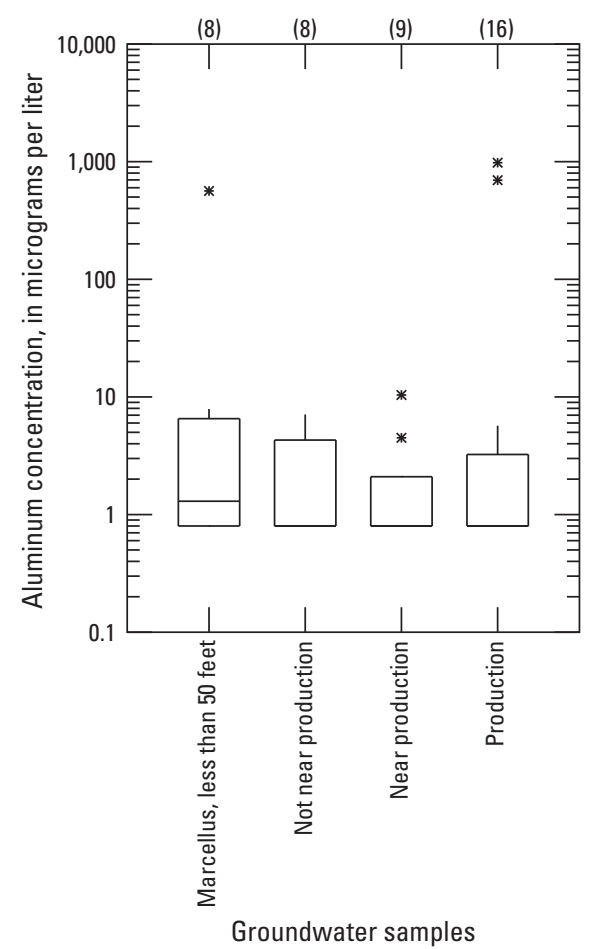

$\boldsymbol{B}$

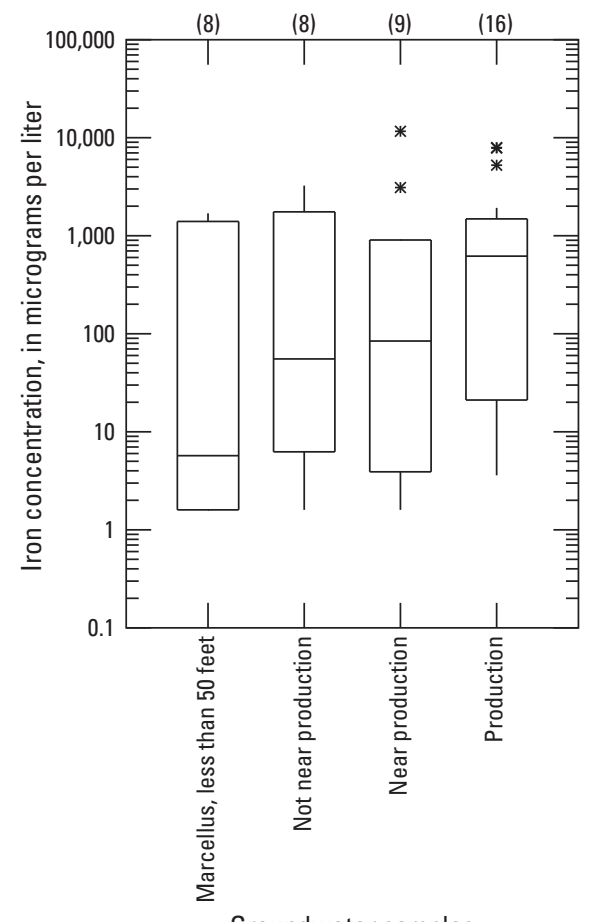

Groundwater samples

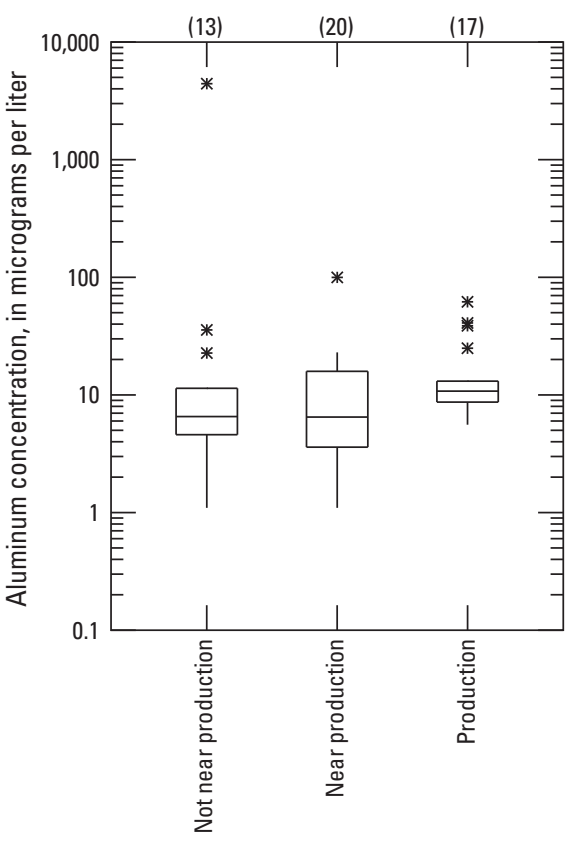

Base-flow samples

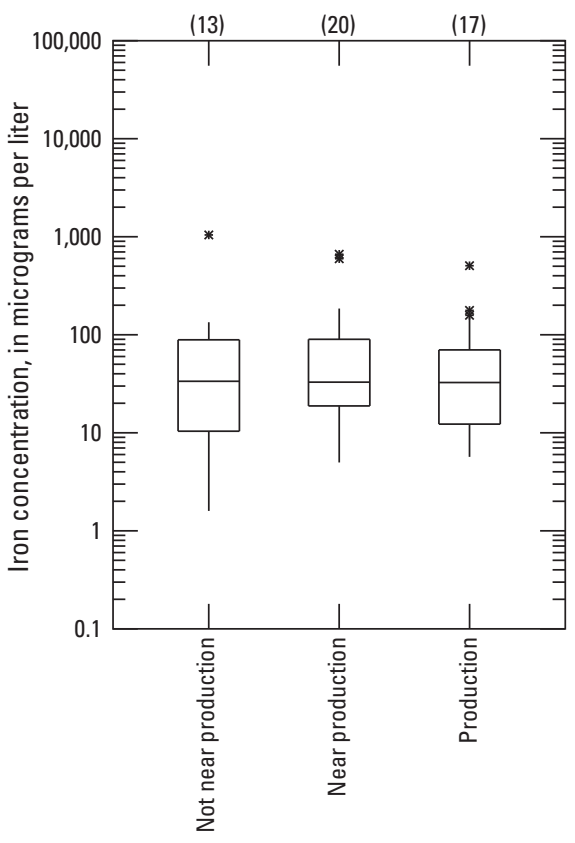

Base-flow samples
EXPLANATION

(8) Number of samples

* Outlier

1.5 times interquartile range

75th percentile

Median (50th percentile)

25th percentile

-1.5 times interquartile range
Figure 16. Distribution of trace-element concentrations in groundwater and base-flow samples collected as part of the baseline study, 2011-12, Monongahela River Basin, West Virginia, grouped by gas production bin: $A$, aluminum, $B$, iron, $C$, manganese, $D$, barium, $E$, strontium, $F$, cobalt, $G$, molybdenum, and $H$, arsenic. 
C

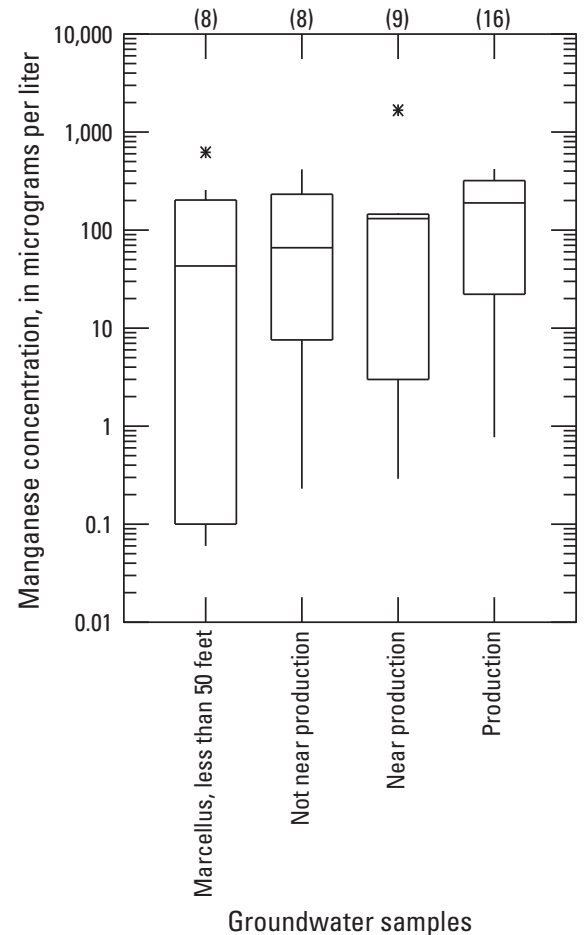

D

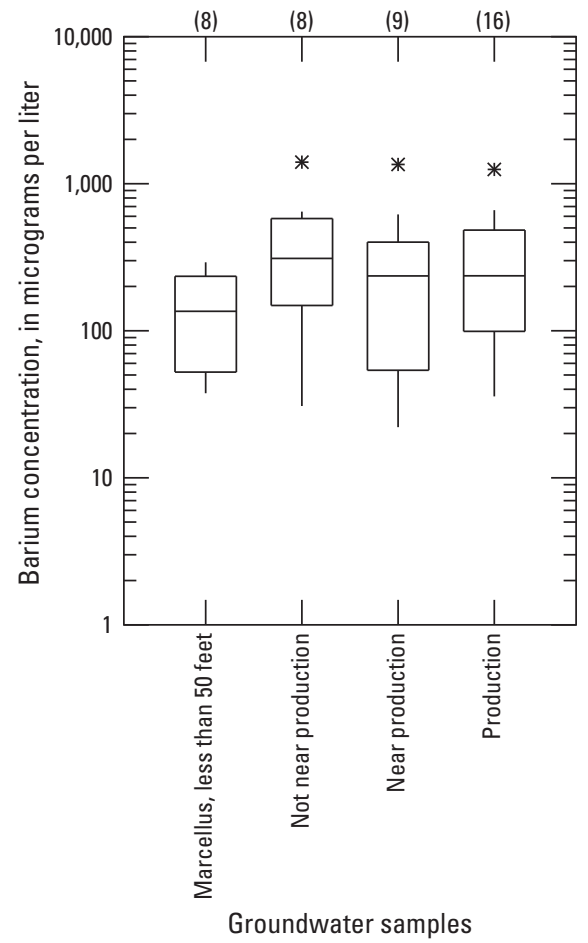

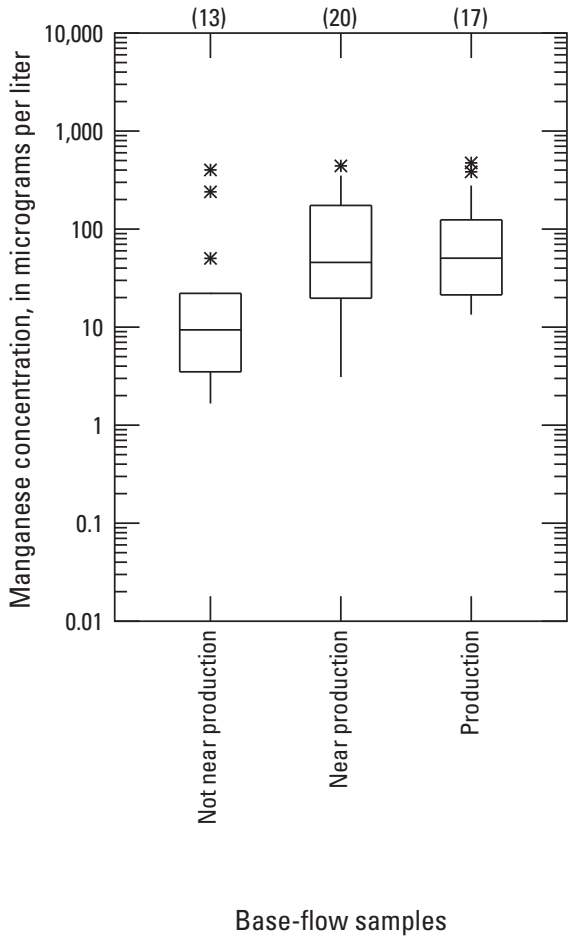

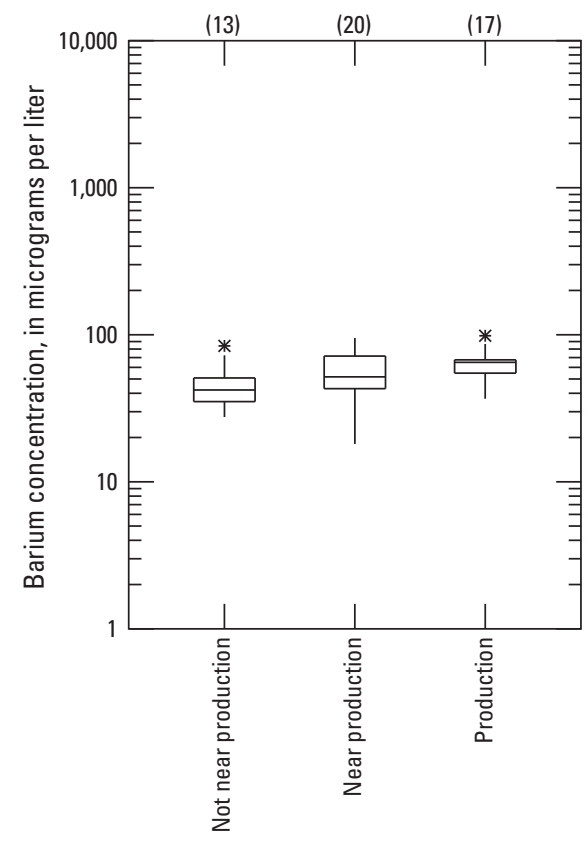

Base-flow samples
EXPLANATION

(8) Number of samples

* Outlier

1.5 times interquartile range

75th percentile

Median (50th percentile)

25th percentile

-1.5 times interquartile range
Figure 16. Distribution of trace-element concentrations in groundwater and base-flow samples collected as part of the baseline study, 2011-12, Monongahela River Basin, West Virginia, grouped by gas production bin: $A$, aluminum, $B$, iron, $C$, manganese, $D$, barium, $E$, strontium, $F$, cobalt, $G$, molybdenum, and $H$, arsenic. -Continued 
$\boldsymbol{E}$

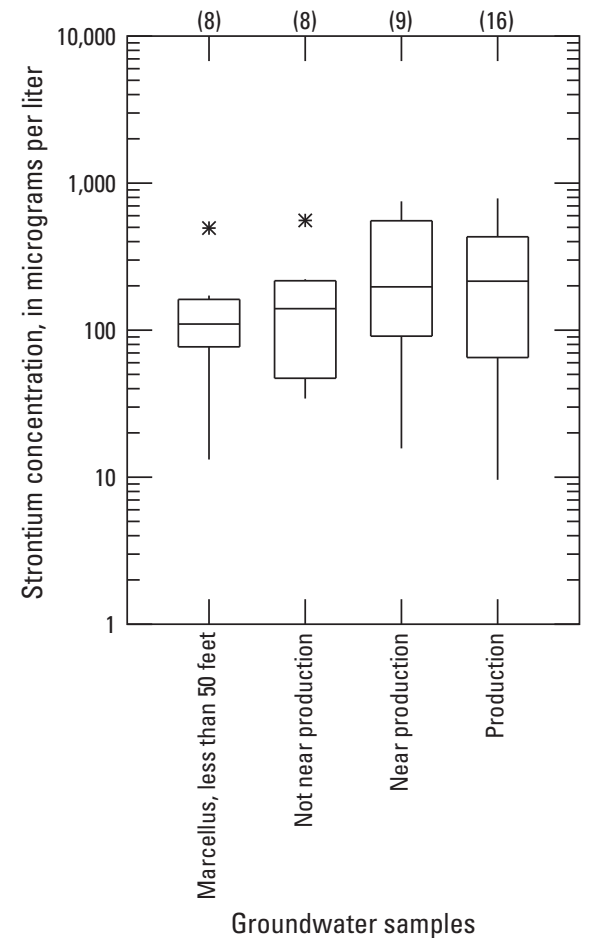

$\boldsymbol{F}$

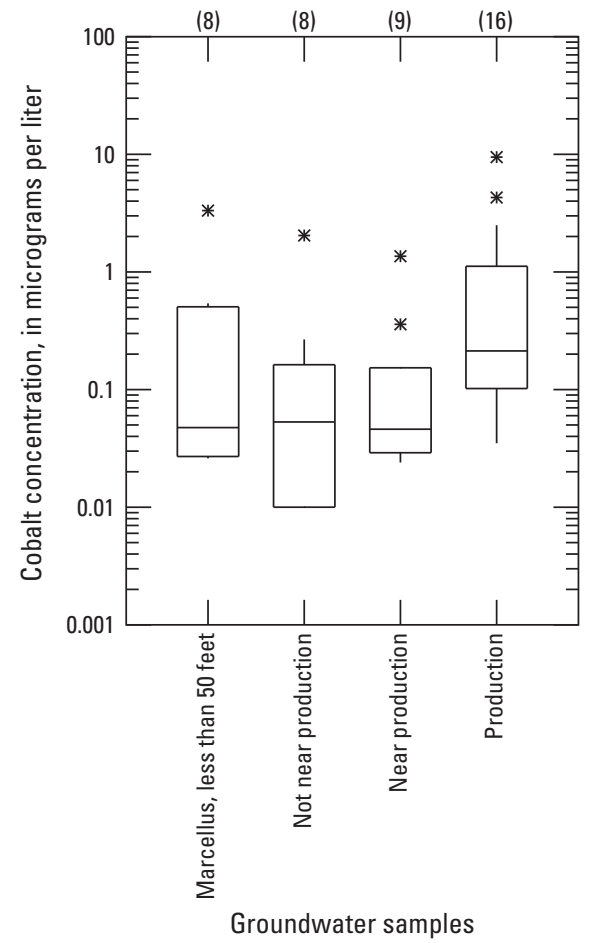

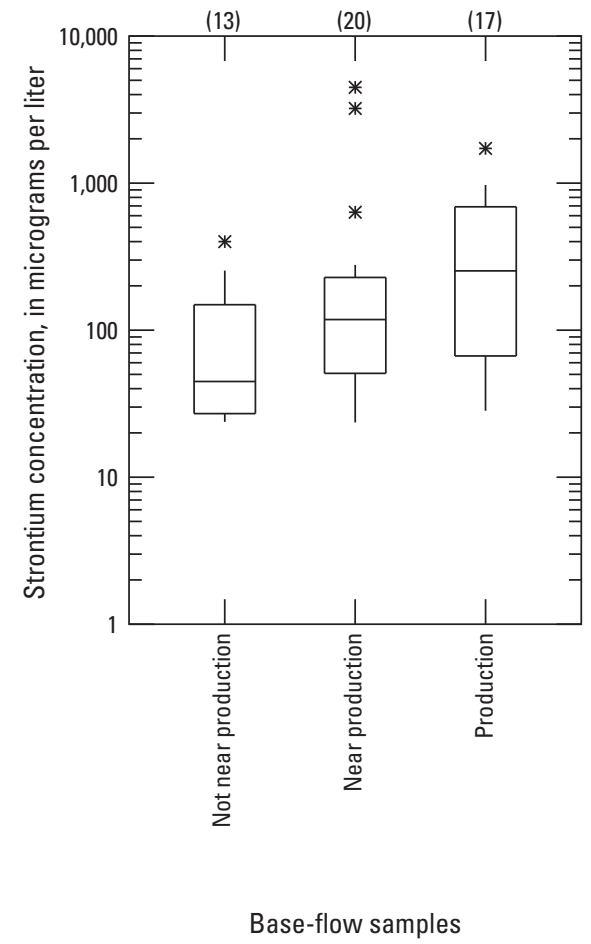

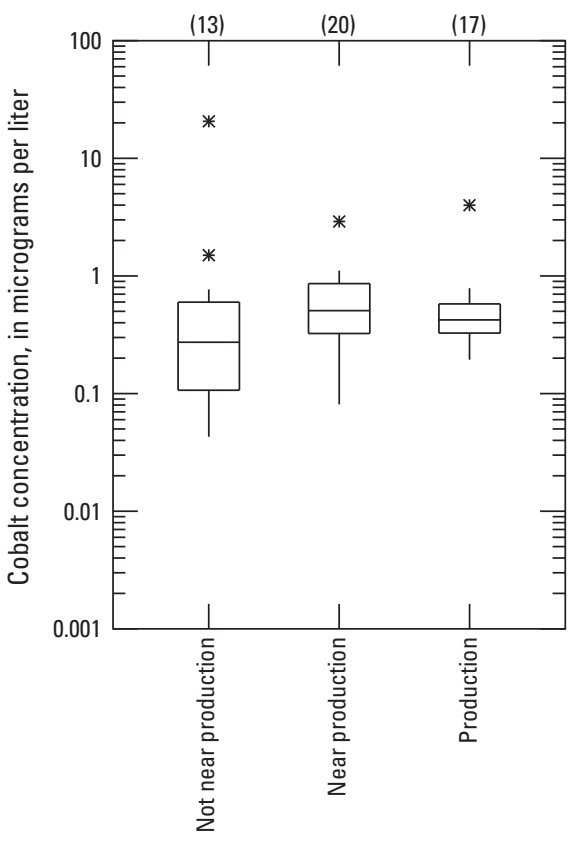

Base-flow samples
EXPLANATION

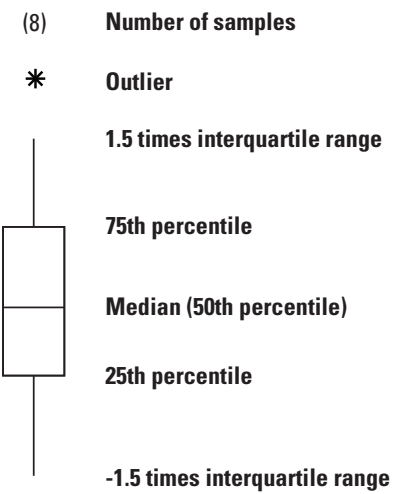

-1.5 times interquartile range
Figure 16. Distribution of trace-element concentrations in groundwater and base-flow samples collected as part of the baseline study, 2011-12, Monongahela River Basin, West Virginia, grouped by gas production bin: $A$, aluminum, $B$, iron, $C$, manganese, $D$, barium, $E$, strontium, $F$, cobalt, $G$, molybdenum, and $H$, arsenic. -Continued 
G

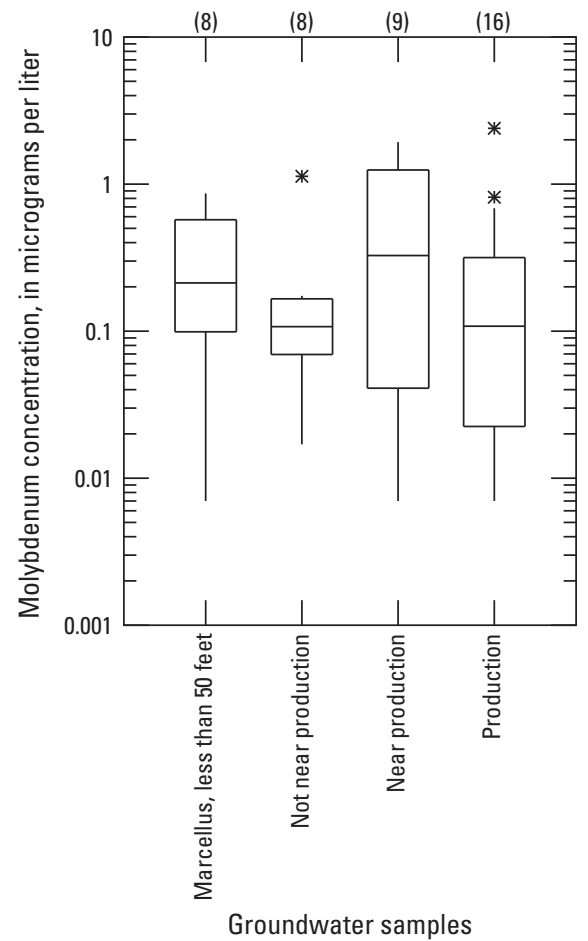

H

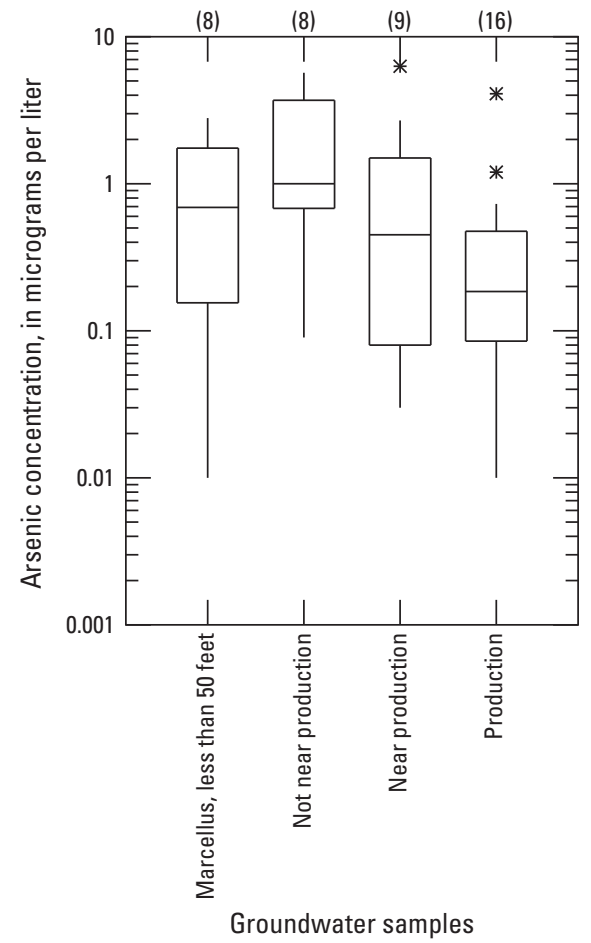

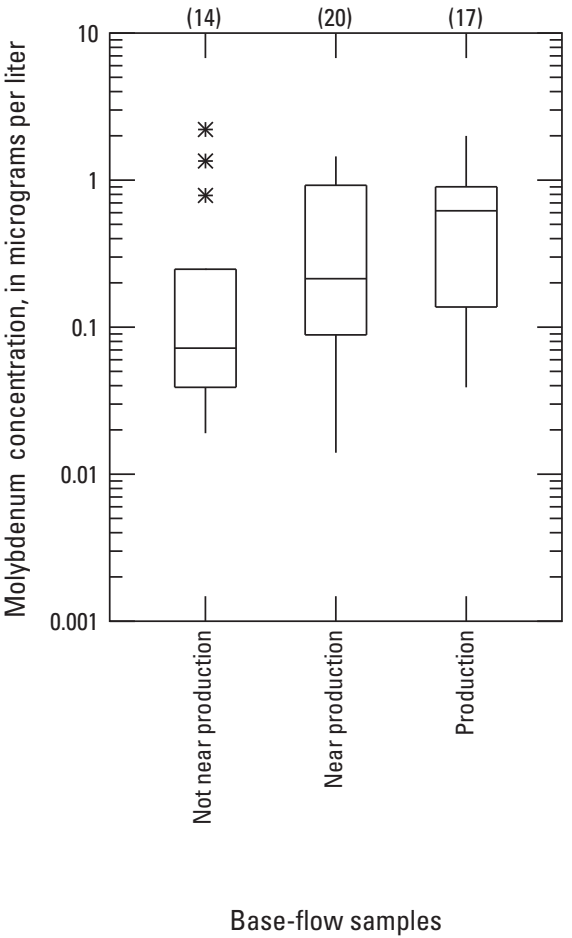

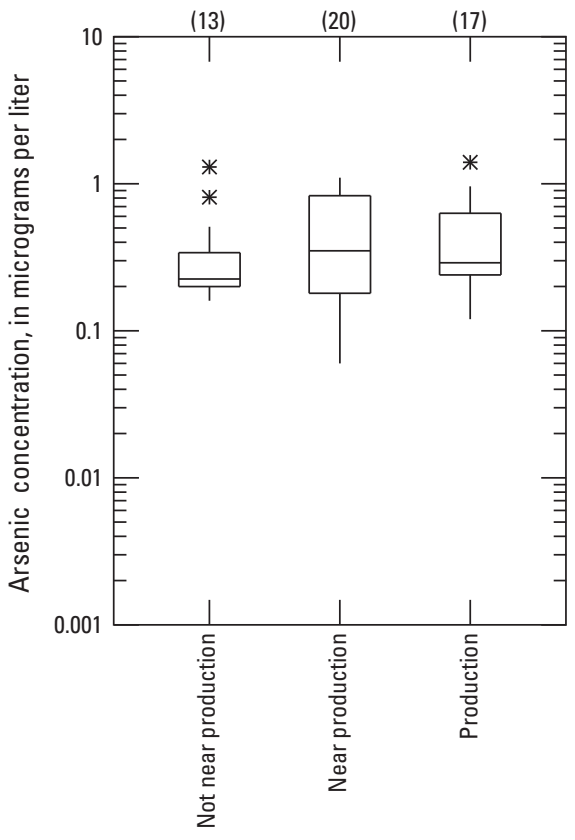

Base-flow samples
EXPLANATION

(8) Number of samples

* Outlier

1.5 times interquartile range

75th percentile

Median (50th percentile)

25th percentile

-1.5 times interquartile range
Figure 16. Distribution of trace-element concentrations in groundwater and base-flow samples collected as part of the baseline study, 2011-12, Monongahela River Basin, West Virginia, grouped by gas production bin: $A$, aluminum, $B$, iron, $C$, manganese, $D$, barium, $E$, strontium, $F$, cobalt, $G$, molybdenum, and $H$, arsenic. 


\section{Naturally Occurring Radioactive Materials}

Numerous sources of naturally occurring radioactive material (NORM), such as uranium and radium, are present in the study area, including sandstone and shale, coal, and the deep formation water associated with oil and gas. Both uranium and thorium, NORMs that radioactively decay to radium isotopes, occur within the deeper shale-gas bearing formations of the Appalachian region (Rowan and others, 2011). Hem (1985) states that the range of uranium concentrations is typically between $0.10 \mu \mathrm{g} / \mathrm{L}$ and $10.0 \mu \mathrm{g} / \mathrm{L}$.

For this study, only the more common NORMs - uranium (U), uranium isotopes (U-234, U-235, U-238), and radium (Ra) isotopes (Ra-224, Ra-226, Ra-228)—were analyzed (table 1). All samples were analyzed for total uranium. If uranium was detected in a sample, that sample was further analyzed for uranium and radium isotopes. Total uranium is composed of several isotopes including U-234, U-235, and $\mathrm{U}-238$. U-238 is the dominant form and is the starting point in a radioactive decay series that ends with lead-206 (Hem, 1985). Radium has four naturally occurring isotopes (Ra223, Ra-224, Ra-226, and Ra-228). Ra-228 and Ra-224 are disintegration products of thorium-232, Ra-223 is a disintegration product of $\mathrm{U}-235$, and $\mathrm{Ra}-226$ is a disintegration product of U-238 (Hem, 1985). Additionally, gross alpha and beta activities were determined for all samples (table 6).

Of the 41 groundwater samples analyzed for uranium, none exceeded the USEPA MCL of $30 \mu \mathrm{g} / \mathrm{L}$ (table 6). Eighteen of 41 samples had concentrations less than the $0.004 \mu \mathrm{g} / \mathrm{L}$ analytical method detection limit, and the median concentration was only $0.007 \mu \mathrm{g} / \mathrm{L}$. Ra-224, Ra-226, and Ra-228 had similar low activities. None of the samples from the 41 wells that were analyzed for Ra-226, or the samples from 14 wells that were analyzed for Ra-228, had concentrations exceeding 5 picocuries per liter (pCi/L), and only 1 site (Pre-0163) had a concentration of combined Ra-228 and Ra-228 (5.1 pCi/L) greater than $5 \mathrm{pCi} / \mathrm{L}$, which is the EPA MCL drinking water standard for combined Ra-226 and Ra-228. Median activities of Ra-226 and Ra-228 were only $0.27 \mathrm{pCi} / \mathrm{L}$ and $0.42 \mathrm{pCi} / \mathrm{L}$, respectively (table 6). Of the 41 wells sampled, only 5 wellsPre-0163, Pre-0162, Lew-0221, Tay-0130, and Pre-0172had either a single value or combined value of Ra-226 or $\mathrm{Ra}-228$ exceeding $1.0 \mathrm{pCi} / \mathrm{L}$. The source of radium in these outlier wells is unknown.

Table 6. Statistical summary of naturally occurring radioactive materials in groundwater and base-flow samples collected as part of the Marcellus Shale baseline survey, Monongahela River Basin, West Virginia, 2011-12.

[ $\mu \mathrm{g} / \mathrm{L}$, micrograms per liter; <, less than; U, uranium; Ra, radium; Th, thorium; $\mathrm{pCi} / \mathrm{L}$, picoCuries per liter; wf, filtered water sample, SSLC, sample-specific laboratory criteria; MCL, maximum contaminant level (U.S. Environmental Protection Agency, 2009); NA, not applicable]

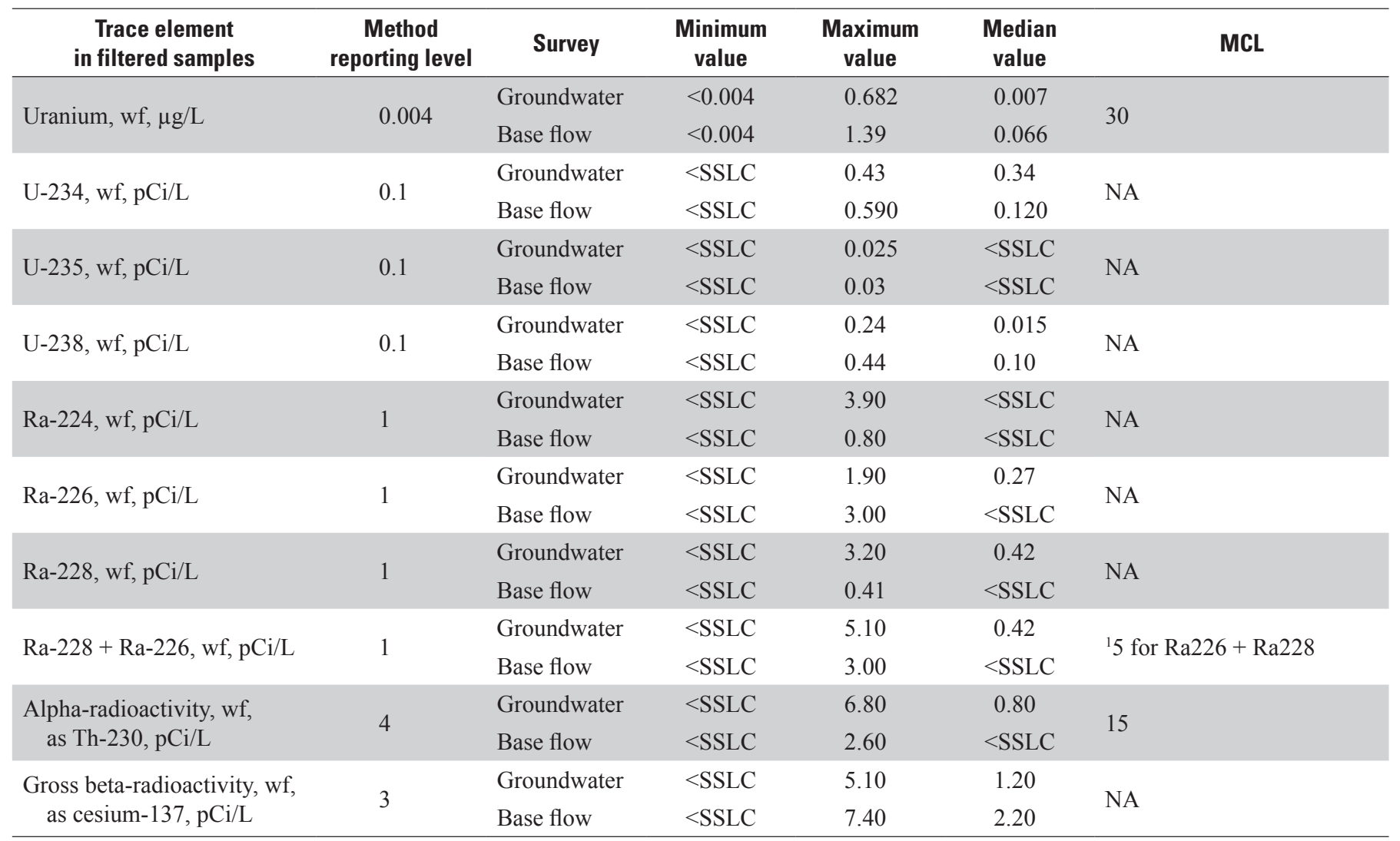

${ }^{1}$ One sample exceeded the $5 \mathrm{pCi} / \mathrm{L}$ MCL for Ra-226 plus Ra-228, Pre-0163 with an activity of $5.1 \mathrm{pCi} / \mathrm{L}$. 
Uranium was detected in 47 of the 50 base-flow survey samples. Concentrations in four samples were less than the laboratory reporting of $0.004 \mu \mathrm{g} / \mathrm{L}$. The highest uranium concentration was $1.39 \mu \mathrm{g} / \mathrm{L}$, and the median concentration was $0.066 \mu \mathrm{g} / \mathrm{L}$ (table 6 ). Uranium concentrations did not vary significantly among the gas-production bins (Kruskal-Wallis test, $p=0.0678$ ) (fig. 17). The 47 samples with quantifiable concentrations of uranium were analyzed for uranium isotopes U-234, U-235 and U-238. Uranium-238 was found in the greatest number of samples, 31 , with a maximum activity of $0.44 \mathrm{pCi} / \mathrm{L}$.

Radium-226, the most common radium isotope, was found in only 13 of the 50 base-flow survey samples. The highest activity was $3.0 \mathrm{pCi} / \mathrm{L}$ (table 6 ) in the sample from Elk Creek near Romines Mills, W.Va. No base-flow survey sample exceeded the EPA MCL of $5.0 \mathrm{pCi} / \mathrm{L}$. The other radium isotopes analyzed for, radium 224 and radium 228 , were detected in 7 and 2 samples, respectively.

\section{Isotopes}

Isotopic data sampling and analytical methods are discussed in detail by Mulder (2012) and Pelak (2014). The studies by Mulder (2012) and Pelak (2014) included analysis for $\delta^{18} \mathrm{O}_{\mathrm{H} 2 \mathrm{O}}, \delta^{2} \mathrm{H}_{\mathrm{H} 2 \mathrm{O}}, \delta^{13} \mathrm{C}_{\mathrm{DIC}}, \delta^{34} \mathrm{~S}_{\mathrm{SO} 4}, \delta^{18} \mathrm{O}_{\mathrm{SO} 4}, \delta^{2} \mathrm{H}_{\mathrm{CH} 4}$, and $\delta^{13} \mathrm{C}_{\mathrm{CH} 4}$
These studies also present analysis of the isotopic and supporting major ion data, and interpretation of processes and major findings based on the isotopic analysis.

Numerous studies have been done to analyze national and global trends in oxygen-18 $\left(\delta^{18} \mathrm{O}\right)$ and hydrogen $\left(\delta^{2} \mathrm{H}\right)$ in precipitation and rivers. Kendall and Coplen (2001) correlated areas across the United States using $\delta^{18} \mathrm{O}_{\mathrm{H} 2 \mathrm{O}}, \delta^{2} \mathrm{H}_{\mathrm{H} 2 \mathrm{O}}$, deuterium excess ( $d$-excess), and the corresponding Global Meteoric Water Line (GMWL) slope. Groundwater results for the study area fall within the range of the central east coast data for all mentioned constituents. Topography, latitude, and temperature are shown to affect the composition of $\delta^{18} \mathrm{O}_{\mathrm{H} 2 \mathrm{O}}$ on the east coast and, therefore, the study area.

The composition of hydrogen and oxygen isotopes in groundwater samples shows signatures similar to those of precipitation and river water in the study area, which are more depleted on the east coast than on the west coast. The isotopic signatures in the groundwater samples also have corresponding higher $\mathrm{d}$-excess values. These higher $\mathrm{d}$-excess values are the result of the study area being downwind of air masses originating in the Great Lakes area. The original air masses are subjected to high rates of evaporation over the water bodies, and the evaporative vapor is mixed with atmospheric waters. In conjunction with local processes, such as altitude and latitude, the isotopic signatures of $\delta^{18} \mathrm{O}_{\mathrm{H} 2 \mathrm{O}}$ and $\delta^{2} \mathrm{H}_{\mathrm{H} 2 \mathrm{O}}$ plot above the GMWL in the area of an arid vapor mass.
$\boldsymbol{A}$

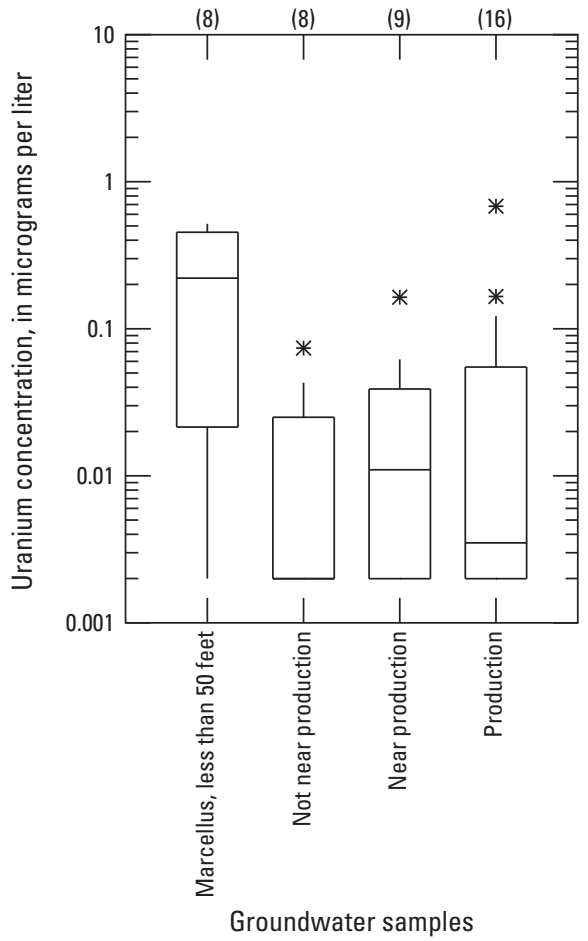

\section{B}

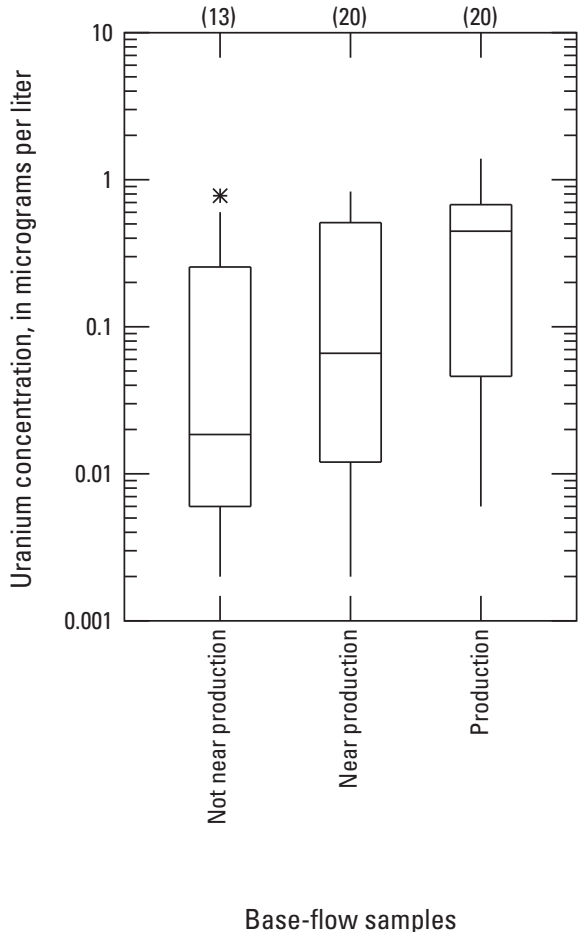

EXPLANATION

Number of samples

* Outlier

1.5 times interquartile range

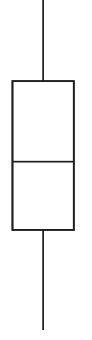

75th percentile

Median (50th percentile)

25th percentile

-1.5 times interquartile range

Figure 17. Distribution of uranium concentrations in groundwater and base-flow samples collected as part of the Marcellus Shale baseline study, Monongahela River Basin, West Virginia, 2011-12, grouped by gas production bin: $A$, groundwater samples and $B$, base-flow samples. 


\section{Groundwater Survey}

The overall signatures of the study area groundwater demonstrate a combination of local effects with processes moving downwind from the Great Lakes, affecting precipitation and, therefore, groundwater recharge. The processes may involve elevation, topography, temperature, and humidity levels. The cluster of oxygen and hydrogen isotopic data points along the GMWL indicate steady vapor mass sources (fig. 18). The position of data points on the GMWL indicates a deceivingly arid source but is the result of a mixed vapor mass of evaporative and atmospheric moisture originating from the Great Lakes.

Isotope analyses were done for dissolved methane in 11 of the 41 groundwater samples. The isotopic signatures of methane $\left(\delta^{2} \mathrm{H}_{\mathrm{CH} 4}\right.$ and $\left.\delta^{13} \mathrm{C}_{\mathrm{CH} 4}\right)$ in groundwater can be plotted to evaluate several possible sources of methane, including thermogenic, biogenic, or mixed sources (fig. 19A-C). Dominantly deep microbial stimulated methane with mixing is shown in Coleman (1994). Methane originating from biogenic and thermogenic sources and a mix of the two is shown in Whiticar (1999), and a dominantly thermogenic source is shown in Molofsky and others (2011). Methane in all groundwater samples falls within a cluster distinct from that of the Marcellus Shale gas collected from Greene County, Pa., and distinct from gases collected from Ordovician-, Silurian- and Devonian-age formations in West Virginia and Pennsylvania (Sharma and others, 2013a; 2014a; 2014b). The isotopic signatures of methane in the 11 samples from this study are generally similar to the isotopic signatures of coal-bed methane-a mixture of methane from both biogenic and thermogenic processes, or a mixture of methane from all three sources, biogenic, thermogenic and coal-bed methane.

\section{Base-Flow Survey}

No major deviations from the GMWL were observed for base-flow samples, indicating that meteoric water and shallow groundwater are major components in these streams. Water samples collected from streams at highest elevations, 1,335 to 2,854 feet above MSL, on the eastern and southern edges of the study area had the most depleted values of $\delta^{18} \mathrm{O}_{\mathrm{H} 2 \mathrm{O}}$ and $\delta^{2} \mathrm{H}_{\mathrm{H} 2 \mathrm{O}}$ owing to the elevation effect (Dansgaard, 1964, Pelak and Sharma, 2014). None of the base-flow samples had enriched $\delta^{18} \mathrm{O}_{\mathrm{H} 2 \mathrm{O}}$ and $\delta^{2} \mathrm{H}_{\mathrm{H} 2 \mathrm{O}}$ composition, which is seen in backflow waters associated with Marcellus Shale development (Dresel and Rose, 2010; Warner and others, 2012; Sharma and others, 2014a). In addition, none of the base-flow samples show preferential enrichment of $\delta^{18} \mathrm{O}_{\mathrm{H} 2 \mathrm{O}}$ over $\delta^{2} \mathrm{H}_{\mathrm{H} 2 \mathrm{O}}$, leading to a more horizontal shift to the right of the GMWL, as seen in the brines of the area (Warner and others, 2012; Sharma and others, 2014a; Pelak and Sharma, 2014). Variations in $\delta^{18} \mathrm{O}_{\text {н2О }}$ and $\delta^{2} \mathrm{H}_{\mathrm{H} 2 \mathrm{O}}$ are likely due to local differences in soil water, groundwater recharge, and elevation effects.
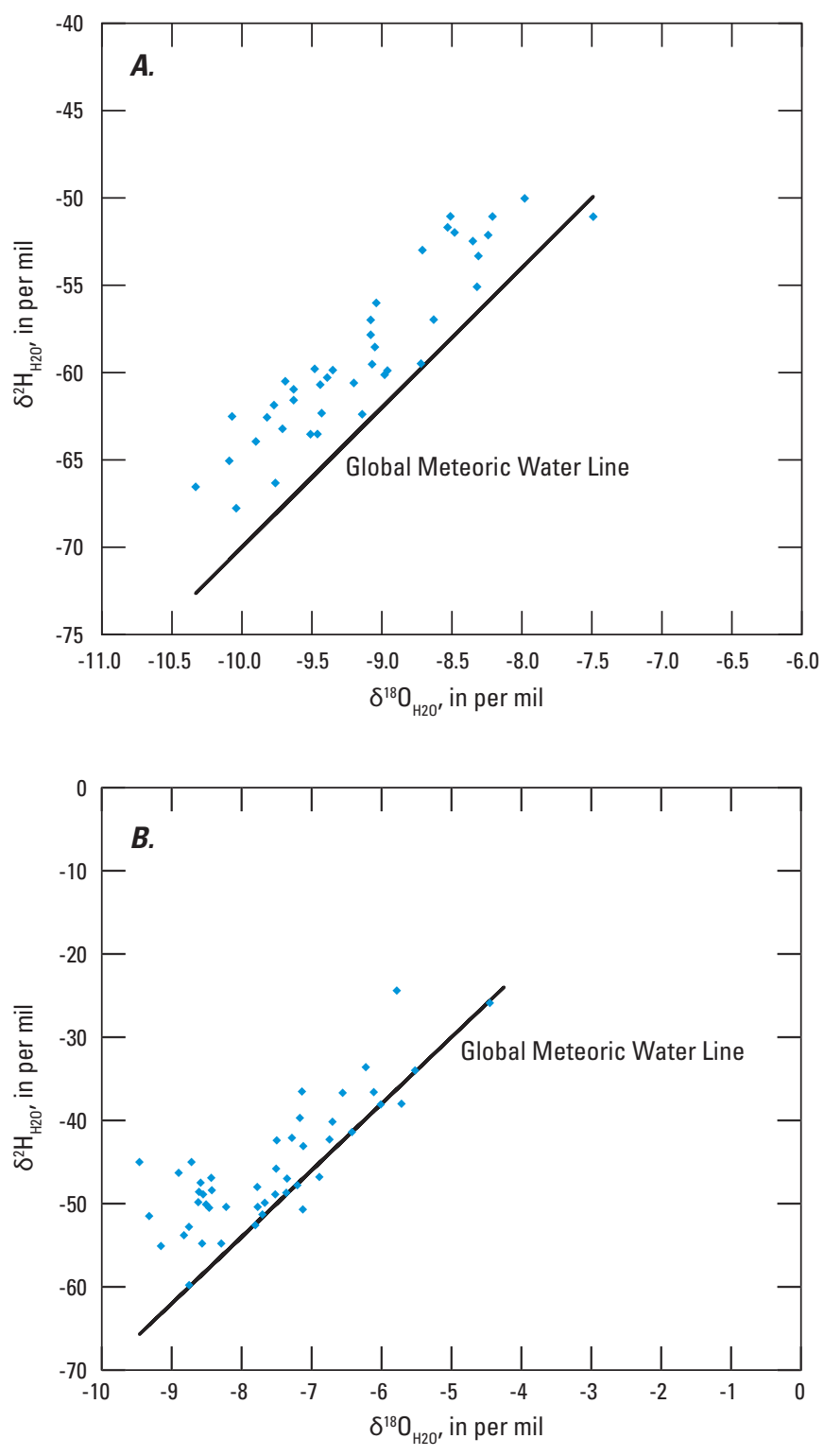

Figure 18. Oxygen and hydrogen isotopic composition of water in $A$, groundwater samples and $B$, base-flow samples collected as part of the Marcellus Shale baseline study in the Monongahela River Basin, West Virginia, 2011-12, and the Global Meteoric Water Line (Global Meteoric Water Line from Craig, 1961).

The main sources of dissolved inorganic carbon (DIC) in surface waters are the decay of organic matter, carbonate dissolution, and diffusion of atmospheric $\mathrm{CO}_{2}$. The relative contribution of carbon from different end members and carbon speciation ultimately controls the overall $\delta^{13} \mathrm{C}_{\mathrm{DIC}}$ composition of the water. The range of $\delta^{13} \mathrm{C}_{\mathrm{DIC}}$ in most natural waters receiving almost equal contributions from decaying organic matter and soil carbonate dissolution is from -16 to -11 per mil (\%) Vienna Peedee belemnite (VPDB; Clark and Fritz, 1997). The $\delta^{13} C_{\text {DIC }}$ in most of the base-flow survey samples 

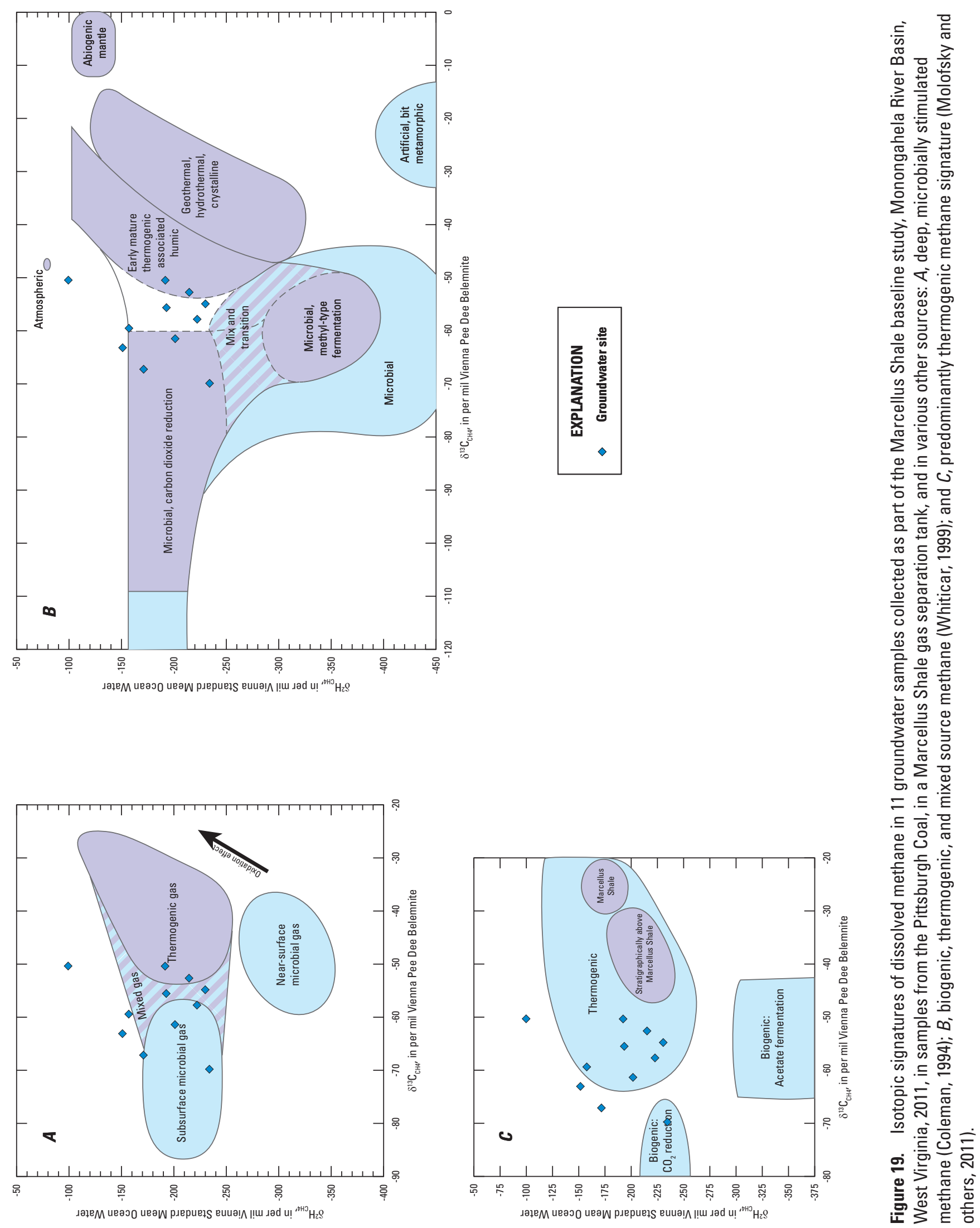

造

号

은

$\geq>$

可

要

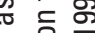

恶

离.

is

$\frac{0}{\pi}$

क

焉

离

二 $\Xi$

$\subseteq \bar{\pi}$ व

¿

일

垔

要

号

은

क ⿻

否离

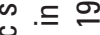

홍

的芯完

\%

言范跑恋 
ranged from -14.57 to $-5.87 \%$ VPDB, but two samples had $\delta^{13} \mathrm{C}_{\mathrm{DIC}}$ values of $-24.61 \%$ and $-24.05 \%$ VPDB (fig. 19).

These two samples were collected from the High Production and Near Low Production bins in study area. In a recent study, the $\delta^{13} \mathrm{C}_{\mathrm{DIC}}$ values of backflow water collected from Marcellus Shale wells was found to be highly enriched with an average value $+21 \%$ VPDB owing to late stage biogenic methanogenesis (Sharma and others, 2013b). However, no water samples had positive $\delta^{13} \mathrm{C}_{\mathrm{DIC}}$ signatures similar to that of backflow water from Marcellus Shale operations. The two samples with low $\delta^{13} \mathrm{C}_{\text {DIC }}$ values $(\sim-24 \%)$ are most likely receiving carbon from oxidation of isotopically depleted sources, such as soil organic matter decay or coals/shales in the region, which are known to have a range of -25.4 to $-21.6 \%$ VPDB (Sharma and others, $2013 \mathrm{~b}$ ). Out of the remaining samples, 58 percent have $\delta^{13} \mathrm{C}_{\text {DIC }}$ values greater than $-11 \%$, indicating a contribution from dissolution of isotopically enriched carbonate rocks (fig. 20).

Oxidation of pyritic sulfides in coal beds can result in the production of sulfuric acid $\left(\mathrm{H}_{2} \mathrm{SO}_{4}\right)$, which can result in enhanced dissolution of isotopically enriched carbonate (Sharma and others, 2013b). In addition, degassing of isotopically depleted $\mathrm{CO}_{2}$ species from total DIC in standing or slow moving streams or invasion of isotopically enriched atmospheric $\mathrm{CO}_{2}$ in waters with low partial pressures of $\mathrm{CO}_{2}$ can also result in slight enrichment of $\delta^{13} \mathrm{C}_{\mathrm{DIC}}$ in waters (Atekwana and Krishnamurthy, 1998; Doctor and others, 2008; Sharma and others, 2013b). This indicates that some of the enriched $\delta^{13} \mathrm{C}_{\mathrm{DIC}}$ signatures seen in streams could be the result of a contribution from mine discharges or atmospheric exchange, especially in slow moving streams.

The stable isotopes of $\delta^{34} \mathrm{~S}_{\mathrm{SO} 4}$ and $\delta^{18} \mathrm{O}_{\mathrm{SO} 4}$ have been used to distinguish sources of dissolved sulfate in streams and the processes controlling the overall sulfate concentration. The stable isotopes for the base-flow samples were $\delta^{34} \mathrm{~S}_{\mathrm{SO}}$, ranging from -7.60 to $+13.40 \%$ Vienna Canyon Diablo Troilite (VCDT) and $\delta^{18} \mathrm{O}_{\mathrm{SO} 4}$, ranging from- $6.4 \%$ to $+10.6 \%$.

No pattern was observed among concentrations of $\delta^{18} \mathrm{O}_{\text {SO4 }}$ and $\delta^{34} \mathrm{~S}_{\mathrm{sO} 4}$ and Marcellus Shale gas-production bins. It is assumed that the primary source of dissolved sulfate in the samples for this study is from the oxidation of pyritic minerals (Cravotta, 2008a). The large variation in values of $\delta^{34} \mathrm{~S}_{\mathrm{SO} 4}$ in this study could be due to the wide range in values for pyrite minerals found in many strata in the study area (Mulder, 2012). There is little to no fractionation of sulfur during

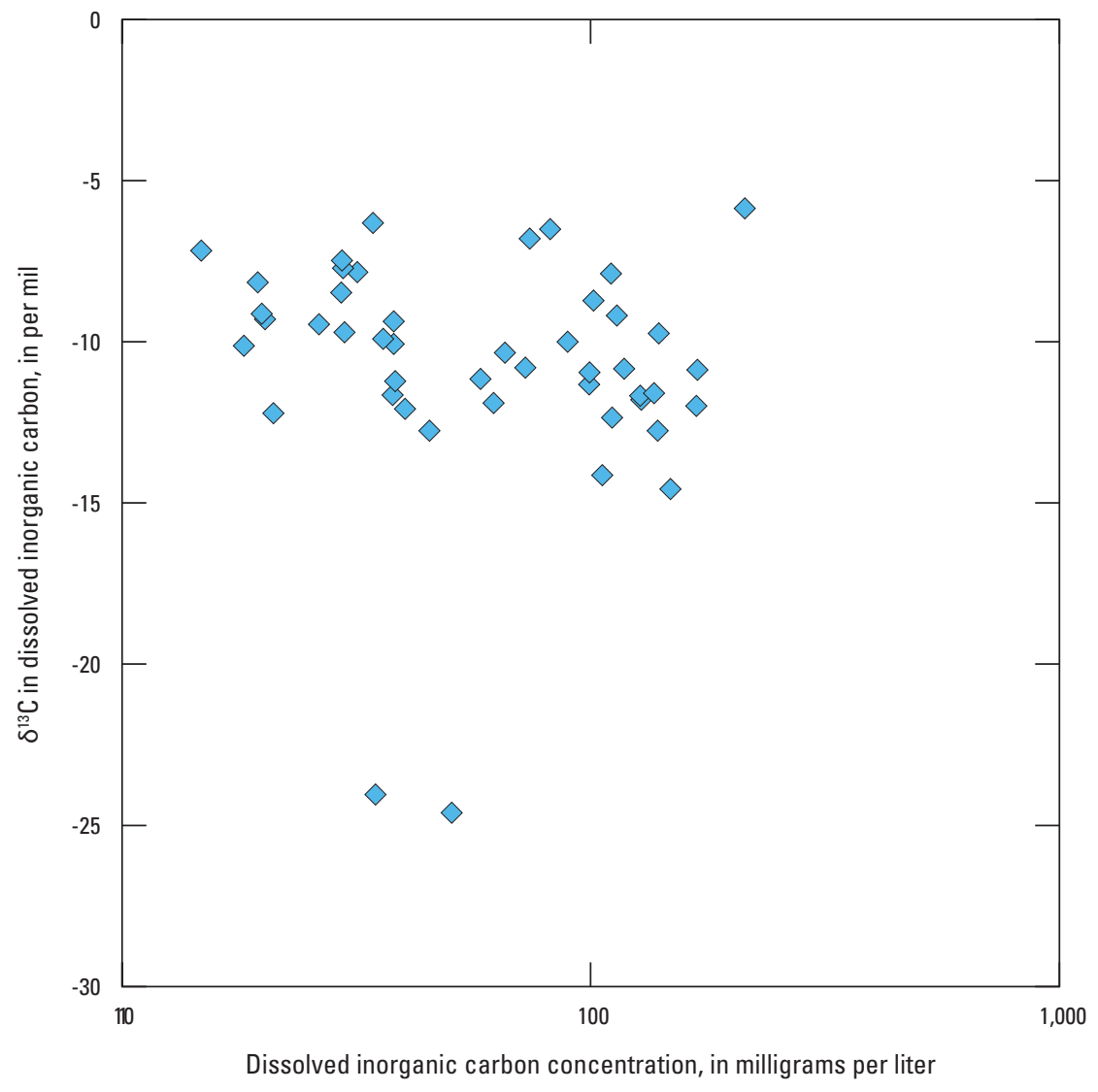

Figure 20. Isotopic composition of dissolved inorganic carbon in base-flow samples collected as part of the Marcellus Shale baseline study, Monongahela River Basin, West Virginia, 2012. 
the oxidation of sulfide, meaning $\delta^{34} \mathrm{~S}_{\mathrm{SO} 4}$ values will remain virtually the same as that in the material they were derived from. The $\delta^{34} \mathrm{~S}_{\mathrm{SO} 4}$ value of pyrite in general has a wide range, from -25 to $0 \%$ VCDT (Clark and Fritz, 1997). A recent study (Sharma and others, 2013b) found that coals and shales of the Pittsburgh coal bed had $\delta^{34} \mathrm{~S}_{\mathrm{SO} 4}$ values ranging from $+0.6 \%$ to $+2.4 \%$ VCDT. Reducing conditions for the surface waters in this study would be limited to stagnant pools with an organic substrate, wetland areas, and similar situations; the bacterial sulfate reduction of pyrite in surface water is limited. However, bacterial sulfate reduction occurring in anaerobic waters, such as water from coal mines, causes $\delta^{34} \mathrm{~S}_{\mathrm{SO} 4}$ and $\delta^{18} \mathrm{O}_{\mathrm{sO} 4}$ enrichment as a result of the preferential use of the lighter ${ }^{32} \mathrm{~S}$ isotope by sulfate-reducing bacteria. Contributions to streamflow from flooded underground mines or abandoned surface mines are common and widespread in the study area (McColloch and others, 2012). Reducing conditions are possible in mine pools, and bacterial reduction of sulfate in these pools confounds the interpretation of the isotopic composition of sulfate. Because the samples show $\delta^{34} \mathrm{~S}_{\mathrm{SO} 4}$ values ranging from -7.60 to $+13.40 \%$ VCDT, it is not clear whether samples with enriched values of $\delta^{34} \mathrm{~S}_{\mathrm{SO} 4}$ are due to streams receiving input from dissolved sulfate that has been bacterially reduced or whether the pyrite from which the sulfate is derived has enriched values ( $>0 \%$ ) for $\delta^{34} \mathrm{~S}_{\mathrm{sO} 4}$

Stable isotope values of $\delta^{18} \mathrm{O}_{\mathrm{SO} 4}$ also show a wide range of values for the base-flow samples. The source of oxygen in dissolved sulfate is derived from the oxygen in water and from atmospheric $\mathrm{O} 2$ (Gu and others, 2008; Toran and Harris, 1989). The value of $\delta^{18} \mathrm{O}_{\mathrm{s} O 4}$ depends largely upon the environment in which the sulfide oxidation occurred. For base-flow samples, 85 percent had $\delta^{18} \mathrm{O}_{\mathrm{SO} 4}$ values greater than $0 \%$, indicating that these samples are receiving ${ }^{18} \mathrm{O}$ from atmospheric $\mathrm{O}_{2}$, which has a more enriched value $(+23.5 \%$; Kroopnick and Craig, 1972) relative to surface waters in the study area. Because of the large range in $\delta^{34} \mathrm{~S}_{\mathrm{SO} 4}$ and $\delta^{18} \mathrm{O}_{\mathrm{SO} 4}$ values in the samples, multiple processes, such as sulfate reduction, atmospheric input, and a wide range of sulfur isotope values for pyrite, are likely to affect the isotopic composition of sulfate.

\section{Dissolved Gases}

Gases, either atmospheric or derived from biogeochemical processes in aquifers, can provide information to better understand the source of recharge to the groundwater system. Nitrogen, oxygen, argon, and carbon dioxide, the primary gases in the atmosphere, are present at concentrations of approximately 78.1 percent $\left(\mathrm{N}_{2}\right), 20.9$ percent $\left(\mathrm{O}_{2}\right), 0.93$ percent (Ar), and 0.03 percent $\left(\mathrm{CO}_{2}\right)$, respectively (Hem, 1985). Atmospheric gases are absorbed by precipitation; the partial pressures of the gases are in proportion to barometric pressure (Busenberg and others, 2001). When precipitation falls on the surface of the earth, some of the water seeps into soil and rock, recharging the groundwater system. As the water percolates through the soil and rock, soil gases become entrained and eventually are dissolved in the recharge water. The addition of soil gases to recharge water can result in the presence of dissolved gases in proportions greater than that in the atmosphere, referred to as excess air (Busenberg and others, 2001).

Methane, another gas found in the groundwaters of the study area, is present in the atmosphere but at low concentrations $(0.00015 \%$; Hem, 1985). Methane in groundwater is primarily due to methanogenesis, the breakdown of organic compounds, in either shallow biogenic environments, such as wetlands and landfills, or deeper thermogenic environments, such as oil and gas reservoirs. Methanogenesis in groundwater is indicative of reducing environments within the aquifer. Coal-bed methane (CBM) is another source of methane in groundwater, but it is not well understood whether CBM in the study area is derived from biogenic or thermogenic methanogenesis (Mulder, 2012).

In addition, because dissolved gas concentrations in the atmosphere are dependent on barometric pressure, the sum of all gases in the atmosphere is equal to the barometric pressure (Busenberg and others, 2001). The partial pressure of gases decreases as elevation increases and increases as elevation decreases. In addition, the temperature of water recharging an aquifer can be calculated from the concentrations of $\mathrm{N}_{2}$, $\mathrm{Ar}$, and other noble gases, based on the principles of Henry's Law, assuming that gases in the recharging water were in equilibrium with the atmosphere at the temperature at which recharge became isolated from the atmosphere (Busenberg and others, 2001). The analyses of dissolved gases in groundwater samples can provide significant insight into the origin of water recharging an aquifer.

For this study, samples were collected from 39 wells and 2 springs in the study area and analyzed for dissolved gas concentrations of nitrogen $\left(\mathrm{N}_{2}\right)$, argon ( $\mathrm{Ar}$ ), oxygen $\left(\mathrm{O}_{2}\right)$, carbon dioxide $\left(\mathrm{CO}_{2}\right)$, and methane $\left(\mathrm{CH}_{4}\right)$, which are summarized in table 7. The concentration of Ar in relation to the concentration of $\mathrm{N}_{2}$ is shown in figure 21, which also shows estimates of excess air content and recharge temperature, based on normalized sea-level concentrations. Samples clustering along the water in equilibrium with air (WEA) line are indicative of shallow groundwater with dissolved gas concentrations similar to that of the atmosphere. In the dissolved gas plot, samples cluster in three distinct groups (A-B-C in fig. 21) with the exception of the sample from well UPS-0178 (D in fig. 21), which had no close affinity to any of the groups.

The dissolved-gas concentration signatures in most of the samples, 38 of 41, indicate a shallow groundwater source. These 38 samples cluster in two groups of 33 and 5 samples. The larger of the two clusters (group $\mathrm{C}$ in fig. 21) had excess air components between $0 \mathrm{~mL}$ and $5 \mathrm{~mL}$ and estimated recharge temperatures between 5 degrees Celsius $\left({ }^{\circ} \mathrm{C}\right)$ and $15^{\circ} \mathrm{C}$, dissolved gas profiles similar to those of typical shallow groundwater found in domestic wells within the study area (McCoy and Kozar, 2007). The estimated recharge temperatures point towards recharge occurring during colder months of the year. The cluster of five samples (group B, fig. 21) had 
Table 7. Statistical summary of dissolved gases in groundwater samples collected as part of the Marcellus Shale baseline survey, Monongahela River Basin, West Virginia, 2011.

[mg/L, milligrams per liter; <, less than]

\begin{tabular}{lcccc}
\hline \multicolumn{1}{c}{$\begin{array}{c}\text { Trace element } \\
\text { in filtered samples }\end{array}$} & $\begin{array}{c}\text { Method } \\
\text { reporting level }\end{array}$ & $\begin{array}{c}\text { Minimum } \\
\text { concentration }\end{array}$ & $\begin{array}{c}\text { Maximum } \\
\text { concentration }\end{array}$ & $\begin{array}{c}\text { Median } \\
\text { concentration }\end{array}$ \\
\hline Nitrogen, $\mathrm{N}_{2}$, dissolved, mg/L & 0.001 & 9.6 & 27.2 & 18.8 \\
Oxygen, $\mathrm{O}_{2}$, dissolved, mg/L & 0.002 & 0.104 & 8.19 & 0.252 \\
Argon, dissolved, mg/L & 0.003 & 0.419 & 0.804 & 0.676 \\
Carbon dioxide, dissolved, mg/L & 0.04 & 0.33 & 68.8 & 18.5 \\
Methane, dissolved, mg/L & 0.001 & $<0.001$ & 48.2 & 0.04 \\
\hline
\end{tabular}

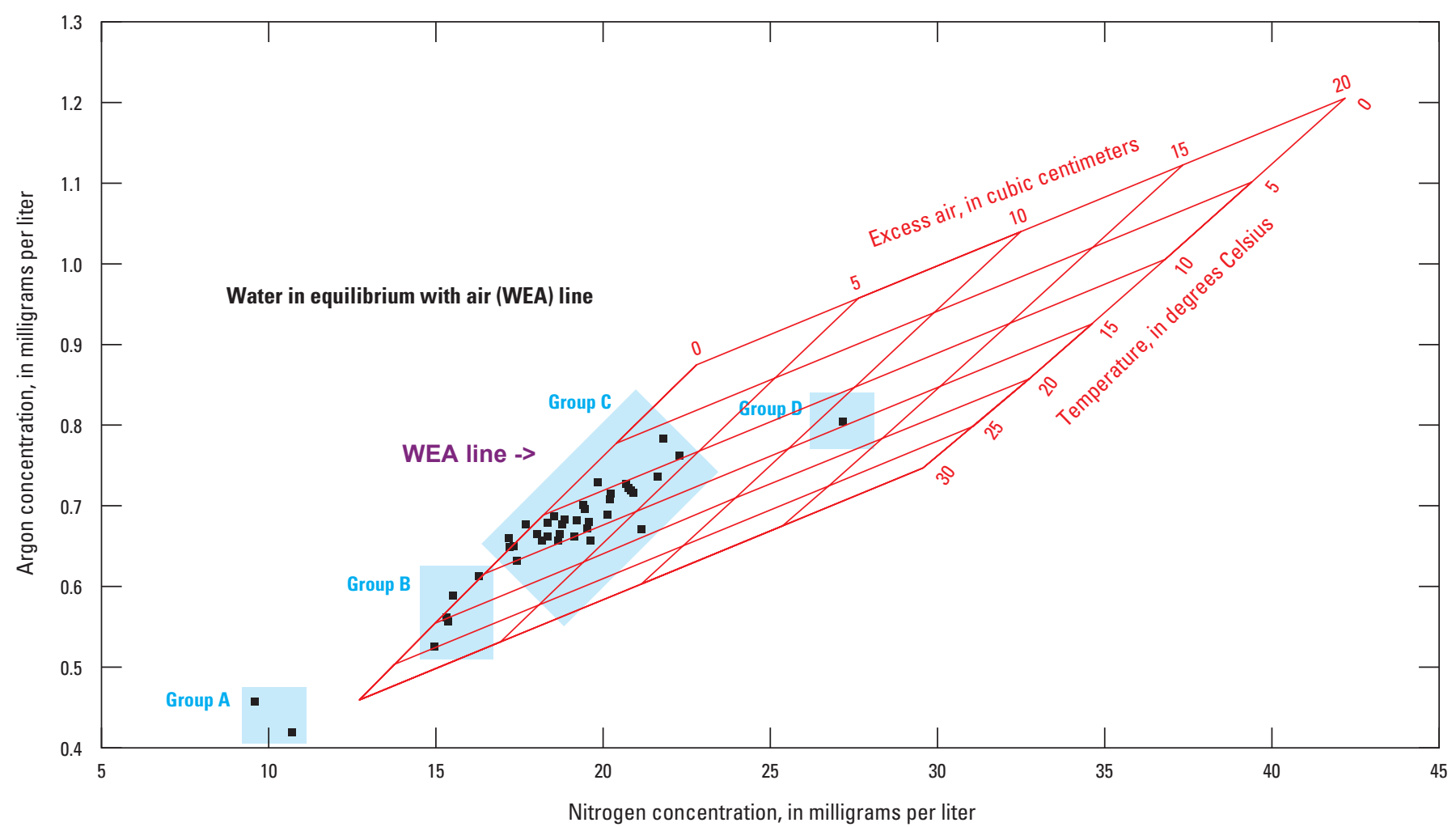

Figure 21. Concentrations of dissolved nitrogen in relation to concentrations of dissolved argon in samples from 39 wells and 2 springs collected as part of the baseline study, Monongahela River Basin, West Virginia, 2011, with associated estimates of recharge temperature and excess air, based on normalized sea-level concentrations. (WEA, water-in-equilibrium-with-air line; boxes labeled $A$ through $\mathrm{D}$ indicate groups of similar samples) 
little excess air and plot near the WEA line; only 1 of the 5 sites had a detectable concentration of methane. Two of the 5 sites are springs, and the remaining 3 sites are shallow wells with depths of 70, 80, and 145 feet. All five sites had warmer than average recharge-temperature estimates for groundwater in the study area, ranging from about $15^{\circ} \mathrm{C}$ to $25^{\circ} \mathrm{C}$, likely representing a significant component of recharge that occurred just prior to the sampling in June through September 2011.

Of the three remaining samples, two were clustered (group A, fig. 21) and the third was not associated with any group (fig. 21). The two samples of group A are enriched in methane and have partial pressures of atmospheric gases that are below equilibrium with the atmosphere. These samples have the highest concentrations of methane gas of the 41 wells sampled, $21.9 \mathrm{mg} / \mathrm{L}$ and $48.2 \mathrm{mg} / \mathrm{L}$. These samples likely reflect a mixture of shallow groundwater with a thermogenic gas component, possibly derived from deeper gas and hydrocarbon reservoirs. Low concentrations of atmospheric gases in these samples may also be partially a result of air stripping, whereby a portion of gases is carried along with the methane as it percolates upward from a hydrocarbon reservoir. The outlier sample (well Ups-0178) not associated with any group is distinguished from all other samples by a much higher than average $\mathrm{N}_{2}$ concentration, $27.2 \mathrm{mg} / \mathrm{L}$ compared to an average concentration of $18.6 \mathrm{mg} / \mathrm{L}$. None of the other atmospheric gases $\left(\mathrm{O}_{2}, \mathrm{CO}_{2}\right.$, and $\left.\mathrm{Ar}\right)$ were present in high concentrations. Methane was present at a concentration of $7.5 \mathrm{mg} / \mathrm{L}$ in water from well Ups-0178.

\section{Water-Quality Patterns}

The primary goal of this study was to describe groundwater and base-flow water quality during the early stages of shale-gas development. Water-quality data from early shalegas development then could be used for comparison with data collected later as development proceeds. The collection of the water-quality data has afforded an opportunity to examine patterns in water quality. Data from the groundwater survey and the base-flow survey were compared with historical data from sites in the study area to determine whether temporal changes had occurred. The base-flow survey was designed to facilitate a comparison of sites grouped by gas-production land use, and comparisons were made among these classifications. Additionally, groundwater survey data were examined using a multivariate analysis to discern relations among the water-quality data.

Patterns in groundwater quality were examined by comparing data collected in this study with data collected for other purposes, such as the West Virginia Ambient Groundwater Network database (Chambers and others, 2012), a principal components analysis, and a geospatial analysis of dissolved gas. The comparison of groundwater data from this study with historical data found no significant difference for any of the constituents examined and therefore warrant no further discussion. The PCA and the geospatial analysis are discussed below.

A PCA was conducted to discern patterns in groundwater quality. An initial PCA was run on all available groundwaterquality constituents and properties, including major ions, trace metals, dissolved gases, radionuclides, isotopes, and well depth. Correlations among variables also were assessed by computing correlation matrices. Variables with a majority of missing values or values below the laboratory reporting level, variables that contributed insignificantly to component loadings, or variables that exhibited no correlation with other variables were excluded from subsequent PCAs. The first two principal components from the final PCA explained 54 percent of the variance - principal component 1, 31 percent and principal component 2, 23 percent - within the data matrix (fig. 22).

The first principal component indicates gradients of redox conditions and dissolved solids concentrations with strong negative loadings for sodium, bromide, chloride, fluoride, barium, total dissolved solids, specific conductance, $\mathrm{pH}$, and methane, which were inversely proportional to dissolved oxygen, carbon dioxide, argon, nitrogen, and redox potential (table 8). This gradient may reflect a continuum from deeper waters with higher concentrations of sodium, barium, chloride, bromide, methane, and fluoride, constituents typically found in higher concentrations in deeper brines, and shallow, more dilute, more recent waters with higher concentrations of dissolved atmospheric gases. Whether this continuum reflects a typical gradient from recharge to shallow groundwaters to deeper groundwaters or indicates other pathways resulting in mixing of shallow groundwaters and deeper brines is unknown.

The second principal component had strong positive loadings for calcium, magnesium, potassium, iron, manganese, sulfate, total dissolved solids, specific conductance, argon, nitrogen, carbon dioxide, and hardness, and negative loadings for geologic age, methane, redox potential, bromide, and dissolved oxygen. In a pattern similar to the first principal component, the second component reflects a gradient from conditions typical of shallow groundwaters in the Appalachian region, which have high concentrations of total dissolved solids, iron, manganese, calcium, magnesium, and sulfate, to conditions more typical of deeper groundwaters. Carbonate dissolution and reduction of pyrite and siderite are dominant processes in the shallow aquifers of the region and can result in elevated concentrations of total dissolved solids, iron, calcium, and sulfate, whereas higher concentrations of chloride and bromide are more common in deeper waters. Because the primary cations and anions are inversely correlated with geologic age, this component may also reflect the effects of coal mining, which is prevalent in younger Pennsylvanian-age geologic formations, such as the Dunkard, Monongahela, Conemaugh, and Pottsville Groups, and the Allegheny, Kanawha, and New River Formations (fig. 2), all of which contain minable 


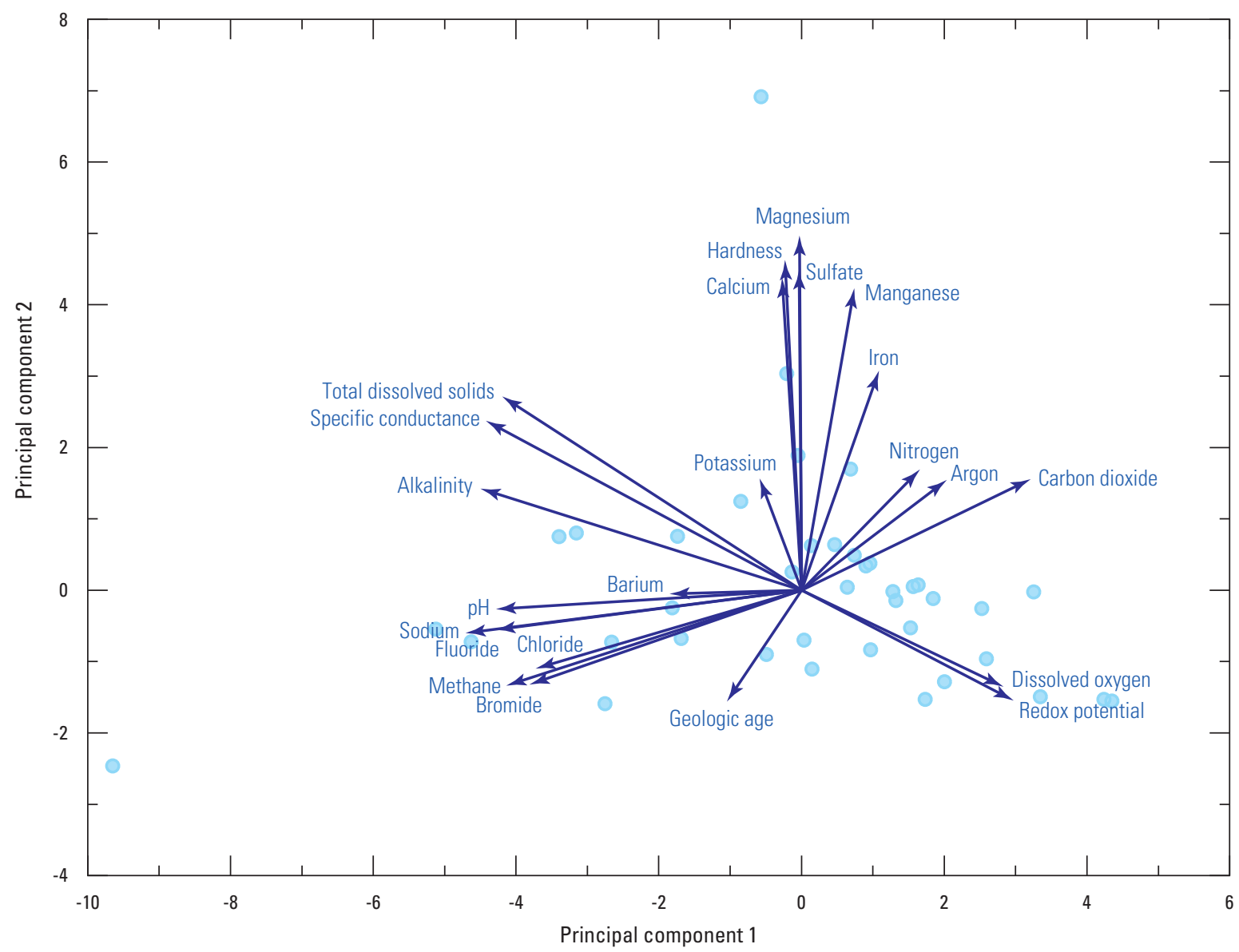

Figure 22. Principal component axis scores for the two principal components for selected groundwater samples collected as part of the Marcellus Shale baseline study, Monongahela River Basin, West Virginia, 2011.

Table 8. Principal component loadings from analysis of 23 variables potentially affecting groundwater quality in the Monongahela River Basin in West Virginia, 2011.

$\left[\mathrm{mg} / \mathrm{L}\right.$, milligrams per liter; $\mu \mathrm{S} / \mathrm{cm}$, microsiemens per centimeter at 25 degrees Celsius; $\mu \mathrm{g} / \mathrm{L}$, micrograms per liter; $\mathrm{mV}$, millivolts; $\mathrm{CaCO}_{3}$, calcium carbonate $]$

\begin{tabular}{|c|c|c|c|c|c|}
\hline Component name & $\begin{array}{l}\text { Component } 1 \\
\text { loadings }\end{array}$ & $\begin{array}{c}\text { Component } 2 \\
\text { loadings }\end{array}$ & Component name & $\begin{array}{c}\text { Component } 1 \\
\text { loadings }\end{array}$ & $\begin{array}{c}\text { Component } 2 \\
\text { loadings }\end{array}$ \\
\hline Specific conductance $(\mu \mathrm{S} / \mathrm{cm})$ & -0.311 & 0.194 & Magnesium (mg/L) & 1 & 0.405 \\
\hline $\mathrm{pH}$ (standard units) & -0.301 & 1 & Potassium (mg/L) & 1 & 0.128 \\
\hline Dissolved oxygen, field (mg/L) & 0.199 & -0.111 & Sodium (mg/L) & -0.331 & 1 \\
\hline $\operatorname{Argon}(\mathrm{mg} / \mathrm{L})$ & 0.143 & 0.126 & Alkalinity $\left(\mathrm{mg} / \mathrm{L}\right.$ as $\left.\mathrm{CaCO}_{3}\right)$ & -0.316 & 0.116 \\
\hline Methane $(\mathrm{mg} / \mathrm{L})$ & -0.291 & -0.109 & Fluoride (mg/L) & -0.301 & 1 \\
\hline Geologic age $^{2}$ & 1 & -0.128 & Sulfate (mg/L) & 1 & 0.367 \\
\hline Redox Potential (mV) & 0.209 & -0.126 & Barium $(\mu \mathrm{g} / \mathrm{L})$ & -0.130 & 1 \\
\hline Total dissolved solids (mg/L) & -0.295 & 0.221 & $\operatorname{Iron}(\mu \mathrm{g} / \mathrm{L})$ & 1 & 0.251 \\
\hline
\end{tabular}

${ }^{1}$ Loadings less than 0.100 were not considered relevant and were not included.

${ }^{2}$ Geologic age used in this analysis is based on relative age of the geologic formation or group in millions of years. 
coal seams. Mississippian- and Devonian-aged rocks within the study area do not contain minable coal seams.

The presence of constituents often associated with deeper brines, as indicated by the first principal component discussed above, and the frequent presence of methane in groundwater survey samples (56 percent of samples) may indicate mixing of a very small component of deeper groundwater with shallow groundwater. Bromide and methane frequently were present in the same groundwater samples.

To assess the potential for migration of brine waters and associated methane gas from deeper geologic strata or from shallow coal seams, the location of wells with elevated concentrations of methane were plotted on a map (fig. 23), along with the location of mined coal seams and shallow and deep structural geologic features (faults, synclines, and anticlines). None of the wells with samples containing methane concentrations greater than $1.0 \mathrm{mg} / \mathrm{L}$ are located within the footprint of current or abandoned underground or surface mines. The highest concentration of methane $(48.2 \mathrm{mg} / \mathrm{L})$ detected in this study was from a well (Ran-0276) at the southern end of the Elkins Valley Anticline. A nearby well (Ran-0278) also had an elevated concentration $(8.39 \mathrm{mg} / \mathrm{L})$ of methane. A thrust fault cuts through numerous formations, including the Marcellus Shale, and is expressed at the surface in the crest of the Elkins Valley Anticline (Ryder and others, 2008). However, no clear pattern linking methane concentrations to the presence of a geologic structure was noted because there were an approximately equal number of samples with detectable concentrations of methane from wells not located in or near geologic structures as there were samples from wells located in such structures.

No strong patterns were noted in the base-flow survey data. There were significant differences for some constituents in comparison to historical water-quality data or in comparisons among gas-production bins. Although there were no strong patterns obvious in the base-flow data, some more subtle patterns that may represent early changes in water quality as shale gas development proceeds were observed. These subtle patterns may warrant closer scrutiny as development intensifies and the effects of this development are realized over time.

Coal mining continues to exert a strong effect on water quality in the Monongahela River Basin (Anderson and others, 2000). A simple mining intensity index was developed for this report; mined areas in all the coal seams (West Virginia Geological and Economic Survey, 2011b) within a HUC-12 were summed, divided by the total surface area in the HUC-12, and expressed as a percentage. Values greater than 100 percent represent those areas where multiple seams that had been mined exceeded the overall surface area. No attempt was made to account for thickness, mining method or time, or mine discharge location. Had the primary focus of this study been on exploring the effects of coal mining on water quality, accounting for these factors would have allowed the development of a more sophisticated index. Mining intensity was significantly related to sulfate concentration and specific conductance (fig. 24); both characteristics are related to mining in other studies (Anderson and others, 2000; McAuley and Kozar, 2006; Cravotta, 2008a).

Values for $\mathrm{pH}$, chloride, and strontium from the base-flow survey were all significantly higher than historical data for the Monongahela River Basin. Higher pHs in base-flow survey samples are likely due to changes in coal-mining practices and treatment of mine drainage. The historical dataset spans a period of time before and through the implementation of mine regulation under the United States Surface Mine Control and Reclamation Act of 1977 (30 U.S.C. 1201-1328; 91 Stat.). Chloride and strontium are constituents associated with deep brines (Engle and Rowan, 2013). Increases in chloride concentrations may have many causes, including mine discharges. The increase in strontium is unlikely to be due to coal mining. Possible mechanisms for increases in deep-brine constituents in surface waters include upward migration of brines through faults and fractures, upward migration of brines along improperly constructed or sealed gas wells, and accidental discharge of well brines to surface waters. Further study would be necessary to determine the source of increased concentrations of chloride and strontium and mechanisms through which they enter surface water.

Concentrations of fluoride and barium, both constituents associated with deep brines (Engle and Rowan, 2013), varied significantly among base-flow survey samples grouped by gasproduction bins. In the case of fluoride and barium, concentrations were significantly higher in the Near Production bin than in either the Production or Not Near Production bins. Further study would be needed to extrapolate this pattern.

Any similarity between the groundwaters and surface waters of a region are likely to be most evident in base flow. The stable isotope compositions of the groundwater- and surface-water base-flow survey samples were similar to one another as well as to precipitation in the area. Although the stable isotope composition indicates similar sources of the waters sampled in this study, the major ion compositions of the groundwater survey samples and the base-flow survey samples show distinct differences. Sulfate was the dominant anion in a greater proportion of base-flow survey samples than in groundwater survey samples and may reflect coal-mining land uses and the effects of mine drainage.

Further studies in this area could focus on deep brine constituents, examine the possibilities of flow-path alteration and inter-basin transfers of water, and more thoroughly investigate the influence of legacy gas wells in the region. The USGS is currently (2013-14) investigating the possibility of inter-basin transfer of water in the area, a study prompted by an examination of streamflow data collected as part of this study. 


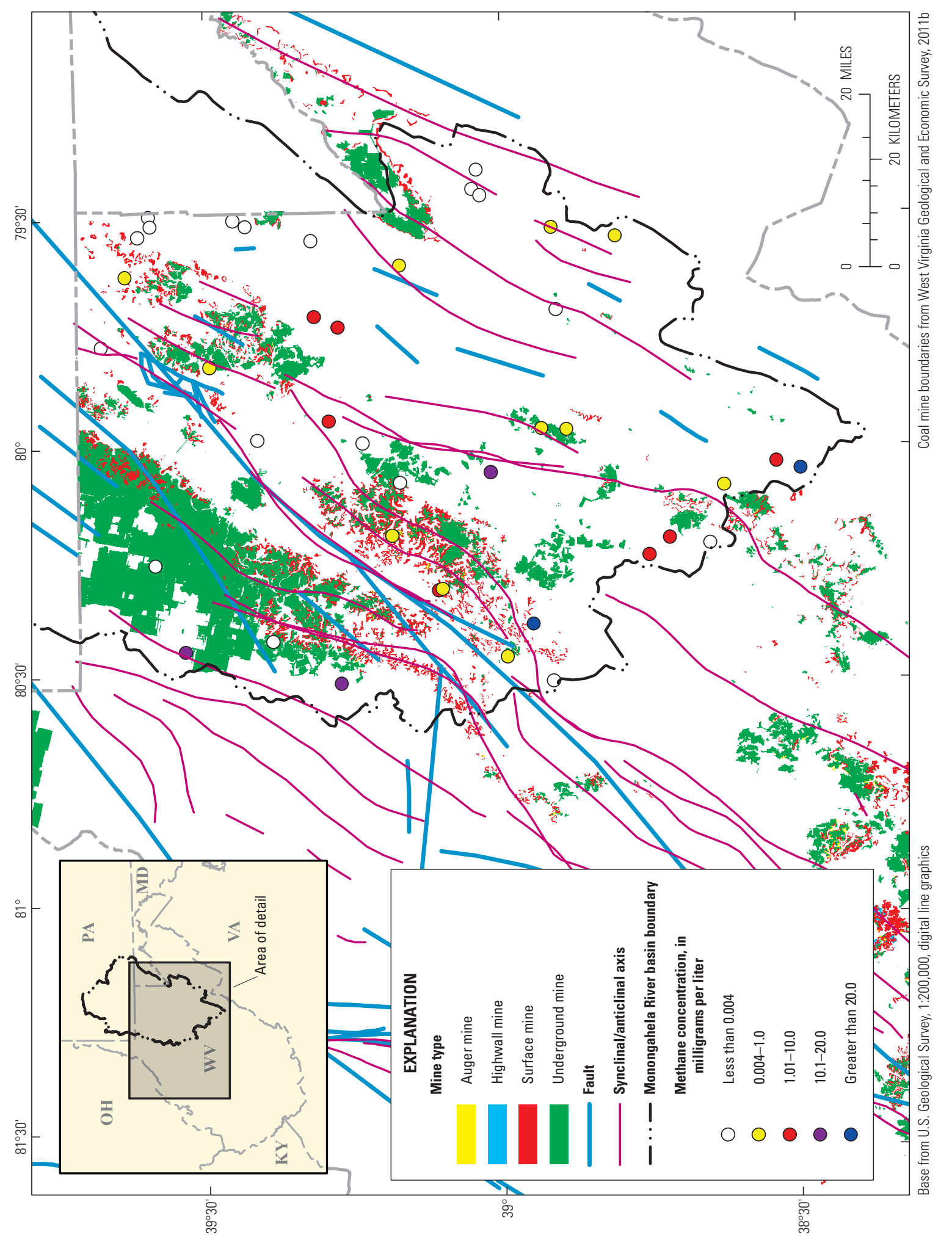

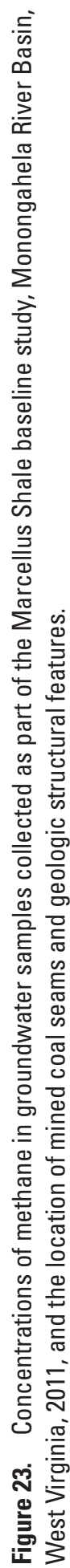



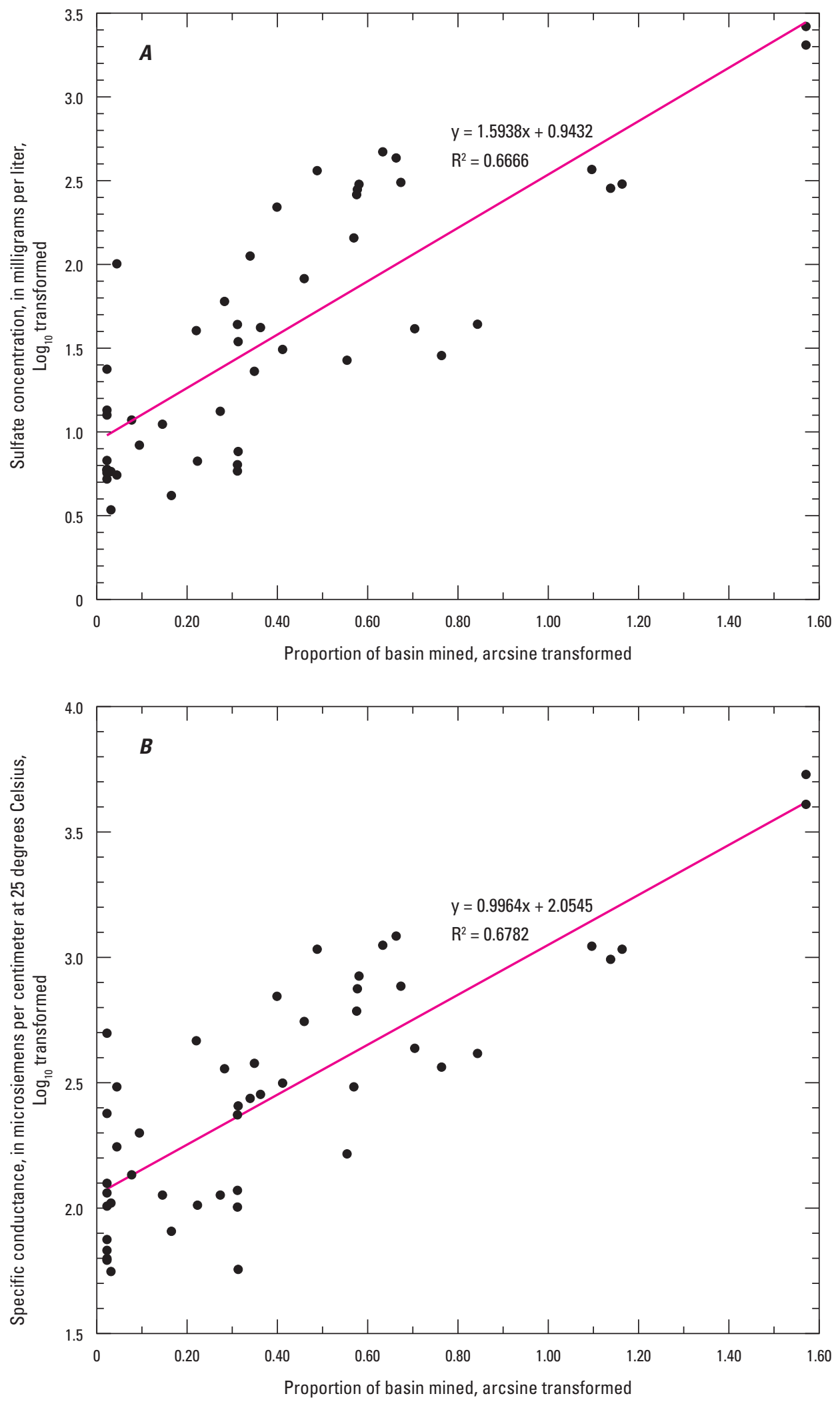

Figure 24. Concentration of constituent or property in relation to the mining intensity, measured as the sum of mined areas in the 12-digit hydrologic unit code (HUC-12) areas, expressed as a proportion of the HUC-12 surface area for $A$, sulfate and $B$, specific conductance in base-flow samples collected as part of the Marcellus Shale baseline survey, Monongahela River Basin, West Virginia, 2012. 


\section{Summary}

The Marcellus Shale gas field underlies parts of New York, Pennsylvania, Ohio, Virginia, Maryland, Tennessee, and West Virginia. Development of hydraulic fracturing and horizontal drilling technology led to extensive development of gas in the Marcellus Shale beginning about 2007. A recent assessment estimated that 84,198 billion cubic feet of natural gas were recoverable from the Marcellus Shale, enough natural gas to meet the needs of the entire Nation for about 15 years. The recovery of this gas is not without potential environmental consequences, including contamination of water resources by flowback water, hydraulic fracturing fluids, radioactivity in shale waste, and fluid waste disposal.

The primary goal of this study, conducted by the U.S. Geological Survey (USGS), in cooperation with the West Virginia Department of Environmental Protection, Division of Water and Waste Management, was to establish a baseline of water-quality conditions in West Virginia's Monongahela River Basin, an area of intensive development of the Marcellus Shale gas field. Groundwater (39 wells and 2 springs) and streamwater under base-flow conditions (50 stream sampling sites) were sampled, and the samples were analyzed for a broad suite of major ions, trace elements, naturally occurring radioactive materials (NORMs), and stable isotopes that can be used as markers for the potential effects of shale gas recovery. The baseline study, conducted during 2011-12, is intended to serve as a point of comparison for samples collected as the development of the Marcellus Shale gas field continues.

In addition to describing baseline conditions, results of water-quality analyses of samples collected during the groundwater and surface-water base-flow surveys were compared to historical water-quality data from USGS National Water Information System (NWIS) databases. The base-flow results were also examined for differences among gas-production classifications. Although no significant differences were observed in comparisons of groundwater survey data with historical data, there were a few significant differences for base-flow data, either with historical data or by Marcellus Shale gas-production classification (bins); the classification scheme did not account for conventional gas wells. The results for $\mathrm{pH}$, chloride, and strontium were significantly higher in the base-flow survey samples than in the historical data. In a comparison of base-flow survey results classified by gas production, fluoride and barium were higher in bins with gas production than either bins adjacent to basins producing gas or bins neither producing gas nor adjacent to gas-producing bins. Four constituents that had a significant difference $(\mathrm{p}<0.1)$ - chloride, strontium, fluoride, and barium - either compared to historical data or by gas-production category are often associated with deep saline groundwater. Saline water occurs naturally within 300 feet of the land surface in parts of the study area.

All samples were analyzed for total uranium. If uranium was detected in a sample, that sample was further analyzed for uranium and radium isotopes. One sample from well Pre-0163, exceeded the 5.0 picocuries per liter (pCi/L) U.S. Environmental Protection Agency (EPA) maximum contaminant level (MCL) with a combined value of Ra-226 and Ra-228 of $5.1 \mathrm{pCi} / \mathrm{L}$. Other than 3 samples, 2 from the groundwater survey and 1 from the base-flow survey, that exceeded $1.0 \mathrm{pCi} / \mathrm{L}$ with either a single value of Ra-226 or Ra-228 or combined value, NORMs were not elevated above background levels in either groundwater or base-flow samples.

The composition of hydrogen and oxygen isotopes in groundwater samples shows signatures similar to those of the precipitation and river water in the area. The overall signatures in groundwater reflect both local effects and a Great Lakes signature affecting precipitation and, therefore, groundwater recharge. Additionally, no major deviations from the Global Meteoric Water Line were observed for base-flow samples, indicating that meteoric water and shallow groundwater represent a major component in these streams.

Isotope analysis showed no clear indication of mixing of shallow groundwater and deep groundwater brines, which are found in the Marcellus Shale. None of the water samples had preferential enrichment of $\delta^{18} \mathrm{O}_{\mathrm{H} 2 \mathrm{O}}$ over $\delta^{2} \mathrm{H}_{\mathrm{H} 2 \mathrm{O}}$, which is seen in the deep brines of the area. Furthermore, no water samples had positive $\delta^{13} \mathrm{C}_{\mathrm{DIC}}$ signatures similar to those of flowback water from Marcellus Shale operations. The isotopic signatures of the 11 methane samples from this study are generally similar to the isotopic signatures of coal-bed methane, typically a mixture of methane produced by both biogenic and thermogenic processes, or a mixture of coal-bed methane, biogenic, and thermogenic methane. Also, no pattern was observed in a comparison of concentrations of $\delta^{18} \mathrm{O}_{\mathrm{SO} 4}$ and concentrations of $\delta^{34} \mathrm{~S}_{\mathrm{SO} 4}$ among Marcellus Shale gas-production bins. However, the interpretation of sulfate data was possibly confounded by reducing conditions and bacterial reduction of sulfate in mine pools, potentially altering sulfate signatures.

Dissolved-gas analyses indicate that most of the groundwater samples, 38 of 41 , were from a shallow groundwater source. Of these 38 samples, 33 had dissolved gas profiles similar to those of typical shallow groundwater found in domestic wells within the study area. The remaining 5 samples, 2 of which were springs, were estimated to have had a significant component of recharge that occurred just prior to the sampling in June through September 2011. Of the three sites not having a typical shallow groundwater dissolved gas profile, two were enriched in methane and the third had a greater than average concentration of nitrogen.

This study represents a "snap shot in time," an indication of regional water-quality conditions early in the development of the Marcellus Shale gas field. Changes in water quality may result from this development and without a set of baseline conditions these changes cannot be reliably discerned. Although not all encompassing, this dataset should provide a sufficient baseline to be used to identify changes in water quality as gas field development proceeds, regardless of whether the changes are due to the intensity of development or the changes are those that would occur over time. 


\section{References Cited}

Anderson, R.M., Beer, K.M., Buckwalter, T.F., Clark, M.E., McAuley, S.D., Sams, J.I., III, and Williams, D.R., 2000, Water Quality in the Allegheny and Monongahela River Basins Pennsylvania, West Virginia, New York, and Maryland, 1996-98: U.S. Geological Survey Circular 1202, 32 p.

Atekwana, E. A., and Krishnamurthy, R.V., 1998, Seasonal variations of dissolved inorganic carbon and ${ }^{13} \mathrm{C}$ of surface waters: application of a modified gas evolution technique: Journal of Hydrology, v. 205, p. 265-278.

Bain, G.L., 1970, Salty ground water in the Pocatalico River basin: West Virginia Geological and Economic Survey, Circular 11, $31 \mathrm{p}$.

Busenberg, E., Plummer, L.N., and Bartholomay, R.C., 2001, Estimated age and source of the young fraction of ground water at the Idaho National Engineering and Environmental Laboratory: U.S. Geological Survey Water-Resources Investigations Report 01-4265, 144 p.

Cardwell, D.H., Erwin, R.B., Woodward, H.P., and Lotz, C.W., 1968, Geologic map of West Virginia: West Virginia Geological and Economic Survey, 2 sheets, scale 1:250,000, digital data created in 1998 by the West Virginia Department of Environmental Protection, accessed September 9, 2001, at http://wvgis.wvu.edu.

Chambers, D.B., Kozar, M.D., White, J.S., and Paybins, K.S., 2012, Groundwater quality in West Virginia, 1993-2008: U.S. Geological Survey Scientific Investigations Report 2012-5186, 47 p.

Clark, I.D., and Fritz, P., 1997, Environmental Isotopes in Hydrogeology: Danvers, Mass., CRC Press/Lewis Publishers, $328 \mathrm{p}$.

Coleman, D.D., 1994, Advances in the use of geochemical fingerprinting for gas identification: Isotech Laboratories, Inc., at American Gas Association Operations Conference, 10 p.

Coleman, J.L., Milici, R.C., Cook, T.A., Charpentier, R.R., Kirschbaum, Mark, Klett, T.R., Pollastro, R.M., and Schenk, C.J., 2011, Assessment of undiscovered oil and gas resources of the Devonian Marcellus Shale of the Appalachian Basin Province, 2011: U.S. Geological Survey Fact Sheet 2011-3092, 2 p., accessed February 6, 2014, at http:// pubs.usgs.gov/fs/2011/3092/.

Craig, H., 1961, Isotopic variations in meteoric waters: Science, v. 133, p. 1702-1703.

Cravotta, C.A., 2008a, Dissolved metals and associated constituents in abandoned coal-mine discharges, Pennsylvania, USA. Part 1: Constituent quantities and correlations: Applied Geochemistry, v. 23, p. 166-202.
Cravotta, C.A., 2008b, Dissolved metals and associated constituents in abandoned coal-mine discharges, Pennsylvania, USA. Part 2: Geochemical controls on constituent concentrations: Applied Geochemistry, v. 23, p. 203-226.

Dansgaard, W., 1964, Stable isotopes in precipitation: Tellus, v. 16 , no. 4 , p. 436-468.

Doctor, D.H., Kendall, C., Sebestyen, S.D., Shanley, J.B., Ohte, N., and Boyer, E.W., 2008, Carbon isotope fractionation of dissolved inorganic carbon (DIC) due to outgassing of carbon dioxide from a headwater stream: Hydrological Processes, v. 2423, p. 2410-2423.

Dresel, E., and Rose, A.W., 2010, Chemistry and origin of oil and gas brines in Western Pennsylvania: Pennsylvania Geological Survey, 4th ser., Open-File Report OFOG 10-01.0, $48 \mathrm{p}$.

Engle, M.A., and Rowan, E.L., 2013, Geochemical evolution of produced water from the hydraulic fracturing of the Marcellus Shale, northern Appalachian Basin-A multivariate compositional data analysis approach: International Journal of Coal Geology, v. 126, p. 45-46.

Federal Register, 2001, National Primary Drinking Water Regulations, arsenic and clarifications to compliance and new source contaminants monitoring; Final rule: Federal Register, January 22, 2001, v. 66, no., 14, p. 6975-7066.

Fenneman, N.M., 1938, Physiography of the eastern United States: New York, McGraw-Hill, 714 p.

Fenneman, N.M., and Johnson, D.W., 1946, Physical divisions of the United States: U.S. Geological Survey Physiography Committee Special Map, scale 1:7,000,000, accessed September 20, 1999, at http://water.usgs.gov/lookup/ getspatial?physio.

Foster, J.B., 1980, Fresh and saline ground water map of West Virginia: West Virginia Geological and Economic Survey map report WV-12, 4 plates.

Gu, A., Gray, F., Eastoe, C.J., Norman, L.M., Duarte, O., and Long, A., 2008, Tracing ground water input to base flow using sulfate $(\mathrm{S}, \mathrm{O})$ isotopes: Groundwater, v. 46, no. 3, p. 502-509.

Hem, J.D., 1985, Study and interpretation of the chemical characteristics of natural water: U.S. Geological Survey Water-Supply Paper 2254, 263 p.

Kappel, W.M., Williams, J.H., and Szabo, Zoltan, 2013, Water resources and shale gas/oil production in the Appalachian Basin-Critical issues and evolving developments: U.S. Geological Survey Open-File Report 2013-1137, p. 12, accessed November 2013 at http://pubs.usgs.gov/ of/2013/1137. 
Kendall, C., and Coplen, T.B., 2001, Distribution of oxygen-18 and deuterium in river waters across the United States: Hydrological Processes, v. 15, p. 1363-1393.

Koterba, M.T., Wilde, F.D., and Lapham, W.W., 1995, Ground-water data-collection protocols and procedures for the National Water-Quality Assessment Program - Collection and documentation of water-quality samples and related data: U.S. Geological Survey Open-File Report 95-399, $113 \mathrm{p}$.

Kozar, M.D., and Brown, D.P., 1995, Location and site characteristics of the ambient ground-water-quality-monitoring network in West Virginia: U.S. Geological Survey OpenFile Report 95-130, 48 p.

Kozar, M.D., McCoy, K.J., Britton, J.Q., and Blake, B.M. Jr., 2013, Hydrogeology, groundwater flow, and groundwater quality of an abandoned underground coal-mine aquifer, Elkhorn Area, West Virginia: Morgantown, W.Va., West Virginia Geological and Economic Survey, Bulletin Number B-46.

Kroopnick, P., and Craig, H., 1972, Atmospheric oxygen: Isotopic composition and solubility fractionation: Science, v. 175 , p. $54-55$.

Lambert, D.C., McDonough, K.M., and Dzombak, D.A., 2004, Long-term changes in quality of discharge water from abandoned underground coal mines in Uniontown Syncline, Fayette County, PA, USA: Water Research, v. 38, p. 277-288.

Llewellyn, G.T., 2014, Evidence and mechanisms for Appalachian Basin brine migration into shallow aquifers in NE Pennsylvania, USA: Hydrogeology Journal, v. 22, p. 1055-1066.

McAuley, S.D., and Kozar, M.D., 2006, Ground-water quality in unmined areas and near reclaimed surface coal mines in the northern and central Appalachian coal regions, Pennsylvania and West Virginia: U.S. Geological Survey Scientific Investigations Report 2006-5059, $57 \mathrm{p}$.

McColloch, J.S., Binns, R.D., Jr., Blake, B.M., Jr., Clifford, M.T., and Gooding, S.E., 2012, West Virginia Mine Pool Atlas: West Virginia Geological and Economic Survey Final Project Report, accessed June 5, 2014, at http://www.dep. wv.gov/WWE/wateruse/Documents/MinePoolAtlas.pdf.

McCoy, K.J., and Kozar, M.D., 2007, Relation of chlorofluorocarbon age dates to water quality in aquifers of West Virginia: U.S. Geological Survey Scientific Investigations Report 2006-5221, 36 p.

Milici, R.C., and Dennen, K.O., 2009, Production and depletion of Appalachian and Illinois Basin coal resources, in Pierce, B.S., and Dennen, K.O., eds., The national coal resource assessment overview: U.S. Geological Survey Professional Paper 1625-F, Chapter H, 18 p.
Molofsky, L.J., Connor, J.A., Farhat, S.K., Wylie, A.S., Jr., and Wagner, T., 2011, Methane in Pennsylvania water wells unrelated to Marcellus Shale fracturing: Oil \& Gas Journal, v. December 5, 2011, p. 1-13.

Mulder, M.L., 2012, Ambient geochemical and isotopic variations in groundwaters across an area of accelerating shale gas development: Morgantown, W.Va., West Virginia University, Master's Thesis, 90 p.

National Agricultural Statistics Service, 2014, 2012 Census of agriculture West Virginia State and county data: Volume 1, Geographic area series part 48, AC-12-A-48, accessed June 5, 2014, at http://www.agcensus.usda.gov/ Publications/2012/Full_Report/Volume_1,_Chapter_2_ County_Level/West_Virginia/wvv1.pdf.

National Research Council, 2001, Arsenic in drinking water2001 update: Washington, D.C., National Academy Press, $226 \mathrm{p}$.

Pelak, A.J., 2014, Geochemical and isotopic variations in surface waters of the Monongahela River Basin: An area of accelerating Marcellus Shale development in West Virginia: Morgantown, W.Va., West Virginia University Master's Thesis, $64 \mathrm{p}$.

Pelak, A.J., and Sharma, S., 2014, Surface water geochemical and isotopic variations in an area of accelerating Marcellus Shale gas development: Environmental Pollution, v. 195, p. 1-10.

Price, P.H., Hare, C.E., McCue, J.B., and Hoskins, H.A., 1937, Salt brines of West Virginia: West Virginia Geological Survey, 203 p.

PRISM Climate Group, 2012, Precipitation - annual climatology (1981-2010), accessed August 26, 2013, at http://www. prism.oregonstate.edu/normals/.

Rowan, E.L., Engle, M.A., Kirby, C.S., and Kraemer, T.F., 2011, Radium content of oil- and gas-field produced waters in the northern Appalachian Basin (USA) - Summary and discussion of data: U.S. Geological Survey Scientific Investigations Report 2011-5135, $31 \mathrm{p}$.

Ryder, R.T., Swezey, C.S., Crangle, R.D., Jr., and Trippi, M.H., 2008, Geologic cross section E-E' through the Appalachian basin from the Findlay arch, Wood County, Ohio, to the Valley and Ridge province, Pendleton County, West Virginia: U.S. Geological Survey Scientific Investigations Map 2985, 2 sheets, 48-p. pamphlet. 
Ryder, R.T., Crangle, R.D., Jr., Trippi, M.H., Swezey, C.S., Lentz, E.E., Rowan, E.L., and Hope, R.S., 2009, Geologic cross section $D-D$ ' through the Appalachian basin from the Findlay arch, Sandusky County, Ohio, to the Valley and Ridge province, Hardy County, West Virginia: U.S. Geological Survey Scientific Investigations Map 3067, 2 sheets, 52-p. pamphlet.

Schenk, C.J., and Pollastro, R.M., 2002, Natural gas production in the United States: U.S. Geological Survey Fact Sheet FS-113-01, January 2002, 2 p., accessed February 6, 2014, at http://pubs.usgs.gov/fs/fs-0113-01/.

Schwietering, J.F., and Bocan, J.M., 2011, Thickness contours, polygons (Plate_7, augmented), Marcellus Shale, West Virginia digital dataset: West Virginia Geologic and Economic Survey Open File Report 8608, accessed September 5, 2012, at http://www.wvgs.wvnet.edu/www/datastat/ devshales.htm.

Sharma, S., Mulder, M.L., Sack, A., Schroeder, K.T., and Hammack, R. W., 2013a, Isotope approach to assess hydrologic connections during Marcellus Shale drilling: Groundwater, v. 52, p. $424-433$.

Sharma, Shikha, Sack, A., Adams, J.P., Vesper, D.J., Capo, R.C., Hartsock, A., and Edenborn, H.M., 2013b, Isotopic evidence of enhanced carbonate dissolution at a coal mine drainage site in Allegheny County, Pennsylvania, USA: Applied Geochemistry, v. 29, p. 32-42.

Sharma, S., Mulder, M.L., Sack, A., Schroeder, K.T., and Hammack, R.W., 2014a, Isotope approach to assess hydrologic connections during Marcellus Shale drilling: Groundwater, v. 52, p. $424-433$.

Sharma S., Bowman L., Schroeder K., Hammack R., 2014b, Assessing changes in gas migration pathways at a hydraulic fracturing site: Example from Greene County, Pennsylvania: Applied Geochemistry, accessed September 4, 2014 at doi: 10.1016/j.geochem.2014.07.018.

Tewalt, S.J., Ruppert, L.F., Bragg, L.J., Carlton, R.W., Brezinski, D.K., Wallack, R.N., and Butler, D.T., 2001, Chapter C-A digital resource model of the Upper Pennsylvanian Pittsburgh coal bed, Monongahela Group, northern Appalachian Basin coal region, in Northern and Central Appalachian Basin Coal Regions Assessment Team, 2000 resource assessment of selected coal beds and zones in the northern and central Appalachian Basin coal regions: U.S. Geological Survey Professional Paper 1625-C, CD-ROM, version 1.0.

TIBCO Software Inc., 2008, TIBCO Spotfire S-PLUS® 8.1 guide to stats, volumes 1 and 2: Palo Alto, Calif., TIBCO Software Inc. p. 558.
Toran, L., and Harris, R.F., 1989, Interpretation of sulfur and oxygen isotopes in biological and abiological sulfide oxidation: Geochimica et Cosmochimica Acta, v. 53, p. 2341-2348.

U.S. Census Bureau, 2014, State and County QuickFacts, accessed June 5, 2014, at http://quickfacts.census.gov/qfd/ index.html.

U.S. Department of Energy, 2013, Modern shale gas development in the United States: An update: National Energy Technology Laboratory, 79 p., accessed January 22, 2014, at http://www.netl.doe.gov/File\%20Library/Research/Oil-Gas/ shale-gas-primer-update-2013.pdf.

U.S. Energy Information Administration, 1999, Natural gas 1998 - Issues and trends, 260 p., accessed November 13, 2013, at http://www.eia.doe.gov/oil_gas/natural_gas/ analysis_publications/natural_gas_1998_issues_and_trends/ it98.html.

U.S. Energy Information Administration, 2004, The basics of underground natural gas storage, accessed December 23, 2014, at http://www.eia.gov/pub/oil_gas/natural_gas/ analysis_publications/storagebasics/storagebasics.html.

U.S. Energy Information Administration, 2012, What is shale gas and why is it important, accessed June 5, 2014, at http:// www.eia.gov/energy_in_brief/article/about_shale_gas.cfm.

U.S. Energy Information Administration, 2014, Underground natural gas storage, accessed June 5, 2014, at http://www. eia.gov/pub/oil_gas/natural_gas/analysis_publications/ ngpipeline/undrgrnd_storage.html.

U.S. Environmental Protection Agency, 2009, National Primary Drinking Water Regulations, accessed February 11, 2011, at http://www.epa.gov/ogwdw/consumer/pdf/mcl.pdf.

U.S. Environmental Protection Agency, 2013, The Watershed Boundary Dataset (WBD) was created from a variety of sources from each state and aggregated into a standard national layer for use in strategic planning and accountability, accessed April 30, 2013, at http://datagateway.nrcs.usda. gov.

U.S. Geological Survey, 2005a, Hydrologic units (watersheds), two million scale, accessed April 2, 2014, at http:// nationalatlas.gov/atlasftp.html.

U.S. Geological Survey, 2005b, Streams and waterbodies, two million scale, accessed April 2, 2014, at http://nationalatlas. gov/atlasftp.html.

U.S. Geological Survey, 2006, Collection of water samples (ver. 2.0): U.S. Geological Survey Techniques of WaterResources Investigations, book 9, chap. A4, September 2006, accessed March, 20, 2014, at http://pubs.water.usgs. gov/twri9A4/. 
Warner, N.R., Jackson, R.B., Darrah, T.H., Osborn, S.G., Down, Adrian, Zhao, Kaigung, White, Alissa, and Vengosh, Avner, 2012, Geochemical evidence for possible natural migration of Marcellus Formation brine to shallow aquifers in Pennsylvania: Proceedings of the National Academy of Sciences of the United States of America, v. 109, p. 11961-11966.

West Virginia Department of Environmental Protection, 2010, Industry guidance, gas well drilling/completion, large water volume fracture treatments, accessed June 9, 2014, at http:// www.dep.wv.gov/oil-and-gas/GI/Documents/Marcellus $\% 20$ Guidance\%201-8-10\%20Final.pdf.

West Virginia Department of Environmental Protection, 2013, Office of Oil and Gas, accessed April 2, 2014, at http:// www.dep.wv.gov/oil-and-gas/Pages/default.aspx.

West Virginia Geological and Economic Survey, 2011a, Schwietering Thickness Contours, Polygons (Plate_7, Augmented), Marcellus Shale, West Virginia, accessed March 2012 at http://www.wvgs.wvnet.edu/www/datastat/ devshales.htm.

West Virginia Geological and Economic Survey, 2011b, Coal bed mapping program (CBMP) interactive mapping services, accessed March 18, 2014, at http://www.wvgs.wvnet. edu/www/coal/cbmp/coalims.html.

West Virginia Geological and Economic Survey, 2012, Marcellus wells monthly production data, accessed June 4, 2012, at http://www.wvgs.wvnet.edu/www/datastat/ devshales.htm\#Data.

West Virginia Geological and Economic Survey, 2014a, Digital data on the distribution of wells completed in the Marcellus Shale Formation in West Virginia: digital data accessed March 18, 2014, at http://www.wvgs.wvnet.edu/ www/datastat/devshales.htm\#Data.

West Virginia Geological and Economic Survey, 2014b, West Virginia Geology — Physiographic Provinces, accessed March 2014 at http://www.wvgs.wvnet.edu/www/geology/ geolphyp.htm.

White, I.C., 1904, Petroleum and natural gas precise levels, volume 1, A: West Virginia Geological Survey, p. 625.

Whiticar, M.J., 1999, Carbon and hydrogen isotope systematics of bacterial formation and oxidation of methane: Chemical Geology, 161, p. 291-314.

Wilde, F.D., Radtke, D.B., Gibs, Jacob, and Iwatsubo, R.T., eds., 2004 with updates through 2009, Processing of water samples (ver. 2.2): U.S. Geological Survey Techniques of Water-Resources Investigations, book 9, chap. A5, accessed March 20, 2014, at http://pubs.water.usgs.gov/twri9A5/.
Wilmoth, B.M., 1975, Development of fresh ground water near salt water in West Virginia: Ground Water, v. 13, p. $25-32$.

World Health Organization, 2006, Guidelines for drinkingwater quality, $3 \mathrm{~d}$ ed., incorporating first and second addenda: Volume 1-Recommendations: Geneva, World Health Organization, 494 p. 


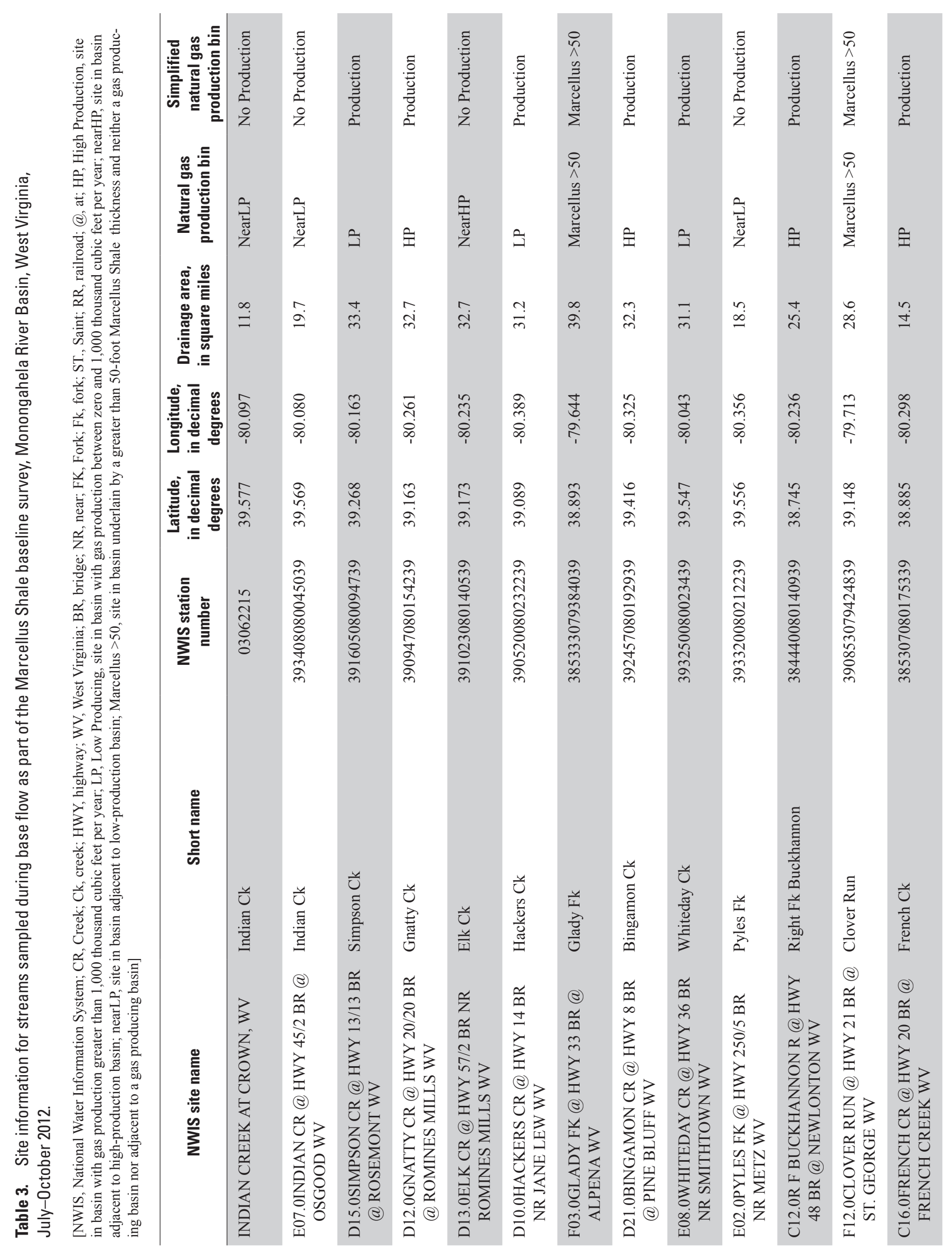




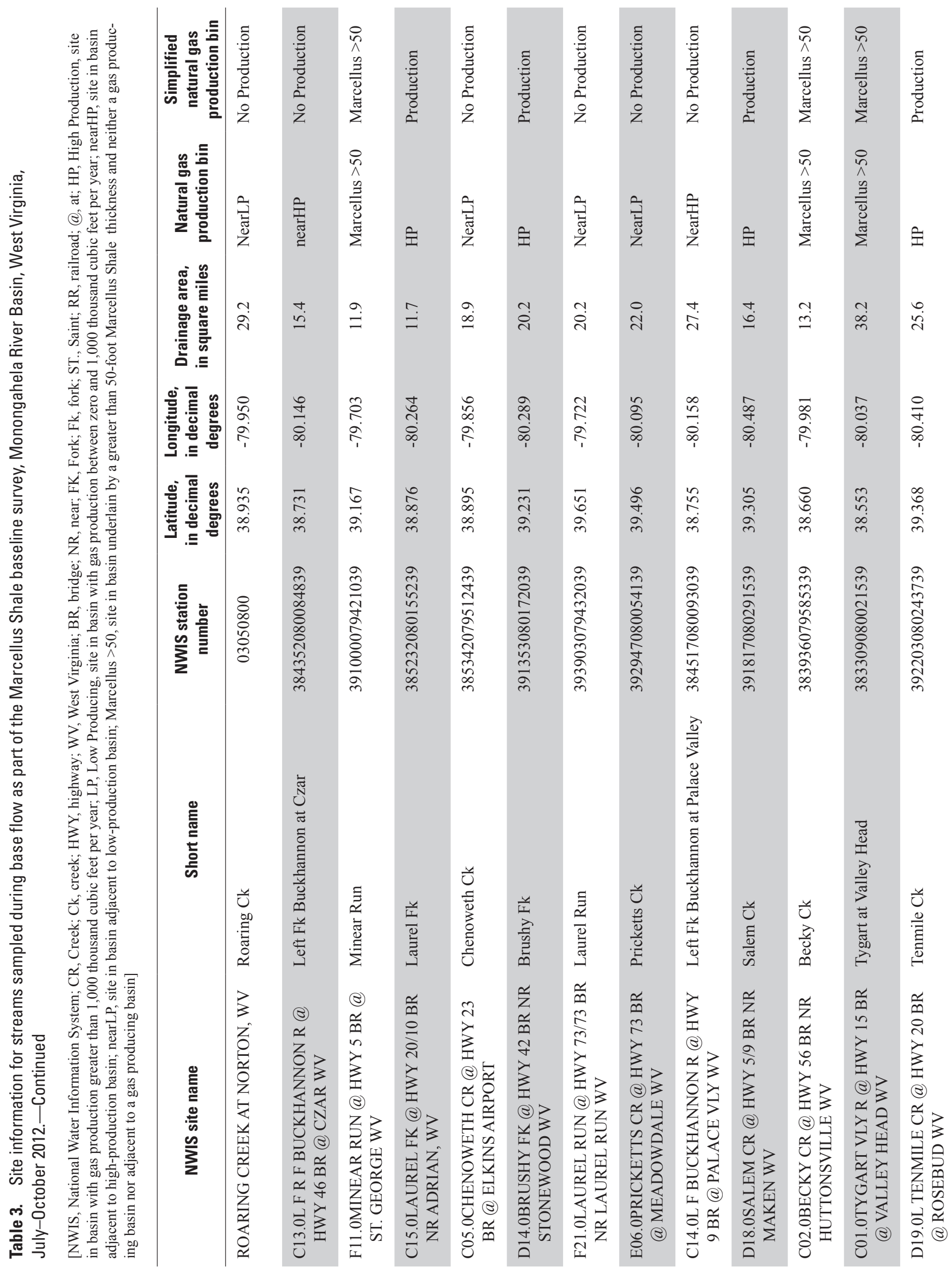




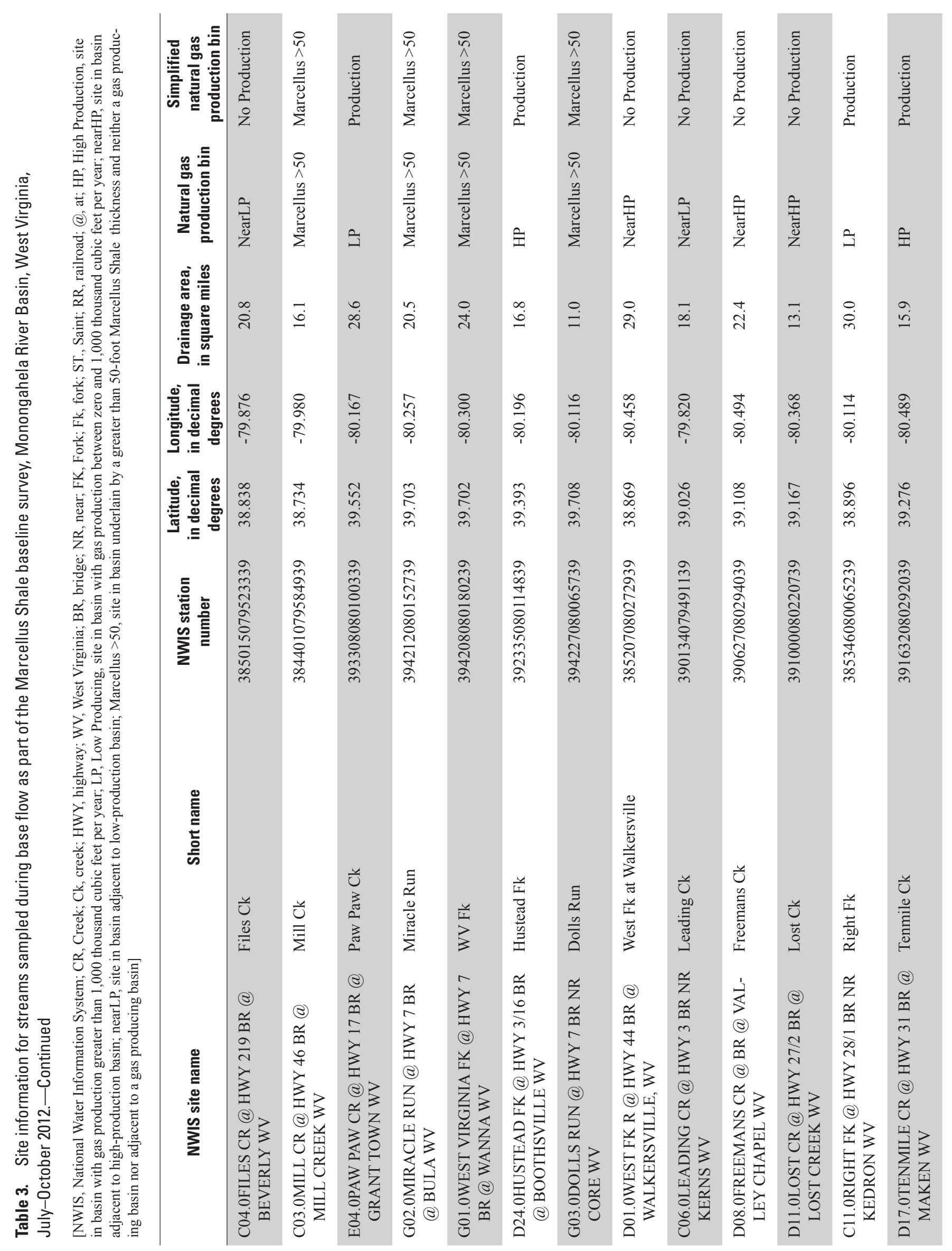




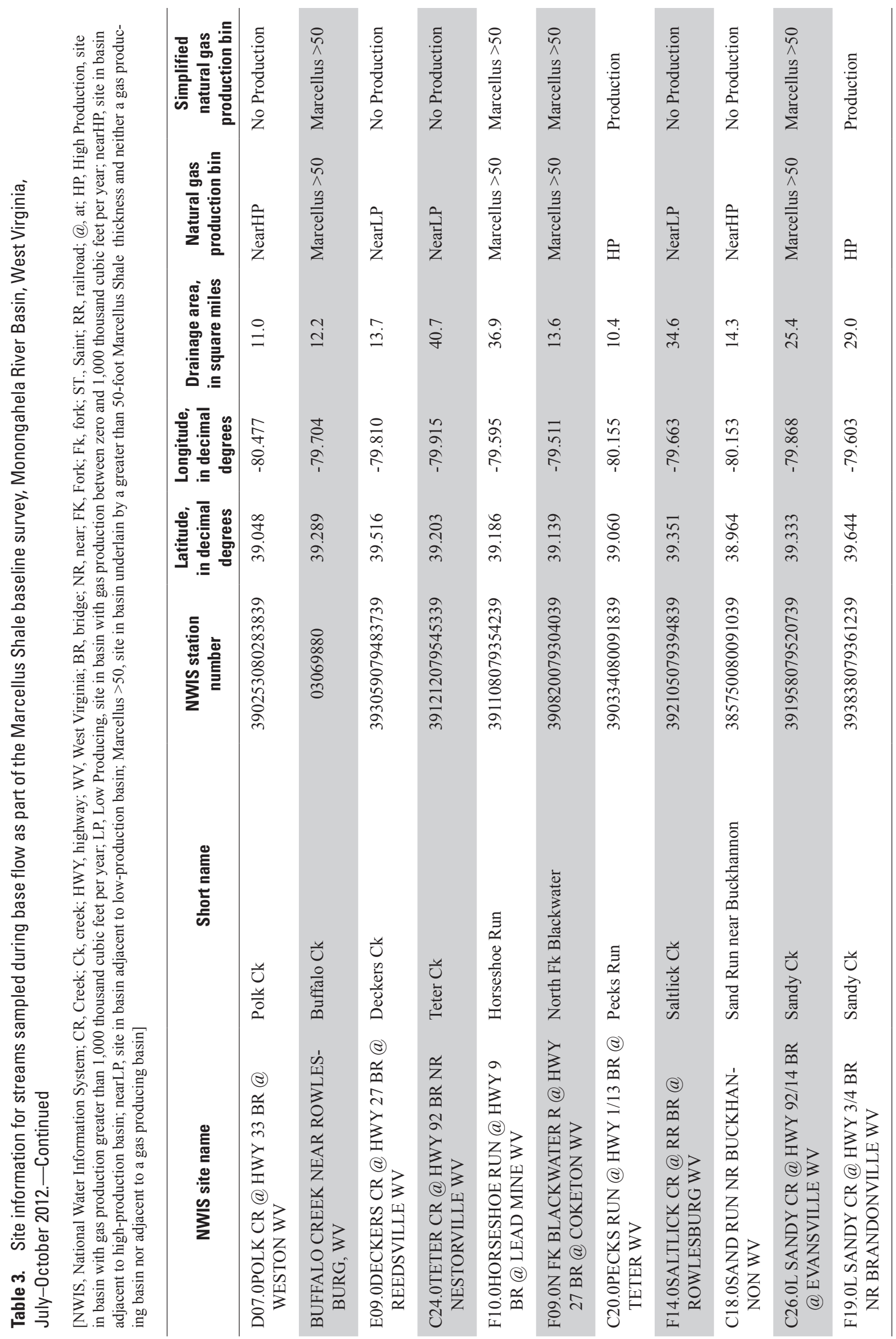


Appendixes 1-2 
Appendix 1. Data for groundwater samples collected as part of the Marcellus Shale baseline survey, Monongahela River Basin, West Virginia, June-September 2011.

$\left[<\right.$, less than; $\mathrm{mmHg}$, millimeters of mercury; $\mathrm{mg} / \mathrm{L}$, milligrams per liter; ${ }^{\circ} \mathrm{C}$, degrees Celsius; $\mu \mathrm{S} / \mathrm{cm}$, microsiemens per centimeter at $25^{\circ} \mathrm{C} ; \mu \mathrm{g} / \mathrm{L}$, micrograms per liter; wf, filtered water; ft bls, feet below land surface; NA, not applicable; $\mathrm{CaCO}_{3}$, calcium carbonate; --, no data; NA, not applicable; R, non-detect, result below sample-specific critical level; nd, not detected; \%o, per mil; pCi/L, picocuries per liter; ${ }^{13} \mathrm{C}$, carbon- $13,{ }^{18} \mathrm{O}$, oxygen-18; ${ }^{2} \mathrm{H}$, deuterium; ${ }^{34} \mathrm{~S}$, sulfur-34; $\mathrm{CH}_{4}$, methane; DIC, dissolved inorganic carbon; $\mathrm{H} 2 \mathrm{O}$, water; SO4, sulfate]

\begin{tabular}{|c|c|c|c|c|c|c|c|c|c|c|}
\hline $\begin{array}{l}\text { Local } \\
\text { well } \\
\text { name }\end{array}$ & $\begin{array}{l}\text { Sample } \\
\text { date }\end{array}$ & $\begin{array}{l}\text { Sample } \\
\text { start time }\end{array}$ & $\begin{array}{l}\text { Air pressure, } \\
\text { in } \mathrm{mmHg}\end{array}$ & $\begin{array}{l}\text { Dissolved } \\
\text { oxygen, } \\
\text { in } \mathrm{mg} / \mathrm{L}\end{array}$ & $\begin{array}{c}\text { Dissolved } \\
\text { oxygen, } \\
\text { in percent } \\
\text { saturation }\end{array}$ & $\begin{array}{c}\mathrm{pH}, \\
\text { in standard } \\
\text { units }\end{array}$ & $\begin{array}{c}\text { Specific } \\
\text { conductance, } \\
\text { in } \mu \mathrm{S} / \mathrm{cm}\end{array}$ & $\begin{array}{c}\text { Water } \\
\text { temperature, } \\
\text { in }{ }^{\circ} \mathrm{C}\end{array}$ & $\begin{array}{c}\text { Turbidity, } \\
\text { in formazin } \\
\text { nephelometric } \\
\text { units }\end{array}$ & $\begin{array}{l}\text { Depth } \\
\text { of well, } \\
\text { in ft bls }\end{array}$ \\
\hline Ran-0261 & $8 / 3 / 2011$ & 920 & 698 & 2.5 & 25 & 7.1 & 110 & 11.9 & 0.5 & NA \\
\hline Ran-0276 & $7 / 5 / 2011$ & 1330 & 695 & 0.3 & 3 & 9.4 & 794 & 13.4 & 0.5 & 320 \\
\hline Ran-0278 & $8 / 23 / 2011$ & 930 & 698 & 0.2 & 2 & 8.7 & 396 & 13.7 & 0.1 & 100 \\
\hline Ran-0277 & $7 / 6 / 2011$ & 1030 & 678 & 0.2 & 2 & 6.7 & 127 & 11.4 & 0.6 & 220 \\
\hline Ran-0280 & $7 / 6 / 2011$ & 1410 & 694 & 6.2 & 68 & 6.5 & 158 & 14.8 & 1.8 & 80 \\
\hline Ran-0282 & 7/7/2011 & 1430 & 706 & 0.9 & 9 & 6.7 & 201 & 12.6 & 0.2 & 105 \\
\hline Ups-0178 & 7/7/2011 & 1100 & 712 & 6.6 & 66 & 7.8 & 403 & 12.5 & 1 & 158 \\
\hline Ran-0284 & $8 / 22 / 2011$ & 1330 & 689 & 1.4 & 15 & 7 & 160 & 11.9 & 0.1 & 200 \\
\hline Ran-0259 & $8 / 2 / 2011$ & 1020 & 703 & 1.7 & 18 & 6.7 & 147 & 13.1 & 0.1 & 155 \\
\hline Ran-0260 & $8 / 10 / 2011$ & 940 & 694 & 0.1 & 1 & 8 & 407 & 11.7 & 1.6 & 222 \\
\hline Lew-0215 & $8 / 24 / 2011$ & 1010 & 729 & 1.7 & 17 & 7.5 & 327 & 14 & 0.8 & 100 \\
\hline Ran-0275 & $8 / 2 / 2011$ & 1410 & 714 & 1.2 & 13 & 6.7 & 235 & 15.5 & 0.2 & 500 \\
\hline Lew-0221 & $8 / 23 / 2011$ & 1445 & 733 & 0.2 & 3 & 7.4 & 485 & 13.8 & 0.4 & 100 \\
\hline Lew-0218 & 8/1/2011 & 1140 & 733 & 1.7 & 17 & 6.7 & 741 & 14.1 & 1.3 & 60 \\
\hline Ups-0177 & $8 / 3 / 2011$ & 1410 & 709 & 0.8 & 8 & 7.2 & 224 & 14.1 & 2 & 120 \\
\hline Tuc-0125 & $8 / 10 / 2011$ & 1400 & 673 & 4.3 & 44 & 7.8 & 295 & 10.6 & 0.1 & 250 \\
\hline Tuc-0124 & 8/9/2011 & 920 & 668 & 7.4 & 76 & 7.2 & 314 & 10.9 & 0.8 & 100 \\
\hline Tuc-0129 & 8/9/2011 & 1155 & 670 & 5.5 & 56 & 7.2 & 393 & 10.5 & 0.2 & 45 \\
\hline Har-0175 & $8 / 24 / 2011$ & 1405 & 729 & 1.9 & 20 & 7.9 & 548 & 14.8 & 0.4 & 45 \\
\hline Har-0170 & 8/1/2011 & 1700 & 735 & 0.2 & 2 & 7.3 & 410 & 15.5 & 0.3 & 75 \\
\hline Tuc-0127 & 8/8/2011 & 1420 & 712 & 1.2 & 12 & 8.2 & 192 & 13.6 & 0.1 & 60 \\
\hline Bar-0150 & $9 / 19 / 2011$ & 1220 & 728 & 2.2 & 23 & 6.7 & 380 & 15.7 & 36 & 52 \\
\hline Bar-0149 & $8 / 25 / 2011$ & 940 & 726 & 4.4 & 46 & 7.4 & 782 & 15.3 & 17 & 180 \\
\hline Bar-0151s & $9 / 21 / 2011$ & 1145 & 717 & 8.8 & 93 & 6 & 67 & 15.4 & 1.7 & NA \\
\hline Har-0173 & $7 / 28 / 2011$ & 945 & 734 & 0.5 & 5 & 8.2 & 680 & 14.7 & 0.4 & 70 \\
\hline Pre-0124 & $8 / 11 / 2011$ & 1020 & 710 & 0.3 & 3 & 7 & 349 & 15.5 & 0.5 & 205 \\
\hline Tay-0130 & $9 / 20 / 2011$ & 1300 & 729 & 1.4 & 14 & 6.7 & 226 & 13.6 & 1.2 & 160 \\
\hline Pre-0173 & $8 / 12 / 2011$ & 1000 & 717 & 1.3 & 13 & 7.9 & 174 & 13.3 & 0.2 & 57 \\
\hline Pre-0166 & $8 / 11 / 2011$ & 1500 & 696 & 0.6 & 6 & 6.8 & 146 & 12.8 & 0.4 & 100 \\
\hline Har-0177 & $9 / 19 / 2011$ & 1645 & 731 & 0.3 & 3 & 6.8 & 550 & 14.5 & 4.1 & 150 \\
\hline Tay-0129 & $7 / 27 / 2011$ & 1005 & 734 & 4.9 & 49 & 6 & 103 & 13.7 & 360 & 113 \\
\hline Pre-0164 & $8 / 30 / 2011$ & 1005 & 697 & 2.8 & 29 & 7 & 323 & 12.2 & 2.7 & 207 \\
\hline Pre-0177 & $8 / 29 / 2011$ & 1500 & 696 & 2.6 & 27 & 7.6 & 225 & 12.1 & 0.5 & 145 \\
\hline Pre-0176 & $6 / 30 / 2011$ & 1030 & 718 & 0.3 & 3 & 9.2 & 480 & 13.1 & 0.3 & 200 \\
\hline Mar-0300 & $7 / 26 / 2011$ & 1100 & 731 & 0.7 & 7 & 8 & 613 & 16.4 & 0.5 & 70 \\
\hline Mar-0296 & $7 / 25 / 2011$ & 1450 & 733 & 1.7 & 17 & 6.7 & 487 & 13.4 & 11 & 107 \\
\hline Pre-0162 & $6 / 29 / 2011$ & 1355 & 691 & 8.1 & 80 & 4.5 & 46 & 10.6 & 2.1 & 145 \\
\hline Pre-0163 & $6 / 29 / 2011$ & 1035 & 691 & 8.6 & 86 & 4.5 & 44 & 11 & 0.5 & 179 \\
\hline Pre-0172 & $8 / 30 / 2011$ & 1325 & 704 & 7.2 & 76 & 4.5 & 233 & 14.4 & 0.1 & 65 \\
\hline Pre-0178 & $8 / 31 / 2011$ & 1005 & 722 & 2.1 & 21 & 6.3 & 117 & 11.7 & 9.6 & NA \\
\hline Mng-0582 & $6 / 28 / 2011$ & 1355 & 703 & 7.1 & 77 & 6.6 & 200 & 15.6 & 0.9 & 190 \\
\hline
\end{tabular}


Appendix 1. Data for groundwater samples collected as part of the Marcellus Shale base-line survey, Monongahela River Basin, West Virginia, June-September 2011.—Continued

$\left[<\right.$, less than; $\mathrm{mmHg}$, millimeters of mercury; $\mathrm{mg} / \mathrm{L}$, milligrams per liter; ${ }^{\circ} \mathrm{C}$, degrees Celsius; $\mu \mathrm{S} / \mathrm{cm}$, microsiemens per centimeter at $25^{\circ} \mathrm{C} ; \mu \mathrm{g} / \mathrm{L}, \mathrm{micrograms}$ per liter; wf, filtered water; $\mathrm{ft}$ bls, feet below land surface; $\mathrm{NA}$, not applicable; $\mathrm{CaCO}_{3}$, calcium carbonate; --, no data; NA, not applicable; R, non-detect, result below sample-specific critical level; nd, not detected; \%o, per mil; pCi/L, picocuries per liter; ${ }^{13} \mathrm{C}$, carbon- $13,{ }^{18} \mathrm{O}$, oxygen-18; ${ }^{2} \mathrm{H}$, deuterium; ${ }^{34} \mathrm{~S}$, sulfur-34; $\mathrm{CH}_{4}$, methane; DIC, dissolved inorganic carbon; $\mathrm{H} 2 \mathrm{O}$, water; $\mathrm{SO} 4$, sulfate]

\begin{tabular}{|c|c|c|c|c|c|c|c|c|c|}
\hline $\begin{array}{l}\text { Local } \\
\text { well } \\
\text { name }\end{array}$ & $\begin{array}{c}\text { Total dissolved } \\
\text { solids, } \\
\text { dried at } 180^{\circ} \mathrm{C} \\
\text { in } \mathrm{mg} / \mathrm{L}\end{array}$ & $\begin{array}{c}\text { Hardness, } \\
\text { water, } \\
\text { in } \mathrm{mg} / \mathrm{L} \\
\text { as } \mathrm{CaCO}_{3}\end{array}$ & $\begin{array}{l}\text { Noncarbonate } \\
\text { hardness, wf, } \\
\text { in } \mathrm{mg} / \mathrm{L} \\
\text { as } \mathrm{CaCO}_{3}\end{array}$ & $\begin{array}{c}\text { Calcium, } \\
\text { wf, } \\
\text { in } \mathrm{mg} / \mathrm{L}\end{array}$ & $\begin{array}{c}\text { Magnesium, } \\
\text { wf, } \\
\text { in mg/L }\end{array}$ & $\begin{array}{c}\text { Potassium, } \\
\text { wf, } \\
\text { in mg/L }\end{array}$ & $\begin{array}{c}\text { Sodium, } \\
\text { wf, } \\
\text { in } \mathrm{mg} / \mathrm{L}\end{array}$ & $\begin{array}{c}\text { Alkalinity, } \\
\text { wf, inflection point, } \\
\text { laboratory titration, } \\
\text { in mg/L as } \mathrm{CaCO}_{3}\end{array}$ & $\begin{array}{c}\text { Alkalinity, } \\
\text { wf, inflection point, } \\
\text { field titration, } \\
\text { in } \mathrm{mg} / \mathrm{L} \text { as } \mathrm{CaCO}_{3}\end{array}$ \\
\hline Ran-0261 ${ }^{1}$ & 61 & 49.2 & 5 & 16.9 & 1.66 & 0.5 & 1.54 & -- & 44.1 \\
\hline Ran-0278 & 220 & 15.2 & -- & 4.5 & 0.903 & 1.2 & 77.3 & -- & 140 \\
\hline Ran-0277 & 75 & 48.2 & 0 & 12.5 & 4.05 & 1.53 & 3.58 & -- & 48.1 \\
\hline Ran-0280 & 103 & 43.2 & 8 & 14.7 & 1.57 & 0.79 & 13 & -- & 34.8 \\
\hline Ran-0282 & 98 & 35.5 & -- & 10.1 & 2.42 & 1.19 & 20.3 & -- & 54.6 \\
\hline Ran-0259 & 84 & 55.4 & 18 & 14.5 & 4.54 & 2.9 & 2.93 & -- & 37 \\
\hline Ran-0260 & 226 & 85.2 & -- & 26.2 & 4.56 & 2.26 & 48 & -- & 130 \\
\hline Lew-0215 & 183 & 98.7 & -- & 30.9 & 4.95 & 1.01 & 32.1 & -- & 138 \\
\hline Ran-0275 & 134 & 69.7 & 8 & 19 & 5.14 & 2.45 & 12 & -- & 61.9 \\
\hline Lew-0221 & 277 & 197 & -- & 60.7 & 10.7 & 1.74 & 23.5 & -- & 208 \\
\hline Lew-0218 & 522 & 307 & 148 & 91 & 19.1 & 1.59 & 32 & -- & 159 \\
\hline Ups-0177 & 115 & 41.8 & -- & 12.6 & 2.36 & 1.71 & 30.8 & -- & 81.9 \\
\hline Tuc-0127 & 130 & 45.4 & -- & 14.7 & 1.99 & 0.55 & 20.9 & -- & 68.3 \\
\hline Bar-0150 & 213 & 178 & -- & 55.3 & 9.49 & 1.17 & 9.41 & 158 & -- \\
\hline Bar-0149 & 493 & 141 & -- & 48.3 & 4.81 & 0.81 & 120 & 271 & -- \\
\hline Bar-0151s & 38 & 27 & -- & 8.6 & 1.33 & 0.68 & 0.46 & 21.6 & -- \\
\hline Har-0173 & 410 & 12.9 & -- & 3.81 & 0.684 & 0.92 & 162 & -- & 313 \\
\hline Pre-0124 & 200 & 123 & -- & 39.6 & 5.68 & 0.88 & 19.2 & 132 & -- \\
\hline Tay-0130 & 124 & 97.2 & -- & 28.4 & 6.27 & 1.65 & 7.3 & 108 & -- \\
\hline Pre-0173 & 101 & 47.4 & -- & 11.3 & 4.28 & 1.25 & 17.2 & 76.9 & -- \\
\hline Pre-0166 & 97 & 45.1 & -- & 11.6 & 3.9 & 1.34 & 8.15 & 43.8 & -- \\
\hline Har-0177 & 344 & 240 & -- & 74.8 & 12.8 & 1.56 & 28.9 & 235 & -- \\
\hline Tay-0129 & 54 & 30 & 2 & 7.04 & 3 & 0.99 & 0.91 & -- & 28.3 \\
\hline Pre-0164 & 200 & 129 & -- & 40.1 & 6.92 & 1.79 & 11 & 106 & -- \\
\hline Pre-0177 & 131 & 109 & -- & 39.7 & 2.29 & 0.64 & 1.71 & 105 & -- \\
\hline Pre-0176 & 282 & 3.5 & -- & 1.16 & 0.137 & 0.6 & 117 & -- & 254 \\
\hline
\end{tabular}


Appendix 1. Data for groundwater samples collected as part of the Marcellus Shale base-line survey, Monongahela River Basin, West Virginia, June-September 2011._Continued

$\left[<\right.$, less than; mmHg, millimeters of mercury; mg/L, milligrams per liter; ${ }^{\circ} \mathrm{C}$, degrees Celsius; $\mu \mathrm{S} / \mathrm{cm}$, microsiemens per centimeter at $25^{\circ} \mathrm{C} ; \mu \mathrm{g} / \mathrm{L}, \mathrm{micrograms}$ per liter; wf, filtered water; ft bls, feet below land surface; NA, not applicable; $\mathrm{CaCO}_{3}$, calcium carbonate; --, no data; NA, not applicable; R, non-detect, result below sample-specific critical level; nd, not detected; \%o, per mil; pCi/L, picocuries per liter; ${ }^{13} \mathrm{C}$, carbon- $13,{ }^{18} \mathrm{O}$, oxygen-18; ${ }^{2} \mathrm{H}$, deuterium; ${ }^{34} \mathrm{~S}$, sulfur-34; $\mathrm{CH}_{4}$, methane; DIC, dissolved inorganic carbon; $\mathrm{H} 2 \mathrm{O}$, water; SO4, sulfate]

\begin{tabular}{|c|c|c|c|c|c|c|c|c|c|}
\hline $\begin{array}{c}\text { Local } \\
\text { well } \\
\text { name }\end{array}$ & $\begin{array}{l}\text { Bicarbonate, } \\
\text { wf, inflection point, } \\
\text { field titration, } \\
\text { in } \mathrm{mg} / \mathrm{L}\end{array}$ & $\begin{array}{c}\text { Bromide, } \\
\text { wf, } \\
\text { in } \mathrm{mg} / \mathrm{L}\end{array}$ & $\begin{array}{c}\text { Carbon dioxide, } \\
\text { water, } \\
\text { in } \mathrm{mg} / \mathrm{L}\end{array}$ & $\begin{array}{c}\text { Carbonate, } \\
\text { wf, inflection point, } \\
\text { field titration } \\
\text { in } \mathrm{mg} / \mathrm{L}\end{array}$ & $\begin{array}{c}\text { Chloride, } \\
\text { wf, } \\
\text { in } \mathrm{mg} / \mathrm{L}\end{array}$ & $\begin{array}{c}\text { Fluoride, } \\
\text { wf, } \\
\text { in } \mathrm{mg} / \mathrm{L}\end{array}$ & $\begin{array}{c}\text { Silica, } \\
\text { wf, } \\
\text { in mg/L }\end{array}$ & $\begin{array}{c}\text { Sulfate, } \\
\text { wf, } \\
\text { in } \mathrm{mg} / \mathrm{L}\end{array}$ & $\begin{array}{c}\text { Aluminum, } \\
\text { wf, } \\
\text { in } \mu \mathrm{g} / \mathrm{L}\end{array}$ \\
\hline Ran- $0261^{1}$ & 53.7 & 0.015 & 6.9 & -- & 2.08 & $<.04$ & 3.17 & 5.13 & 4.2 \\
\hline Ran-0276 & 77.7 & 0.598 & 0.9 & 152 & 67.6 & 1.85 & 8.63 & 4.39 & 4.4 \\
\hline Ran-0278 & 170 & 0.384 & 0.6 & -- & 45.5 & 0.22 & 11.9 & $<.09$ & 1.7 \\
\hline Ran-0277 & 58.7 & 0.012 & 24.9 & -- & 1.32 & $<.04$ & 7.34 & 7.25 & $<1.7$ \\
\hline Ran-0280 & 42.4 & 0.015 & 28.2 & -- & 17 & $<.04$ & 3.48 & 6.66 & $<1.7$ \\
\hline Ran-0282 & 66.6 & 0.033 & 29.9 & -- & 20.5 & 0.1 & 7.31 & 0.25 & $<1.7$ \\
\hline Ups-0178 & 129 & 0.461 & 8.3 & -- & 48.4 & 0.42 & 7.81 & $<.09$ & $<1.7$ \\
\hline Ran-0284 & 85 & 0.015 & 15 & -- & 3.75 & 0.07 & 11.8 & 14.4 & $<1.7$ \\
\hline Ran-0259 & 45.1 & $<.010$ & 14 & -- & 1.49 & 0.1 & 7.03 & 11.6 & 2.1 \\
\hline Ran-0260 & 159 & 0.163 & 2.7 & -- & 40.8 & 0.18 & 9.83 & 9.63 & $<1.7$ \\
\hline Lew-0215 & 168 & 0.034 & 7.8 & -- & 8.44 & 0.24 & 13.4 & 12.7 & $<1.7$ \\
\hline Ran-0275 & 75.4 & 0.018 & 24 & -- & 20.9 & 0.09 & 6.93 & 22 & $<1.7$ \\
\hline Lew-0221 & 254 & 0.078 & 18 & -- & 27.1 & 0.16 & 14.2 & $<.09$ & $<1.7$ \\
\hline Lew-0218 & 194 & 0.035 & 58 & -- & 6.48 & 0.42 & 18.4 & 231 & $<1.7$ \\
\hline Ups-0177 & 99.8 & 0.119 & 10 & -- & 14.5 & 0.33 & 7.42 & $<.09$ & $<1.7$ \\
\hline Tuc-0125 & -- & 0.014 & 3.8 & -- & 3.21 & $<.04$ & 8.13 & 8.92 & 7.9 \\
\hline Tuc-0124 & 181 & 0.065 & 19 & -- & 3.16 & $<.04$ & 5.77 & 9.97 & 5.2 \\
\hline Tuc-0129 & 219 & 0.024 & 21 & -- & 12 & $<.04$ & 7.17 & 11.7 & $<1.7$ \\
\hline Har-0175 & -- & 0.027 & 7 & -- & 2.19 & 0.29 & 10.4 & 39.2 & $<1.7$ \\
\hline Har-0170 & 270 & 0.109 & 21 & -- & 10.9 & 0.2 & 14 & 13.3 & $<1.7$ \\
\hline Tuc-0127 & 83.3 & 0.081 & 0.9 & -- & 11 & 0.07 & 9.82 & 10.7 & 7.1 \\
\hline Bar-0150 & -- & 0.036 & 69 & -- & 10.4 & 0.12 & 13.4 & 23.4 & $<1.7$ \\
\hline Bar-0149 & -- & 0.112 & 23 & -- & 49.3 & 0.72 & 7.74 & 53.4 & 4 \\
\hline Bar-0151s & -- & $<.010$ & 42 & -- & 0.57 & $<.04$ & 8.48 & 7.6 & 10.4 \\
\hline Har-0173 & 382 & 0.107 & 4.1 & -- & 39.1 & 0.59 & 12.1 & 0.21 & $<1.7$ \\
\hline Pre-0124 & -- & 0.071 & 26 & -- & 21 & 0.05 & 18.1 & 6.1 & $<1.7$ \\
\hline Tay-0130 & -- & 0.033 & 38 & -- & 3.78 & 0.16 & 8.47 & 1.63 & $<1.7$ \\
\hline Pre-0173 & -- & 0.029 & 1.8 & -- & 5.83 & 0.07 & 12.1 & 0.46 & $<1.7$ \\
\hline Pre-0166 & -- & $<.010$ & 14 & -- & 7.03 & 0.05 & 14.7 & 13.2 & $<1.7$ \\
\hline Har-0177 & -- & 0.019 & 73 & -- & 1.86 & 0.14 & 11.1 & 59.8 & $<1.7$ \\
\hline Tay-0129 & 34.5 & 0.019 & 55 & -- & 1.05 & 0.09 & 8.41 & 10.9 & 2.5 \\
\hline Pre-0164 & -- & 0.019 & 18 & -- & 21.2 & 0.08 & 11.4 & 20.1 & $<1.7$ \\
\hline Pre-0177 & -- & $<.010$ & 5.5 & -- & 2.75 & $<.04$ & 3.31 & 6.21 & 1.8 \\
\hline Pre-0176 & 235 & 0.01 & 0.3 & 36.4 & 4.96 & 1.32 & 7.96 & 10.4 & 4.5 \\
\hline Mar-0300 & 364 & 0.156 & 5.8 & -- & 42.9 & 0.7 & 13.6 & $<.09$ & $<1.7$ \\
\hline Mar-0296 & 182 & 0.066 & 59 & -- & 12.2 & 0.12 & 8.99 & 83.6 & 5.7 \\
\hline Pre-0162 & 5.9 & $<.010$ & 53.6 & -- & 1.46 & $<.04$ & 3.63 & 13.5 & 979 \\
\hline Pre- 0163 & 2.3 & $<.010$ & 58.9 & -- & 0.94 & $<.04$ & 5.03 & 13 & 563 \\
\hline Pre- 0172 & -- & 0.021 & $<225$ & -- & 53.6 & 0.07 & 5.09 & 14.1 & 696 \\
\hline Pre-0178 & -- & 0.019 & 46 & -- & 3.24 & 0.11 & 7.6 & 0.76 & $<1.7$ \\
\hline Mng-0582 & 82.6 & $<.010$ & 32 & -- & -- & -- & 8.77 & -- & $<1.7$ \\
\hline
\end{tabular}


Appendix 1. Data for groundwater samples collected as part of the Marcellus Shale base-line survey, Monongahela River Basin, West Virginia, June-September 2011.-Continued

$\left[<\right.$, less than; $\mathrm{mmHg}$, millimeters of mercury; $\mathrm{mg} / \mathrm{L}$, milligrams per liter; ${ }^{\circ} \mathrm{C}$, degrees Celsius; $\mu \mathrm{S} / \mathrm{cm}$, microsiemens per centimeter at $25^{\circ} \mathrm{C} ; \mu \mathrm{g} / \mathrm{L}, \mathrm{micrograms}$ per liter; wf, filtered water; ft bls, feet below land surface; NA, not applicable; $\mathrm{CaCO}_{3}$, calcium carbonate; --, no data; NA, not applicable; R, non-detect, result below sample-specific critical level; nd, not detected; \%o, per mil; pCi/L, picocuries per liter; ${ }^{13} \mathrm{C}$, carbon- $13,{ }^{18} \mathrm{O}$, oxygen- $18 ;{ }^{2} \mathrm{H}$, deuterium; ${ }^{34} \mathrm{~S}$, sulfur-34; $\mathrm{CH}_{4}$, methane; DIC, dissolved inorganic carbon; $\mathrm{H} 2 \mathrm{O}$, water; $\mathrm{SO} 4$, sulfate]

\begin{tabular}{|c|c|c|c|c|c|c|c|c|c|}
\hline $\begin{array}{c}\text { Local } \\
\text { well } \\
\text { name }\end{array}$ & $\begin{array}{c}\text { Barium, } \\
\text { wf, } \\
\text { in } \mu \mathrm{g} / \mathrm{L}\end{array}$ & $\begin{array}{c}\text { Beryllium, } \\
\text { wf, } \\
\text { in } \mu g / L\end{array}$ & $\begin{array}{c}\text { Cadmium, } \\
\text { wf, } \\
\text { in } \mu \mathrm{g} / \mathrm{L}\end{array}$ & $\begin{array}{c}\text { Chromium, } \\
\text { wf, } \\
\text { in } \mu \mathrm{g} / \mathrm{L}\end{array}$ & $\begin{array}{c}\text { Cobalt, } \\
\text { wf, } \\
\text { in } \mu g / L\end{array}$ & $\begin{array}{c}\text { Copper, } \\
\text { wf, } \\
\text { in } \mu g / L\end{array}$ & $\begin{array}{c}\text { Iron, } \\
\text { wf, } \\
\text { in } \mu \mathrm{g} / \mathrm{L}\end{array}$ & $\begin{array}{c}\text { Lead, } \\
\text { wf, } \\
\text { in } \mu g / L\end{array}$ & $\begin{array}{c}\text { Manganese, } \\
\text { wf, } \\
\text { in } \mu \mathrm{g} / \mathrm{L}\end{array}$ \\
\hline Ran-0261 & 30.8 & $<.006$ & 0.032 & 0.11 & 0.051 & $<.50$ & $<3.2$ & $<.015$ & 0.23 \\
\hline Ran-0276 & 125 & 0.008 & $<.016$ & $<.06$ & $<.020$ & $<.50$ & $<3.2$ & $<.015$ & 3.52 \\
\hline Ran-0278 & 228 & $<.006$ & $<.016$ & $<.06$ & $<.020$ & $<.50$ & 46.1 & 0.015 & 11.6 \\
\hline Ran-0277 & 172 & 0.031 & $<.016$ & $<.06$ & 2.04 & $<.50$ & 3240 & $<.015$ & 279 \\
\hline Ran-0280 & 37.5 & $<.006$ & 0.026 & $<.06$ & 0.302 & 1.3 & 10.2 & 0.389 & 0.77 \\
\hline Ran-0282 & 267 & 0.037 & $<.016$ & $<.06$ & 0.091 & $<.50$ & 7910 & $<.015$ & 348 \\
\hline Ups-0178 & 439 & $<.006$ & $<.016$ & 0.26 & 0.113 & $<.50$ & 83 & 0.016 & 16.2 \\
\hline Ran-0284 & 292 & 0.022 & $<.016$ & $<.06$ & 0.027 & $<.50$ & 1690 & 0.023 & 621 \\
\hline Ran-0259 & 400 & 0.039 & $<.016$ & $<.06$ & 0.359 & $<.50$ & 3100 & 0.019 & 148 \\
\hline Ran-0260 & 563 & $<.006$ & $<.016$ & $<.06$ & 0.154 & $<.50$ & 31.6 & $<.015$ & 28 \\
\hline Lew-0215 & 618 & $<.006$ & $<.016$ & $<.06$ & 0.029 & $<.50$ & 84.4 & 0.026 & 141 \\
\hline Ran-0275 & 660 & 0.041 & $<.016$ & $<.06$ & 0.175 & $<.50$ & 5240 & $<.015$ & 356 \\
\hline Lew-0221 & 1250 & $<.006$ & $<.016$ & $<.06$ & 0.894 & $<.50$ & 666 & $<.015$ & 194 \\
\hline Lew-0218 & 62.4 & 0.027 & $<.016$ & $<.06$ & 1.36 & $<.50$ & 11600 & $<.015$ & 1670 \\
\hline Ups-0177 & 430 & 0.009 & $<.016$ & $<.06$ & 0.035 & $<.50$ & 890 & $<.015$ & 49.4 \\
\hline Tuc-0125 & 262 & $<.006$ & $<.016$ & 0.18 & 0.026 & $<.50$ & $<3.2$ & 0.043 & 1.26 \\
\hline Tuc-0124 & 44.6 & $<.006$ & 0.018 & 0.28 & 0.027 & 0.75 & $<3.2$ & 0.037 & $<.13$ \\
\hline Tuc-0129 & 207 & $<.006$ & $<.016$ & 0.2 & 0.049 & $<.50$ & $<3.2$ & 0.033 & $<.13$ \\
\hline Har-0175 & 238 & $<.006$ & $<.016$ & $<.06$ & 0.024 & $<.50$ & 905 & $<.015$ & 131 \\
\hline Har-0170 & 236 & $<.006$ & $<.016$ & $<.06$ & 0.024 & $<.50$ & 751 & $<.015$ & 145 \\
\hline Tuc-0127 & 514 & $<.006$ & $<.016$ & $<.06$ & 0.055 & $<.50$ & 10.9 & $<.015$ & 70.9 \\
\hline Bar-0150 & 346 & $<.006$ & $<.016$ & $<.06$ & 0.084 & $<.50$ & 1050 & $<.015$ & 420 \\
\hline Bar-0149 & 93.9 & $<.006$ & $<.016$ & 0.75 & 0.077 & $<.50$ & 8.4 & 0.099 & 12.2 \\
\hline Bar-0151s & 22.1 & 0.063 & 0.027 & 0.15 & 0.073 & $<.50$ & $<3.2$ & $<.015$ & 2.99 \\
\hline Har-0173 & 528 & 0.007 & $<.016$ & $<.06$ & 0.251 & $<.50$ & 27.7 & $<.015$ & 8.96 \\
\hline Pre-0124 & 645 & 0.01 & $<.016$ & $<.06$ & 0.058 & 0.54 & 1560 & 0.017 & 416 \\
\hline Tay-0130 & 392 & 0.03 & $<.016$ & $<.06$ & 0.267 & $<.50$ & 1940 & 0.036 & 185 \\
\hline Pre- 0173 & 1400 & $<.006$ & $<.016$ & $<.06$ & $<.020$ & $<.50$ & 64.4 & $<.015$ & 61 \\
\hline Pre- 0166 & 112 & 0.016 & $<.016$ & $<.06$ & 0.541 & $<.50$ & 1440 & $<.015$ & 149 \\
\hline Har-0177 & 192 & $<.006$ & $<.016$ & $<.06$ & 0.149 & $<.50$ & 775 & $<.015$ & 353 \\
\hline Tay-0129 & 81.7 & 0.016 & $<.016$ & 0.1 & 4.3 & $<.50$ & 7830 & $<.015$ & 290 \\
\hline Pre-0164 & 159 & $<.006$ & $<.016$ & $<.06$ & 0.469 & $<.50$ & 1360 & 0.04 & 256 \\
\hline Pre-0177 & 60.2 & $<.006$ & $<.016$ & 0.09 & 0.046 & $<.50$ & 3.7 & 0.016 & 0.14 \\
\hline Pre-0176 & 31.7 & $<.006$ & $<.016$ & $<.06$ & 0.153 & $<.50$ & $<3.2$ & $<.015$ & 2.57 \\
\hline Mar-0300 & 1350 & $<.006$ & $<.016$ & $<.06$ & 0.046 & $<.50$ & 84 & 0.016 & 32.6 \\
\hline Mar-0296 & 104 & 0.013 & $<.016$ & $<.06$ & 0.615 & $<.50$ & 574 & 0.017 & 184 \\
\hline Pre-0162 & 35.8 & 0.134 & 0.347 & 0.12 & 2.5 & 2.8 & 3.6 & 0.619 & 61.4 \\
\hline Pre- 0163 & 37.6 & 0.206 & 0.174 & 0.21 & 3.32 & 21.3 & 7.7 & 1.64 & 84.9 \\
\hline Pre- 0172 & 186 & 0.495 & 0.658 & 0.07 & 9.48 & 155 & 14.5 & 3.74 & 291 \\
\hline Pre-0178 & 206 & 0.017 & $<.016$ & $<.06$ & 1.34 & $<.50$ & 1920 & $<.015$ & 263 \\
\hline Mng-0582 & 53.9 & 0.007 & $<.016$ & 0.14 & 0.033 & 1.9 & 3.9 & 0.05 & 0.29 \\
\hline
\end{tabular}


Appendix 1. Data for groundwater samples collected as part of the Marcellus Shale base-line survey, Monongahela River Basin, West Virginia, June-September 2011.-Continued

$\left[<\right.$, less than; $\mathrm{mmHg}$, millimeters of mercury; $\mathrm{mg} / \mathrm{L}$, milligrams per liter; ${ }^{\circ} \mathrm{C}$, degrees Celsius; $\mu \mathrm{S} / \mathrm{cm}$, microsiemens per centimeter at $25^{\circ} \mathrm{C} ; \mu \mathrm{g} / \mathrm{L}$, micrograms per liter; wf, filtered water; $\mathrm{ft}$ bls, feet below land surface; NA, not applicable; $\mathrm{CaCO}_{3}$, calcium carbonate; --, no data; NA, not applicable; R, non-detect, result below sample-specific critical level; nd, not detected; \%o, per mil; pCi/L, picocuries per liter; ${ }^{13} \mathrm{C}$, carbon- $13,{ }^{18} \mathrm{O}$, oxygen-18; ${ }^{2} \mathrm{H}$, deuterium; ${ }^{34} \mathrm{~S}$, sulfur-34; $\mathrm{CH}_{4}$, methane; DIC, dissolved inorganic carbon; $\mathrm{H} 2 \mathrm{O}$, water; SO4, sulfate]

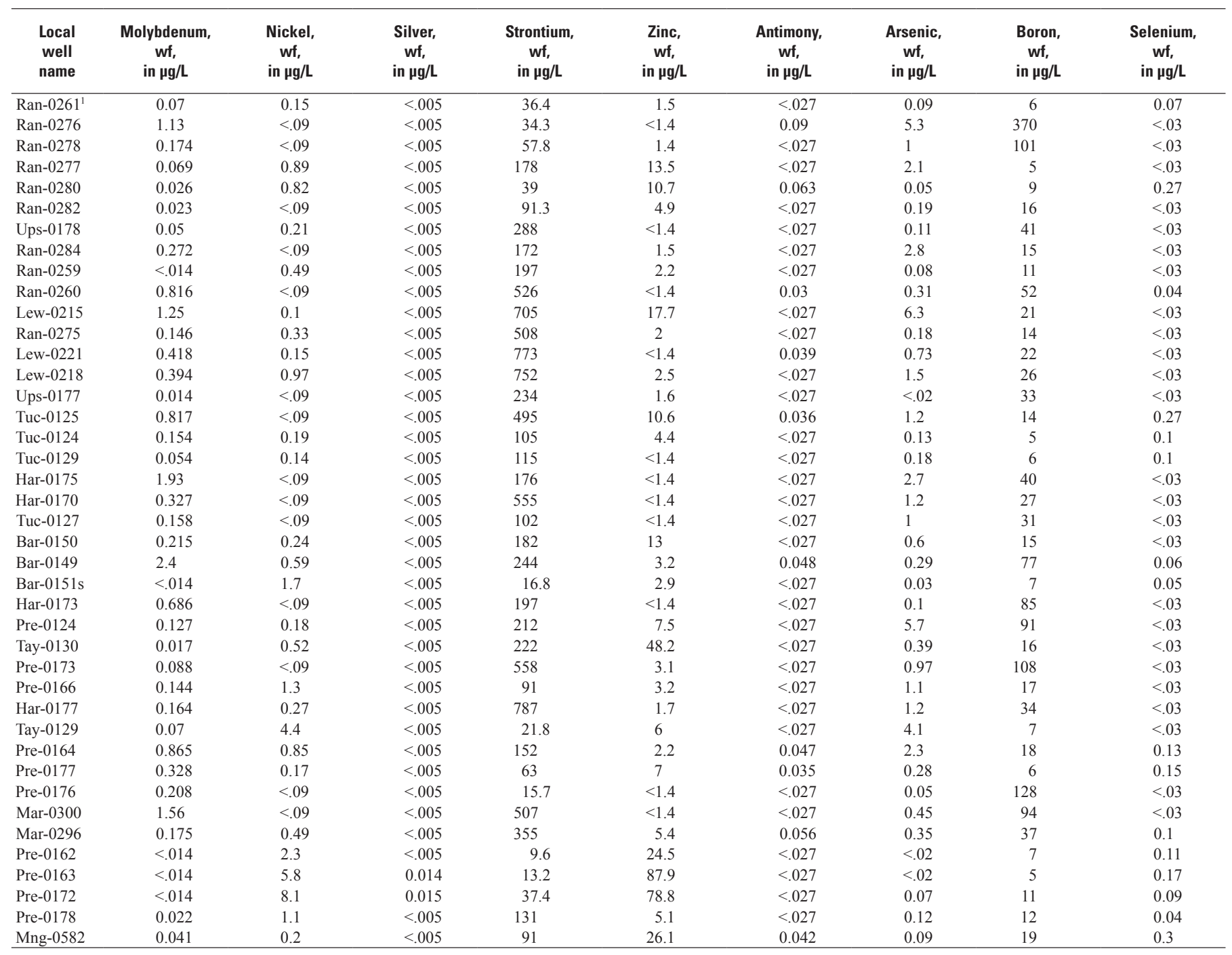


Appendix 1. Data for groundwater samples collected as part of the Marcellus Shale base-line survey, Monongahela River Basin, West Virginia, June-September 2011.-Continued

$\left[<\right.$, less than; mmHg, millimeters of mercury; $\mathrm{mg} / \mathrm{L}$, milligrams per liter; ${ }^{\circ} \mathrm{C}$, degrees Celsius; $\mu \mathrm{S} / \mathrm{cm}$, microsiemens per centimeter at $25^{\circ} \mathrm{C} ; \mu \mathrm{g} / \mathrm{L}, \mathrm{micrograms}$ per liter; wf, filtered water; ft bls, feet below land surface; NA, not applicable; $\mathrm{CaCO}_{3}$, calcium carbonate; --, no data; NA, not applicable; R, non-detect, result below sample-specific critical level; nd, not detected; \%o, per mil; pCi/L, picocuries per liter; ${ }^{13} \mathrm{C}$, carbon- $13,{ }^{18} \mathrm{O}$, oxygen- $18 ;{ }^{2} \mathrm{H}$, deuterium; ${ }^{34} \mathrm{~S}$, sulfur-34; $\mathrm{CH}_{4}$, methane; DIC, dissolved inorganic carbon; $\mathrm{H} 2 \mathrm{O}$, water; SO4, sulfate]

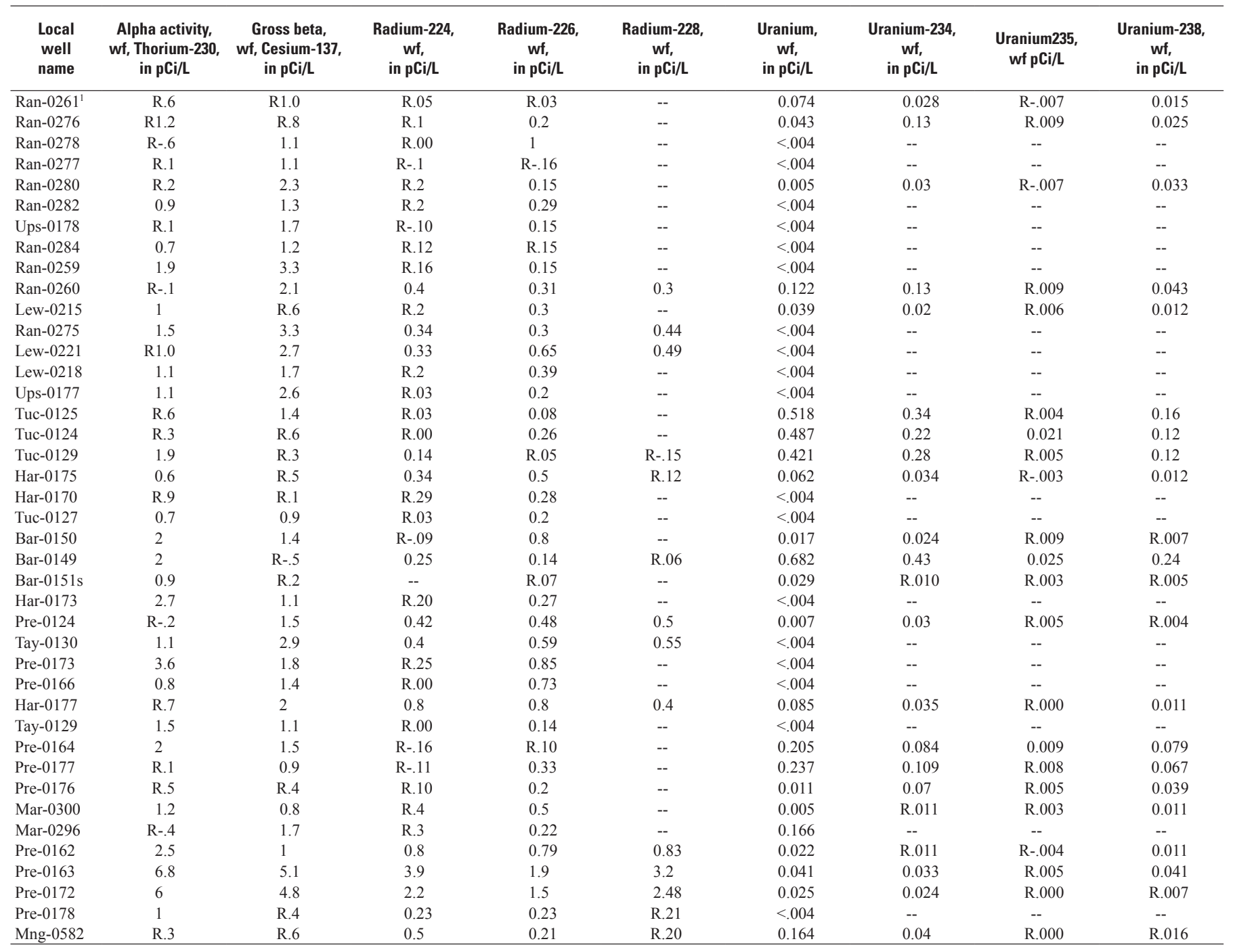


Appendix 1. Data for groundwater samples collected as part of the Marcellus Shale base-line survey, Monongahela River Basin, West Virginia, June-September 2011.-Continued

$\left[<\right.$, less than; $\mathrm{mmHg}$, millimeters of mercury; $\mathrm{mg} / \mathrm{L}$, milligrams per liter; ${ }^{\circ} \mathrm{C}$, degrees Celsius; $\mu \mathrm{S} / \mathrm{cm}$, microsiemens per centimeter at $25^{\circ} \mathrm{C} ; \mu \mathrm{g} / \mathrm{L}$, micrograms per liter; wf, filtered water; ft bls, feet below land surface; NA, not applicable; $\mathrm{CaCO}_{3}$, calcium carbonate; --, no data; NA, not applicable; R, non-detect, result below sample-specific critical level; nd, not detected; \%o, per mil; pCi/L, picocuries per liter; ${ }^{13} \mathrm{C}$, carbon- $13,{ }^{18} \mathrm{O}$, oxygen-18; ${ }^{2} \mathrm{H}$, deuterium; ${ }^{34} \mathrm{~S}$, sulfur-34; $\mathrm{CH}_{4}$, methane; DIC, dissolved inorganic carbon; $\mathrm{H} 2 \mathrm{O}$, water; SO4, sulfate]

\begin{tabular}{|c|c|c|c|c|c|c|c|c|c|}
\hline $\begin{array}{l}\text { Local } \\
\text { well } \\
\text { name }\end{array}$ & $\begin{array}{c}\text { Dissolved } \\
\text { methane, } \\
\text { in } \mathrm{mg} / \mathrm{L}\end{array}$ & $\begin{array}{l}\text { Dissolved } \\
\text { carbon } \\
\text { dioxide, } \\
\text { in } \mathrm{mg} / \mathrm{L}\end{array}$ & $\begin{array}{l}\text { Dissolved } \\
\text { nitrogen } \\
\text { gas }\left(\mathrm{N}_{2}\right) \text {, } \\
\text { in } \mathrm{mg} / \mathrm{L}\end{array}$ & $\begin{array}{c}\text { Dissolved oxygen, } \\
\text { in mg/L, laboratory } \\
\text { analysis }\end{array}$ & $\begin{array}{l}\text { Dissolved } \\
\text { argon, } \\
\text { in } \mathrm{mg} / \mathrm{L}\end{array}$ & $\begin{array}{l}{ }^{18} \mathbf{O}_{\text {s04 }} \\
\text { in } \% 0\end{array}$ & $\begin{array}{l}{ }^{34} \mathrm{~S}_{\mathrm{S}^{\prime}} \\
\text { in } \% 0\end{array}$ & $\begin{array}{l}{ }^{13} C_{D I C} \\
\text { in } \% 0\end{array}$ & $\begin{array}{l}{ }^{2} \mathbf{H}_{\mathrm{H} 20} \\
\text { in \%o }\end{array}$ \\
\hline Ran- $0261^{1}$ & 0.001 & 7.529 & 15.377 & 1.903 & 0.556 & 0.8 & 2.9 & -12.2 & -56.0 \\
\hline Ran-0276 & 48.204 & 0.742 & 9.585 & 0.104 & 0.457 & 1.8 & 5.6 & -7.9 & -60.1 \\
\hline Ran-0278 & 8.376 & 0.609 & 18.038 & 0.221 & 0.665 & -- & -- & -13.2 & -62.4 \\
\hline Ran-0277 & 0.04 & 23.735 & 19.453 & 0.246 & 0.696 & 1.6 & 4.0 & -15.0 & -67.8 \\
\hline Ran-0280 & 0.001 & 28.136 & 16.292 & 5.525 & 0.612 & -2.4 & 3.1 & -15.8 & -57.0 \\
\hline Ran-0282 & 2.353 & 29.516 & 19.412 & 0.246 & 0.701 & -- & -- & -16.1 & -59.5 \\
\hline Ups-0178 & 7.31 & 8.401 & 27.179 & 0.259 & 0.805 & -- & -- & -1.1 & -59.9 \\
\hline Ran-0284 & 0.01 & 10.892 & 19.535 & 0.25 & 0.672 & 3.0 & -17.1 & -17.3 & -65.1 \\
\hline Ran-0259 & 0.35 & 18.473 & 20.227 & 0.262 & 0.715 & nd & nd & -14.1 & -64.0 \\
\hline Ran-0260 & 0.963 & 3.469 & 19.141 & 0.236 & 0.662 & 1.3 & -1.8 & -13.6 & -62.6 \\
\hline Lew-0215 & 0.001 & 7.584 & 20.899 & 0.266 & 0.717 & 2.3 & -7.5 & -18.5 & -53.3 \\
\hline Ran-0275 & 0.143 & 19.434 & 18.668 & 0.248 & 0.657 & 3.1 & 1.5 & -14.5 & -60.3 \\
\hline Lew-0221 & 21.916 & 15.707 & 10.688 & 0.114 & 0.419 & -3.3 & 8.9 & -20.0 & -51.1 \\
\hline Lew-0218 & 0.079 & 47.99 & 20.701 & 0.252 & 0.727 & 0.3 & 5.4 & -17.5 & -52.1 \\
\hline Ups-0177 & 12.839 & 8.911 & 17.689 & 0.202 & 0.676 & -- & -- & -7.5 & -61.0 \\
\hline Tuc-0125 & 0.001 & 5.836 & 18.768 & 1.349 & 0.677 & 0.7 & 3.5 & -12.1 & -63.2 \\
\hline Tuc-0124 & 0.001 & 22.685 & 20.825 & 2.172 & 0.719 & 0.1 & -3.4 & -12.8 & -61.6 \\
\hline Tuc-0129 & 0.001 & 21.023 & 18.845 & 1.482 & 0.683 & 0.4 & 1.3 & -13.2 & -62.3 \\
\hline Har-0175 & 0.009 & 6.821 & 20.748 & 0.273 & 0.722 & 3.8 & -4.9 & -19.2 & -53.0 \\
\hline Har-0170 & 2.112 & 13.589 & 20.214 & 0.249 & 0.708 & 10.9 & 14.6 & -20.9 & -52.0 \\
\hline Tuc-0127 & 0.325 & 0.787 & 18.712 & 0.249 & 0.665 & 1.3 & -4.6 & -18.4 & -60.6 \\
\hline Bar-0150 & 0.001 & 49.47 & 21.16 & 0.223 & 0.671 & 3.2 & -6.2 & -16.8 & -55.1 \\
\hline Bar-0149 & 0.406 & 17.225 & 17.411 & 0.228 & 0.632 & 5.4 & 4.5 & -18.7 & -51.1 \\
\hline Bar-0151s & 0.001 & 48.887 & 15.511 & 6.095 & 0.588 & -0.4 & -0.4 & -19.8 & -59.9 \\
\hline Har-0173 & 12.264 & 3.595 & 18.173 & 0.212 & 0.657 & -- & -- & -12.7 & -51.7 \\
\hline Pre-0124 & 1.629 & 28.386 & 21.642 & 0.257 & 0.736 & 3.5 & -3.9 & -16.8 & -60.7 \\
\hline Tay-0130 & 3.069 & 32.457 & 19.205 & 0.242 & 0.682 & 3.6 & 17.1 & -9.8 & -59.5 \\
\hline Pre-0173 & 3.159 & 2.137 & 18.348 & 0.237 & 0.662 & -- & -- & -15.0 & -60.5 \\
\hline Pre-0166 & 0.003 & 15.067 & 20.132 & 0.252 & 0.688 & 1.2 & -7.4 & -16.8 & -66.6 \\
\hline Har-0177 & 0.001 & 60.142 & 19.833 & 0.554 & 0.729 & -3.2 & -1.1 & -12.2 & -50.0 \\
\hline Tay-0129 & 0.001 & 68.831 & 18.331 & 1.196 & 0.679 & 3.8 & 0.7 & -17.3 & -57.0 \\
\hline Pre-0164 & 0.001 & 20.281 & 19.623 & 0.233 & 0.656 & -0.4 & -7.0 & -13.2 & -62.5 \\
\hline Pre-0177 & 0.001 & 5.825 & 15.327 & 0.214 & 0.561 & 2.4 & -2.5 & -12.6 & -59.8 \\
\hline Pre-0176 & 0.381 & 0.327 & 22.274 & 0.28 & 0.762 & -0.3 & 3.8 & -13.0 & -58.5 \\
\hline Mar-0300 & 17.839 & 4.715 & 14.968 & 0.15 & 0.526 & -- & -- & -19.5 & -52.5 \\
\hline Mar-0296 & 0.001 & 47.655 & 19.568 & 0.245 & 0.679 & 7.8 & 8.1 & -15.9 & -51.1 \\
\hline Pre-0162 & 0.001 & 53.295 & 18.524 & 8.204 & 0.687 & -0.8 & 1.5 & -23.4 & -63.5 \\
\hline Pre- 0163 & 0.001 & 58.565 & 17.185 & 8.071 & 0.66 & -- & -- & -22.9 & -66.3 \\
\hline Pre-0172 & 0.001 & 64.834 & 17.199 & 5.76 & 0.648 & 1.4 & 1.8 & -23.4 & -61.9 \\
\hline Pre-0178 & 0.387 & 43.301 & 21.802 & 0.273 & 0.783 & -- & -- & -18.1 & -57.8 \\
\hline Mng-0582 & 0.001 & 31.883 & 17.32 & 3.047 & 0.65 & 0.8 & 2.8 & -16.2 & -63.5 \\
\hline
\end{tabular}


Appendix 1. Data for groundwater samples collected as part of the Marcellus Shale base-line survey, Monongahela River Basin, West Virginia, June-September 2011.-Continued

$\left[<\right.$, less than; $\mathrm{mmHg}$, millimeters of mercury; $\mathrm{mg} / \mathrm{L}$, milligrams per liter; ${ }^{\circ} \mathrm{C}$, degrees Celsius; $\mu \mathrm{S} / \mathrm{cm}$, microsiemens per centimeter at $25^{\circ} \mathrm{C} ; \mu \mathrm{g} / \mathrm{L}, \mathrm{micrograms}$ per liter; wf, filtered water; ft bls, feet below land surface; NA, not applicable; $\mathrm{CaCO}_{3}$, calcium carbonate; --, no data; NA, not applicable; R, non-detect, result below sample-specific critical level; nd, not detected; \%o, per mil; pCi/L, picocuries per liter; ${ }^{13} \mathrm{C}$, carbon- $13,{ }^{18} \mathrm{O}$, oxygen- $18 ;{ }^{2} \mathrm{H}$, deuterium; ${ }^{34} \mathrm{~S}$, sulfur-34; $\mathrm{CH}_{4}$, methane; DIC, dissolved inorganic carbon; $\mathrm{H} 2 \mathrm{O}$, water; $\mathrm{SO} 4$, sulfate]

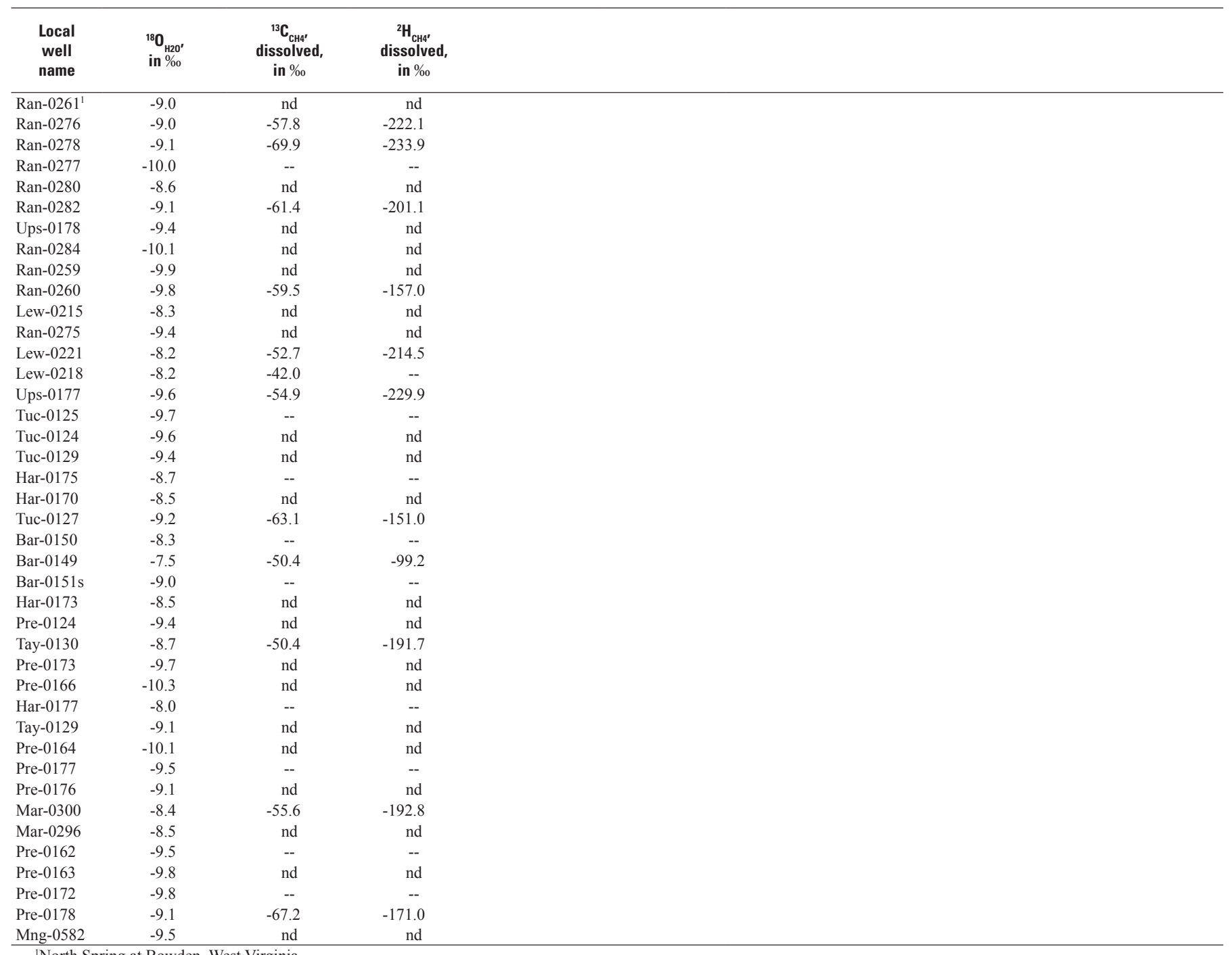

${ }^{1}$ North Spring at Bowden, West Virginia. 
Appendix 2. Data for base-flow samples collected as part of the Marcellus Shale base-line survey, Monongahela River Basin, West Virginia, July-October 2012.

[CR, Creek; Ck, creek; HWY, highway; WV, West Virginia; BR, bridge; NR, near; FK, Fork; Fk, fork; ST., Saint; RR, railroad; <, less than; mmHg, millimeters of mercury; mg/L, milligrams per liter; $\mathrm{ft} / \mathrm{s}$, cubic feet per second; ${ }^{\circ} \mathrm{C}$, degrees Celsius; $\mu \mathrm{S} / \mathrm{cm}$, microsiemens per centimeter at $25^{\circ} \mathrm{C} ; \mu \mathrm{g} / \mathrm{L}$, micrograms per liter; wf, filtered water; $\mathrm{cm}$, centimeter; $\mathrm{CaCO}_{3}$, calcium carbonate; --, no data; $\mathrm{R}$, non-detect, result below sample-specific critical level; $\%$, per mil; pCi/L, picocuries per liter; ${ }^{13} \mathrm{C}$, carbon- $13,{ }^{18} \mathrm{O}$, oxygen- $18 ;{ }^{2} \mathrm{H}$, deuterium; ${ }^{34} \mathrm{~S}$, sulfur- $34 ; \mathrm{CH}_{4}$, methane; DIC, dissolved inorganic carbon; $\mathrm{H} 2 \mathrm{O}$, water; $\mathrm{SO} 4$, sulfate]

\begin{tabular}{|c|c|c|c|c|c|c|}
\hline Station number & Station name & $\begin{array}{l}\text { Sample } \\
\text { date }\end{array}$ & $\begin{array}{l}\text { Sample } \\
\text { start time }\end{array}$ & $\begin{array}{l}\text { Air pressure, } \\
\text { in } \mathrm{mmHg}\end{array}$ & $\begin{array}{c}\text { Discharge, } \\
\text { instantaneous, } \\
\text { in } \mathrm{ft}^{3} / \mathrm{s}\end{array}$ & $\begin{array}{c}\text { Dissolved } \\
\text { oxygen, } \\
\text { in mg/L }\end{array}$ \\
\hline 03050800 & ROARING CREEK AT NORTON, WV & $8 / 27 / 2012$ & 1330 & 718 & 2.3 & 8.8 \\
\hline 03062215 & INDIAN CREEK AT CROWN, WV & $8 / 21 / 2012$ & 1240 & 738 & 6.2 & 11.3 \\
\hline 03069880 & BUFFALO CREEK NEAR ROWLESBURG, WV & $10 / 16 / 2012$ & 935 & 716 & 4.9 & 10.5 \\
\hline 383309080021539 & C01.0TYGARTVLY R@HWY15 BR@VALLEY HEAD WV & $8 / 29 / 2012$ & 940 & 701 & 1.6 & 8.9 \\
\hline 383936079585339 & C02.0BECKY CR@HWY 56 BR NR HUTTONSVILLE WV & $8 / 29 / 2012$ & 1220 & 706 & 0.55 & 8.4 \\
\hline 384352080084839 & C13.0L F R F BUCKHANNON R @ HWY46 BR @ CZAR WV & $8 / 28 / 2012$ & 1510 & 706 & 1.2 & 8.4 \\
\hline 384401079584939 & C03.0MILL CR@HWY46 BR@MILL CREEK WV & $8 / 29 / 2012$ & 1415 & 709 & 0.57 & 7.9 \\
\hline 384440080140939 & C12.0R F BUCKHANNON R@HWY48BR@NEWLONTON.WV & $8 / 28 / 2012$ & 1000 & 713 & 2.3 & 8.6 \\
\hline 384517080093039 & C14.0L F BUCKHANNON R@HWY 9 BR @ PALACE VLY WV & $8 / 30 / 2012$ & 1050 & 711 & 1.2 & 9 \\
\hline 385015079523339 & C04.0FILES CR@HWY219 BR@BEVERLYWV & $8 / 28 / 2012$ & 835 & 711 & 0.8 & 7.3 \\
\hline 385207080272939 & D01.0WEST FK R @ HWY 44 BR @ WALKERSVILLE, WV & $8 / 29 / 2012$ & 1340 & 734 & 0.47 & 4.6 \\
\hline 385232080155239 & C15.0LAUREL FK@HWY 20/10 BR NR ADRIAN, WV & $8 / 23 / 2012$ & 1035 & 727 & 0.64 & 9.1 \\
\hline 385307080175339 & C16.0FRENCH CR@HWY20 BR @ FRENCH CREEK WV & $8 / 23 / 2012$ & 915 & 727 & 1.2 & 5.6 \\
\hline 385333079384039 & F03.0GLADY FK@HWY33 BR @ ALPENA WV & $8 / 28 / 2012$ & 1110 & 695 & 6.4 & 8.3 \\
\hline 385342079512439 & C05.0CHENOWETH CR@HWY23 BR@ELKINS AIRPORT & $8 / 27 / 2012$ & 1715 & 712 & 1 & 7.6 \\
\hline 385346080065239 & C11.0RIGHT FK@ HWY 28/1 BR NR KEDRON WV & $8 / 29 / 2012$ & 1710 & 713 & 0.34 & 7.5 \\
\hline 385750080091039 & C18.0SAND RUN NR BUCKHANNON WV & $8 / 27 / 2012$ & 1350 & 724 & 3.1 & 8.8 \\
\hline 390134079491139 & C06.0LEADING CR @ HWY 3 BR NR KERNS WV & $8 / 28 / 2012$ & 1400 & 712 & 0.27 & 7.4 \\
\hline 390253080283839 & D07.0POLK CR@HWY33 BR@WESTONwV & $8 / 29 / 2012$ & 915 & 736 & 0.05 & 7.9 \\
\hline 390334080091839 & C20.0PECKS RUN@HWY 1/13 BR@TETER WV & $10 / 16 / 2012$ & 1415 & 719 & 0.95 & 10.4 \\
\hline 390520080232239 & D10.0HACKERS CR@HWY 14 BR NR JANE LEW WV & $8 / 22 / 2012$ & 1520 & 739 & 5.2 & 13.6 \\
\hline 390627080294039 & D08.0FREEMANS CR @BR @ VALLEY CHAPEL WV & $8 / 22 / 2012$ & 1330 & 739 & 0.27 & 8.6 \\
\hline 390820079304039 & F09.0N FK BLACKWATER R @ HWY27 BR @ COKETON WV & $10 / 15 / 2012$ & 1320 & 680 & 15 & 10.1 \\
\hline 390853079424839 & F12.0CLOVER RUN@HWY21 BR @ST. GEORGEWV & $8 / 30 / 2012$ & 1105 & 726 & -- & 9.1 \\
\hline 390947080154239 & D12.0GNATTY CR@HWY 20/20 BR @ ROMINES MILLS WV & $8 / 23 / 2012$ & 1345 & 740 & 9.9 & 8.7 \\
\hline 391000079421039 & F11.0MINEAR RUN@HWY 5 BR @ ST. GEORGE WV & $8 / 30 / 2012$ & 835 & 723 & 0.85 & 8.7 \\
\hline 391000080220739 & D11.0LOST CR@HWY 27/2 BR @ LOST CREEK WV & $8 / 22 / 2012$ & 940 & 739 & 0.15 & 6 \\
\hline 391023080140539 & D13.0ELK CR@HWY 57/2 BR NR ROMINES MILLS WV & $8 / 23 / 2012$ & 1045 & 739 & 9.2 & 8.7 \\
\hline 391108079354239 & F10.0HORSESHOE RUN@HWY9 BR @LEAD MINEWV & $10 / 15 / 2012$ & 1530 & 709 & 7.6 & 10 \\
\hline 391212079545339 & C24.0TETER CR @ HWY 92 BR NR NESTORVILLE WV & $10 / 10 / 2012$ & 1000 & 726 & 15 & 11 \\
\hline 391353080172039 & D14.0BRUSHY FK @ HWY 42 BR NR STONEWOOD WV & $8 / 20 / 2012$ & 1305 & 733 & 1.1 & 8.7 \\
\hline 391605080094739 & D15.0SIMPSON CR@HWY 13/13 BR@ROSEMONT WV & $8 / 20 / 2012$ & 1555 & 733 & 10 & 8.6 \\
\hline 391632080292039 & D17.0TENMILE CR@HWY31 BR@MAKEN WV & $8 / 22 / 2012$ & 1045 & 739 & 0.17 & 4.9 \\
\hline 391817080291539 & D18.0SALEM CR@ HWY 5/9 BR NR MAKEN WV & $8 / 20 / 2012$ & 1355 & 733 & 0.73 & 8.8 \\
\hline 391958079520739 & C26.0L SANDY CR@HWY 92/14 BR@EVANSVILLE WV & $10 / 11 / 2012$ & 1310 & 731 & 4.4 & 10.2 \\
\hline 392105079394839 & F14.0SALTLICK CR@RR BR@ROWLESBURG WV & $10 / 16 / 2012$ & 1015 & 723 & 5 & 10.4 \\
\hline 392203080243739 & D19.0L TENMILE CR@HWY 20 BR @ ROSEBUD WV & $8 / 22 / 2012$ & 1400 & 740 & 0.99 & 9.4 \\
\hline 392335080114839 & D24.0HUSTEAD FK@HWY3/16 BR@BOOTHSVILLE WV & $8 / 1 / 2012$ & 1320 & 734 & 0.38 & 9.9 \\
\hline 392457080192939 & D21.0BINGAMON CR@HWY 8 BR@PINE BLUFF WV & $8 / 1 / 2012$ & 1510 & 734 & 4.2 & 10.1 \\
\hline 392947080054139 & E06.0PRICKETTS CR@HWY73 BR@MEADOWDALE WV & $7 / 31 / 2012$ & 1650 & 734 & 1 & 9.2 \\
\hline 393059079483739 & E09.0DECKERS CR@HWY 27 BR @ REEDSVILLE WV & $10 / 10 / 2012$ & 1435 & 714 & 3.5 & 10.3 \\
\hline 393250080023439 & E08.0WHITEDAY CR @ HWY 36 BR NR SMITHTOWN WV & $7 / 31 / 2012$ & 1650 & 734 & 3.7 & 9 \\
\hline 393308080100339 & E04.0PAW PAW CR@HWY17 BR@GRANT TOWN WV & $8 / 21 / 2012$ & 1005 & 738 & 0.92 & 5.9 \\
\hline 393320080212239 & E02.0PYLES FK@HWY 250/5 BR NR METZ WV & $8 / 1 / 2012$ & 930 & 733 & 2 & 6 \\
\hline 393408080045039 & E07.0INDIAN CR@HWY 45/2 BR@OSGOOD WV & $8 / 21 / 2012$ & 1505 & 738 & 9.1 & 9.4 \\
\hline 393838079361239 & F19.0L SANDY CR@HWY 3/4 BR NR BRANDONVILLE WV & $10 / 9 / 2012$ & 1245 & 719 & 12 & 11 \\
\hline 393903079432039 & F21.0LAUREL RUN@ HWY 73/73 BR NR LAUREL RUN WV & $7 / 31 / 2012$ & 1310 & 721 & 0.98 & 9.3 \\
\hline 394208080180239 & G01.0WEST VIRGINIA FK @ HWY 7 BR @ WANNA WV & $8 / 21 / 2012$ & 930 & 737 & 0.54 & 4.8 \\
\hline 394212080152739 & G02.0MIRACLERUN@HWY7 BR @BULAwV & $8 / 21 / 2012$ & 1235 & 737 & 0.48 & 8.1 \\
\hline 394227080065739 & G03.0DOLLS RUN@ @ HWY 7 BR NR CORE WV & $8 / 21 / 2012$ & 1540 & 738 & 0.2 & 9.5 \\
\hline
\end{tabular}


Appendix 2. Data for base-flow samples collected as part of the Marcellus Shale base-line survey, Monongahela River Basin, West Virginia, July-October 2012.-Continued

[CR, Creek; Ck, creek; HWY, highway; WV, West Virginia; BR, bridge; NR, near; FK, Fork; Fk, fork; ST., Saint; RR, railroad; <, less than; mmHg, millimeters of mercury; $\mathrm{mg} / \mathrm{L}$, milligrams per liter; $\mathrm{ft}^{3} / \mathrm{s}$, cubic feet per second; ${ }^{\circ} \mathrm{C}$, degrees Celsius; $\mu \mathrm{S} / \mathrm{cm}$, microsiemens per centimeter at $25^{\circ} \mathrm{C} ; \mu \mathrm{g} / \mathrm{L}$, micrograms per liter; wf, filtered water; $\mathrm{cm}$, centimeter; $\mathrm{CaCO}_{3}$, calcium carbonate; --, no data; $\mathrm{R}$, non-detect, result below sample-specific critical level; $\%$, per mil; pCi/L, picocuries per liter; ${ }^{13} \mathrm{C}$, carbon- $13,{ }^{18} \mathrm{O}$, oxygen- $18 ;{ }^{2} \mathrm{H}$, deuterium; ${ }^{34} \mathrm{~S}$, sulfur- $34 ; \mathrm{CH}_{4}$, methane; DIC, dissolved inorganic carbon; $\mathrm{H} 2 \mathrm{O}$, water; $\mathrm{SO} 4$, sulfate]

\begin{tabular}{|c|c|c|c|c|c|c|c|c|c|}
\hline Station number & $\begin{array}{l}\text { Dissolved } \\
\text { oxygen, } \\
\text { in percent } \\
\text { saturation }\end{array}$ & $\begin{array}{c}\mathrm{pH}, \\
\text { in standard units }\end{array}$ & $\begin{array}{c}\text { Specific } \\
\text { conductance, } \\
\text { in } \mu \mathrm{S} / \mathrm{cm}\end{array}$ & $\begin{array}{c}\text { Water } \\
\text { temperature, } \\
\text { in }{ }^{\circ} \mathrm{C}\end{array}$ & $\begin{array}{c}\text { Turbidity, } \\
\text { in formazin } \\
\text { nephelometric } \\
\text { units }\end{array}$ & $\begin{array}{c}\text { Total dissolved } \\
\text { solids, } \\
\text { dried at } 180^{\circ} \mathrm{C} \text {, } \\
\text { in } \mathrm{mg} / \mathrm{L}\end{array}$ & $\begin{array}{l}\text { Hardness, water, } \\
\text { in } \mathrm{mg} / \mathrm{L} \text { as } \mathrm{CaCO}_{3}\end{array}$ & $\begin{array}{c}\text { Noncarbonate } \\
\text { hardness, wf, } \\
\text { in } \mathrm{mg} / \mathrm{L} \text { as } \mathrm{CaCO}_{3}\end{array}$ & $\begin{array}{c}\text { Calcium, } \\
\text { wf, } \\
\text { in } \mathrm{mg} / \mathrm{L}\end{array}$ \\
\hline 03050800 & 101 & 5.4 & 274 & 19.2 & 0 & 168 & 112 & 112 & 28.3 \\
\hline 03062215 & 133 & 8.3 & 5,380 & 21.3 & 2 & 4,380 & 1,090 & 750 & 291 \\
\hline 03069880 & 100 & 7.3 & 75 & 10.5 & 0 & 44 & 29.1 & 2 & 8.94 \\
\hline 383309080021539 & 101 & 8 & 176 & 17.2 & 0.7 & 102 & 76 & 3 & 25.7 \\
\hline 383936079585339 & 104 & 7.7 & 105 & 22.1 & 0.2 & 73 & 47 & 5 & 15.2 \\
\hline 384352080084839 & 104 & 8.2 & 256 & 22.6 & 0.5 & 165 & 30.8 & -- & 9.63 \\
\hline 384401079584939 & 98 & 7.5 & 81 & 22.4 & 2 & 55 & 38.5 & 7 & 12.6 \\
\hline 384440080140939 & 103 & 8.6 & 113 & 20.6 & 0.8 & 66 & 25.2 & -- & 7.68 \\
\hline 384517080093039 & 98 & 7.2 & 57 & 16.6 & 0.3 & 37 & 20.2 & 5 & 5.51 \\
\hline 385015079523339 & 87 & 7.2 & 102 & 20.5 & 0.6 & 77 & 42.2 & 2 & 13.3 \\
\hline 385207080272939 & 55 & 7 & 200 & 22.8 & 3.4 & 113 & 68 & 10 & 21 \\
\hline 385232080155239 & 98 & 7.4 & 101 & 17.2 & 0.8 & 69 & 40.6 & 10 & 13.2 \\
\hline 385307080175339 & 62 & 7 & 118 & 18.1 & 5.9 & 72 & 47.3 & 4 & 14.6 \\
\hline 385333079384039 & 100 & 7.2 & 56 & 20.1 & 2.1 & 45 & 23.5 & 3 & 7.3 \\
\hline 385342079512439 & 97 & 7.7 & 239 & 23.9 & 0 & 144 & 88.4 & 9 & 28.4 \\
\hline 385346080065239 & 89 & 7.4 & 103 & 20.7 & 0.2 & 60 & 46 & 7 & 15.6 \\
\hline 385750080091039 & 103 & 7.6 & 305 & 20.4 & 2.5 & 195 & 137 & 105 & 28.9 \\
\hline 390134079491139 & 102 & 7.2 & 115 & 28.1 & 6.2 & 63 & 42.5 & 4 & 12.9 \\
\hline 390253080283839 & 90 & 7.8 & 466 & 19.6 & 0.6 & 278 & 189 & 48 & 53.1 \\
\hline 390334080091839 & 108 & 7.6 & 751 & 14.4 & 8.4 & 495 & 386 & 277 & 105 \\
\hline 390520080232239 & 171 & 8.7 & 701 & 25.7 & 4.6 & 486 & 280 & 154 & 74.9 \\
\hline 390627080294039 & 105 & 7.9 & 360 & 23.7 & 6 & 225 & 174 & 65 & 48.1 \\
\hline 390820079304039 & 106 & 8.1 & 165 & 12.5 & 6.8 & 98 & 72.1 & 34 & 21.4 \\
\hline 390853079424839 & 97 & 7.2 & 62 & 16.4 & 0 & 44 & 24 & 6 & 6.63 \\
\hline 390947080154239 & 101 & 8.2 & 1,220 & 20.9 & 10 & 908 & 500 & 256 & 126 \\
\hline 391000079421039 & 94 & 7.2 & 63 & 16.6 & 2.6 & 44 & 24.1 & 4 & 6.5 \\
\hline 391000080220739 & 68 & 7.6 & 557 & 19.6 & 12 & 334 & 230 & 110 & 65 \\
\hline 391023080140539 & 97 & 8 & 769 & 19.3 & 3.6 & 622 & 378 & 252 & 97.1 \\
\hline 391108079354239 & 100 & 7.5 & 68 & 12.1 & 1.8 & 49 & 25.8 & 5 & 7.33 \\
\hline 391212079545339 & 103 & 7.6 & 96 & 10.3 & -- & 64 & 39.7 & 8 & 12.3 \\
\hline 391353080172039 & 104 & 8.1 & 843 & 21.8 & 2.9 & 615 & 453 & 320 & 120 \\
\hline 391605080094739 & 98 & 8 & 1,120 & 19.8 & 1.5 & 872 & 534 & 442 & 145 \\
\hline 391632080292039 & 53 & 7.4 & 378 & 18.4 & 16 & 216 & 150 & 5 & 44.4 \\
\hline 391817080291539 & 102 & 7.9 & 499 & 20.8 & 3.8 & 280 & 151 & 40 & 46.7 \\
\hline 391958079520739 & 93 & 4.8 & 305 & 9.6 & 0.9 & 190 & 106 & 99 & 31.2 \\
\hline 392105079394839 & 100 & 7.6 & 126 & 11.2 & 0.2 & 71 & 52.7 & 14 & 15.6 \\
\hline 392203080243739 & 113 & 8.1 & 1,080 & 23.1 & -- & 744 & 418 & 228 & 125 \\
\hline 392335080114839 & 120 & 8.2 & 285 & 23.2 & 2.7 & 174 & 122 & 56 & 37.7 \\
\hline 392457080192939 & 127 & 8.4 & 1,110 & 25.2 & -- & 762 & 259 & 101 & 69.7 \\
\hline 392947080054139 & 117 & 8.5 & 316 & 25.3 & 0.9 & 192 & 127 & 26 & 40 \\
\hline 393059079483739 & 100 & 7.4 & 611 & 11.5 & 2.4 & 441 & 314 & 261 & 104 \\
\hline 393250080023439 & 113 & 8.6 & 136 & 25.3 & 1.8 & 80 & 53.8 & 11 & 16.9 \\
\hline 393308080100339 & 67 & 7.7 & 1,080 & 19.6 & 18 & 725 & 276 & 92 & 75.2 \\
\hline 393320080212239 & 71 & 7.8 & 366 & 21.9 & 12 & 211 & 95 & -- & 28.8 \\
\hline 393408080045039 & 111 & 8.3 & 4,080 & 21.2 & 1.5 & 3,300 & 889 & 649 & 227 \\
\hline 393838079361239 & 101 & 7.7 & 236 & 9.3 & 1.1 & 139 & 85.6 & 48 & 23.6 \\
\hline 393903079432039 & 113 & 7.9 & 125 & 21.9 & -- & 74 & 37.6 & 14 & 11.8 \\
\hline 394208080180239 & 53 & 7.6 & 435 & 18.9 & 20 & 263 & 121 & -- & 35.1 \\
\hline 394212080152739 & 92 & 8 & 985 & 20.4 & 5.3 & 626 & 193 & 40 & 50.3 \\
\hline 394227080065739 & 110 & 8.3 & 415 & 21.3 & 2 & 242 & 147 & 3 & 43.2 \\
\hline
\end{tabular}


Appendix 2. Data for base-flow samples collected as part of the Marcellus Shale base-line survey, Monongahela River Basin, West Virginia, July-October 2012.-Continued

[CR, Creek; Ck, creek; HWY, highway; WV, West Virginia; BR, bridge; NR, near; FK, Fork; Fk, fork; ST., Saint; RR, railroad; <, less than; mmHg, millimeters of mercury; $\mathrm{mg} / \mathrm{L}$, milligrams per liter; $\mathrm{ft} / \mathrm{s}$, cubic feet per second; ${ }^{\circ} \mathrm{C}$, degrees Celsius; $\mu \mathrm{S} / \mathrm{cm}$, microsiemens per centimeter at $25^{\circ} \mathrm{C} ; \mu \mathrm{g} / \mathrm{L}$, micrograms per liter; wf, filtered water; $\mathrm{cm}$, centimeter; $\mathrm{CaCO}_{3}$, calcium carbonate; --, no data; $\mathrm{R}$, non-detect, result below sample-specific critical level; $\%$, per mil; pCi/L, picocuries per liter; ${ }^{13} \mathrm{C}$, carbon- $13,{ }^{18} \mathrm{O}$, oxygen- $18 ;{ }^{2} \mathrm{H}$, deuterium; ${ }^{34} \mathrm{~S}$, sulfur- $34 ; \mathrm{CH}_{4}$, methane; DIC, dissolved inorganic carbon; $\mathrm{H} 2 \mathrm{O}$, water; $\mathrm{SO} 4$, sulfate]

\begin{tabular}{|c|c|c|c|c|c|c|c|c|c|}
\hline Station number & $\begin{array}{c}\text { Magnesium, } \\
\text { wf, } \\
\text { in } \mathrm{mg} / \mathrm{L}\end{array}$ & $\begin{array}{c}\text { Potassium, } \\
\text { wf, } \\
\text { in } \mathrm{mg} / \mathrm{L}\end{array}$ & $\begin{array}{l}\text { Sodium, } \\
\text { wf, } \\
\text { in } \mathrm{mg} / \mathrm{L}\end{array}$ & $\begin{array}{c}\text { Alkalinity, wf, } \\
\text { inflection point } \\
\text { field titration, } \\
\text { in } \mathrm{mg} / \mathrm{L} \text { as } \mathrm{CaCO}_{3}\end{array}$ & $\begin{array}{l}\text { Bicarbonate, wf, } \\
\text { inflection point } \\
\text { field titration, } \\
\text { in } \mathrm{mg} / \mathrm{L} \\
\end{array}$ & $\begin{array}{c}\text { Bromide, } \\
\text { wf, } \\
\text { in } \mathrm{mg} / \mathrm{L}\end{array}$ & $\begin{array}{c}\text { Carbon dioxide, } \\
\text { water, } \\
\text { in } \mathrm{mg} / \mathrm{L}\end{array}$ & $\begin{array}{c}\text { Carbonate,wf, } \\
\text { inflection point } \\
\text { field titration, } \\
\text { in } \mathrm{mg} / \mathrm{L}\end{array}$ & $\begin{array}{c}\text { Chloride, } \\
\text { wf, } \\
\text { in } \mathrm{mg} / \mathrm{L}\end{array}$ \\
\hline 03050800 & 10 & 1.33 & 3.99 & 0.1 & 0.4 & 0.027 & 2.6 & -- & 5.68 \\
\hline 03062215 & 86.3 & 8.85 & 949 & 337 & 401 & 0.692 & 3.2 & 4.5 & 100 \\
\hline 03069880 & 1.63 & 1.36 & 2.91 & 26.9 & 32.8 & 0.016 & 2.7 & -- & 3.25 \\
\hline 383309080021539 & 2.85 & 1.14 & 6.26 & 73.4 & 88.4 & 0.018 & 1.5 & 0.5 & 6.24 \\
\hline 383936079585339 & 2.17 & 1.08 & 1.93 & 41.7 & 50.8 & 0.021 & 1.6 & 0.1 & 1.61 \\
\hline 384352080084839 & 1.61 & 1.13 & 45 & 83.5 & 101 & 0.024 & 0.9 & 0.6 & 3.73 \\
\hline 384401079584939 & 1.72 & 0.92 & 0.89 & 31.6 & 38.5 & 0.018 & 1.9 & -- & 0.87 \\
\hline 384440080140939 & 1.45 & 0.78 & 14 & 36 & 43.7 & 0.02 & 0.2 & 0.1 & 2.44 \\
\hline 384517080093039 & 1.55 & 0.66 & 2.65 & 14.8 & 18 & 0.025 & 1.8 & -- & 2.21 \\
\hline 385015079523339 & 2.16 & 1.29 & 3.26 & 40 & 48.7 & 0.018 & 5.1 & -- & 3.11 \\
\hline 385207080272939 & 3.74 & 2.76 & 11.9 & 58.1 & 70.9 & 0.083 & 11 & -- & 15.9 \\
\hline 385232080155239 & 1.8 & 1.34 & 3.75 & 30.9 & 37.6 & 0.048 & 2.7 & 0.1 & 6.59 \\
\hline 385307080175339 & 2.63 & 1.76 & 4.37 & 42.9 & 52.2 & 0.031 & 7.7 & -- & 5.69 \\
\hline 385333079384039 & 1.26 & 0.88 & 1.27 & 20 & 24.4 & 0.015 & 2.3 & -- & 1.1 \\
\hline 385342079512439 & 4.2 & 1.93 & 12.7 & 79.2 & 95.7 & 0.04 & 3.3 & 0.4 & 15.4 \\
\hline 385346080065239 & 1.72 & 1.04 & 2.02 & 39.4 & 48 & 0.026 & 3.4 & -- & 2.14 \\
\hline 385750080091039 & 15.6 & 2.18 & 4.24 & 31.8 & 38.6 & 0.03 & 1.5 & 0.1 & 6.13 \\
\hline 390134079491139 & 2.47 & 1.98 & 4.61 & 38.2 & 46.5 & 0.027 & 4.2 & 0.1 & 6.16 \\
\hline 390253080283839 & 13.7 & 4.9 & 25.7 & 141 & 170 & 0.069 & 4.8 & 1.4 & 42.8 \\
\hline 390334080091839 & 29.8 & 3.59 & 22.8 & 109 & 133 & 0.035 & 5.5 & 0.1 & 8.86 \\
\hline 390520080232239 & 22.4 & 3.31 & 50 & 125 & 152 & 0.045 & 0.5 & 0.6 & 5.96 \\
\hline 390627080294039 & 13.1 & 3.85 & 6.25 & 110 & 134 & 0.031 & 2.7 & 0.1 & 3.82 \\
\hline 390820079304039 & 4.49 & 1.6 & 5.04 & 38.4 & 46.7 & 0.026 & 0.6 & 0.1 & 6.79 \\
\hline 390853079424839 & 1.81 & 1.06 & 2.06 & 18.5 & 22.5 & 0.017 & 2 & -- & 1.73 \\
\hline 390947080154239 & 44.9 & 3.93 & 102 & 244 & 286 & 0.039 & 3.3 & 5.1 & 6.94 \\
\hline 391000079421039 & 1.89 & 1.26 & 1.72 & 20 & 24.4 & 0.018 & 2.6 & -- & 1.88 \\
\hline 391000080220739 & 16.3 & 3.55 & 26.7 & 119 & 145 & 0.052 & 6.5 & 0.3 & 40.3 \\
\hline 391023080140539 & 32.8 & 3.1 & 50 & 126 & 154 & 0.038 & 2.7 & -- & 7.29 \\
\hline 391108079354239 & 1.8 & 1.23 & 2.45 & 20.8 & 25.4 & 0.014 & 1.2 & -- & 3.81 \\
\hline 391212079545339 & 2.15 & 1.4 & 3.35 & 31.8 & 38.8 & 0.014 & 1.5 & -- & 4.09 \\
\hline 391353080172039 & 37.2 & 4.33 & 17.6 & 133 & 160 & 0.041 & 2 & 0.9 & 6.39 \\
\hline 391605080094739 & 41.2 & 3.53 & 56.1 & 92 & 111 & 0.038 & 1.7 & 0.4 & 5.39 \\
\hline 391632080292039 & 9.36 & 3.92 & 24.6 & 145 & 174 & 0.035 & 13 & 0.9 & 9.02 \\
\hline 391817080291539 & 8.28 & 5.07 & 41.2 & 111 & 134 & 0.069 & 2.5 & 0.6 & 63.1 \\
\hline 391958079520739 & 6.78 & 2 & 7.5 & 5.8 & 8.3 & 0.018 & 208 & -- & 8.15 \\
\hline 392105079394839 & 3.3 & 1.33 & 4.02 & 39 & 47.6 & 0.019 & 1.8 & -- & 6.06 \\
\hline 392203080243739 & 25 & 4.72 & 93.8 & 190 & 228 & 0.049 & 3.1 & 1.9 & 10.8 \\
\hline 392335080114839 & 6.71 & 2.81 & 8.96 & 65.7 & 79.5 & 0.036 & 0.7 & 0.3 & 11 \\
\hline 392457080192939 & 20.2 & 3.45 & 151 & 158 & 192 & 0.164 & 1.2 & 0.4 & 26.6 \\
\hline 392947080054139 & 6.56 & 2.59 & 16.7 & 103 & 123 & 0.029 & 0.6 & -- & 13.9 \\
\hline 393059079483739 & 13.5 & 5.12 & 8.31 & 53.1 & 64.6 & 0.036 & 4 & -- & 10.7 \\
\hline 393250080023439 & 2.76 & 1.76 & 5.15 & 43.3 & 52.3 & 0.018 & 0.2 & 0.2 & 6.38 \\
\hline 393308080100339 & 21.3 & 3.38 & 134 & 184 & 223 & 0.259 & 7.1 & 0.4 & 41.5 \\
\hline 393320080212239 & 5.55 & 1.88 & 40.5 & 116 & 141 & 0.156 & 4.1 & 0.3 & 21.8 \\
\hline 393408080045039 & 77.4 & 7.05 & 697 & 241 & 290 & 0.459 & 2.2 & 1.8 & 71.2 \\
\hline 393838079361239 & 6.48 & 2.36 & 12.9 & 38 & 46.3 & 0.037 & 1.4 & -- & 17.4 \\
\hline 393903079432039 & 1.93 & 0.9 & 8.29 & 23.4 & 28.4 & 0.022 & 0.6 & -- & 14.2 \\
\hline 394208080180239 & 7.91 & 2.86 & 49.8 & 160 & 194 & 0.051 & 7.7 & 0.6 & 14.4 \\
\hline 394212080152739 & 16.4 & 3.09 & 151 & 154 & 184 & 0.21 & 2.8 & 1.5 & 42 \\
\hline 394227080065739 & 9.46 & 2.82 & 32.2 & 145 & 174 & 0.067 & 1.5 & 0.8 & 14.6 \\
\hline
\end{tabular}


Appendix 2. Data for base-flow samples collected as part of the Marcellus Shale base-line survey, Monongahela River Basin, West Virginia, July-October 2012.-Continued

[CR, Creek; Ck, creek; HWY, highway; WV, West Virginia; BR, bridge; NR, near; FK, Fork; Fk, fork; ST., Saint; RR, railroad; <, less than; mmHg, millimeters of mercury; $\mathrm{mg} / \mathrm{L}$, milligrams per liter; $\mathrm{ft} / \mathrm{s}$, cubic feet per second; ${ }^{\circ} \mathrm{C}$, degrees Celsius; $\mu \mathrm{S} / \mathrm{cm}$, microsiemens per centimeter at $25^{\circ} \mathrm{C} ; \mu \mathrm{g} / \mathrm{L}$, micrograms per liter; wf, filtered water; $\mathrm{cm}$, centimeter; $\mathrm{CaCO}_{3}$, calcium carbonate; --, no data; $\mathrm{R}$, non-detect, result below sample-specific critical level; $\%$, per mil; pCi/L, picocuries per liter; ${ }^{13} \mathrm{C}$, carbon- $13,{ }^{18} \mathrm{O}$, oxygen- $18 ;{ }^{2} \mathrm{H}$, deuterium; ${ }^{34} \mathrm{~S}$, sulfur- $34 ; \mathrm{CH}_{4}$, methane; DIC, dissolved inorganic carbon; $\mathrm{H} 2 \mathrm{O}$, water; $\mathrm{SO} 4$, sulfate]

\begin{tabular}{|c|c|c|c|c|c|c|c|c|c|}
\hline Station number & $\begin{array}{c}\text { Fluoride, } \\
\text { wf, } \\
\text { in } \mathrm{mg} / \mathrm{L}\end{array}$ & $\begin{array}{c}\text { Silica, } \\
\text { wf, } \\
\text { in } \mathrm{mg} / \mathrm{L}\end{array}$ & $\begin{array}{c}\text { Sulfate, } \\
\text { wf, } \\
\text { in } \mathrm{mg} / \mathrm{L}\end{array}$ & $\begin{array}{c}\text { Aluminum, } \\
\text { wf, } \\
\text { in } \mu \mathrm{g} / \mathrm{L}\end{array}$ & $\begin{array}{c}\text { Barium, } \\
\text { wf, } \\
\text { in } \mu g / L\end{array}$ & $\begin{array}{c}\text { Beryllium, } \\
\text { wf, } \\
\text { in } \mu \mathrm{g} / \mathrm{L}\end{array}$ & $\begin{array}{c}\text { Cadmium, } \\
\text { wf, } \\
\text { in } \mu \mathrm{g} / \mathrm{L}\end{array}$ & $\begin{array}{c}\text { Chromium, } \\
\text { wf, } \\
\text { in } \mu \mathrm{g} / \mathrm{L}\end{array}$ & $\begin{array}{c}\text { Cobalt, } \\
\text { wf, } \\
\text { in } \mu \mathrm{g} / \mathrm{L}\end{array}$ \\
\hline 03050800 & $<.04$ & 7.01 & 112 & 99.8 & 51.3 & 0.245 & 0.188 & $<.07$ & 2.9 \\
\hline 03062215 & 0.26 & 10.1 & 2,640 & $<6.6$ & 18.1 & $<.018$ & $<.048$ & $<.21$ & 0.52 \\
\hline 03069880 & $<.04$ & 4.65 & 6.76 & 4.8 & 50.8 & $<.006$ & $<.016$ & $<.07$ & 0.224 \\
\hline 383309080021539 & $<.04$ & 5.5 & 5.52 & $<2.2$ & 49.8 & $<.006$ & $<.016$ & $<.07$ & 0.323 \\
\hline 383936079585339 & $<.04$ & 6.28 & 5.79 & 2.9 & 36.5 & $<.006$ & $<.016$ & $<.07$ & 0.043 \\
\hline 384352080084839 & 0.1 & 3.27 & 34.5 & 19.8 & 43 & $<.006$ & $<.016$ & 0.07 & 0.346 \\
\hline 384401079584939 & $<.04$ & 2.83 & 4.17 & 22.7 & 41.9 & $<.006$ & $<.016$ & $<.07$ & 0.107 \\
\hline 384440080140939 & $<.04$ & 2.22 & 13.3 & 8.7 & 43.4 & 0.006 & $<.016$ & $<.07$ & 0.194 \\
\hline 384517080093039 & $<.04$ & 2.67 & 7.64 & 5.6 & 35.5 & 0.008 & 0.034 & $<.07$ & 0.09 \\
\hline 385015079523339 & $<.04$ & 3.94 & 5.86 & 3.2 & 48 & $<.006$ & $<.016$ & $<.07$ & 0.324 \\
\hline 385207080272939 & $<.04$ & 3.72 & 8.32 & 3.6 & 84.6 & $<.006$ & $<.016$ & $<.07$ & 0.727 \\
\hline 385232080155239 & 0.05 & 3.66 & 5.84 & 38.8 & 74.5 & 0.025 & 0.017 & $<.07$ & 0.524 \\
\hline 385307080175339 & 0.05 & 4.87 & 6.36 & 10.8 & 49.5 & 0.009 & $<.016$ & 0.08 & 0.788 \\
\hline 385333079384039 & $<.04$ & 3 & 3.42 & 9.1 & 37 & 0.006 & 0.017 & $<.07$ & 0.347 \\
\hline 385342079512439 & $<.04$ & 4.45 & 13.5 & 3.9 & 58.7 & $<.006$ & $<.016$ & $<.07$ & 0.507 \\
\hline 385346080065239 & $<.04$ & 2.56 & 6.7 & 8.1 & 67.3 & 0.014 & $<.016$ & $<.07$ & 0.416 \\
\hline 385750080091039 & 0.05 & 4.04 & 101 & 10.5 & 51.7 & 0.007 & $<.016$ & $<.07$ & 0.348 \\
\hline 390134079491139 & $<.04$ & 2.2 & 5.24 & 19.1 & 57.7 & 0.011 & 0.019 & 0.07 & 1.11 \\
\hline 390253080283839 & 0.13 & 3.16 & 40.2 & 2.7 & 71.6 & $<.006$ & $<.016$ & 0.07 & 0.64 \\
\hline 390334080091839 & 0.16 & 1.69 & 280 & 61.9 & 58.5 & 0.012 & 0.067 & $<.07$ & 3.99 \\
\hline 390520080232239 & 0.18 & 3.86 & 220 & 12.2 & 64.9 & $<.006$ & $<.016$ & $<.07$ & 0.224 \\
\hline 390627080294039 & 0.1 & 3.75 & 60.1 & 6.9 & 70.8 & $<.006$ & $<.016$ & $<.07$ & 0.862 \\
\hline 390820079304039 & 0.06 & 2.95 & 26.8 & 35.7 & 35.1 & 0.01 & 0.018 & 0.11 & 1.5 \\
\hline 390853079424839 & $<.04$ & 4.91 & 5.69 & 3.6 & 27.6 & $<.006$ & $<.016$ & $<.07$ & 0.078 \\
\hline 390947080154239 & 0.23 & 4.45 & 433 & 10.2 & 54.8 & $<.006$ & $<.016$ & $<.07$ & 0.337 \\
\hline 391000079421039 & $<.04$ & 4.28 & 5.98 & 5.1 & 30 & $<.006$ & $<.016$ & $<.07$ & 0.08 \\
\hline 391000080220739 & 0.12 & 4.12 & 82.2 & 4.9 & 95 & $<.006$ & $<.016$ & $<.07$ & 0.894 \\
\hline 391023080140539 & 0.14 & 4.58 & 309 & 14.2 & 49 & $<.006$ & $<.016$ & $<.07$ & 0.272 \\
\hline 391108079354239 & $<.04$ & 3.87 & 5.95 & 5 & 32.3 & $<.006$ & $<.016$ & $<.07$ & 0.461 \\
\hline 391212079545339 & $<.04$ & 3.36 & 7.45 & 4.6 & 42.3 & $<.006$ & $<.016$ & $<.07$ & 0.157 \\
\hline 391353080172039 & 0.15 & 4.06 & 301 & 5.6 & 65.9 & $<.006$ & $<.016$ & $<.07$ & 0.578 \\
\hline 391605080094739 & 0.25 & 9.93 & 470 & 41 & 36.7 & $<.006$ & $<.016$ & $<.07$ & 0.753 \\
\hline 391632080292039 & 0.1 & 4.23 & 23 & 11.5 & 98.4 & $<.006$ & $<.016$ & $<.07$ & 0.423 \\
\hline 391817080291539 & 0.14 & 3.06 & 23.7 & 10.8 & 86.5 & 0.039 & 0.053 & 0.1 & 0.435 \\
\hline 391958079520739 & 0.09 & 9.61 & 144 & 4,420 & 47.3 & 1.8 & 0.21 & 0.37 & 20.6 \\
\hline 392105079394839 & $<.04$ & 4.27 & 12.6 & 2.7 & 58.9 & $<.006$ & $<.016$ & $<.07$ & 0.106 \\
\hline 392203080243739 & 0.27 & 6.32 & 363 & 13.1 & 66.2 & $<.006$ & $<.016$ & $<.07$ & 0.341 \\
\hline 392335080114839 & 0.09 & 3.98 & 42 & 8 & 62.2 & $<.006$ & $<.016$ & $<.07$ & 0.327 \\
\hline 392457080192939 & 0.22 & 2.64 & 369 & 7.1 & 67.5 & $<.006$ & $<.016$ & $<.07$ & 0.434 \\
\hline 392947080054139 & 0.11 & 2.91 & 31.1 & 13.9 & 78.7 & $<.006$ & $<.016$ & $<.07$ & 0.548 \\
\hline 393059079483739 & 0.18 & 2.55 & 261 & 4.2 & 37.4 & 0.006 & 0.025 & $<.07$ & 1.01 \\
\hline 393250080023439 & 0.06 & 2.05 & 11.8 & 25 & 56.2 & $<.006$ & $<.016$ & $<.07$ & 0.311 \\
\hline 393308080100339 & 0.2 & 3.65 & 302 & 9.5 & 69.8 & 0.007 & $<.016$ & $<.07$ & 0.681 \\
\hline 393320080212239 & 0.17 & 4.63 & 28.6 & 15.9 & 82.5 & $<.006$ & 0.022 & $<.07$ & 0.483 \\
\hline 393408080045039 & 0.27 & 7.28 & 2,040 & 6.5 & 20.9 & $<.012$ & 0.033 & $<.14$ & 0.401 \\
\hline 393838079361239 & 0.06 & 4.47 & 43.7 & 13 & 48.3 & 0.01 & $<.016$ & $<.07$ & 0.304 \\
\hline 393903079432039 & 0.05 & 2.95 & 12.1 & 23 & 48.9 & 0.012 & 0.017 & $<.07$ & 0.081 \\
\hline 394208080180239 & 0.15 & 3.08 & 41.3 & 11.4 & 83.9 & $<.006$ & $<.016$ & $<.07$ & 0.599 \\
\hline 394212080152739 & 0.17 & 1.68 & 284 & 10.2 & 72.4 & $<.006$ & $<.016$ & $<.07$ & 0.769 \\
\hline 394227080065739 & 0.14 & 4.99 & 43.9 & 8 & 65.1 & $<.006$ & $<.016$ & $<.07$ & 0.172 \\
\hline
\end{tabular}


Appendix 2. Data for base-flow samples collected as part of the Marcellus Shale base-line survey, Monongahela River Basin, West Virginia, July-October 2012.-Continued

[CR, Creek; Ck, creek; HWY, highway; WV, West Virginia; BR, bridge; NR, near; FK, Fork; Fk, fork; ST., Saint; RR, railroad; <, less than; mmHg, millimeters of mercury; $\mathrm{mg} / \mathrm{L}$, milligrams per liter; $\mathrm{ft} 3 / \mathrm{s}$, cubic feet per second; ${ }^{\circ} \mathrm{C}$, degrees Celsius; $\mu \mathrm{S} / \mathrm{cm}$, microsiemens per centimeter at $25^{\circ} \mathrm{C} ; \mu \mathrm{g} / \mathrm{L}$, micrograms per liter; wf, filtered water; $\mathrm{cm}$, centimeter; $\mathrm{CaCO}_{3}$, calcium carbonate; --, no data; $\mathrm{R}$, non-detect, result below sample-specific critical level; $\%$, per mil; pCi/L, picocuries per liter; ${ }^{13} \mathrm{C}$, carbon- $13,{ }^{18} \mathrm{O}$, oxygen- $18 ;{ }^{2} \mathrm{H}$, deuterium; ${ }^{34} \mathrm{~S}$, sulfur- $34 ; \mathrm{CH}_{4}$, methane; DIC, dissolved inorganic carbon; $\mathrm{H} 2 \mathrm{O}$, water; $\mathrm{SO} 4$, sulfate]

\begin{tabular}{|c|c|c|c|c|c|c|c|c|c|}
\hline Station number & $\begin{array}{c}\text { Copper, } \\
\text { wf, } \\
\text { in } \mu g / L\end{array}$ & $\begin{array}{c}\text { Iron, } \\
\text { wf, } \\
\text { in } \mu g / L\end{array}$ & $\begin{array}{c}\text { Lead, } \\
\text { wf, } \\
\text { in } \mu \mathrm{g} / \mathrm{L}\end{array}$ & $\begin{array}{c}\text { Manganese, } \\
\text { wf, } \\
\text { in } \mu \mathrm{g} / \mathrm{L}\end{array}$ & $\begin{array}{c}\text { Molybdenum, } \\
\text { wf, } \\
\text { in } \mu \mathrm{g} / \mathrm{L}\end{array}$ & $\begin{array}{c}\text { Nickel, } \\
\text { wf, } \\
\text { in } \mu g / L\end{array}$ & $\begin{array}{c}\text { Silver, } \\
\text { wf, } \\
\text { in } \mu g / L\end{array}$ & $\begin{array}{c}\text { Strontium, } \\
\text { wf, } \\
\text { in } \mu \mathrm{g} / \mathrm{L}\end{array}$ & $\begin{array}{c}\text { Zinc, } \\
\text { wf, } \\
\text { in } \mu g / L\end{array}$ \\
\hline 03050800 & $<.80$ & 32.6 & $<.025$ & 351 & $<.014$ & 18.5 & $<.005$ & 71.9 & 33.7 \\
\hline 03062215 & $<2.4$ & 10 & $<.075$ & 91.1 & 0.442 & 1.2 & $<.015$ & 4,470 & $<4.2$ \\
\hline 03069880 & $<.80$ & 23.4 & 0.048 & 3.5 & 0.06 & 0.34 & $<.005$ & 39.3 & $<1.4$ \\
\hline 383309080021539 & $<.80$ & 4.9 & $<.025$ & 5.95 & 0.23 & 0.22 & $<.005$ & 75.2 & $<1.4$ \\
\hline 383936079585339 & $<.80$ & $<3.2$ & $<.025$ & 1.66 & 0.077 & 0.14 & $<.005$ & 45.9 & $<1.4$ \\
\hline 384352080084839 & $<.80$ & 87.9 & $<.025$ & 14.8 & 0.222 & 0.43 & $<.005$ & 49.6 & $<1.4$ \\
\hline 384401079584939 & $<.80$ & 66.8 & 0.032 & 12.8 & 0.041 & 0.27 & $<.005$ & 27.1 & $<1.4$ \\
\hline 384440080140939 & $<.80$ & 70.2 & 0.025 & 21.3 & 0.077 & 0.42 & $<.005$ & 28.3 & $<1.4$ \\
\hline 384517080093039 & 0.8 & 11.7 & 0.039 & 6.06 & 0.078 & 0.28 & $<.005$ & 23.6 & $<1.4$ \\
\hline 385015079523339 & $<.80$ & 93.9 & 0.032 & 21.2 & 0.075 & 0.35 & $<.005$ & 43.2 & $<1.4$ \\
\hline 385207080272939 & $<.80$ & 596 & 0.071 & 441 & 0.194 & 0.62 & $<.005$ & 118 & $<1.4$ \\
\hline 385232080155239 & $<.80$ & 158 & 0.048 & 26.8 & 0.098 & 1.1 & $<.005$ & 73.7 & $<1.4$ \\
\hline 385307080175339 & 0.83 & 505 & 0.104 & 155 & 0.137 & 0.75 & $<.005$ & 61.1 & $<1.4$ \\
\hline 385333079384039 & $<.80$ & 72.5 & 0.055 & 22.1 & 0.067 & 0.38 & $<.005$ & 23.8 & $<1.4$ \\
\hline 385342079512439 & $<.80$ & 185 & 0.031 & 37.3 & 1.45 & 0.44 & $<.005$ & 106 & $<1.4$ \\
\hline 385346080065239 & $<.80$ & 177 & 0.044 & 20.3 & 0.039 & 0.75 & $<.005$ & 36.9 & $<1.4$ \\
\hline 385750080091039 & $<.80$ & 59.3 & 0.028 & 24.4 & 0.068 & 0.99 & $<.005$ & 54.9 & $<1.4$ \\
\hline 390134079491139 & 0.8 & 662 & 0.201 & 108 & 0.205 & 0.98 & $<.005$ & 50.9 & $<1.4$ \\
\hline 390253080283839 & 1.4 & 64.8 & 0.051 & 258 & 1.25 & 1.3 & $<.005$ & 215 & $<1.4$ \\
\hline 390334080091839 & 0.85 & 41.7 & $<.025$ & 473 & 0.234 & 5.5 & $<.005$ & 448 & 2.6 \\
\hline 390520080232239 & 0.81 & 13.6 & $<.025$ & 67 & 0.619 & 0.75 & $<.005$ & 494 & $<1.4$ \\
\hline 390627080294039 & 0.84 & 29.6 & 0.06 & 132 & 1.05 & 0.93 & $<.005$ & 197 & $<1.4$ \\
\hline 390820079304039 & $<.80$ & 134 & 0.11 & 18.6 & 0.248 & 1.8 & $<.005$ & 141 & 1.7 \\
\hline 390853079424839 & 0.86 & 12.6 & 0.028 & 1.78 & 0.035 & 0.14 & $<.005$ & 26.8 & $<1.4$ \\
\hline 390947080154239 & $<.80$ & 9.3 & $<.025$ & 64 & 0.843 & 1.1 & $<.005$ & 960 & $<1.4$ \\
\hline 391000079421039 & $<.80$ & 10.4 & $<.025$ & 2 & 0.035 & 0.2 & $<.005$ & 25.5 & $<1.4$ \\
\hline 391000080220739 & $<.80$ & 37.5 & 0.056 & 349 & 1.04 & 1 & $<.005$ & 228 & $<1.4$ \\
\hline 391023080140539 & $<.80$ & 18.8 & $<.025$ & 45.1 & 0.466 & 0.96 & $<.005$ & 633 & $<1.4$ \\
\hline 391108079354239 & $<.80$ & 9.9 & 0.048 & 4.43 & 0.039 & 0.27 & $<.005$ & 28.8 & $<1.4$ \\
\hline 391212079545339 & $<.80$ & 98.9 & $<.025$ & 5.54 & 0.169 & 0.4 & $<.005$ & 43.7 & $<1.4$ \\
\hline 391353080172039 & 0.87 & 12.3 & $<.025$ & 50.5 & 0.901 & 1.3 & $<.005$ & 568 & $<1.4$ \\
\hline 391605080094739 & $<.80$ & 5.7 & $<.025$ & 124 & 0.259 & 2.6 & $<.005$ & 971 & $<1.4$ \\
\hline 391632080292039 & $<.80$ & 45.8 & 0.065 & 278 & 1.4 & 0.64 & $<.005$ & 253 & $<1.4$ \\
\hline 391817080291539 & 1.8 & 32.6 & 0.13 & 45.5 & 1.06 & 0.94 & 0.037 & 245 & $<1.4$ \\
\hline 391958079520739 & 3.7 & 1,040 & 0.387 & 401 & 0.019 & 34 & $<.005$ & 149 & 85.4 \\
\hline 392105079394839 & $<.80$ & 5 & $<.025$ & 3.09 & 0.099 & 0.25 & $<.005$ & 86.8 & $<1.4$ \\
\hline 392203080243739 & $<.80$ & 6.6 & $<.025$ & 83.4 & 0.64 & 1.1 & $<.005$ & 1,720 & $<1.4$ \\
\hline 392335080114839 & 1 & 16 & 0.031 & 14 & 0.787 & 0.77 & $<.005$ & 117 & $<1.4$ \\
\hline 392457080192939 & $<.80$ & 8.8 & $<.025$ & 21.8 & 1.03 & 1.6 & $<.005$ & 930 & $<1.4$ \\
\hline 392947080054139 & 1.1 & 31.5 & 0.06 & 11.4 & 0.804 & 0.87 & $<.005$ & 152 & $<1.4$ \\
\hline 393059079483739 & $<.80$ & 32.9 & $<.025$ & 174 & 0.131 & 2.6 & $<.005$ & 278 & 2.3 \\
\hline 393250080023439 & 0.8 & 57.9 & 0.042 & 13.4 & 0.265 & 0.72 & $<.005$ & 65 & $<1.4$ \\
\hline 393308080100339 & 0.8 & 19.4 & 0.044 & 383 & 2 & 0.99 & $<.005$ & 689 & $<1.4$ \\
\hline 393320080212239 & 0.99 & 89.8 & 0.111 & 45.7 & 1.4 & 0.5 & $<.005$ & 195 & $<1.4$ \\
\hline 393408080045039 & $<1.6$ & 16.7 & $<.050$ & 49.6 & 0.548 & 1.1 & $<.010$ & 3,210 & $<2.8$ \\
\hline 393838079361239 & $<.80$ & 150 & 1.21 & 18.9 & 0.107 & 1.6 & $<.005$ & 66.8 & $<1.4$ \\
\hline 393903079432039 & $<.80$ & 29.5 & $<.025$ & 19.7 & 0.109 & 0.66 & $<.005$ & 31.2 & $<1.4$ \\
\hline 394208080180239 & 0.81 & 88.9 & 0.11 & 240 & 1.35 & 0.63 & $<.005$ & 254 & $<1.4$ \\
\hline 394212080152739 & 1.1 & 43.7 & 0.062 & 50.2 & 2.21 & 2.5 & $<.005$ & 400 & $<1.4$ \\
\hline 394227080065739 & $<.80$ & 22.9 & $<.025$ & 15.8 & 0.787 & 0.47 & $<.005$ & 228 & $<1.4$ \\
\hline
\end{tabular}


Appendix 2. Data for base-flow samples collected as part of the Marcellus Shale base-line survey, Monongahela River Basin, West Virginia, July-October 2012.-Continued

[CR, Creek; Ck, creek; HWY, highway; WV, West Virginia; BR, bridge; NR, near; FK, Fork; Fk, fork; ST., Saint; RR, railroad; <, less than; mmHg, millimeters of mercury; $\mathrm{mg} / \mathrm{L}$, milligrams per liter; $\mathrm{ft} / \mathrm{s}$, cubic feet per second; ${ }^{\circ} \mathrm{C}$, degrees Celsius; $\mu \mathrm{S} / \mathrm{cm}$, microsiemens per centimeter at $25^{\circ} \mathrm{C} ; \mu \mathrm{g} / \mathrm{L}$, micrograms per liter; wf, filtered water; $\mathrm{cm}$, centimeter; $\mathrm{CaCO}_{3}$, calcium carbonate; --, no data; $\mathrm{R}$, non-detect, result below sample-specific critical level; $\%$, per mil; pCi/L, picocuries per liter; ${ }^{13} \mathrm{C}$, carbon- $13,{ }^{18} \mathrm{O}$, oxygen- $18 ;{ }^{2} \mathrm{H}$, deuterium; ${ }^{34} \mathrm{~S}$, sulfur- $34 ; \mathrm{CH}_{4}$, methane; DIC, dissolved inorganic carbon; $\mathrm{H} 2 \mathrm{O}$, water; $\mathrm{SO} 4$, sulfate]

\begin{tabular}{|c|c|c|c|c|c|c|c|c|c|}
\hline Station number & $\begin{array}{c}\text { Antimony, } \\
\text { wf, } \\
\text { in } \mu \mathrm{g} / \mathrm{L}\end{array}$ & $\begin{array}{c}\text { Arsenic, } \\
\text { wf, } \\
\text { in } \mu \mathrm{g} / \mathrm{L}\end{array}$ & $\begin{array}{c}\text { Boron, } \\
\text { wf, } \\
\text { in } \mu \mathrm{g} / \mathrm{L}\end{array}$ & $\begin{array}{c}\text { Selenium, } \\
\text { wf, } \\
\text { in } \mu \mathrm{g} / \mathrm{L}\end{array}$ & $\begin{array}{c}\text { Alpha activity, } \\
\text { wf, Thorium-230, } \\
\text { in } \mathrm{pCi} / \mathrm{L}\end{array}$ & $\begin{array}{c}\text { Gross beta, } \\
\text { wf,Cesium-137 } \\
\text { in } \mathrm{pCi} / \mathrm{L}\end{array}$ & $\begin{array}{c}\text { Radium-224, } \\
\text { wf } \\
\text { in pCi/L }\end{array}$ & $\begin{array}{c}\text { Radium-226, } \\
\text { wf, } \\
\text { in pCi/L }\end{array}$ & $\begin{array}{c}\text { Radium-228, } \\
\text { wf, } \\
\text { in pCi/L }\end{array}$ \\
\hline 03050800 & $<.027$ & 0.07 & 13 & 0.57 & 0.7 & 2 & 0.52 & R.10 & 0.29 \\
\hline 03062215 & $<.081$ & 0.37 & 312 & 0.2 & $\mathrm{R} 1$ & 7.4 & R. 00 & R.00 & -- \\
\hline 03069880 & 0.051 & 0.2 & 13 & $<.03$ & R-. 2 & 1.4 & R.14 & R.08 & -- \\
\hline 383309080021539 & 0.075 & 0.33 & 10 & 0.04 & R.2 & 1 & R.07 & R.037 & -- \\
\hline 383936079585339 & $<.027$ & 0.22 & 10 & 0.04 & R-.04 & 0.6 & R.06 & $\mathrm{R}-.05$ & -- \\
\hline 384352080084839 & 0.04 & 0.2 & 27 & 0.08 & 0.9 & 1.5 & 0.18 & R.09 & R.16 \\
\hline 384401079584939 & 0.035 & 0.16 & 8 & 0.03 & R.03 & 1.4 & R.00 & 0.09 & -- \\
\hline 384440080140939 & 0.053 & 0.13 & 14 & 0.07 & 0.4 & 1.4 & R.07 & R.04 & -- \\
\hline 384517080093039 & 0.031 & 0.06 & -- & 0.06 & R-. 1 & 1.1 & R.08 & 0.15 & -- \\
\hline 385015079523339 & 0.066 & 0.35 & 14 & 0.03 & R.0 & 1.9 & R.07 & R.05 & -- \\
\hline 385207080272939 & 0.086 & 0.54 & 18 & 0.11 & R-.29 & 2.7 & R-..06 & R-. 10 & -- \\
\hline 385232080155239 & 0.07 & 0.18 & 11 & 0.08 & 0.5 & 1.2 & R-. 16 & R.00 & -- \\
\hline 385307080175339 & 0.108 & 0.58 & 15 & 0.11 & R.1 & 1.7 & R.00 & R.13 & -- \\
\hline 385333079384039 & 0.069 & 0.34 & 7 & 0.04 & R.3 & 1.4 & R.00 & R. 10 & -- \\
\hline 385342079512439 & 0.124 & 0.63 & 24 & 0.15 & 0.7 & 2.2 & R-. .18 & R.05 & -- \\
\hline 385346080065239 & 0.043 & 0.16 & 9 & 0.07 & 0.4 & 1.4 & R.09 & 0.26 & -- \\
\hline 385750080091039 & 0.067 & 0.18 & 13 & 0.12 & R.3 & 2.5 & R-. .08 & R.00 & -- \\
\hline 390134079491139 & 0.14 & 1.1 & 22 & 0.1 & R.3 & 2.1 & R-. 14 & R.06 & -- \\
\hline 390253080283839 & 0.144 & 0.97 & 42 & 0.18 & R.6 & 3.7 & R.12 & R. 10 & -- \\
\hline 390334080091839 & 0.112 & 0.24 & 34 & 0.23 & R.3 & 3.1 & R.18 & R.00 & -- \\
\hline 390520080232239 & 0.103 & 0.71 & 35 & 0.22 & 2 & 3.4 & R.00 & R.12 & -- \\
\hline 390627080294039 & 0.198 & 0.83 & 23 & 0.19 & R.0 & 3.8 & R.11 & R.00 & -- \\
\hline 390820079304039 & 0.139 & 0.21 & 19 & 0.26 & 0.8 & 1.8 & R.11 & R. 00 & -- \\
\hline 390853079424839 & $<.027$ & 0.19 & 9 & $<.03$ & $\mathrm{R}-.09$ & 0.9 & R-..06 & R.14 & -- \\
\hline 390947080154239 & 0.086 & 0.57 & 54 & 0.31 & $\mathrm{R} 1.1$ & 3.6 & R.08 & R-. .08 & -- \\
\hline 391000079421039 & 0.047 & 0.23 & 11 & $<.03$ & R-..33 & 1.2 & R-. .05 & R.00 & -- \\
\hline 391000080220739 & 0.218 & 0.83 & 32 & 0.16 & R.1 & 3.7 & R.00 & R-.06 & -- \\
\hline 391023080140539 & 0.067 & 0.28 & 38 & 0.15 & 1.1 & 3.3 & 0.8 & 3 & R.00 \\
\hline 391108079354239 & 0.053 & 0.2 & 9 & $<.03$ & 0.4 & R.7 & R.00 & R.05 & -- \\
\hline 391212079545339 & 0.038 & 0.16 & 10 & 0.06 & R-. 1 & R.3 & R.05 & R.038 & -- \\
\hline 391353080172039 & 0.151 & 0.63 & 35 & 0.2 & 2.6 & 3.9 & R. 00 & R-.05 & -- \\
\hline 391605080094739 & 0.077 & 0.24 & 58 & 0.14 & R.9 & 3.8 & R.00 & R.10 & -- \\
\hline 391632080292039 & 0.118 & 0.96 & 39 & 0.16 & R.7 & 3.1 & R.22 & R.12 & -- \\
\hline 391817080291539 & 0.285 & 1.4 & 65 & 0.49 & R-. 4 & 3.4 & R.06 & R.02 & -- \\
\hline 391958079520739 & $<.027$ & 0.25 & 14 & 0.08 & 0.8 & 1.6 & 0.66 & 0.25 & R.08 \\
\hline 392105079394839 & 0.079 & 0.14 & 18 & $<.03$ & 0.5 & 1 & R.00 & R.02 & -- \\
\hline 392203080243739 & 0.071 & 0.26 & 79 & 0.1 & 1.9 & 4.3 & R.3 & R-. 15 & -- \\
\hline 392335080114839 & 0.106 & 0.51 & 26 & 0.13 & R.1 & 2.4 & R-.09 & 0.13 & -- \\
\hline 392457080192939 & 0.11 & 0.29 & 57 & 0.16 & R.2 & 3.7 & 0.13 & 0.11 & R.07 \\
\hline 392947080054139 & 0.134 & 0.51 & 39 & 0.12 & 0.6 & 2.8 & R.00 & 0.11 & -- \\
\hline 393059079483739 & 0.072 & 0.22 & 25 & 0.09 & R-. 7 & 5.1 & R-..06 & R.05 & -- \\
\hline 393250080023439 & 0.083 & 0.29 & 19 & 0.11 & R.4 & 2.1 & R.11 & 0.07 & -- \\
\hline 393308080100339 & 0.343 & 0.65 & 106 & 0.22 & 2 & 3.6 & R.00 & R.02 & -- \\
\hline 393320080212239 & 0.136 & 0.92 & 44 & 0.13 & R.5 & 2.2 & R-..02 & 0.07 & -- \\
\hline 393408080045039 & 0.072 & 0.35 & 217 & 0.15 & $\mathrm{R}-4$ & 6.1 & R.00 & 0.16 & -- \\
\hline 393838079361239 & 0.054 & 0.12 & 17 & 0.08 & R-.1 & 2.2 & $\mathrm{R}-.20$ & R.04 & -- \\
\hline 393903079432039 & 0.033 & 0.14 & 15 & 0.06 & 0.6 & 1.3 & 0.28 & 0.11 & 0.41 \\
\hline 394208080180239 & 0.146 & 1.3 & 49 & 0.2 & 0.8 & 2.4 & R.04 & R.06 & -- \\
\hline 394212080152739 & 0.165 & 0.81 & 81 & 0.22 & $\mathrm{R} 1$ & 2.6 & R.13 & R.02 & -- \\
\hline 394227080065739 & 0.093 & 0.51 & 38 & 0.14 & 1.2 & 3.1 & 0.12 & 0.08 & R.05 \\
\hline
\end{tabular}


Appendix 2. Data for base-flow samples collected as part of the Marcellus Shale base-line survey, Monongahela River Basin, West Virginia, July-October 2012.-Continued

[CR, Creek; Ck, creek; HWY, highway; WV, West Virginia; BR, bridge; NR, near; FK, Fork; Fk, fork; ST., Saint; RR, railroad; <, less than; mmHg, millimeters of mercury; $\mathrm{mg} / \mathrm{L}$, milligrams per liter; $\mathrm{ft} 3 / \mathrm{s}$, cubic feet per second; ${ }^{\circ} \mathrm{C}$, degrees Celsius; $\mu \mathrm{S} / \mathrm{cm}$, microsiemens per centimeter at $25^{\circ} \mathrm{C} ; \mu \mathrm{g} / \mathrm{L}$, micrograms per liter; wf, filtered water; $\mathrm{cm}$, centimeter; $\mathrm{CaCO}_{3}$, calcium carbonate; --, no data; $\mathrm{R}$, non-detect, result below sample-specific critical level; $\%$, per mil; pCi/L, picocuries per liter; ${ }^{13} \mathrm{C}$, carbon- $13,{ }^{18} \mathrm{O}$, oxygen- $18 ;{ }^{2} \mathrm{H}$, deuterium; ${ }^{34} \mathrm{~S}$, sulfur- $34 ; \mathrm{CH}_{4}$, methane; DIC, dissolved inorganic carbon; $\mathrm{H} 2 \mathrm{O}$, water; $\mathrm{SO} 4$, sulfate]

\begin{tabular}{|c|c|c|c|c|c|c|c|c|c|}
\hline Station number & $\begin{array}{c}\text { Uranium, } \\
\text { wf, } \\
\text { in } \mu \mathrm{g} / \mathrm{L}\end{array}$ & $\begin{array}{c}\text { Uranium-234, } \\
\text { wf, } \\
\text { in pCi/L }\end{array}$ & $\begin{array}{c}\text { Uranium-235, } \\
\text { wf, } \\
\text { in } \mathrm{pCi} / \mathrm{L}\end{array}$ & $\begin{array}{c}\text { Uranium-238, } \\
\text { wf, } \\
\text { in pCi/L }\end{array}$ & $\begin{array}{l}{ }^{18} \mathbf{O}_{\text {s04, }} \\
\text { in } \% 0\end{array}$ & $\begin{array}{l}{ }^{34} \mathrm{~S}_{\mathrm{SO}^{\prime}} \\
\text { in } \% 0\end{array}$ & $\begin{array}{l}{ }^{13} C_{D I C} \\
\text { in } \% 0\end{array}$ & $\begin{array}{l}{ }^{2} \mathbf{H}_{\mathrm{H} 2 \mathrm{O}^{\prime}} \\
\text { in } \% 0\end{array}$ & $\begin{array}{l}{ }^{18} \mathrm{O}_{\mathrm{H} 2 \mathrm{O}^{\prime}} \\
\text { in } \% 0\end{array}$ \\
\hline 03050800 & 0.011 & R.000 & R.005 & R.000 & -6.4 & -0.9 & -- & -51.50 & -9.32 \\
\hline 03062215 & 0.51 & 0.26 & R-.008 & 0.18 & 5.7 & 12.1 & -8.80 & -- & -8.15 \\
\hline 03069880 & 0.006 & -- & -- & -- & 4.5 & 1.4 & -9.46 & -46.30 & -8.90 \\
\hline 383309080021539 & 0.079 & R.009 & R.011 & R.000 & 4.4 & 1.0 & -10.34 & -54.80 & -8.56 \\
\hline 383936079585339 & 0.014 & R.002 & R.000 & R.000 & -- & -- & -11.23 & -50.40 & -7.77 \\
\hline 384352080084839 & 0.066 & 0.036 & R-.005 & 0.023 & 0.2 & 2.4 & -6.80 & -55.10 & -9.15 \\
\hline 384401079584939 & 0.011 & R.006 & R.004 & R.009 & 5.5 & 4.7 & -7.72 & -50.50 & -8.46 \\
\hline 384440080140939 & 0.006 & -- & -- & -- & 3.5 & 3.5 & -7.85 & -52.60 & -7.80 \\
\hline 384517080093039 & $<.004$ & -- & -- & -- & 2.9 & 5.1 & -7.18 & -54.80 & -8.29 \\
\hline 385015079523339 & 0.01 & R-.009 & 0.011 & R-.009 & 4.6 & 0.9 & -12.09 & -53.80 & -8.83 \\
\hline 385207080272939 & 0.043 & R.014 & R.000 & R.010 & 6.6 & 3.9 & -11.90 & -36.70 & -6.56 \\
\hline 385232080155239 & 0.013 & R.010 & R.000 & 0.02 & 3.3 & 1.9 & -9.71 & -45.80 & -7.51 \\
\hline 385307080175339 & 0.023 & R.007 & R-.009 & R.004 & -- & 3.6 & -12.77 & -42.30 & -6.74 \\
\hline 385333079384039 & 0.007 & -- & -- & -- & 3.9 & 3.9 & -9.13 & -45.00 & -9.46 \\
\hline 385342079512439 & 0.182 & 0.11 & R.012 & 0.058 & 2.2 & -7.6 & -10.81 & -45.00 & -8.72 \\
\hline 385346080065239 & 0.012 & R.006 & R.004 & 0.03 & 4.1 & 2.9 & -9.37 & -51.30 & -7.70 \\
\hline 385750080091039 & 0.033 & R-.009 & R.000 & 0.028 & -1.1 & -6.0 & -8.48 & -50.40 & -8.22 \\
\hline 390134079491139 & 0.024 & $\mathrm{R}-.017$ & 0.01 & R-.009 & 5.3 & 2.2 & -11.66 & -39.70 & -7.17 \\
\hline 390253080283839 & 0.651 & 0.27 & R.01 & 0.2 & 10.6 & 6.5 & -11.80 & -- & -4.25 \\
\hline 390334080091839 & 0.369 & 0.17 & 0.013 & 0.16 & 1.6 & 1.5 & -8.73 & -48.00 & -7.78 \\
\hline 390520080232239 & 0.785 & 0.34 & 0.021 & 0.26 & -1.1 & 1.8 & -7.89 & -36.53 & -7.14 \\
\hline 390627080294039 & 0.7 & 0.4 & R-.005 & 0.24 & 3.8 & -3.4 & -11.33 & -25.90 & -4.45 \\
\hline 390820079304039 & 0.043 & 0.063 & R.000 & 0.054 & -0.2 & -0.8 & -6.32 & -47.50 & -8.59 \\
\hline 390853079424839 & $<.004$ & -- & -- & -- & 3.9 & 3.8 & -10.13 & -48.60 & -8.61 \\
\hline 390947080154239 & 1.39 & 0.55 & 0.03 & 0.39 & -1.9 & 0.1 & -5.87 & -49.90 & -7.67 \\
\hline 391000079421039 & $<.004$ & -- & -- & -- & 4.1 & 3.6 & -9.30 & -48.40 & -8.43 \\
\hline 391000080220739 & 0.816 & 0.33 & 0.01 & 0.19 & 1.1 & 1.2 & -12.36 & -38.00 & -5.71 \\
\hline 391023080140539 & 0.83 & 0.31 & R.000 & 0.27 & -1.1 & 0.3 & -9.19 & -50.70 & -7.13 \\
\hline 391108079354239 & $<.004$ & -- & -- & -- & 3.2 & 2.0 & -8.16 & -52.80 & -8.75 \\
\hline 391212079545339 & 0.023 & R.000 & R-.003 & R.003 & 4.5 & & -7.48 & -50.10 & -8.51 \\
\hline 391353080172039 & 1.3 & 0.59 & 0.027 & 0.44 & 4.0 & -1.3 & -10.84 & -33.60 & -6.22 \\
\hline 391605080094739 & 0.447 & 0.2 & R-.006 & 0.15 & -2.5 & 0.3 & -6.51 & -46.90 & -8.43 \\
\hline 391632080292039 & 0.676 & 0.28 & R.000 & 0.17 & 2.4 & -2.1 & -12.77 & -41.40 & -6.42 \\
\hline 391817080291539 & 0.582 & 0.2 & R.000 & 0.18 & 6.2 & 2.0 & -10.96 & -36.60 & -6.11 \\
\hline 391958079520739 & 0.255 & 0.09 & $\mathrm{R}-.006$ & 0.1 & -3.3 & 0.4 & -- & -48.90 & -8.55 \\
\hline 392105079394839 & 0.005 & -- & -- & -- & 3.7 & 1.3 & -9.92 & -49.83 & -8.62 \\
\hline 392203080243739 & 0.521 & 0.21 & 0.017 & 0.18 & 2.1 & 3.2 & -10.88 & -47.00 & -7.35 \\
\hline 392335080114839 & 0.22 & 0.14 & R-.004 & 0.077 & 6.4 & -4.7 & -11.16 & -34.00 & -5.52 \\
\hline 392457080192939 & 0.512 & 0.17 & R.020 & 0.14 & 1.9 & -4.9 & -9.74 & -42.10 & -7.28 \\
\hline 392947080054139 & 0.432 & 0.17 & R.000 & 0.13 & 3.6 & -3.4 & -10.00 & -38.10 & -6.01 \\
\hline 393059079483739 & 0.058 & 0.042 & R.008 & 0.04 & 1.8 & 4.0 & -24.61 & -40.16 & -6.70 \\
\hline 393250080023439 & 0.064 & 0.023 & R.000 & 0.011 & 7.4 & 2.1 & -10.07 & -24.40 & -5.78 \\
\hline 393308080100339 & 0.773 & 0.35 & R.000 & 0.32 & 6.6 & 13.4 & -12.00 & -46.80 & -6.89 \\
\hline 393320080212239 & 0.365 & 0.12 & $\mathrm{R}-.010$ & 0.1 & 6.4 & 2.6 & -14.14 & -43.10 & -7.12 \\
\hline 393408080045039 & 0.452 & 0.16 & R-.005 & 0.12 & 4.9 & 11.5 & -9.52 & -- & -7.73 \\
\hline 393838079361239 & 0.046 & R.000 & R-..004 & 0.02 & 1.1 & -3.6 & -24.05 & -59.80 & -8.75 \\
\hline 393903079432039 & 0.012 & $\mathrm{R}-.020$ & R-.005 & R.012 & 4.0 & 1.1 & -12.22 & -42.40 & -7.50 \\
\hline 394208080180239 & 0.602 & 0.27 & R.000 & 0.18 & 4.8 & 5.3 & -14.57 & -48.70 & -7.36 \\
\hline 394212080152739 & 0.779 & 0.31 & 0.017 & 0.25 & 5.3 & 11.8 & -11.60 & -47.80 & -7.20 \\
\hline 394227080065739 & 0.547 & 0.3 & R.000 & 0.17 & 4.4 & 4.0 & -11.68 & -48.90 & -7.52 \\
\hline
\end{tabular}


For additional information call or write to:

Director, U.S. Geological Survey

West Virginia Water Science Center

11 Dunbar Street, Charleston, WV 25301

(304) $347-5130$

http://wv.usgs.gov 
